$$
\text { UNIVERSIDADE DE SÃO PAULO }
$$

FACULDADE DE FILOSOFIA, LETRAS E CIÊNCIAS HUMANAS

DEPARTAMENTO DE TEORIA LITERÁRIA E LITERATURA COMPARADA

\title{
A APREENSÃO DO DESCONCERTO: \\ SUBJETIVIDADE E NAÇÃO NA POESIA DE MÁRIO DE ANDRADE
}

LEANDRO PASINI

SÃO PAULO 
UNIVERSIDADE DE SÃO PAULO

FACULDADE DE FILOSOFIA, LETRAS E CIÊNCIAS HUMANAS

DEPARTAMENTO DE TEORIA LITERÁRIA E LITERATURA COMPARADA

\section{A APREENSÃO DO DESCONCERTO: \\ SUBJETIVIDADE E NAÇÃO NA POESIA DE MÁRIO DE ANDRADE}

LEANDRO PASINI

Tese de Doutoramento em Teoria Literária e Literatura Comparada apresentada à Faculdade de Filosofia, Letras e Ciências Humanas da Universidade de São Paulo.

ORIENTADOR: PROF. DR. JORGE MATTOS BRITO DE ALMEIDA 
Banca examinadora 
para Lili, dont tout ce que l'on aime est digne d'être aimé 


\section{AGRADECIMENTOS}

Em primeiro lugar à minha família, e sobretudo ao meu pai, cujo apoio e exemplo me acompanharam o tempo todo.

Ao meu orientador Jorge de Almeida, por me propiciar um diálogo franco, o apoio necessário e muita liberdade.

Aos funcionários do Departamento de Teoria Literária e Literatura Comprada, especialmente ao Luiz de Mattos Alves, que sempre presta ajuda inestimável.

Ao meu grande amigo Fábio Borges, com quem discuti assuntos amazônicos.

Aos amigos de ideias, debates e leituras Gabriela Siqueira Bitencourt, Daniel Garroux, César Takemoto, Maíra Marquez, Ton Lopes e Alice Ricci. Destes agradeço especialmente à Gabriela, eterna colega de orientação, pela companhia sempre inteligente e compreensiva, e que se tornou uma espécie de irmã mais nova.

À professora Iumna M. Simon, pelo interesse intempestivo em meu texto de qualificação e pela presença e generosidade nos momentos finais da tese.

Ao meu professor José Antônio Pasta, por sua atenção terna e paciente, por ser um intelectual inconformista e irredutível, por ter me demonstrado o interesse e a importância da literatura brasileira, e por ter se tornado para mim, para usar uma expressão que lhe é cara, um indivíduo que leva em si uma totalidade.

Ao pequeno Léo, filho por afinidade eletiva, que me lembrou que a poesia é a descoberta das coisas que eu nunca vi.

À minha namorada Eliane Paradela Arakaki, a quem esta tese é dedicada, que leu e revisou cada versão deste texto, discutiu comigo cada linha, participando assim de todas as suas etapas de elaboração, que compartilhou comigo cada momento bom e ruim que a grande solidão de fazer uma tese traz consigo, e que, sem se dar conta disso, atenuou o máximo que pôde a minha árida tendência abstrativa. 
Esta pesquisa contou com o apoio de uma bolsa de estudos do Conselho Nacional de Desenvolvimento Científico e Tecnológico - CNPq. 


\section{RESUMO}

A obra poética de Mário de Andrade, compreendida em seu conjunto, apresenta duas referências constantes, verdadeiras obsessões do poeta: o Brasil e a própria subjetividade. Esta tese busca interpretar como essas duas obsessões se entrelaçam, ou seja, como a subjetividade lírica de Mário de Andrade busca constantemente expressarse com traços da nacionalidade, levando em conta que toda a sua poesia se desenvolve na busca de resolver esteticamente - e mesmo extraesteticamente - essa questão. Tendo em vista que os descompassos dessa relação entre eu e Brasil perpassam todas as fases de sua poesia, com diferentes configurações, a relação entre o Brasil e a subjetividade lírica é uma chave para a abordagem de diversos temas de sua obra poética, como o amor, a religiosidade, o popular, o engajamento, entre outros. Isso também exige uma reavaliação da posição e do significado da lírica de Mário de Andrade no Movimento Modernista brasileiro e no contexto do Modernismo internacional.

Palavras-chave: Mário de Andrade, Poesia Brasileira, Modernismo, Subjetividade Lírica, Formação. 


\begin{abstract}
The poetical works of Mario de Andrade, approached as a whole, present two constant signs, true obsessions of the poet: Brazil and his own subjectivity. This work searches to explain the way these two obsessions intertwine themselves, that is to say, the way the lyrical subjectivity of Mario de Andrade constantly tries to be expressed by features of nationality, taking into account that all his poetry develops by striving aesthetically and even extraesthetically - to solve this problem. To bear in mind that the disparities in the relation between the I and Brazil cover all the stages of his poetry, with different configurations, therefore this relation is a key to comprehend many of the themes of his poetry, like love, religiousness, the popular culture, the engagement, among others. This view also claims a new evaluation of the place and the meaning of Mario de Andrade's lyrical poetry within the Brazilian Modernist Movement and in the context of the international Modernism.
\end{abstract}

Key words: Mario de Andrade, Brazilian Poetry, Modernism, Lyrical Subjectivity, Bildung. 


\section{SUMÁRIO}

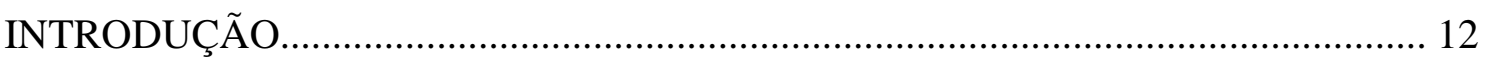

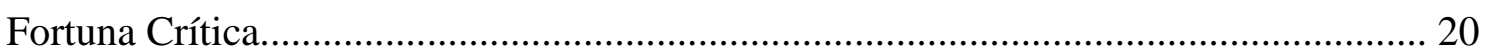

Modernismo, Formação, Lírica e Sociedade.............................................................. 38

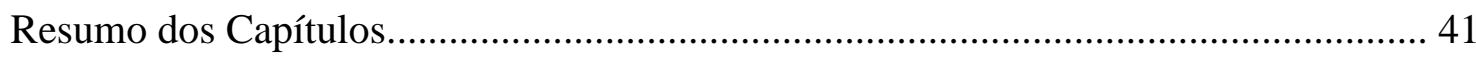

CAPÍTULO I - UMA POSITIVIDADE AGÔNICA................................................. 44

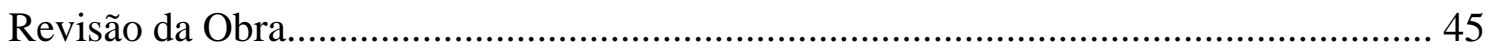

“A Meditação sobre o Tietê" e "O Movimento Modernista".......................................... 50

Os Dois Rios ou Empenho Civilizatório e Mana Brasílico............................................ 54

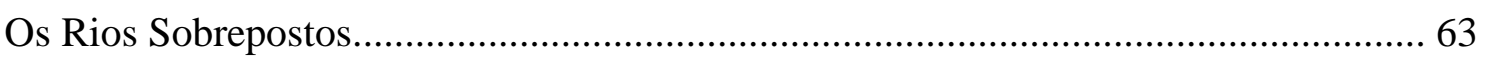

\section{CAPÍTULO II - VERDADE PSICOLÓGICA OU}

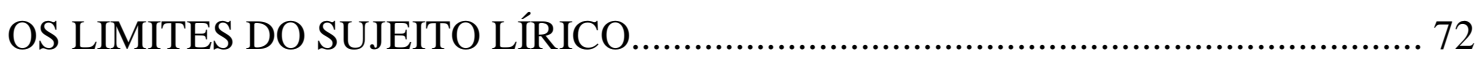

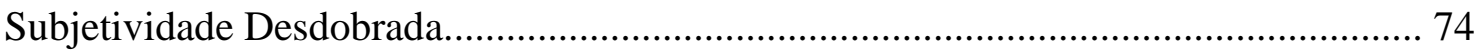

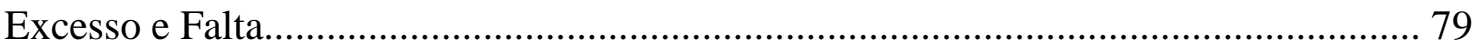

Subjetividade Lírica Moderna e Má-Formação do Eu................................................ 81

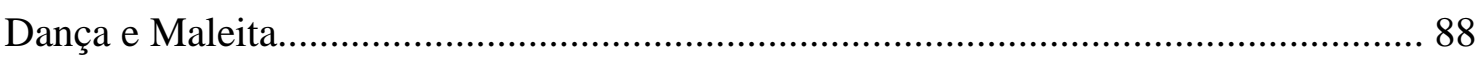

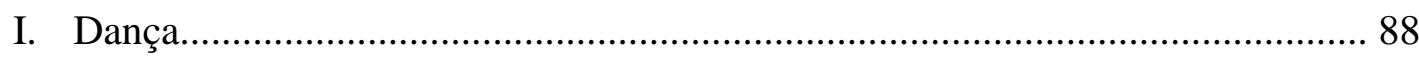

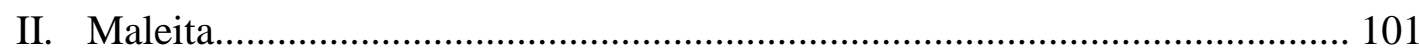

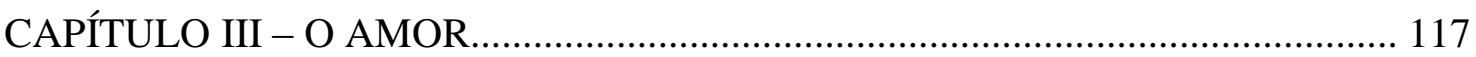

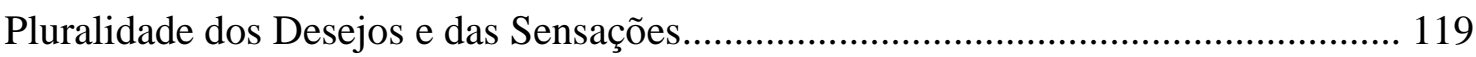

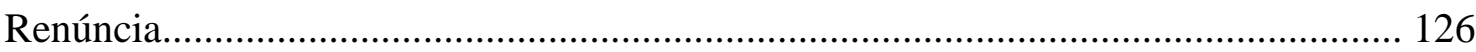

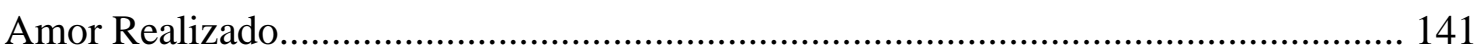

CAPÍTULO IV - SENTIMENTO RELIGIOSO DA VIDA................................... 162

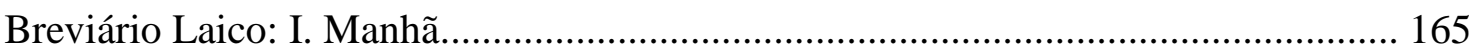

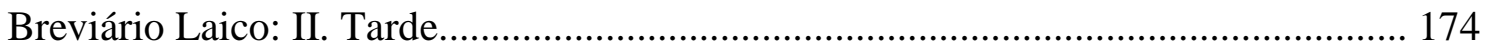

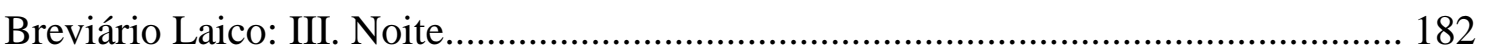




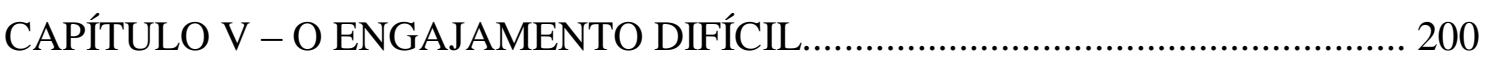

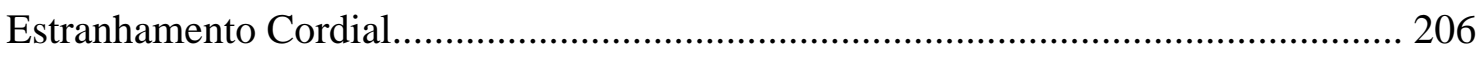

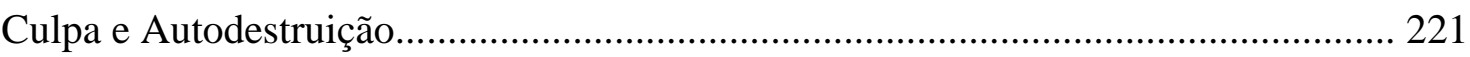

CONCLUSÃO - ACUMULAÇÃO POÉTICA, POSIÇÃO POLÍTICA

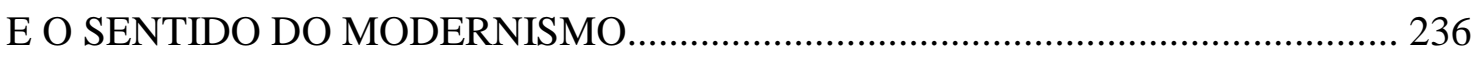

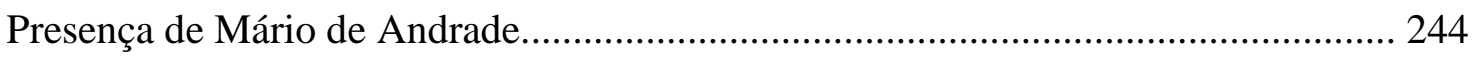

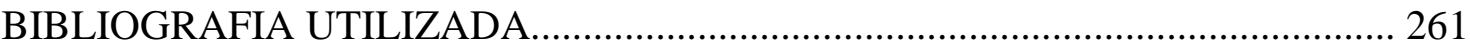


O meu amigo era tão de tal modo extraordinário, cabia numa só carta, esperava-me na esquina, e já um poste depois ia descendo o Amazonas, tinha coletes de música, entre cantares de amigo pairava na renda fina dos Sete Saltos, na serrania mineira, no mangue, no seringal, nos mais diversos brasis, e para além dos brasis, nas regiões inventadas, países a que aspiramos, fantásticos, mas certos, inelutáveis, terra de João invencível, a rosa do povo aberta...

Drummond 


\section{INTRODUÇÃO}

Toda a crítica devia se impor, de geração em geração, uma revisão de valores.

Mário de Andrade. O banquete

Quando iniciei a leitura sistemática da bibliografia sobre a poesia de Mário de Andrade vi, principalmente em suas abordagens mais genéricas e panorâmicas, que ela apresenta um tipo de senso comum: a atenção e o espaço dados aos diferentes momentos da sua obra poética eram inversamente proporcionais à melhoria progressiva de sua qualidade. O início década de 1920, com suas teorias poéticas e a Paulicéia desvairada (1922), toma a linha de frente, seguida de referência à pesquisa folclórica ao fim da década. Depois, um pouco en passant, e basicamente sem hierarquia, aparecem o poeta maduro de 1930, a dilaceração que o poeta sofre nessa década e seu direcionamento ao engajamento, bem como o momento de reavaliação, autocrítica e desolação da década de 1940. Assim, segundo esse consenso, o centro de força da obra de Mário de Andrade estaria na década de 1920, fundado principalmente em duas obras literárias: a já citada Paulicéia desvairada e Macunaíma (1928). Como poeta, a imagem de Mário ficaria indissoluvelmente presa à de iniciador do Movimento Modernista, um poeta cuja importância seria histórica e documental e que, no melhor dos casos, seria o precursor e o incentivador de uma poesia melhor que viria depois, feita por outros poetas. A bibliografia específica sobre a poesia de Mário de Andrade, porém, sem ignorar a importância desse primeiro momento de sua obra, não confirma a estreiteza desse senso comum. Ela se atém, como será mostrado em momento posterior desta Introdução, a momentos diversos de sua obra poética e, explícita ou implicitamente, tratam Paulicéia desvairada como um momento inicial, seguido por outros que desenvolvem e enriquecem a sua produção poética, superando em diversos sentidos o seu primeiro livro modernista. Contudo, se a bibliografia específica sobre a poesia de Mário não confirma o consenso sobre o autor, ela tampouco estabeleceu uma plataforma de leitura consistente que retificasse a visão generalizada e pusesse a leitura do conjunto da obra poética de Mário de Andrade em outras bases. Essa configuração dos (des)caminhos de leitura da poesia de Mário é ainda mais inquietante se considerarmos o fato de o próprio poeta, nos anos finais de sua vida, mais especificamente entre $1941 \mathrm{e}$ 
1945, ter procedido a algumas revisões de sua obra como um todo, e de sua obra poética em particular, e apontado, a partir da perspectiva final de sua obra, um modo de ler aquilo que veio antes. Ensaios como "A Elegia de Abril" (1941) e "O Movimento Modernista" (1942), o livro inacabado de diálogos artístico-filosóficos O banquete (1943-1945) e o poema “A Meditação sobre o Tietê" (1944-1945) oferecem uma revisão radical da atuação estética e política de Mário e do sentido de sua obra como um todo. Em relação à sua obra poética, "A Meditação sobre o Tietê” faz uma revisão intrapoética do seu conjunto. Levando em conta, então, o modo como o próprio autor preparou a leitura de sua obra, este trabalho propõe um estudo sobre a relação entre subjetividade lírica e nação em sua poesia. Na elaboração de uma perspectiva de estudo, depreende-se essa relação de seu último poema, “A Meditação sobre o Tietê”. A relação é em seguida desenvolvida no estudo de temas centrais em sua poesia - a configuração de uma subjetividade lírica, o amor, a religião, o posicionamento político - a partir de cortes transversais em sua obra poética. Essa perspectiva se propõe a tomar a obra em conjunto e a avaliá-la a partir de seu último momento. Não se trata de uma análise do poema “A Meditação sobre o Tietê" como um todo, ${ }^{1}$ mas de um sentido de análise crítica que começa pelo fim e pela reavaliação de conjunto presente na própria obra mariodeandradiana. A crítica neste trabalho busca, assim, sintonizar a seu modo a organização da perspectiva crítica, que tem sua própria forma e suas próprias demandas, com a organização que Mário de Andrade faz de sua obra poética a partir de dentro. Trata-se de organizar uma ordem de problemas e sua crítica a partir do conjunto da obra poética, com vistas a estruturas profundas, ${ }^{2}$ mas não se trata, de modo algum, de tentar exaurir as possibilidades de leitura e interpretação de sua poesia lírica. A aceitação da obra poética de Mário como um "bloco" é percebida como conveniente e aconselhada já em seus primórdios por seu interlocutor mais constante, Manuel Bandeira, em carta de 13 de setembro 1925: “A sua obra vai ser como as de Fagundes Varela e Castro Alves uma coisa grandalhona de que a gente não pode gostar em bloco, mas tem que aceitar

\footnotetext{
${ }^{1}$ Para uma recente análise do poema todo, ver MAJOR NETO, José Emílio. A Lira Paulistana de Mário de Andrade: a insuficiência fatal do outro. 2007. Tese (Doutorado em Teoria Literária e Literatura Comparada) - Faculdade de Filosofia, Letras e Ciências Humanas da Universidade de São Paulo, São Paulo, 2007.

${ }^{2} \mathrm{O}$ estudo das estruturas profundas da literatura brasileira se baseia fundamentalmente no trabalho de José Antônio Pasta Jr., cuja compreensão de conjunto da literatura, da história e da sociedade brasileira é exposta extensamente em aulas, palestras e conferências, e hipercondensadamente em textos críticos de circulação restrita, frequentemente escritos em francês e publicados na França, citados ao longo do trabalho e nas referências. Toda a interpretação desse trabalho, no entanto, exposto nesta tese, é de minha inteira responsabilidade.
} 
em bloco". 3 Faz-se necessário, então, como momento de análise, acionar uma suspension of disbelief e acompanhar o modo como o poeta encara sua obra.

Mário de Andrade sempre buscou dar à sua própria obra, inclusive e especialmente à obra poética, uma organização coerente. ${ }^{4}$ Desde o momento em que toma a frente da poesia modernista, em 1922, com Paulicéia desvairada, a poesia de Mário incansavelmente abre caminho a partir de si própria, no plano temático e no plano formal, vislumbrando caminhos e consolidando conquistas. Essa coerência de conjunto não é exterior aos poemas que a encampam, mas se configura em elemento formal em três níveis: um momento discursivo presente no corpo do texto poético, principalmente em poemas longos como "O Poeta Come Amendoim", "Noturno de Belo Horizonte" e "A Meditação sobre o Tietê", em que a sensibilidade poética faz uma curva retórica ascendente e se torna uma declaração de intenções; um ímpeto desbravador, que faz do poema um laboratório de pesquisas em termos de linguagem falada, folclore, inconstâncias psíquicas e afetivas, e máscaras sociais, ímpeto este que encontra solo fértil na precariedade das articulações da vida mental brasileira; e, por fim, o seu fundamento ordenador vai conferir a essa obra um sentido construtivo, a busca de afirmação e formação de uma cultura brasileira, com a intenção de lhe dar uma positividade profunda, pois visava a elementos que livrassem o brasileiro da dependência do padrão europeu, unissem os homens brasileiros em torno de valores comuns, e, em última instância, garantissem uma exemplaridade cívica. Quanto a este último item, cumpre notar e demonstrar que a obra poética de Mário está muito distante de uma posição escolar, de um oficialismo pedagógico e patriótico que pusesse a demanda de liberdade e autonomia da poesia moderna em função de algo que lhe fosse estranho e, sobretudo, redutor. Como elemento de universalidade - Mário nunca cansou de afirmar -, o Brasil dava fundamento a um modo de ser, de sentir e agir que franqueava a modernidade que nossa poesia podia ter.

Especificamente na obra de Mário de Andrade, a autonomia e liberdade da poesia moderna revertiam em uma função social por dois caminhos: pelo "realismo psicológico", que pela associação livre de imagens e pela exposição do inconsciente

\footnotetext{
${ }^{3}$ MORAES, Marco Antônio (Org.). Correspondência Mário de Andrade \& Manuel Bandeira. São Paulo: Edusp/IEB, 2001. p. 237.

${ }^{4}$ A própria obra de Mário de Andrade como um todo oferece material para entendimento, comentário e interpretação de sua poesia. Suas entrevistas, correspondências, diários de viagem, crônicas, obras de reflexão estética e social, historiografia e crítica literária, musical e de artes plásticas, estudos folclóricos, peças $(O$ café), contos e romances fornecem material abundante para entender a sua coerência, material de que procuro dispor sempre que elucide a pesquisa.
} 
elaboraria uma verdade psicológica para além da impostura psicológica e cultural determinada pelo padrão europeu e de qualquer outra norma, "desrecalcando" o brasileiro real; e pela elaboração de símbolos culturais comuns (que faz em Macunaíma uma síntese "épica”), facilitada pela abertura da poesia moderna para o cotidiano, para os desajustes e contrastes da vida moderna, em que o poeta podia desenterrar e articular sedimentações históricas, seja da língua, de objetos, símbolos, gestos, desalienando o brasileiro de sua própria realidade e, nesse sentido, conferindo uma função social à poesia moderna justamente pela via de sua autonomia.

A subjetividade lírica de Mário de Andrade busca constantemente tomar forma e expressar-se com traços da nacionalidade. Em contrapartida, a imagem do Brasil em sua poesia está temperada pelas idiossincrasias e disposições pessoais do poeta. Os modos pelos quais $e u$ e Brasil se entrelaçam podem, então, ser lidos de diversas maneiras, dada a complexidade e variedade de suas relações. No presente estudo, a perspectiva pretende focar esses momentos de entrelaçamento, em que a unidade de subjetividade lírica e de características da nacionalidade é apreendida em sua identidade e sua diferença. $\mathrm{O}$ procedimento é dialético e procura ler no entrelaçamento as passagens entre $e u$ e nação, diferenciando seus momentos. Em primeiro lugar, entretanto, a dialética se volta para as próprias categorias com que trabalha e as concebe como movimento. Subjetividade lírica e Brasil não são categorias estáticas, mas estão submetidas à sua própria lei de movimento. O $e u$ da poesia é fundamentalmente dinâmico e se define pelo contato com seu outro, a matéria histórica com que a categoria literária se relaciona, no caso, os modos de individuação e diferenciação do sujeito em um processo histórico e social específico. Igualmente, o Brasil é percebido como um nome para o qual converge uma via específica e ultracontraditória da história mundial moderna, via composta essencialmente pela transformação e manutenção de aspectos sociais aberrantes do ponto de vista da narrativa ortodoxa da história moderna. A principal aberração, linha mestra que orienta a leitura das demais, é a convivência entre aspectos avançados e normativos que orientam as transformações sociais e o funcionamento da cultura dos países mais avançados, por um lado, e, por outro, aspectos que não pertenceriam mais à história moderna, pois seria próprio dela dissolver esses estados mais antigos: a escravidão e a prática social sistemática do favor, ao longo do século XIX, e a iniquidade projetada por elas sobre o século XX, em que há Direitos do Homem sem igualdade perante a lei, industrialização sem cidadania e inclusão social em um Estado 
moderno definido por práticas patriarcais e paternalistas. Como esses são os temas fundamentais da sociologia brasileira, ${ }^{5}$ não me estendo na caracterização dos traços de exceção que compõem o processo histórico da sociedade brasileira, os quais não deixam de ser um momento específico e revelador da natureza conjunta e desigual da história mundial moderna. $\mathrm{O}$ que há para destacar nessas linhas muito gerais que descrevem o movimento (ou a falta de movimento) da história brasileira para as finalidades deste estudo é a profunda heterogeneidade de aspectos que a definem e que estão disponíveis como matéria histórica e material artístico $^{6}$ para o poeta que queira, como quis Mário de Andrade, dar-lhe coerência e sentido construtivo.

No plano social do indivíduo, Mário fez considerações importantes sobre a diferença da subjetividade europeia e a sul-americana. Observando em sua viagem amazônica a diferença de comportamento entre os tripulantes europeus de seu navio e os brasileiros, Mário escreve: "Dizer então que me lembrei de uma amiga judia francesa comunista que me crible de lettres sobre a infelicidade social dela, dos operários etc. Me lembrei de escrever pra ela uma carta amazônica, contanto esta 'dor' sulamericana do indivíduo. Sim eles tem a dor teórica, social, mas ninguém não imagina o que é esta dor miúda, de incapacidade realizadora do ser moral, que me deslumbre e afete". 7 E prossegue o nosso autor escrevendo a carta imaginada à sua amiga, em que há essa interessante passagem sobre "nos gentilles âmes imparfaites": "N'avez vous pas senti nos peurs américaines, et nos impossibles? O que é Hitler, Deladier, a impotência, a clarividência criminosa. Os vossos operários europeus? Eles não sofrem não, eles teorizam sobre o sofrimento. A dor, a imensa dor do irreconciliável humano, sempre imaginei que ela viajara na primeira vela de Colombo e vive aqui. Essa dor não é de ser operário, que não é de intelectual, que independe de classes e de políticas, de

\footnotetext{
${ }^{5}$ Para uma orientação sobre os temas centrais do pensamento sobre o Brasil e da sociologia brasileira, ver RICUPERO, Bernardo. Sete lições sobre as interpretações do Brasil. São Paulo: Alameda, 2008 e SCHWARZ, Roberto. Um seminário de Marx. Sequências brasileiras. São Paulo: Companhia das Letras, 1999.

${ }^{6}$ Entendo aqui "matéria histórica" como a matéria ainda não pré-figurada artisticamente com que o poeta trava contato e busca formalizar, consciente ou inconscientemente, e "material histórico" como o conjunto dos elementos de composição disponíveis para o artista. O conceito de "material" na obra Adorno pode ser lido com proveito em ALMEIDA, Jorge de. Crítica dialética em Theodor Adorno. Música e verdade nos anos vinte (São Paulo: Ateliê, 2007), principalmente o capítulo de conclusão A Dialética do "Material". Para um exemplo tirado da poesia de Mário, o "seringueiro" de "Dois Poemas Acreanos" é matéria histórica, a forma do "Coco", composição musical nordestina utilizada pelo poeta, é "material".

${ }^{7}$ ANDRADE, Mário de. O turista aprendiz. Belo Horizonte: Itatiaia, 2002. p. 149. Os trechos em francês fazem parte do texto original.
} 
aventureiros Hitlers e de covardes Chamberlains, a dor dos irreconciliáveis vive aqui”. 8 Essa heterogeneidade dolorosa que Mário nota no indivíduo tem uma analogia necessária na configuração do país. Como exemplo, pode-se ler a observação do historiador Pedro Calmon, colhida no livro de Roger Bastide, Brasil: terra de contrastes, sobre a justaposição de tempos históricos em nossa geografia:

Partindo do litoral para se embrenhar no interior, o viajante assiste ao milagre da máquina de remontar o tempo. Junto do Atlântico, as grandes cidades tentaculares com seus arranha-céus ébrios de orgulho, que esmagam sob suas massas imponentes as flechas minúsculas das igrejas, com fábricas barulhentas, com cinemas luxuosos e, à noite, com os milhares de anúncios luminosos, verdes, vermelhos, brancos, suspensos como ramos de flores noturnas ao longo das fachadas, já nos fazem viver no Brasil futuro. Mais adiante, as pequenas cidades do interior, quietas, sossegadas, casas térreas enquadrando jardins onde namorados ainda passeiam romanticamente sob os olhos enternecidos dos pais, dão-nos a imagem do que deve ter sido o Brasil Imperial. Depois, chega-se aos povoados em que ainda perdura o estilo de vida colonial, com suas famílias patriarcais, separação dos sexos no interior dos lares, armazéns obscuros em que se vende de tudo, das trempes de cozinha até a farmácia homeopática, das peças de fazenda até a História de Carlos Magno e os 12 Pares de França. É assim que remontamos, através de todas estas épocas históricas milagrosamente conservadas, até chegar finalmente à civilização mais primitiva, ao neolítico dos indígenas do Mato Grosso e de Goiás. ${ }^{9}$

Esse o Brasil com que se deparou e trabalhou o nosso primeiro Modernismo. A superposição de tempos históricos também podia e pode, no entanto, ser notada em um mesmo ponto geográfico, funcionando o tempo histórico passado conjugado com o tempo histórico presente. Hoje, com a expansão da televisão e da tecnologia em geral, tudo mudou um pouco, mas não muito. Do ponto de vista da forma poética, que é o desta pesquisa, a vanguarda artística internacional do início do século XX criava uma

\footnotetext{
${ }^{8}$ ANDRADE, Mário de. O turista aprendiz, cit., 2002. p. 149. O texto dessa passagem data de 1927, antes de Hitler e o nazismo rebaixarem a "dor" da individualidade europeia a níveis brasileiros. Sobre a relação entre a ação do nazismo na Europa e das metrópoles europeias em suas colônias, é importante relembrar essa passagem de Aimé Césaire: "O que o cristianíssimo burguês do século XX não perdoa a Hitler não é o crime em si, o crime contra o homem, não é a humilhação do homem em si, é o crime contra o homem branco [...] é ter aplicado à Europa procedimentos colonialistas que, até então, só se destinavam aos árabes, aos cules da Índia e aos negros da África" (apud FERRO, Marc. História das colonizações. São Paulo: Companhia das Letras, 1996. p. 14). Original em francês: "au très distingué, très humaniste, très chrétien bourgeois du XXe. siècle [...] ce qu'il ne pardonne pas a Hitler, ce n'est pas l'humiliation de l'homme en soi, c'est le crime contre l'homme Blanc, c'est l'humiliation de l'homme Blanc, et d'avoir appliqué à l'Europe des procédés colonialistes dont ne relevaient jusqu'ici que les Arabes d'Algérie, les coolies de l'Inde et les nègres d'Afrique" [grifo do original] (CÉSAIRE, Aimé. Discours sur le colonialisme. Paris: Présence Africaine, 2004. p. 13-14).

${ }^{9}$ BASTIDE, Roger. Brasil: terra de contrastes. São Paulo: Difel, 1973. p. 10.
} 
sincronia imprevista entre as novas estéticas primitivistas de Paris e o cotidiano de tempos históricos entrelaçados do Brasil. Como notou Antonio Candido: "no Brasil as culturas primitivas se misturam à vida cotidiana ou são reminiscências ainda vivas de um passado recente. As terríveis ousadias de um Picasso, um Brancusi, um Max Jacob, um Tristan Tzara, eram, no fundo, mais coerentes com a nossa herança cultural do que com a deles". 10 Análise que condiz com a consciência efetiva que tinham nossos modernistas sobre o tema, como diz Oswald de Andrade: "O primitivismo que na França aparecia como exotismo [...] era para nós, no Brasil, primitivismo mesmo". ${ }^{11} \mathrm{O}$ modo como as formas da vanguarda internacional se relacionavam com o ambiente artístico, histórico e social brasileiro pode ser documentado por meio de dois textos em que Mário de Andrade reflete muito conscientemente sobre essa questão. No primeiro, “Convalescença”, de 1923, Mário comenta a recepção da Semana de Arte Moderna, realizada no ano anterior, e, ao final do texto, lemos essa passagem:

Há de facto em nosso futurismo quebra da evolução brasileira. É que, coisa mil vezes dita, durante quase século, com lustros de atraso, fomos uma sombra de França. Sombra doirada. Sempre sombra. Nós, os modernistas, quebramos a natural evolução. Saltamos os lustros de atraso. Apagámos a sombra. Mas somos hoje a voz brasileira do coro "1923”, em que entram todas as nações. Poderia documentá-lo. E por isso a solução de continuidade na tradição artística brasileira. Nem o grande Cruz e Sousa e um ou outro decadente simbolista, bastam para justificar o nosso presente. Ha, confesso, uma quebra pela qual, aos vesgos, somos chocantes e aparentemente exagerados. Como do academismo e impressionismo anafados evolucionar para Anita Malfatti, num país onde não ecoaram as pesquizas de Seurat, van Gogh, Cezanne? Como de Bernardelli evolver para Brecheret, sem Metzner, Milles, Mestrovic? Hiato. E a grita aflita das araras. Será preciso noutros países buscar a nossa evolução. Mas nem por isso deixamos de ser a voz brasileira no movimento que hoje se desenha universal ${ }^{12}$ [grifo do original].

Em texto de 1924, analisando o romance Memórias sentimentais de João Miramar, Mário retorna à questão da relação entre Modernismo e realidade histórico-

${ }^{10}$ CANDIDO, Antonio. Literatura e cultura 1900-1945. Literatura e sociedade. Rio de Janeiro: Ouro sobre Azul, 2008. p. 128.

11 RAMOS, Péricles. O Modernismo na Poesia. Apud COUTINHO, Afrânio (Org.). A literatura no Brasil. São Paulo: Global, 2004. v. V - Era modernista, p. 50. O tema da operação realizada pelo Modernismo, de tornar positiva uma herança colonial que até então era sentida como negativa, foi recuperado recentemente em textos de Roberto Schwarz e Vinícius Dantas, que serão trazidos para a discussão na revisão da fortuna crítica.

12 ANDRADE, Mário de. Convalescença. Revista do Brasil, n. 92, p. 339, ago. 1923. Reproduzi a ortografia original do texto. 
social brasileira, desenvolvendo as questões colocadas pelo texto que acabamos de citar. A citação será longa, mas acredito que ela seja fundamental para entender o espírito analítico e consciente de Mário de Andrade que preside à sua atuação modernista:

É muito sabido já que um grupo de moços brasileiros pretendeu tirar o Brasil da pasmaceira artística em que vivia, colocando a consciência nacional no presente do universo. Grande espanto, indignação mesmo, provocados pela grita desses galos turbulentos e nem sempre razoáveis. Mas estes já sabiam que sempre se irrita quem acorda no meio do sono. O erro deles foi imaginar que os cocoricos adiantam a aparição da madrugada. Tinham de transportar a consciência nacional para o presente do universo. Muito bem. Mas onde estava a consciência nacional? Havia a fonte dos escritores... Mas essa tradição (!) não dizia nada. As poucas tentativas de um Basílio da Gama, dum Gonçalves Dias, dum Alencar era falhas, porque intelectuais em vez de sentidas, porque dogmáticas em vez de experimentais, idealistas em vez de críticas e práticas, divorciadas do seio popular, descaminhadas da tradição, ignorantes dos fatos e da realidade da terra. Apenas alguma coisa da ironia do caboclo, da sua melancolia, do sentimentalismo do brasileiro urbano, da petulância pernóstica do mulato e sua chalaça lusa se podia aprender na obra dum Gregório de Matos, dum Casimiro de Abreu, dum Álvares de Azevedo. Outros pouquíssimos. O resto eram pátrias-latejo-em-ti gritalhões, idealistas, inócuos. Nesse sentido os regionalistas tinham grande valor.

Verdade é que si todos esses homens de grande talento mas paupérrimos de inteligência crítica (esta observação não é minha) nada conseguiram, isto se deu também porque ainda não existia uma consciência nacional. Pode-se dizer que houve uma consciência paulista durante o bandeirismo. Ainda uma consciência baiana, ou quase, no segundo século. Consciência verdadeiramente brasileira ainda não se caracterizou nem mesmo nos trabalhos da independência, nem mesmo na guerra do Paraguai. O fato de em tais períodos existir um grupo de homens orgulhosos da sua nacionalidade e cuidadosos dos destinos do país não implica e infelizmente nem gera uma consciência nacional que tem de ser íntima, popular e unânime.

É o caso de me perguntarem si essa consciência nacional existe agora. Não existe. Eu já disse que imaginávamos com os cocoricos adiantar o momento da aurora.

Era preciso pois auscultar, descobrir, antes: ajudar o aparecimento da consciência nacional. As pesquisas se multiplicam nesse sentido entre os modernistas brasileiros. [...] A realidade brasileira, agora criticada e não apenas sentimental caracteriza já claramente o trabalho desse grupo, não escola, grupo que por vário caminho se dirige para o mesmo fim. ${ }^{13}$

\footnotetext{
${ }^{13}$ ANDRADE, Mário de. Osvaldo de Andrade. Revista do Brasil, ano IX, v. XXVII, p. 31-32, set./dez. 1924. Republicado em BATISTA, Marta Rossetti; LOPEZ, Telê Porto Ancona; LIMA, Yone Soares de. Brasil: $1^{\circ}$ tempo modernista - 1917/29. Documentação. São Paulo: IEB, 1972. p. 223-224. Segui a ortografia do texto republicado.
} 
Por essa longa citação se vê o quanto o nacionalismo modernista era oriundo das necessidades internas da vanguarda artística no Brasil e o quanto a relação da subjetividade lírica com a nação era um problema estrutural da poesia de Mário e do Modernismo brasileiro de um modo em geral. Assim, as diferentes configurações dessa subjetividade lírica e dessa simultaneidade de tempos históricos serão aqui estudadas no que tange especificamente à poesia de Mário de Andrade, mas que não perde o horizonte do sentido histórico que teve todo o Movimento Modernista na reavaliação da cultura e da vida social brasileiras. Esse então o Brasil historicamente específico, que entra em contato com um sujeito igualmente específico na obra poética de Mário de Andrade, e cujo resultado estético, compreendido em suas diferentes realizações, é o objetivo deste estudo.

\section{Fortuna Crítica}

Entendemos então o eu e o Brasil na obra poética de Mário de Andrade como categorias literárias que se dialetizam com momentos específicos de um processo histórico em curso. O primeiro capítulo desse entrelaçamento entre $e u$ e Brasil em nada deixa prever o desenvolvimento posterior do poeta. Nem mesmo de "Brasil" se trata, mas da cidade de São Paulo. Os primeiros escritos sobre o poeta, a crítica especificamente modernista, nota no poeta de Paulicéia desvairada a captação formal da grande cidade, "'girl' babilônica que é esta cidade de mil portas". ${ }^{14}$ A essa atualização estética na esteira do crescimento paulista correspondia um vitalismo do sujeito lírico, que vivia intensamente seus poemas. ${ }^{15}$ Já em 1922, observando a unidade do livro e a segurança da sua teoria poética, Manuel Bandeira, ainda hoje um dos melhores leitores da poesia de Mário, declarava: “A arte de Mário de Andrade é de uma unidade inatacável". ${ }^{16}$ Não estou aqui debatendo os diversos problemas e complexidades da fatura e da teoria poética que informam esse primeiro livro, mas

\footnotetext{
${ }^{14}$ ANDRADE, Oswald de. O meu poeta futurista. Jornal do Comércio. São Paulo, 27/05/1921. Apud BRITO, Mario da Silva. História do modernismo brasileiro. Rio de Janeiro: Civilização Brasileira, 1981. v. I - Antecedentes da Semana de Arte Moderna, p. 228.

${ }^{15}$ BANDEIRA, Manuel. Mário de Andrade [1922]. Crônicas inéditas. São Paulo: Cosac e Naify, 2008. v. 1, p. 25. Sobre o sujeito lírico em Paulicéia desvairada, ver LAFETÁ, João Luiz. A representação do sujeito lírico na Paulicéia desvairada. A dimensão da noite. São Paulo: Duas Cidades/Editora 34, 2004.

${ }^{16}$ BANDEIRA, Manuel. Mário de Andrade [1922]. Crônicas inéditas, cit., p. 26. Sobre essa primeira teoria poética de Mário, muito comentada, leem-se com proveito os textos de Maria Helena Grembecki, Roberto Schwarz, que comentarei mais adiante, e GÓES, Fernando. História da Paulicéia desvairada. Revista do Arquivo Municipal de São Paulo. Homenagem a Mário de Andrade. CVI, jan. 1946.
} 
apenas acompanhando de que modo $e u$ e Brasil vão se encontrando ao longo de sua obra. A nova identificação do sujeito lírico, não mais com a cidade de São Paulo, mas com o conjunto do país foi alcançada, seguindo ainda leitura de Manuel Bandeira, por meio da linguagem, no livro Losango cáqui (composto em 1922 e publicado em 1926): "No que diz respeito à linguagem, Losango cáqui é o primeiro livro escrito em nossa língua. Adotando sintaxes e expressões correntes na conversação da gente educada, idiotismos brasileiros, psicologia brasileira, Mário de Andrade conseguiu escrever brasileiro sem ser caipira nem rude". ${ }^{17} \mathrm{O}$ Brasil se dilui tanto em expressões e comparece na linguagem, quanto no modo de ser psicológico do eu lírico. A liberdade do fluxo lírico inconsciente e a disposição de trabalho construtivo da linguagem - os itens de sua primeira teoria poética - ultrapassam o que pareciam ser polos estáticos e estanques de sua teoria, fluxo de lirismo e trabalho artístico, por meio da prática poética e da disponibilidade expressiva do sujeito lírico.

Até então a poética de Mário ia pelo “psicologismo", expressão pura do inconsciente trabalhada posteriormente pela consciência da coerência formal e de linguagem. O primitivismo e o interesse pelo Brasil folclórico lhe chegam por meio do diálogo com Oswald de Andrade e Tarsila do Amaral a propósito da relação entre cubismo parisiense e realidade brasileira. Desse diálogo resulta um esforço de reflexão conjunta cujos resultados foram o Manifesto da Poesia Pau-Brasil (1923) e o livro PauBrasil (1925), de Oswald, o poema "Noturno de Belo Horizonte" (1924), de Mário, e o quadro “A Negra” (1923) de Tarsila. ${ }^{18}$ A inclinação de brasilidade já presente na linguagem de Losango cáqui recebe assim novo fôlego, gerando em Mário de Andrade a intenção de imergir completamente a sua obra nas fontes brasileiras. Desse momento de identificação plena do eu lírico com o Brasil resulta em poesia no Clã do jabuti (1927), no plano da reflexão intelectual, no Ensaio sobre a música brasileira (1928) e, no romance, em Macunaíma (1928), frutos de um mesmo esforço de pesquisa e formalização do Brasil. O livro de poemas em questão (por motivos óbvios não tratarei da recepção de Macunaíma) é nitidamente construtivo, o que é percebido por críticos anteriores ao Modernismo. João Ribeiro fala de "um tratado ou uma corografia poética

\footnotetext{
17 BANDEIRA, Manuel. Reservista poeta. Mário de Andrade: Losango Cáqui [1926]. Andorinha, andorinha. Rio de Janeiro: José Olympio, 1983. p. 181. Sobre as datas de composição e publicação, ver a "Advertência" de Mário no próprio livro.

${ }^{18}$ Sobre o diálogo dos três artistas, ver DANTAS, Vinícius. Entre "A Negra” e a Mata Virgem. Novos estudos. São Paulo, n. 45, jul. 1996. Tratei no Capítulo IV desta tese do poema "Noturno de Belo Horizonte" sob a ótica desse diálogo.
} 
do Brasil"; ${ }^{19}$ Nestor Vitor, no que seja talvez a intuição mais brilhante sobre o significado do livro, comenta sobre seu trabalho de linguagem: "Parece um "tour de force' diametralmente antagônico ao que representam as Sextilhas de Frei Antão". ${ }^{20}$ Com esse livro, Mário apresenta o aproveitamento poético de um folclorismo sério, sensível à particularidade regional e à concretude do processo histórico em diversas partes do território brasileiro. Talvez, de nossos modernistas, só a ele caiba, adaptado para a poesia, o comentário de Adorno à música de Bartók, outro folclorista adulto, de que: “o que é próprio da canção popular nunca se coloca como elemento estilístico discretamente ressaltado, antes é em toda parte apreendido pelo processo compositivo subjetivo, sendo perpassado por ele como apenas na realidade o Eu e a objetividade se perpassam". ${ }^{21}$ Aqui está uma possível perspectiva crítica da identificação entre eu e Brasil na obra poética de Mário.

A recepção de Remate de Males (1930) é feita basicamente pelos mesmos críticos que vinham acompanhando o trabalho do poeta. A renovação que se opera na poesia daquele $a^{22}$ não teve desdobramento na atividade crítica. A única recepção que acompanha essa radicalização é à direita, no texto do católico ortodoxo Tristão de Ataíde, que condena a baixa espiritualidade do poeta nesse livro, e seu excesso de cerebralismo. Mário agora seria complacente com o mundo exterior e os "amores fáceis". Conformista (!), enfim. ${ }^{23}$ Enquanto Tristão de Ataíde ia perdendo o fio da meada, Manuel Bandeira compreendia o grande avanço poético do livro: os momentos de repouso contemplativo de "Poemas da Negra" e "Poemas da Amiga" davam, em termos de linguagem e observação, uma familiaridade profunda com a vida brasileira. $\mathrm{O}$ que é exótico para os próprios brasileiros, exterioridade pura, recebe de Mário uma intimidade poética, tornando-os objeto de poesia sem nacionalismo complacente. Contudo, esse ponto de consolidação de conquistas poéticas marca uma virada

\footnotetext{
${ }^{19}$ RIBEIRO, João. O Clã do Jaboti [1928]. Os modernos. Rio de Janeiro: Academia Brasileira de Letras, 1952. p. 85 .

${ }^{20}$ VITOR, Nestor. Mário de Andrade [1928]. Os de hoje. São Paulo, Cultura Moderna, 1938. p. 159. Sobre a linguagem "brasileira" de Mário, ver PINTO, Edith Pimentel. A gramatiquinha da fala brasileira. São Paulo: Duas Cidades, 1990.

${ }^{21}$ ADORNO, Theodor W. Über einige Werke von Bela Bartók (1925). Gesammelte Schriften. Frankfurt am Main: Suhrkamp, 1984. v. 18. Apud ALMEIDA, Jorge de. Crítica dialética em Theodor Adorno. Música e verdade nos anos vinte, cit., p. 234. Sobre o Mário folclorista, ver LOPEZ, Telê. Mário de Andrade: ramais e caminho. São Paulo: Duas Cidades, 1972 e FERNANDES, Florestan. Mário folclorista. Revista do Arquivo Municipal de São Paulo, cit.

${ }^{22}$ ANDRADE, Mário de. Poesia em 1930 [1931]. Aspectos da literatura brasileira. Belo Horizonte: Itatiaia, 2002.

${ }^{23}$ ATHAYDE, Tristão de. Mais vozes de perto. Estudos. Rio de Janeiro: Civilização Brasileira, 1933. $5^{\text {a }}$ Série, p. 133.
} 
fundamental na relação entre $e u$ e Brasil para Mário: a perda do entusiasmo renovador e a reflexão do $e u$ sobre a estruturação real (e não idealizada, como no entusiasmo do primeiro modernismo) do país com o qual se identifica. Ainda aqui é Bandeira, seu primeiro grande leitor, que avança a interpretação: “Os 'Poemas da negra' e os 'da amiga' parecem vir de um isolamento enorme, mas de um isolamento em que não se pode falar nem de tristeza nem de alegria. Será de indiferença?". ${ }^{24}$ Bandeira conclui que o poeta soube conformar o rumo da própria vida com serenidade e sabedoria. Essa espécie de indiferença elevada, em contraste com o que foi o projeto poético e intelectual anterior, titânico em seu ânimo transformador, dá um sentido histórico de mudança de perspectivas na relação entre $e u$ e nação. Não mais uma identificação plena, mas um relativo estranhamento. Um cansaço desilusório do que foi o entusiasmo, que rendia grandes frutos ao artista e intelectual, mas pouco progredia na consolidação de uma nação consciente de si. Eu e Brasil começavam a tomar rumos diferentes, e, nesse momento preciso, com ar de elegia, o poeta medita sobre seu trajeto. O próprio título do livro indica esse novo estranhamento, pois Remate de Males é uma cidadezinha amazônica fronteiriça com o Peru, que, visitada por Mário em sua viagem pelo Norte em 1927, se caracterizava por não ter nada. Quando o viajante pedia algo aos habitantes da cidade, a resposta era sempre negativa e pejorativa, aqui vai um sumário: "Não tem coisa nenhuma [...] ninguém faz nada nesta terra desgraçada. [...] difícil de sustentar nesta terra desgraçada. [...] não plantam! - Ah... é uma terra desgraçada. [...] aquela gente, sem uma exceção, comida pela maleita". ${ }^{25}$ A conclusão do poeta antecipa algo do que vai ser essa necessidade de repouso, e adianta um dos seus grandes símbolos poéticos: "Então desejei ser maleiteiro, assim, nada mais me interessar neste mundo em que tudo me interessa por demais...". ${ }^{26}$ A mudança é decisiva, o Brasil deixa de ser "na Terra o grande milagre do amor" ("Noturno de Belo Horizonte") para ser Remate de Males.

Quando projetou a publicação desse livro de 1930, Mário imaginava ter encerrado sua obra de poeta. Assim ele se expressa em carta a Bandeira de 15 de julho de 1930:

\footnotetext{
24 BANDEIRA, Manuel. Mário de Andrade [1931]. Crônicas da província do Brasil. São Paulo: Cosacnaify, 2007.

${ }^{25}$ ANDRADE, Mário de. O turista aprendiz. Belo Horizonte: Itatiaia, 2002. p. 98.

${ }^{26}$ ANDRADE, Mário de. O turista aprendiz, cit., p. 98.
} 
Agora estou organizando o Remate de Males pra imprimir. Este livro me assusta, palavra. Tem de tudo e é a maior mixórdia de técnicas, tendências e concepções díspares. Mas gosto disso bem. "Eu sou trezentos, sou trezentos e cinqüenta" como digo num dos poemas. Terá "Danças”, “Tempo de Maria” (alguns só), "Poemas da negra”, "Poemas da amiga" e uma série de poesias soltas que ainda não denominei e estou achando dificuldade pra batizar. Há no livro alexandrinos parnasianos, decassílabos românticos, simultaneidade, surrealismo quase, coisas inteligibilíssimas e poemas absolutamente incompreensíveis. Talvez uma abundância excessiva. Mas é que pretendo me livrar da poesia pra todo o sempre ${ }^{27}$ [grifo meu].

Apesar da intenção de abandonar a poesia, Mário não foi capaz de evitar o que ele mesmo chamou de "estado poético", o que fez com que sua produção poética continuasse e expressasse, ao longo da década de $1930,{ }^{28}$ um grande dilaceramento interior. Contudo, o poeta passa toda a década sem publicar poemas. Esses dez anos de silêncio poético são encerrados com livro Poesias, de 1941, que reunia sua obra anterior e acrescentava os livros A costela do Grã Cão e Livro azul. São poemas escritos ao longo da década de 1920 e 1930. A relação entre sujeito lírico e Brasil, agora tencionada pela consciência de uma história cujo curso é destrutivo, se fortalece, em lugar de diminuir. $\mathrm{O}$ caso oferece uma imagem de seriedade intelectual em que é preciso se deter. Pensemos nos modernistas de primeira ou segunda hora que, tomando consciência do tamanho do problema que era o Brasil, abandonaram a relação entre eu lírico e nação e foram voar em outras asas. Da postura "pau-brasil" para a sagração da santíssima trindade foi um passo, assim como o caminho pareceu fácil do totemismo da Anta ao Integralismo totalitário. Mário, sem abandonar sua posição de proa, foi aprofundando as relações entre a constituição do $e u$ e o processo histórico-social. A questão é menos de fidelidade, que também havia, do que da estatura realmente elevada do intelectual sério que, sem se comprometer com (ou se alienar de) um curso histórico que repudia, não abandona sua capacidade de reflexão histórica e crítica, e formalização poética de sua hora humana. Estamos navegando nas águas de um Goethe, se é que é

\footnotetext{
${ }^{27}$ MORAES, Marco Antônio (Org.). Correspondência Mário de Andrade \& Manuel Bandeira, cit., p. 452.

${ }^{28}$ Como diz, em outro contexto, em carta a Drummond de 23 de julho de 1944: "me voltou um estado poético, essa coisa enfim de quando a gente fica em poesia por dentro, de dentro pra fora e faz, vira poesia objetivada no papel, pouco importa se ruim ou boa" [grifo do original] (SANTIAGO, Silviano (Org.). Carlos \& Mário. Correspondência de Carlos Drummond de Andrade e Mário de Andrade. Rio de Janeiro: Bem-Te-Vi, 2002. p. 513).
} 
possível pensar em algo goethiano no Brasil. ${ }^{29}$ Quando Poesias é publicado, a crítica literária brasileira acabara de alcançar sua maturidade. Encampada pelas conquistas de uma literatura brasileira moderna, em cujo contato os críticos podiam se desenvolver, e pela aquisição de novas metodologias universitárias europeias e norte-americanas, floresce a "crítica de rodapé", que antecede e lança as bases da futura crítica universitária. Mário, na década de 1940, cita três críticos profissionais: Álvaro Lins, Antonio Candido e Sérgio Milliet. ${ }^{30}$ Os dois primeiros publicaram textos sobre o livro em questão. Sérgio Milliet, por sua vez, publica um texto após a morte de Mário, sobre o "poeta Mário de Andrade". ${ }^{1}$ Esse ensaio, porém, não faz jus ao termo "crítico profissional" de Mário, pois está ainda preso à crítica impressionista e sofre das irregularidades de gosto e humor do autor, não mediadas por categorias críticas. Os poucos bons comentários do texto, como a defesa da poesia social de Mário, se devem antes ao talento do crítico do que ao avanço dos procedimentos técnicos de leitura. Não assim as leituras de Álvaro Lins e Antonio Candido, que ainda enfileiram com a melhor crítica sobre o poeta. A atenção de Álvaro Lins já lança com segurança as grandes linhas para a leitura da poesia de Mário: "Duas ordens de preocupações, duas espécies de motivo revelam-se dominantes no Sr. Mário de Andrade: o sentimento de sua terra e o seu sentimento íntimo de homem". ${ }^{32}$ Os acertos e exageros da sua linguagem poética, submetidos ao critério da concisão moderna, as disposições sociais de sua poesia e o movimento do $e u$ são lidos de forma penetrante e compreensiva, o que mantém sua atualidade. O texto de Antonio Candido, que já se inicia com uma hermenêutica da relação entre crítico e poesia, faz uma verdadeira anatomia, equilibrada pela sensibilidade do crítico, da poesia de Mário: os aspectos do poeta, que é um “descobridor construtivo", são: poeta folclórico, poeta do cotidiano, poeta de si mesmo

\footnotetext{
${ }^{29}$ Mário usa o termo "olimpismo" em carta a Manuel Bandeira de 10 de agosto de 1934: "Eu desejei mesmo um certo olimpismo, uma certa sobreelevação acima dos tumultos terrenos, desprezando o terra-aterra. Deu no tom azul dos 'Poemas da negra' e da 'Amiga', no tom mais doirado do 'Girassol' e quase branco do 'Rito do irmão pequeno"' (MORAES, Marcos Antônio (Org.). Correspondência de Mário de Andrade \& Manuel Bandeira, cit., p. 582-583). Sobre sua concepção de "torre de marfim", ideal de independência e compromisso elevado do intelectual, ver carta a Drummond de 11 de fevereiro de 1945 em SANTIAGO, Silviano (Org.). Carlos \& Mário. Correspondência de Carlos Drummond de Andrade e Mário de Andrade, cit., p. 539.

${ }^{30}$ ANDRADE, Mário de. Cartas de Mário de Andrade a Álvaro Lins. Rio de Janeiro: José Olympio, 1983. p. 105. A evolução mais orgânica desse movimento foi a da crítica de rodapé de Antonio Candido Mello e Souza e o curso de Letras da Universidade de São Paulo. No caso do Rio de Janeiro, o processo é menos linear, pois quem funda os estudos universitários é Afrânio Coutinho.

${ }^{31}$ MILLIET, Sérgio. O poeta Mário de Andrade. Revista do Arquivo Municipal de São Paulo, cit.

${ }^{32}$ LINS, Álvaro. Jornal de crítica. Rio de Janeiro: José Olympio, 1943. $2^{\mathrm{a}}$ Série. Republicado em LINS, Álvaro. Os mortos de sobrecasaca. Rio de Janeiro: Civilização Brasileira, 1963. p. 41.
} 
e o criador de poética; suas maneiras são três: maneira de guerra de Paulicéia desvairada, fase de encantamento rítmico e abertura às sugestões populares, e a maneira despojada, que abaixa o tom e busca o essencial; os principais temas são quatro: o tema do Brasil, o tema do conhecimento amoroso (e do amor falhado), o tema do autoconhecimento e da conduta em face do mundo. ${ }^{33}$ A passagem da crítica impressionista para a crítica profissional, que visa ao conhecimento produtivo e acumulativo, o qual busca ser compartilhado e cujo sentido é democrático, não podia ser mais clara. O estudo da poesia de Mário de Andrade se enriquece de matizes, perspectivas e conclusões, dando nova dimensão à relação entre subjetividade lírica e nação, agora desenvolvida em um percurso próprio, aberto à análise interpretativa.

A partir de então, torna-se secundária a crítica extra muros, e o fio tem de ser retomado pelos estudos universitários. Antes, entretanto, de voltarmos à fortuna crítica, alguns aspectos externos completam o quadro que tento montar. $\mathrm{O}$ último livro de poemas publicado em vida por Mário foi Poesias em 1941. Conta Antonio Candido ${ }^{34}$ que "dois ou três dias" após a morte de Mário de Andrade, recebeu um envelope grande que Mário deixara sobre sua própria mesa endereçado a ele. Eram os poemas de Lira paulistana, O carro da miséria e "A Meditação sobre o Tietê", que teve a edição preparada pelo próprio crítico, em 1946. Eis o primeiro capítulo da história de conservação e zelo da obra de Mário de Andrade. ${ }^{35}$ A primeira abordagem de extração

\footnotetext{
${ }^{33}$ CANDIDO, Antonio. Mário de Andrade. Poesias. Revista do Instituto de Estudos Brasileiros, n. 36. São Paulo: IEB, 1994. p. 136-137. (Publicado originalmente na revista Clima, n. 8. São Paulo, jan. 1942.) ${ }^{34}$ SOUZA, Gilda de Mello e; SOUZA, Antonio Candido de Mello e. A lembrança que guardo de Mário. Revista do Instituto de Estudos Brasileiros, n. 36, cit., p. 15.

${ }^{35}$ Inicialmente, Antonio Candido orienta, entre 1963 e 1968, os primeiros trabalhos sobre a biblioteca de Mário de Andrade com base em seu acervo que ainda pertencia à sua casa na Rua Lopes Chaves, 546. São três trabalhos de mestrado: Mário de Andrade e L'Esprit Nouveau, de Maria Helena Grembecki; Leituras em francês de Mário de Andrade, de Nites Therezinha Feres; e $O$ sequestro da dona ausente, de Telê Ancona Lopez. Em seguida, no segundo semestre de 1968, por meio de um projeto de Antonio Candido, o acervo de Mário de Andrade é adquirido para o Instituto de Estudos Brasileiros (IEB), sob os cuidados de Telê Ancona Lopez. Desde então, inúmeros trabalhos sobre o Modernismo e, particularmente, sobre Mário de Andrade, são feitos com base na riqueza documental de seu acervo e, no caso do escritor, na divulgação de sua correspondência e estudo de sua marginália. Atualmente, Telê coordena um Projeto FAPESP, Estudo do processo de criação de Mário de Andrade nos manuscritos de seu arquivo, em sua biblioteca, em sua correspondência, em sua marginália e em suas leituras. Desse projeto, tive acesso a duas teses de doutorado, de rico material informativo: PAULA, Rosângela Asche de. O expressionismo na biblioteca de Mário de Andrade: da leitura à criação. 2007. Tese (Doutorado em Literatura Brasileira) - Faculdade de Filosofia, Letras e Ciências Humanas da Universidade de São Paulo, São Paulo, 2007; e CARVALHO, Lilian Escorel. A revista francesa L'Esprit Nouveau na formação das ideias estéticas de Mário de Andrade. 2 v. 2008. Tese (Doutorado em Literatura Brasileira) - Faculdade de Filosofia, Letras e Ciências Humanas da Universidade de São Paulo, São Paulo, 2008. Dentro ainda da área de atuação do IEB, Marcos Antonio Moraes conduz um projeto de publicação da "correspondência reunida" de Mário de Andrade, cujo catálogo já está disponível em edição eletrônica e no site do IEB: <http://www.ieb.usp.br>. Como conjunto, esses esforços tornam certamente Mário de Andrade o artista e
} 
universitária veio de Roger Bastide, em texto sobre o poeta recolhido em Poetas do Brasil. ${ }^{36}$ Texto fino e de penetração insuperada, nele Bastide vai recuperar a partir de dentro, da própria estruturação formal dos poemas, os elementos que ligam subjetividade lírica e Brasil. Serão dois itens fundamentais: a dança, principalmente a dança de palavras em que o poeta se dissolveria sempre que seus poemas se aproximassem do clímax de seu desenvolvimento interno; e o diálogo, a busca do outro, e quando esse outro se ausenta ou é inalcançável, a meditação que desdobra um 'outro' de si mesmo, com quem o poeta elabora o mundo das coisas que lhe falta. Se excetuarmos a continuação dos textos de amigos e companheiros de Mário, de interessados em sua obra que escrevem textos mais genéricos, e de publicações de menor envergadura de poetas-críticos da Geração de 45, como os interessantes - mas panorâmicos - comentários de Péricles Eugênio da Silva Ramos e os textos de Ledo Ivo, cuja intenção é a polêmica, mas o resultado é o disparate e a desinteligência, do fim da década de 1940 temos de pular para meados da década de $1960 .{ }^{37}$ O período que na história intelectual brasileira abarca o começo do engajamento populista e a radicalização política não foi, por paradoxal que possa parecer, favorável à leitura de Mário de Andrade. Tudo indica que ficou a imagem de um "escritor difícil" lembrando que, para todos os efeitos, o "hermetismo" era expressão do beco sem saída do artista burguês - e sem um partidarismo explícito. O "espírito do tempo" não queria mediações entre a poesia e a busca do "povo", como demonstram os poemas hoje pouco legíveis da coleção Violão de rua, ${ }^{38}$ editados pelo Centro Popular de Cultura (CPC). Até mesmo Drummond era considerado difícil, o que fazia subir a cotação de um poeta mais imediato como Ferreira Gullar. ${ }^{39}$ De outro lado, o internacionalismo tecnocrático das novas vanguardas pouco queria saber de uma linguagem que não fosse autorreferente, e

intelectual cuja herança é mais bem cuidada, estudada e preservada na história da cultura brasileira. Um trabalho raro e inestimável, principalmente se não bloquear as possibilidades de interpretação e reflexão crítica sobre a sua obra.

${ }^{36}$ BASTIDE, Roger. Mário de Andrade [1940]. Poetas do Brasil São Paulo: Edusp/Duas Cidades, 1997.

${ }^{37}$ IVO, Ledo. Lição de Mário de Andrade [1952]. Poesia observada. São Paulo: Duas Cidades, 1978; MACHADO FILHO, Aires da Mata. Crítica de estilos. Rio de Janeiro: Agir, 1956; RAMOS, Péricles Eugênio da Silva. O Modernismo na Poesia. COUTINHO, Afrânio (Org.). A literatura no Brasil, v. 5, cit.; RAMOS, Péricles Eugênio da Silva. Poesia moderna. São Paulo: Melhoramentos, 1967; ALMEIDA, Fernando Mendes de. Mário de Andrade. São Paulo: Conselho Estadual de Cultura, 1965. Exceções são os textos que Manuel Bandeira continua publicando: BANDEIRA, Manuel. Mário de Andrade e a questão da língua. De poetas e poesia. Rio de Janeiro: Livraria São José, 1957; BANDEIRA, Manuel. Meu Amigo Mário de Andrade [1943/1960]. Andorinha, andorinha, cit.

${ }^{38}$ FÉLIX, Moacyr (Org.). Violão de rua. Rio de Janeiro: Civilização Brasileira, 1962. 3 v. (Cadernos do povo brasileiro).

${ }^{39}$ É o que lemos no depoimento de Armando Freitas Filho. Apud MASSI, Augusto (Org.). Artes e ofícios da poesia. Porto Alegre: Artes e Ofícios, 1991.p. 77. 
foi ler Mário quando a voga do formalismo acadêmico russo precisava de um objeto brasileiro. $^{40}$

A partir de 1960, como dizia, a crítica universitária se volta para a leitura da poesia de Mário de Andrade. Como exposição didática, pode-se dividir essa leitura acadêmica em duas correntes: uma que trabalha com a exegese da obra de Mário de Andrade, buscando principalmente explicar suas conexões internas, mas por vezes aberta, com bons e maus momentos, para as conexões entre a forma literária e o mundo não literário; e outra que busca entender as intenções e o posicionamento histórico da sua obra, atenta sobretudo às vinculações de classe do primeiro Modernismo, e que veriam na forma literária as contradições de um processo histórico especificamente brasileiro. A crítica de extração estruturalista de Luiz Costa Lima em Lira e antilira ${ }^{41}$ pouco pôde dizer sobre a poesia de Mário. Seguindo, na visão do crítico, uma tríade ascendente, do pior para o melhor, os poetas Mário, Drummond e Cabral, é neste último que se baseia para a leitura dos dois anteriores. Como se pode prever, da perspectiva do rigor construtivo da forma cabralina, Luiz Costa Lima só enxergou em Mário subjetivismo e falta de concisão. Já o trabalho de Maria Helena Grembecki, Mário de Andrade e L'Esprit nouveau ${ }^{42}$, segue os trilhos da disciplina "literatura comparada", particularmente sobre "fontes" e "influência". Assim, ficamos sabendo em detalhes como Mário elaborou sua primeira teoria poética com base no desenvolvimento da vanguarda francesa que se reunia em torno daquela revista. Enquanto essas duas obras contribuem apenas de modo secundário para este estudo, a obra seguinte, em termos cronológicos, da crítica que chamei "exegética”, é fundamental. Falo do estudo de Telê Porto Ancona Lopez, Mário de Andrade: ramais e caminho, de 1972. A autora procura mostrar como Mário de Andrade buscava organizar seu pensamento, estético e ideológico, que se desenvolve em momentos contraditórios da historia nacional e da história moderna, de um modo geral. Como define a autora: "Este é um trabalho que usa do enfoque histórico-ideológico mais do que o enfoque estético; deseja apresentar Mário de Andrade ante as possibilidades que tinha de organizar seu pensamento num todo harmonioso, capaz de conter uma teorização sobre a cultura brasileira" ${ }^{43} \mathrm{O}$

\footnotetext{
${ }^{40}$ CAMPOS, Haroldo de. Morfologia de Macunaíma. São Paulo: Perspectiva, 1973.

${ }^{41}$ LIMA, Luiz Costa. Lira e antilira (Mário, Drummond, Cabral) [1968]. Rio de Janeiro: Topbooks, 1995.

${ }^{42}$ GREMBECKI, Maria Helena. Mário de Andrade e L'Esprit Nouveau. São Paulo: IEB, 1969.

${ }^{43}$ LOPEZ, Telê Porto Ancona. Mário de Andrade: ramais e caminho. São Paulo: Duas Cidades, 1972. p. 13. Igualmente importante em termos de organização da pesquisa e do pensamento de Mário, agora sobre
} 
pesquisador e pensador do Brasil encontra linhas definidoras nesse estudo, que contribui decisivamente para a avaliação das relações entre subjetividade lírica e nação, pois faz o levantamento dos materiais de que dispunha o artista e expõe seu processo de reflexão intelectual. O passo propriamente estético será dado por Gilda de Mello e Souza, em seus vários estudos sobre Mário de Andrade. Especificamente sobre a poesia de Mário, há um comentário breve e poderoso em seu estudo sobre Macunaíma, de $1979 .{ }^{44}$ Em três páginas (53-54-55) Gilda lança as bases da crítica universitária posterior sobre o poeta: "Nas grandes meditações que representam uma das partes mais importantes de sua obra poética, o destino do Brasil se cruza e confunde com o destino pessoal do escritor, e os temas se organizam quase sempre aos pares, opondo-se simetricamente como as duas faces da mesma medalha". ${ }^{45}$ Aprofundando o tema, Gilda avança basicamente o programa de uma crítica dialética do poeta, ao enunciar a "fissura profunda que fere todos os setores da reflexão de Mário de Andrade, e se manifesta na poesia de maneira obsessiva pela oposição incessante das imagens". ${ }^{46}$ Em seu estudo específico sobre a poesia de Mário, Gilda recupera a relação entre $e u$ e nação como eixo central de sua lírica:

De fato, uma das referências do seu código poético é o Brasil, que ele procura apreender em vários níveis, nas variações semânticas e sintáticas da língua, nos processo tradicionais da poética erudita e popular, nas imagens e metáforas que tira da realidade exterior: a cidade natal onde viveu, o mundo muito mais amplo da geografia, da história, da cultura complexa do país. E como a outra referência do código é o eu atormentado do artista, a poesia resulta numa realidade ao mesmo tempo selvagem e requintada, primitiva a racional, coletiva e secreta, que não se furta ao exame, mas está sempre disfarçada por trás da multiplicidade das máscaras. ${ }^{47}$

Seguindo essa trilha, os principais estudos posteriores, que fecham até o momento essa linha de estudo da poesia de Mário que chamei de "exegética", procuraram mapear, desenvolver e relacionar as imagens com que se estrutura essa poesia. O primeiro é de Victor Knoll, Paciente arlequinada, ${ }^{48}$ um "Esboço de uma

a linguagem, é o estudo de PINTO, Edith Pimentel. A gramatiquinha de Mário de Andrade. São Paulo: Duas Cidades, 1990, trabalho cuja relevância aumenta quando se trata do estudo da obra poética do autor.

${ }^{44}$ SOUZA, Gilda de Mello e. O tupi e o alaúde [1979]. São Paulo: Duas Cidades/Editora 34, 2003.

${ }^{45}$ SOUZA, Gilda de Mello e. O tupi e o alaúde [1979], cit., p. 53.

${ }^{46}$ SOUZA, Gilda de Mello e. O tupi e o alaúde [1979], cit., p. 55.

${ }^{47}$ SOUZA, Gilda de Mello e. A poesia de Mário de Andrade [1988]. A ideia e o figurado. São Paulo: Duas Cidades/Editora 34, 2005. p. 31.

${ }^{48}$ KNOLL, Victor. Paciente arlequinada. Esboço de uma hermenêutica do imaginário na obra poética de Mário de Andrade. São Paulo: Hucitec, 1983. 
hermenêutica do imaginário na obra poética de Mário de Andrade", que, além da sistematização das imagens, mapeia os "versos re-versejados" e termina com uma instrutiva análise do complicadíssimo poema "Brasão". As “imagens" também aparecem no subtítulo do estudo de João Luiz Lafetá, Figuração da intimidade: imagens na poesia de Mário de Andrade, que foca seu estudo nos poemas de A costela do Grã Cão e Livro azul. O livro de Lafetá, cujo esforço de pesquisa é considerável, se apresenta particularmente confuso. Sua declaração de intenções é feita no nível da crítica histórica e materialista: "aquilo que proponho é que consideremos a poesia de Mário como um conjunto de reflexões (transpostas para o nível artístico) sobre os vários problemas que compuseram o universo ideológico da elite letrada da burguesia brasileira". ${ }^{49}$ Ao iniciar-se a leitura, contudo, o que se encontra são grandes generalizações teóricas. As relações entre "máscaras" e "intimidade" são estudadas segundo a tipologia de Northrop Frye, pelas conclusões da psicologia de Freud e de Jung, pelas teorias de Bachelard sobre a imaginação e pelo conceito que Octavio Paz elabora sobre a poesia moderna. O esforço de atualização teórica se impõe e mantém relativamente ocultos os pontos nevrálgicos da poesia de Mário no momento estudado: a indecisão política no plano histórico, a culpa e a autopunição no plano da sua consciência burguesa, a sexualidade ambivalente no plano amoroso. Estudioso constante de Mário, no entanto, Lafetá avança com mais segurança no estudo do Mário crítico, em que entram com proveito análises mais compreensivas e menos teorizantes de sua produção poética. ${ }^{50}$ Repositório de informações e comentários importantes, esses estudos sobre as imagens figuram como ponto distanciado, a que, contudo, permaneço atento na análise que proponho das relações dialéticas entre sujeito lírico e Brasil, relações cuja intuição de sua historicidade ${ }^{51}$ será, creio, o teste valorativo deste estudo.

\footnotetext{
${ }^{49}$ LAFETÁ, João Luiz. Figuração da intimidade imagens na poesia de Mário de Andrade. São Paulo: Martins Fontes, 1986. p. 15.

${ }^{50}$ LAFETÁ, João Luiz. 1930: a crítica e o modernismo. São Paulo: Duas Cidades/Editora 34, 2000. Ver também os textos "O Arlequim Estudioso" e "A Meditação sobre o Tietê" recolhidos em LAFETÁ, João Luiz. A dimensão da noite, cit.

51 “Articular historicamente o passado não significa conhecê-lo 'como ele de fato foi'. Significa apropriar-se de uma reminiscência, tal como ela relampeja no momento de um perigo. Cabe ao materialismo histórico fixar uma imagem do passado, como ela se apresenta, no momento do perigo, ao sujeito histórico, sem que ele tenha consciência disso. O perigo ameaça tanto a existência da tradição como os que a recebem. Para ambos, o perigo é o mesmo: entregar-se às classes dominantes, como seu instrumento. Em cada época é preciso arrancar a tradição ao conformismo, que quer apoderar-se dela. Pois o Messias não vem apenas como salvador; ele vem também como o vencedor do Anticristo. O dom de despertar no passado as centelhas da esperança é privilégio exclusivo do historiador convencido de que também os mortos não estarão em segurança se o inimigo vencer. E esse inimigo não tem cessado de
} 
Um ensaio que se encontra no juste milieu entre a exegese e a crítica histórica é "O poeta itinerante", 52 de Antonio Candido. Nele, o crítico faz uma análise fina de "Louvação da Tarde", último poema do "Tempo de Maria", do livro Remate de Males. A análise é formal, mas os movimentos com que ela trabalha desenham a história do espírito no Brasil. O poema "ocupa na sua obra uma posição-chave, porque representa a passagem da poesia mais exterior dos primeiros tempos de luta modernista para a poesia mais interior da última fase". ${ }^{53}$ As exterioridades de combate do Movimento Modernista se interiorizam: a liberdade psicológica se funde com o verso decassílabo branco, a máquina - o sujeito lírico do poema está andando de carro - se naturaliza e harmoniza com a natureza e o humano. O modernismo, enfim, passa ao moderno, o combate se consolida em conquista. Antonio Candido lê nesse poema um modo da maturidade estética e humana a que chegou a modernidade no Brasil. Não podemos jubilar, contudo. No livro em que Candido publica esse ensaio, $O$ discurso e a cidade, há uma seção para a crítica de poesia chamada "Fora do Esquadro", em que, além de Mário, se estuda a "Carta Marítima" de Sousa Caldas, o "Pomo do Mal" de Fontoura Xavier, a "poesia pantagruélica" da segunda geração romântica. Todos esses poemas apresentam perspectivas interessantes que o curso da vida mental brasileira não aproveitou conscientemente. Pensando, então, no caso de Mário, diante da adesão ao rigor construtivo abstrato, à tecnologia e à publicidade de que se nutriam as vogas concretista e tropicalista, essa maturidade do moderno foi mais um momento em que se apresenta um Brasil que poderia ter sido e não foi, e que deixou seu rastro na "Louvação da Tarde".

Ainda estamos em uma fronteira, mas agora entre close reading e crítica da ideologia, no texto de Roberto Schwarz, "O psicologismo na poética de Mário de Andrade" ${ }^{54}$ Trata-se de um texto do jovem Roberto Schwarz, anterior ao contato com a dialética adorniana, que corre nas águas mais lukacsianas do livro A sereia $e$ o desconfiado. As teorias poéticas de Mário, presas a polaridades estanques: "lirismotécnica, subconsciente-consciente, indivíduo-sociedade, ser-parecer" criariam uma

\footnotetext{
vencer" (BENJAMIN, Walter. Sobre o conceito de história. Magia e técnica, arte e política. Ensaios sobre literatura e história da cultura. São Paulo: Brasiliense, 1986. p. 224-225).

${ }^{52}$ CANDIDO, Antonio. O poeta itinerante. $O$ discurso e a cidade. São Paulo: Duas Cidades, 1998.

${ }^{53}$ CANDIDO, Antonio. O poeta itinerante, cit., p. 257.

${ }^{54}$ SCHWARZ, Roberto. O psicologismo da poética de Mário de Andrade. A sereia e o desconfiado. Rio de Janeiro: Civilização Brasileira, 1965.
} 
"prisão de noções", ${ }^{55}$ em que a síntese se encontraria para além delas: na emoção, na sinceridade total do artista, num vitalismo que extravasaria do poema para a vida. Atento mais à teoria poética do que à realização poética, Schwarz, como crítico da ideologia, vê na teorização de Mário um "círculo pré-dialético", 56 que engessaria categorias modernas, seria insensível à sua historicidade própria, à dialética do movimento histórico das formas, e cujo ponto de apoio seria o obscurantismo do subconsciente. Tomadas ao pé da letra as categorias da teoria poética de Mário, como se ele fosse, digamos, um Lukács ou um Croce brasileiro, nada se poderia acrescentar à crítica de Schwarz, e estaríamos lidando com um autor secundário, artista medíocre e mau teórico. Acontece que na florada de contradições em que se desenvolve a teorização, a crítica e a obra poética de Mário de Andrade, obscurantismo e esclarecimento estão por demais misturados, o que exige cautela e paciência crítica, pois, do contrário, as mediações entre a forma literária e processo histórico brasileiro se evolam sem ser compreendidas. Passamos de corpo inteiro para a crítica histórica e dialética em "Mário e o cabotinismo", de Anatol Rosenfeld. ${ }^{57} \mathrm{O}$ tema é o da sinceridade do artista, o que dá continuidade a um elemento do texto de Roberto Schwarz. A sinceridade seria uma arma desideologizante em sociedades de origem colonial, que desvestiriam a carga opressora e deixariam fluir uma naturalidade libertária. A sinceridade seria um valor aparentado com o da pureza ${ }^{58}$, e essa posição intelectual aproxima a obra de Mário às posições do primeiro nacionalismo alemão, de Herder principalmente, mas também do jovem Goethe. Contudo, a naturalidade popular da linguagem, se trabalhada conscientemente pelo artista, perde sua naturalidade e se torna artifício artístico. Essa dialética vai calar fundo no desenvolvimento intelectual e artístico de Mário, e a beleza de seu enfrentamento por nosso autor é bem apreendida por Rosenfeld: “É comovente acompanhar através da sua obra esta luta pela boa-fé, pela Wahrhaftigkeit - a 'verdadeiridade' subjetiva, virtude fundamental exigida por Nietzsche, virtude que se mantém, afirma e apura precisamente na verificação da simplicidade impossível e da duplicidade inevitável". ${ }^{59}$ A simultânea mediação e falta de mediação entre a demanda da verdade de um eu e a estruturação dúplice - má

\footnotetext{
${ }^{55}$ SCHWARZ, Roberto. O psicologismo da poética de Mário de Andrade, cit., p. 15.

${ }^{56}$ SCHWARZ, Roberto. O psicologismo da poética de Mário de Andrade, cit., p. 23. Esse texto foi discutido de modo interessante por LAFETÁ, João Luiz. 1930: a crítica e o modernismo, cit., p. 167-175.

${ }^{57}$ ROSENFELD, Anatol. Mário e o cabotinismo. Texto/Contexto. São Paulo: Perspectiva, 1969.

${ }^{58}$ ROSENFELD, Anatol. Mário e o cabotinismo, cit., p. 188.

${ }^{59}$ ROSENFELD, Anatol. Mário e o cabotinismo, cit., p. 190.
} 
estruturação, a bem dizer - de uma sociedade de origem colonial é posta com força por Rosenfeld. Em seu texto "Do cabonitismo", segue o crítico, Mário encontraria a melhor solução para o problema: tentando circunscrever tanto o genuíno quanto o artificial, tanto a demanda de sinceridade do poeta quanto sua vontade de se afirmar como ser social, o artista faz uma síntese em que o elemento cabotino é incorporado como momento fundamental da verdade total: "Esta é constituída tanto pela face como pela máscara". ${ }^{60}$ Formulação teórica e abrangente, em sua poesia essas questões se colocam com drama humano próprio, distante, como se verá, de uma possibilidade igualmente bem-sucedida de síntese. Passando, dialeticamente, do esforço de formulação de Mário de Andrade para o que de fora lhe fazia pressão, Rosenfeld é o primeiro a chamar pelo nome a mediação brasileira fundamental: o paternalismo, da qual outras, igualmente sinistras, derivam. Cacaso, em dois textos notáveis, dá continuidade a esse desvelamento de mediações históricas. ${ }^{61}$ Em "Atualidade de Mário de Andrade”, em que comenta a reedição de $O$ banquete, que chama com acerto de "filosofia brasileira das formas irregulares", 62 o nosso crítico, escolado na irreverência da poesia "marginal" da década de 1970 e já desiludido das superações brasileiras, dada a vitória completa da Ditadura Militar, finalmente chama as coisas pelo nome, em passagem notável:

Para entendermos e situarmos a postura modernista, um gênero de crítica que não larga o osso, é preciso ter presente um traço permanente e umbilical de nossa tradição cultural e literária: a sua propensão para o oficialismo, a literatura como apêndice da vida oficial. Nossa vida intelectual nasce e se desenvolve no sovaco do poder, atolada no paternalismo, que a reconhece e protege, além de ditar-lhe a duração e as regras do jogo. Durante tempos e tempos, nosso meio social pouco diferenciado não permitia a constituição autônoma e particularizada da atividade literária, que sobrevivia como parasita de outras mais prestigiadas socialmente, em geral àquelas ligadas à superestrutura administrativa. Sendo a literatura parte das convenções sociais, nem o seu público era específico, nem o escritor tinha papel definido ${ }^{63}$ [grifo do original].

\footnotetext{
${ }^{60}$ ROSENFELD, Anatol. Mário e o cabotinismo, cit., p. 195.

${ }^{61}$ CACASO (Antônio Carlos Brito). Atualidade de Mário de Andrade [1978] e Alegria da casa [1980]. Não quero prosa. São Paulo: Editora da Unicamp; Rio de Janeiro: Editora da UFRJ, 1997. Em sentido parecido, há um estudo das posições e situações políticas e sociais de Mário de Andrade, de caráter mais explicativo do que crítico, mas que se alinha, a meu ver, mais com a crítica histórica do que com a exegética, embora tenha características dos dois lados. Falo de DASSIN, Joan. Política e poesia em Mário de Andrade. São Paulo: Duas Cidades, 1978.

${ }^{62}$ CACASO. Atualidade de Mário de Andrade, cit., p. 155.

${ }^{63}$ CACASO. Atualidade de Mário de Andrade, cit., p. 157.
} 
O paternalismo seria para Mário, pequeno burguês que tirava seu sustento de seu trabalho intelectual, uma força de opressão, o que não lhe impede de buscar no paternalismo de matriz familiar e doméstica uma virtude de informalidade e afeição. Mais concretamente, essa condição do escritor punha em movimento as categorias históricas do $e u$ e do Brasil, em seus níveis literário e prático. A multiplicidade do sujeito lírico, da matéria histórica e dos materiais brasileiros tinha a função prática de conquistar liberdade para a vida mental e, por consequência, social: "Mário de Andrade encarnará, como nenhum outro escritor de seu tempo, este fenômeno transformador: um impulso de diferenciação, um combate para afirmar e assegurar a emancipação da atividade literária e do seu meio, até então praticamente atolado no pântano paternalista". ${ }^{64}$ As diversas idas e vindas nesse propósito, em que entram elementos heterogêneos, cujo aspecto avançado ou retrógrado é difícil de avaliar e precisa ser visto caso a caso, são um tema central no presente estudo das relações entre sujeito lírico e nação, e que serão abordadas, em diferentes faces, por meio da leitura de diferentes poemas em cada capítulo. Seguindo cronologicamente, temos em Mário de Andrade: exílio no Rio, de Moacir Werneck de Castro, ${ }^{65}$ o melhor perfil biográfico de Mário. O autor não se apresenta como crítico materialista, mas fazia parte do grupo de jovens comunistas cariocas que convivem pessoalmente com Mário de Andrade no Rio de Janeiro (entre 1938 e 1941) e que publicam a Revista Acadêmica. E de fato, a franqueza e a atenção para a contradição com que elabora o perfil do amigo, em uma biografia concisa e penetrante, deixam clara a herança do pensamento de esquerda. Werneck de Castro é o único comentador que desenvolve sem meias palavras os temas mais agudos da vida de Mário de Andrade, que migram com força para sua obra poética. Os fortes traços físicos de mulato, que Werneck de Castro elucida pela genealogia familiar, o elemento homossexual de sua vida amorosa, que compõe o quadro complexo de sua sexualidade ambivalente, a sua profunda indecisão política e ideológica em que a fé católica e a simpatia comunista entravam em pungente contradição. Imaginemos por um momento o sofrimento do homem mulato em uma sociedade cujo ideal era a brancura, do sujeito bissexual em sociedade machista, do pequeno burguês mais inteligente do que seus superiores numa sociedade dominada pelo favor. Contudo, esses sofrimentos não levaram Mário a se tornar nenhum "herói da resistência", pois nosso poeta usava pó de arroz, zelava pelo decoro e respeitava a autoridade. Antes, são as "fissuras

\footnotetext{
${ }^{64}$ CACASO. Alegria da casa, cit., p. 180.

${ }^{65}$ CASTRO, Moacir Werneck de. Mário de Andrade: exílio no Rio. Rio de Janeiro: Rocco, 1989.
} 
profundas" que ferem todos os setores de sua reflexão, como diz Gilda, que começam a ganhar concretude histórica e biográfica, com proveito para a compreensão de seus poemas.

Em comparação com a perspectiva histórica e materialista que vinha de Rosenfeld, Cacaso e Werneck de Castro, que se caracteriza pela amplitude de vistas e a disposição compreensiva, a crítica radical mais recente não deixa de marcar retrocesso, embora avance pontualmente em alguns setores da reflexão. Nas novas interpretações de Vinícius Dantas e Roberto Schwarz, sobressaem as limitações históricas, estéticas e ideológicas das vinculações de classe do modernismo dos anos 1920. Em ensaios que visam prioritariamente à revisão crítica de Oswald de Andrade, Vinícius Dantas procede a uma revisão do modernismo paulista como um todo. ${ }^{66}$ Retomando uma interpretação que está presente de modo difuso na obra crítica de Roberto Schwarz, ${ }^{67}$ e que posteriormente aparecerá em Duas meninas, Mário é lido em comparação com Oswald, e diante do individualismo sem recalques nem freios do autor de Pau-Brasil, o que ficaria evidente em nosso poeta seria o seu apego a formações sociais do atraso brasileiro: a família, o paternalismo, a responsabilidade, o sacrifício, sua tendência ao reformismo e à subalternidade. O objetivo, a meu ver, é a pesquisa e delimitação do "tamanho paulista" de Mário de Andrade, o que é uma perspectiva radical e crítica a seu modo, mas incompreensiva em tantos outros, como pretendo expor ao longo do meu trabalho. Veja-se, por exemplo, segundo o texto de Vinícius Dantas, como Mário, de certo modo, poria freio a aspectos libertários da vanguarda: “... a psicologia é fruto dos embates experimentais da vida, a se projetarem no passado, na subjetividade e na biografia individual. Aí se vê o quanto o inequívoco modernismo de Mário se acha às voltas com questões de cunho ético-psicológico, pois o inacabamento da formação brasileira o obriga a conciliar o ritmo sem fronteiras da vida interior individual com o paternalismo responsável". ${ }^{6}$ Fica em relevo, neste e no trecho seguinte de Roberto Schwarz - ao qual já chegaremos - um autor cuja inovação artística estaria excessivamente compromissada com o atraso, fazendo concessões e conciliações com o

\footnotetext{
${ }^{66}$ DANTAS, Vinícius. Entre "A Negra" e a Mata Virgem, cit., e DANTAS, Vinícius. Desmanchando o naturalismo: capítulos obscuríssimos da crítica de Mário e Oswald. Novos estudos. São Paulo, n. 57, jul. 2000.

${ }^{67}$ Aparece, por exemplo, em SCHWARZ, Roberto. O progresso antigamente [1981]. Que horas são? São Paulo: Companhia das Letras, 2006. p. 108-109.

${ }^{68}$ DANTAS, Vinícius. Entre "A Negra" e a Mata Virgem, cit., p. 106. Leia-se também a parte sobre Mário de Andrade, em ARANTES, Otília; ARANTES, Paulo. Moda caipira. Sentido da formação. Três estudos sobre Antonio Candido, Gilda de Mello e Souza e Lúcio Costa. São Paulo: Paz e Terra, 1997. p. 94 .
} 
seu meio. O comentário final de Roberto Schwarz ao ensaio "Outra Capitu", 69 pegando a trilha do "modo de ser" brasileiro captado por Antonio Candido em Memórias de um sargento de milícias, chega à questão modernista das potencialidades críticas da informalidade em relação à ordem artificial e artificiosa do país legal. Sua abordagem de Mário de Andrade se faz pela prosa. Entretanto, a perspectiva é montada com foco no uso que Mário faz da matéria e dos materiais brasileiros, de suas posições e intenções em relação a eles. O modernismo, que traz como potencialidade libertária o informal, se mete numa dialética problemática, pois reafirma de modo renovado "o molde familista, formas de autoridade e intimidade inclusive, [que] como que se substituía à política, a qual ficava no papel de uma superafetação dispensável". ${ }^{70}$ Essa pista do intimismo começa então uma viagem em favor da "imensa família virtual dos brasileiros", cujo trunfo é a positivação espiritualizada do paternalismo: "Os melhores sentimentos de que seria capaz o paternalismo levado ao limite dele mesmo, desvinculado de seus interesses materiais, mas cheio, ainda assim, dos cuidados correspondentes, ampliavam-se em escala amazônica, até as fronteiras do território e além". ${ }^{71}$ Esse bonapartismo do favor é mediado, nos diz o crítico, pela experimentação artística de ponta com nosso substrato pré-burguês, dando-lhe contraparte inconformista. Eis uma dialética difícil e confusa, em que a imersão, sempre segundo Schwarz, em nossos elementos pré-modernos dava força de atualização artística e abria horizontes práticos, ainda que questionáveis. A relação que segue nosso crítico é a da transgressão com a edificação. A transgressão se daria pelos motivos e gesticulações mais inesperados:

Trata-se de ostentar condicionamentos que se diriam constrangedores, como por exemplo bairrismos, entusiasmos colegiais, parentescos intrincados, deficiências de província, visões maleitosas, idiotismos populares, insubordinações filiais etc., e mais, de fazer praça deles no campo livre da reflexão contemporânea, onde funcionam como trunfos do pensamento adiantado, para não dizer subversivo. É como se um rio subisse a encosta do morro... ${ }^{72}$ [grifo do original].

Nosso modernismo, em parte especificamente Mário, em parte de modo geral, tomaria obscurantismo por esclarecimento, reafirmação da opressão por gesto libertário,

${ }^{69}$ SCHWARZ, Roberto. Outra Capitu. Duas meninas. São Paulo: Companhia das Letras, 1997. p. 134-144.

${ }^{70}$ SCHWARZ, Roberto. Outra Capitu, cit., p. 139.

${ }^{71}$ SCHWARZ, Roberto. Outra Capitu, cit., p. 140.

${ }^{72}$ SCHWARZ, Roberto. Outra Capitu, cit., p. 141. 
supondo encaminhar uma revolução quando faziam um grande desrecalque de classe dominante. Engrossando o rio que desce, enfim. Pensando ainda na prosa de Mário, Schwarz dá um passo além nos paradoxos de sua composição:

Voltando à prosa de Mário, para lhe apanhar o timbre transgressivo-edificante é preciso ter em conta as bandeiras particulares ao pé das coletivas, ou seja, as inflexões exibicionistas e adamadas, a que a autoridade dos motivos meritórios dá uma cobertura incômoda. Assim, alternando o experimentalismo vanguardista, a exaltação ginasiana, a superioridade professoral, a objetividade amadurecida, o interesse escuso, a devoção familiar, o domínio erudito das matérias etc., tudo sob a égide de uma visão abrangente e alta das necessidades da cultura nacional, Mário compunha um instrumento literário poderoso e estranho, profundamente ancorado nas realidades brasileiras, bem como na atualidade, capaz como quase nenhum outro de formular a experiência do país. ${ }^{73}$

A enumeração de características dessa passagem, que monta um mosaico muito complexo e difícil de entender, desnorteia. Em um primeiro momento, vemos o estilo e as posições de Mário de Andrade encetarem um movimento que se pode chamar de ideológico em sentido marxista, tratando por gerais interesses privados, e por privados interesses gerais. Na tentativa de organizar os elementos com que, segundo a enumeração de Schwarz, Mário trabalha, creio poder generalizar, porventura carregando um pouco nas tintas, duas ordens de características. Pela primeira ordem de enumeração de características, temos um narciso homossexual, com júbilos de menino e seriedade de mestre, profissional sério do conhecimento com cuidados maternos para os pupilos - em que entram indistintos e de cambulhada esnobismo e perversão, numa mistura protofascista. Uma segunda ordem de características parece apontar para o poder de desvelamento da obra literária, em que vemos o intelectual empenhado e artista pesquisador, de extraordinário poder de formalização, descobrindo e sistematizando toda a matéria e o material brasileiros que se lhe deparava. Como ficamos? Entre o "tamanho paulista" do Mário da década de 1920, pequeno-burguês e provinciano, subordinado e cheio de recalques, buscando compensações em uma atualização artística e intelectual onívora, e o exame das obras poderosas onde tudo isso se realiza parece haver um espaço que a reflexão de Schwarz não cobre, salvo engano, embora enuncie os termos. É possível que certo clima de "Memorial Mário de Andrade" que paira (ainda paira?) no ambiente intelectual paulista favoreça, da parte da crítica radical, o

\footnotetext{
${ }^{73}$ SCHWARZ, Roberto. Outra Capitu, cit., p. 142.
} 
desvelamento crítico da parte que a antiga atitude de conservação e zelo do "grande Autor" propositadamente evitava, além da relativa antipatia. No entanto, isso importa menos do que os pontos em que toca o nosso maior crítico literário. Contudo, a enumeração simplesmente aditiva de características dá à passagem de Schwarz um aspecto de formulação incrustada, cuja dimensão das ambivalências deixa em dúvida qual será a natureza da dialética que põe em movimento essas características, que parecem criar um labirinto de obscurantismo e esclarecimento. Algo do movimento subjetivo que preside à organização da forma literária em relação a sua matéria histórica e seus materiais, e que tem relativa independência em relação às posições e mesmo às intenções pessoais do autor, escapou ao crítico. É nesse sentido que o presente estudo busca a relação entre o eu lírico e o Brasil, no intuito de desenvolver em que medida se pode apreender essa contraditoriedade e explicar a relação entre seus termos e sentidos antagônicos.

\section{Modernismo, Formação, Lírica e Sociedade}

As contradições em que se inscrevem o sujeito lírico e o Brasil na poesia de Mário de Andrade perfazem o caminho da poesia modernista brasileira, de 1922 a 1945. Mais do que isso, a poesia de Mário de Andrade acumula problemas poéticos e extrapoéticos ao longo de sua trajetória e busca solucioná-los em poesia e em formulações de plataformas poéticas. Como conjunto dentro do Movimento Modernista, a poesia de Mário de Andrade não é somente uma oeuvre, mas também um legado de problemas e soluções organizados, que pode ser percebido e analisado pela crítica, mas pode igualmente operar como legado dentro da poesia modernista. Assim, principalmente Manuel Bandeira e Carlos Drummond de Andrade - interlocutores de vida inteira de Mário - incorporam descobertas, experimentos e/ou perspectivas da poesia de Mário em momentos decisivos de suas obras poéticas, como apontarei ao longo desta tese, sobretudo na análise de "Noturno de Belo Horizonte", de Mário, no Capítulo IV. Além disso, a intensificação do diálogo de Mário com Drummond no início da década de 1940, com discussões sobre o valor de conjunto da obra de Mário e das relações entre poesia e posição política, aponta para uma presença decisiva do poeta paulista do livro igualmente decisivo de Drummond de 1945, A rosa do povo. Esse 
capítulo final da obra de Mário, em que ela é legada a um outro, Drummond, no caso, é o tema da conclusão desta tese.

Como acúmulo de problemas que podem ser compartilhados e cujas soluções adquirem um valor coletivo, o caminho e o sentido da poesia de Mário de Andrade se inserem numa questão central da crítica literária brasileira e do pensamento sobre o Brasil: o conceito de formação. Esse conceito decisivo atua como uma busca de "linhas evolutivas mais ou menos contínuas" em nosso quadro social e artístico, como uma "aspiração coletiva de construção nacional" e/ou como um sistema literário constituído por autor-obra-público, em que há um "processo cumulativo de articulação com a sociedade e adensamento artístico" ${ }^{74}$ Embora a formação, como conceito especulativo ou plataforma literária, esteja presente em momentos decisivos em nossa história literária, principalmente nos momentos equivalentes ao Romantismo no século XIX (1836-1870) e ao Modernismo no século XX (1922-1945) ${ }^{75}$ e, nesse caso, o tema desta tese esteja vinculado a um desses momentos decisivos, a perspectiva do crítico não pode ignorar o estado atual do conceito. Procedendo a essa avaliação contemporânea do conceito de formação, escreve Roberto Schwarz:

No momento, o sistema literário nacional parece um repositório de forças em desagregação. Não digo isso com saudosismo, mas em espírito realista. O sistema passa a funcionar, ou pode funcionar, como algo real e construtivo na medida em que é um dos espaços onde podemos sentir o que está se decompondo. A contemplação da perda de uma força civilizatória não deixa de ser civilizatória a seu modo. Durante muito tempo tendemos a ver a inorganicidade, e a hipótese de sua superação, como um destino particular do Brasil. Agora ela e o naufrágio da hipótese superadora aparecem como o destino da maior parte da humanidade contemporânea, não sendo, nesse sentido, uma experiência secundária. ${ }^{76}$

Ou seja, a formação continua a ser uma perspectiva válida, desde que se abandonem as suas hipóteses superadoras e venham à tona os processos de sua desagregação. Salvo engano, há uma analogia entre o estado atual do conceito de formação, que avalia retrospectivamente o seu fracasso, embora não reduza a sua importância analítica, e o

\footnotetext{
${ }^{74}$ As citações são do texto de ARANTES, Paulo Eduardo. Providências de um crítico literário na periferia do capitalismo. In: ARANTES, Otília Beatriz Fiori; ARANTES, Paulo Eduardo. Sentido da formação. Três estudos sobre Antonio Candido, Gilda de Mello e Souza e Lúcio Costa. São Paulo: Paz e Terra, 1997. p. 11,13 e 21 , respectivamente [grifo do original].

${ }^{75}$ CANDIDO, Antonio. Literatura e cultura 1900-1945. Literatura e sociedade. Rio de Janeiro: Ouro sobre Azul, 2008. p. 119.

${ }^{76}$ SCHWARZ, Roberto. Os sete fôlegos de um livro. Sequências brasileiras. São Paulo: Companhia das Letras, 1999. p. 58.
} 
modo como Mário de Andrade avalia em seus últimos anos de vida a sua obra literária, encarando também ele a sua obra e atuação pela perspectiva do fracasso, embora tampouco reduza a importância exemplar de sua derrota. Assim, ao ponto de vista que procuro compor subjaz uma concepção de história da literatura brasileira específica: a de que ela já cumpriu seu ciclo histórico projetado no Romantismo, em que a literatura equivaleria no mundo do espírito ao que foi a Independência no plano político. ${ }^{77}$ Avaliar o que restou desse ciclo, cujas aspirações não se realizaram plenamente, mas que legou uma literatura organizada, coerente e com momentos de primeira grandeza ${ }^{78}$ é, a meu ver, um programa da crítica radical, histórica, materialista e dialética, cuja linhagem remonta ao momento de esclarecimento radical que foi o programa da formação. ${ }^{79} \mathrm{O}$ procedimento aqui levado a cabo, então, mimetiza a perspectiva de análise: se o pensamento vai do fim para o começo, a cronologia da obra também pode ser subvertida, e o início da análise pode partir de sua última expressão poética. A própria obra poética de Mário de Andrade nos orienta nesse sentido, como estamos vendo.

Essa questão formativa, por fim, traz a relação fundamental que subjaz a toda esta tese - a da relação entre lírica e sociedade. O texto clássico sobre o tema, como se sabe é "Palestra sobre Lírica e Sociedade", de Adorno. ${ }^{80}$ Nesse texto, para expô-lo resumidamente apenas na questão que mais nos interessa neste momento, o pressuposto da forma da lírica é a individuação da sociedade moderna: "a própria solidão da palavra lírica é pré-traçada pela sociedade individualista e, em última análise, atomística, assim como, inversamente, sua capacidade de criar vínculos universais [allgemeine Verbindlichkeit] vive de sua individuação". ${ }^{81}$ Dado esse pressuposto histórico-social, o processo reflexionante do sujeito individuado e a objetividade da sociedade objetivada podem ser sublimados na linguagem da lírica: “em cada poema lírico devem ser encontrados, no médium do espírito subjetivo que se volta sobre si mesmo, os

\footnotetext{
77 CANDIDO, Antonio. Uma literatura empenhada. Formação da literatura brasileira. Belo Horizonte: Itatiaia; São Paulo: Edusp, 1975. v. I, p. 26.

${ }^{78}$ Uma avaliação desse processo se lê com proveito em SIMON, Iumna Maria. Considerações sobre a poesia brasileira em fim de século. Novos estudos. São Paulo, n. 55, p. 27-36, nov. 1995.

79 "No momento em que a formação nacional entra em crise, ela continua a existir como tradição, sentimento da reciprocidade entre os diferentes grupos, como obrigação moral entre as partes, como uma espécie de resumo da ideia de civilização. A ideia de nação pode se enfraquecer sem que a ideia de formação perca a sua vigência civilizadora" (SCHWARZ, Roberto. Crítica de intervenção. Rodapé. Crítica da literatura brasileira contemporânea. São Paulo: Nankin, n. 3, p. 21, nov. 2004).

${ }^{80}$ ADORNO, Theodor W. Palestra sobre lírica e sociedade. Notas de literatura I. São Paulo: Duas Cidades/Editora 34, 2003. p. 65-89.

${ }^{81}$ ADORNO, Theodor W. Palestra sobre lírica e sociedade, cit., p. 67.
} 
sedimentos da relação histórica do sujeito com a objetividade, do indivíduo com a sociedade" ${ }^{82}$ Somente nesse processo de diferenciação social muito avançada é que a lírica pode, por um processo de reflexão e autonomização, ser tanto mais social quanto menos o tema social nela desponta: "Esse processo de sedimentação será tanto mais perfeito quanto menos a composição lírica tematizar a relação entre o eu e a sociedade, quanto mais involuntariamente essa relação for cristalizada, a partir de si mesma, no poema". ${ }^{83}$ Ora, são justamente os processos histórico-sociais de individuação, diferenciação social e autonomia da arte que faltam no Brasil, como já acompanhamos em dado momento desta Introdução. Assim, o modo como sociedade e lírica se constituem no Brasil exige que o texto de Adorno seja dialetizado em seus pressupostos fundamentais. Como argumentou Iumna Simon, ${ }^{84}$ poesia e sociedade no Brasil são mais porosos entre si do que nos centros da modernidade europeia. Como desenvolverei ao longo desta tese, a pouca diferenciação das esferas sociais no Brasil e a perpetuação de estruturas sociais, políticas e psicológicas herdadas do nosso liberal-escravismo paternalista $^{85}$ do século XIX tornava a presença de pressupostos sociais, conceitos modernos e formas literárias algo diferente em solo brasileiro. Assim o trânsito de lírica e sociedade, menos mediado no Brasil, gerava problemas poéticos específicos, que somente poderiam ser configurados por meio da reflexão dos poetas sobre as formas europeias e a matéria local. Nesse quadro complexo e conflitante, a poesia de Mário de Andrade buscava uma ordenação da forma poética que implicava por analogia a ordenação de categorias como o eu e o Brasil, dentro de um movimento renovador e formativo como o Modernismo.

\section{Resumo dos Capítulos}

De acordo com a constelação de problemas que estamos acompanhando, o Capítulo I desta tese, "Uma Positividade Agônica", recompõe o modo como Mário de Andrade faz o balanço da própria obra, organizando uma última vez e julgando-a severamente. Isso ocorre em textos como "O Movimento Modernista" e O banquete, que serviram como textos de apoio, e, principalmente, em "A Meditação sobre o Tietê"

\footnotetext{
${ }^{82}$ ADORNO, Theodor W. Palestra sobre lírica e sociedade, cit., p. 72.

${ }^{83}$ ADORNO, Theodor W. Palestra sobre lírica e sociedade, cit., p. 72.

${ }^{84}$ SIMON, Iumna Maria. Considerações sobre a poesia brasileira em fim de século, cit., p. 30.

${ }^{85}$ A expressão "liberal-escravismo paternalista" está em SCHWARZ, Roberto. Ao vencedor as batatas. São Paulo: Duas Cidades/Editora 34, 2000. p. 112.
} 
$(\mathrm{LP})^{86}$. Analiso esse poema em alguns de seus momentos fundamentais para enfatizar problemas, perspectivas e soluções que emergem de sua obra poética como conjunto e tomam corpo em seu último poema.

O Capítulo II, "Verdade Psicológica ou os Limites do Sujeito Lírico", configura o problema da subjetividade na poesia de Mário de Andrade, operando com as categorias de sujeito lírico - imanentemente literária - e de individuação social categoria extraliterária. A dialética entre sujeito lírico e individuação social é seguida por meio de um corte transversal em sua obra poética, em que a escolha dos poemas se refere a momentos definidores do sujeito lírico e a momentos-limite de seu processo constitutivo, como a dança e a maleita. Assim, são analisados os poemas "Eu sou Trezentos..." (RM), "Momento" (CGC), "Danças" (RM) e "Rito do Irmão Pequeno" (LA).

O Capítulo III, "O Amor", desenvolve a questão da subjetividade do poeta no tema da lírica amorosa. Visei aqui o mapeamento da complexidade amorosa de Mário de Andrade. De suas disposições de amor físico, eros, até os vários graus de seu amoramizade, filia, passando pela renúncia presente no amor platônico. Suas disposições amorosas são, como veremos, modos de o poeta relacionar-se consigo e com o "outro" e, nessas disposições e em sua linguagem poética, surge inesperadamente o Brasil com suas determinações e seu destino. Os poemas analisados são "Carnaval Carioca" (CJ), "Paisagem n. ${ }^{\circ}$ 3" (PD), “Amar Sem Ser Amado, Ora Pinhões!" (RM), "Poemas da Negra" (RM) e "Girassol da Madrugada" (LA).

No Capítulo IV, "Sentimento Religioso da Vida", é estudado o modo como Mário desenvolve em sua poesia a sua religiosidade. Inicialmente de um catolicismo fervoroso, sua religiosidade se encaminha em sua obra poética cada vez mais para uma comunhão com a vida, para uma entrega religiosa aos atos de uma vida humana e social mais fraterna. Essa passagem das atitudes da devoção católica para as disposições de uma fraternidade religiosa é seguida nos poemas "Religião" (PD), "Louvação Matinal" (RM), "Louvação da Tarde" (RM) e "Noturno de Belo Horizonte" (CJ).

O Capítulo V, "O Engajamento Difícil", último da tese, desenvolve o modo como o poeta, em sua relação com o "outro" social, elabora possibilidades de engajamento social. A disposição fraterna, estudada no capítulo anterior, se radicaliza e

\footnotetext{
${ }^{86}$ Entre parêntesis coloco o título do livro de poemas: Paulicéia desvairada (PD), Losango cáqui (LC), Clã do jabuti (CJ), Remate de Males (RM), O carro da miséria (CM), A costela do Grã Cão (CGC), Livro azul (LA), Lira paulistana (LP).
} 
se transforma em tomada de posição política de esquerda, de inesperadas consequências poéticas. Acompanho esse caminho pela análise dos poemas: "Ode ao Burguês" (PD), "Colloque Sentimental" (PD), "Dois Poemas Acreanos" (CJ) e "O Carro da Miséria" $(\mathrm{CM})$.

Por fim, na Conclusão, procedo não somente a um balanço dos temas estudados ao longo da tese mas também me ocupo do legado da obra poética de Mário de Andrade dentro do Movimento Modernista. Nesse sentido, recupero o diálogo poético e político de Mário com Drummond entre os anos 1942 e 1945, estudando as relações entre o conjunto da poesia de Mário e o livro A rosa do povo (1945), de Drummond. Termino a Conclusão da tese com a análise do poema "Mário de Andrade desce aos Infernos", presente nesse livro de Drummond. 


\section{CAPÍTULO I - UMA POSITIVIDADE AGÔNICA}

... uma aurora que não deu dia. Mário de Andrade. O Aleijadinho

A imagem de Mário de Andrade que a posteridade guardou foi a de sua atuação no Movimento Modernista da década de 1920, de Paulicéia desvairada (1922) a Macunaíma (1928). No entanto, o próprio Mário de Andrade já avaliou esse período em sua obra posterior, afastando-se e de certa forma desvinculando-se dele. A partir de Remate de Males (1930), o poeta se distancia dos elementos positivos do Modernismo nacionalista, dispondo os resultados poéticos de suas pesquisas brasileiras de modo mais pessoal, mais denso e mais crítico. E quanto mais a história brasileira tirava o chão do poeta, mais a sua poesia se acirrava e aumentava a voltagem crítica, chegando ao grande momento crítico da década de 1940, com "O Movimento Modernista", $O$ banquete e "A Meditação sobre o Tietê". É necessário notar, no entanto, que o aumento de problematicidade e dramaticidade nessa obra poética não altera a sua natureza. Não se trata de dizer que o sujeito lírico, a linguagem e a visão de mundo de Paulicéia desvairada são os mesmos de "A Meditação sobre o Tietê", mas, sim, que um mesmo conjunto de propostas poéticas e procedimentos subjetivos se mantém e se recompõe em contextos diferentes. Serão estruturas profundas da poesia de Mário de Andrade que irão se reconfigurar em conjunturas diversas, sem que sua natureza seja abalada. É como se disséssemos que a música pode mudar de andamento, de melodia e mesmo de ritmo, mas são sempre as mesmas cordas que estão soando. Assim, Mário se distancia e avalia criticamente o Modernismo nacionalista não porque sua subjetividade ou sua linguagem poética tenham passado por uma modificação fundamental. Ao contrário, o Modernismo nacionalista, por um lado, se esgota em fórmulas prontas na poesia brasileira do final da década de 1920 e, por outro, os desfechos políticos da crise da República Velha já não permitem um nacionalismo universalmente integrador. $O$ interlocutor da poesia de Mário muda, e ela reflete em si essa mudança. A cada passo, contudo, a poesia de Mário recupera e avalia os passos anteriores, fazendo com que momentos dessa obra poética não sejam momentos de mudança fundamental, mas de uma constante revisão de si. Não é de estranhar, então, que as últimas obras do poeta, que já pressentia a morte, sejam grandes revisões críticas. Por isso, “A Meditação sobre 
o Tietê" não apenas é seu maior e mais importante poema mas é também uma revisão de conjunto de sua poesia.

Pode-se então depreender o sentido e o significado do conjunto da obra poética mariodeandradiana a partir dessa sua última configuração. É o modo como o próprio poeta faz a apresentação crítica de sua poesia e desenha a sua própria imagem para a posteridade. Houvesse nesse procedimento a conhecida autocomplacência medalhônica dos homens velhos e consagrados, acompanhá-lo seria uma injustificável reafirmação da vaidade literária do autor. Porém, a agudeza do poeta para consigo e com sua obra em “A Meditação sobre o Tietê" é drasticamente antimedalhônica ${ }^{87}$ e exibe uma radicalidade que raramente foi recuperada pela fortuna crítica.

\section{Revisão da Obra}

O poema é uma grande meditação do eu lírico situado sobre a ponte das Bandeiras, acompanhando o curso das águas do rio Tietê, nele vendo o seu destino e remontando sua vida e trajetória. A água "pesada e oliosa" do Tietê vai trazer de volta, e a seu modo trazer à tona, o que restou da poesia de Mário em um momento em que o poeta sente sua obra como terminal. A "Paulicéia", a grande cidade moderna dos seus primeiros versos modernistas, é vista, logo no começo do poema, em negativo:

É a cidade... É a emaranhada forma

Humana e corrupta da vida que muge e se aplaude.

E se aclama e se falsifica e se esconde. E deslumbra.

(versos 16-18)

E a ausência do élan vital no Brasil é sentido com um doloroso espanto, em momento posterior do poema, retomando uma imagem cara a seu primeiro livro modernista: "Qué-de as Juvenilidades Auriverdes!” (v. 165). A força construtiva sentida em Paulicéia desvairada é vista em seu negativo, como derrota e amargura. São ainda os primeiros temas poéticos de Mário retornando nas águas sujas do rio. A grande ausência

\footnotetext{
${ }^{87}$ Sobre o tema do medalhão, é interessante notar a posição declarada de Mário a esse respeito. Quando ele começa sua correspondência com Fernando Sabino, no começo de 1941, escreve: "Seria estúpido eu não saber que sou 'consagrado'. Só os esforços, os esperneios, os papelões que faço pra não virar medalhão duma vez, você nem imagina" (Carta de 25 de janeiro de 1941. SABINO, Fernando; ANDRADE, Mário de. Cartas a um jovem escritor e suas respostas. Rio de Janeiro; São Paulo: Editora Record, 2003. p. 20).
} 
na "Meditação" é o livro Losango cáqui, a que o poema não se refere sequer uma vez. Isso ocorre, certamente, porque ele deriva fundamentalmente dos aspectos alegres da Paulicéia..., de anotações líricas de três meses de um "juvenil auriverde", ou seja, justamente desse aspecto que o poeta não consegue mais vislumbrar nas águas do seu Tietê. De Clã do jabuti não aparecem referências explícitas, mas procedimentos poéticos que surgem nesse seu terceiro livro modernista, o único programaticamente nacionalista. Esses procedimentos são de matriz mais oratória: são as interpelações e a "pregação". O trecho da "Meditação" que começa: "A culpa é tua, Pai Tietê?..." e segue por “Onde estão os amigos? Onde estão os inimigos?" (versos 92-106) retoma a forma de interpelação de "Carnaval Carioca": "Meus Deus.../Onde que jazem tuas atrações?" (todo o trecho neste poema vai dos versos 170-204). A "pregação", que em Clã do jabuti é de caráter nacionalista e fraterno, e principalmente em "O Poeta Come Amendoim" e no final de "Noturno de Belo Horizonte", 88 aparece na "Meditação" no trecho que começa com “Tu és demagogia...” (versos 107-131), mas já não se trata de uma pregação fraterna, antes será uma pregação negativa, uma "deprecação" contra a natureza destrutiva e mesquinha da ambição das águas do rio, da Paulicéia, da modernidade brasileira. Todos esses elementos são retomados em negativo, mas estão presentes. Como exporei mais adiante, essa presença em negativo possui um caráter de resistência poética, com função específica na estruturação de "A Meditação sobre o Tietê". Por ora, basta enfatizar que os três primeiros livros de poemas modernistas de Mário, que visavam construir posivitivamente uma modernidade brasileira, são retomados por um viés negativo, invertendo e rechaçando a adesão construtiva e nacionalista de então.

A partir de Remate de Males, livro de feição mais negativa, assim como os que o seguem, as recuperações não precisam ser invertidas, e obedecem a um procedimento de transposição. De Remate de Males, vemos voltar a questão racial da "brancura", a questão cultural das tradições e do pertencimento nacional do poema "Improviso do Mal da América", no verso "Contágios, tradições, brancura e notícias" (v. 63), e o conhecido poema "Eu sou trezentos..." é retomado no verso "desque me fiz poeta e fui trezentos..."

\footnotetext{
${ }^{88}$ Ver Capítulo IV desta tese. Há pregação propriamente religiosa em "Carnaval Carioca" (versos 214230), mas ela participa de uma emoção religiosa contextualizada por uma irrupção momentânea da sensação de pecado e ausência de Deus nos prazeres do carnaval. A pregação nacionalista e fraterna, ao contrário, é um elemento fundamental do livro. Ela subsume a religião em um componente religiososacrificial para a boa integração sociocultural brasileira e sua confraternização universal com as demais nações do mundo.
} 
(v. 269). Junto deste último verso, o poeta ainda evoca seu momento anterior ao Modernismo:

$$
\begin{aligned}
& \text { Desque me fiz poeta e fui trezentos, eu amei } \\
& \text { Todos os homens, odiei a guerra, salvei a paz! }
\end{aligned}
$$

(versos 269-270)

São palavras que trazem à memória o livro Há uma gota de sangue em cada poema, de 1917, quando Mário seguia a linhagem do internacionalismo pacifista do "unanimismo ", ideal de união fraterna de todos os homens pelo amor mútuo, cuja linhagem poética tem origem em Victor Hugo, se assenta em Walt Whitman, tem seu fastígio com Jules Romains, que lhe dá o nome, e Émile Verhaeren, e exerce influência notória em Apollinaire. $^{89}$ É o ideal político-social que perpassa toda a obra de Mário, especificando-se cada vez mais no contato com a matéria brasileira, até se revelar impossível, como tentarei mostrar no Capítulo V desta tese.

Prosseguindo a revisão: de "Carro da Miséria", longo poema feito e refeito por Mário, cujas redações fundamentais ocorrem no fim de 1930 e fim de 1932, com uma última revisão no fim de 1943, há a recuperação da letra e do espírito. Da letra no verso: "Me sinto o pai Tietê! oh força dos meus sovacos!" (v. 84), que recupera quase literalmente os versos 13-14 da parte I de "O Carro da Miséria", e a "cauda de pavão de mil olhos de séculos" (v. 190) da "Meditação" é uma transposição integral do verso 22 da parte XV. E do espírito da postura autodestrutiva dos versos da "Meditação":

Eu nem tenho o direito mais de ser melancólico e frágil,

Nem de me estrelar nas volúpias inúteis da lágrima!

(versos 47-48)

Que recuperam a postura dos seguintes versos de "O Carro da Miséria":

No fundo eu choro como um mamote safado

No fundo eu choro como um safadíssimo chupim

Parte VIII (versos 21-22)

\footnotetext{
${ }^{89}$ Sobre a poesia pré-modernista de Mário, ver LOPEZ, Telê Porto Ancona. Mário de Andrade: ramais e caminho. São Paulo: Duas Cidades, 1972. p. 21-36.
} 
De A costela do Grã Cão, livro de 1941, há três referências na "Meditação". Mário chama essa obra de "terrível [...] muito brutal e pessoalmente detestável", 90 possivelmente pela enorme tristeza da primeira parte, e pelo hermetismo da linguagem e a postura agressiva do sujeito lírico da segunda. Da primeira parte, há o aproveitamento do verso "pra lá da serra caxingam os dinossauros", do poema "Momento" (verso 8) no verso 12 da "Meditação": "Ruas, ruas, por onde os dinossauros caxingam". Mas é da segunda parte, denominada "Grã Cão de Outubro", que "A Meditação sobre o Tietê" recupera mais imagens e expressões: as "altas torres" do seu verso 8 estão no poema "Dor", cujo verso 6 é: "Eu venho das altas torres, venho dos matos alagados", o verso 14 da "Meditação": "Os bichos blau e os punidores gatos verdes", recupera os "bichos blau" de "Brasão" (v. 12) e os "gatos verdes" estão no poema "Os Gatos (a)" (último verso). O "Boi Paciência", que aparece na "Meditação" nos versos 61 e 75 retomam novamente "Brasão" (v. 26).

De Livro azul, “onde por minha própria crítica está o que de melhor fiz em poesia", ${ }^{91}$ Mário recupera as suas formas de amar. O poema "Rito do Irmão Pequeno" é comentado pela "Meditação" nos versos 264-266:

\section{Eu já amei}

Contigo, Irmão Pequeno, no exílio da preguiça elevada, escolhido

Pelas águas do túrbido rio do Amazonas, meu outro sinal.

E, de "Girassol da Madrugada", ele recupera a rememoração dos "amores eternos", expostos ao final da parte $\mathrm{V}$ desse poema. A "Meditação" retoma tanto a forma da enumeração dos amores quanto parte das referências amorosas. O fim da parte $\mathrm{V}$ de “Girassol da Madrugada" diz:

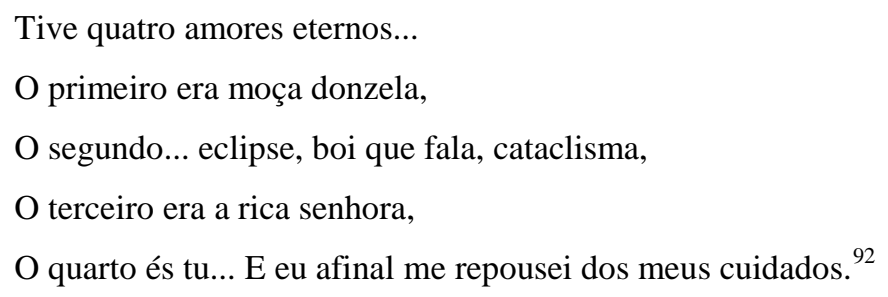

(versos 5-8)

\footnotetext{
90 Carta a Alphonsus de Guimarães Filho, citada em nota em MORAES, Marco Antônio (Org.). Correspondência Mário de Andrade \& Manuel Bandeira. São Paulo: Edusp/IEB, 2001. p. 658.

$91 \mathrm{Na}$ mesma carta a Alphonsus de Guimarães Filho, em MORAES, Marco Antônio (Org.). Correspondência Mário de Andrade \& Manuel Bandeira, cit., p. 658.

${ }^{92}$ Há análise deste poema, e deste trecho especificamente, no final do Capítulo III desta tese.
} 
E os versos 261-264 de "A Meditação sobre o Tietê":

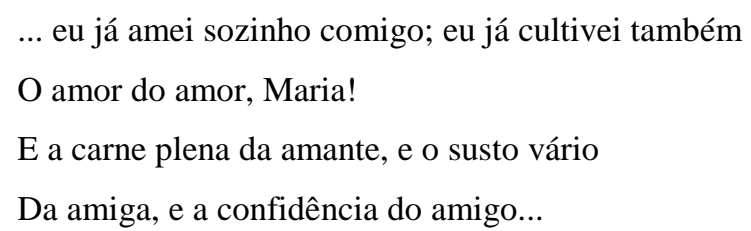

Por ora, não nos perguntemos quem são esses amantes e quais são essas formas de amor, que procurarei desenvolver no Capítulo III, mas atentemos para a convergência do conjunto da obra poética mariodeandradiana para o seu último poema. Mesmo de Lira paulistana, obra final em que se insere "A Meditação sobre o Tietê", o poeta incorpora um verso do poema “Agora eu quero cantar...”. Mário recupera desse poema o mote de esperança consoladora, mas em chave amargamente negativa. $\mathrm{O}$ poema “Agora eu quero cantar..." narra o sofrimento e a irrelevância da vida de um operário, e seu mote, que se modifica um pouco ao longo do poema, é assim em sua primeira aparição, no final da $3^{\mathrm{a}}$ estrofe:

- Havia de ter, decerto,

Uma vida bem mais linda

Por trás da serra, pensou.

(versos 36-38)

E, na "Meditação", os versos 309-311:

Rio, meu rio... mas porém há-de haver com certeza

Outra vida melhor do outro lado de lá

Da serra!

Espero, neste momento, após tantas enumerações atomizadas, ter demonstrado que "A Meditação sobre o Tietê" faz uma revisão praticamente completa da obra poética de seu autor, que pode ser acompanhada explicitamente por meio de citações literais ou quase literais de seus poemas, fazendo o próprio Mário uma apresentação crítica de sua poesia na hora em que sentia que sua obra chegava ao seu momento conclusivo. 
"A Meditação sobre o Tietê" e "O Movimento Modernista"

“A Meditação sobre o Tietê”, por ser uma revisão lírica de toda sua obra poética, atuando em sua poesia de modo equivalente a "O Movimento Modernista" no plano da crítica, revela aspectos fundamentais da lírica mariodeandradiana e se erige em suma. $\mathrm{O}$ ritmo das águas do rio é eminentemente destrutivo, e, no entanto, há nos versos uma indignação e uma amargura comovidas que parecem oferecer resistência a esse ritmo, resistência tanto mais dramática quanto mais ela é vencida pelo curso do rio, cujo destino é a corrupção da terra dos homens, o contágio da vida danificada. Um dos elementos fundamentais da grandeza do poema é a falta de sentimentalismo, de condescendência do poeta consigo, unida à visão de si mesmo como parte de uma configuração histórica. Com o eu lírico, é todo o "Movimento Modernista" que passa por um processo de expiação ao longo do poema.

A forma poética de "A Meditação sobre o Tietê" tem um alcance extraordinário. O verso livre modernista se transforma em versículo solene, impregnado de uma religiosidade laica. O sentimento religioso da vida ${ }^{93}$ imprime significação aos seus momentos e aos momentos da vida do Modernismo, impedindo que o curso destrutivo do rio, além de destruí-la, destrua também sua memória. E a memória dessa vida do espírito do poeta Mário de Andrade e do Modernismo é principalmente um ato de linguagem, compondo o poema com a mesma utilização da linguagem brasileira que foi a da sua obra toda. Coloquialismos, idiossincrasias, brasileirismos e expressões da cultura popular se fundem à solenidade dos versículos, como a vida do poeta se reverte às águas do rio. Desse modo, embora o assunto do poema seja o destino do poeta inserido no ritmo destrutivo da história brasileira, o seu acerto estético ainda é um momento construtivo, de verificação esclarecida da própria experiência, mesmo que seja em sua fase terminal.

Por um paradoxo imanente à configuração de "A Meditação sobre o Tietê", a luz que irradia do poema se deve à captação lírica de um processo de destruição. O poema faz de si mesmo uma destruição iluminadora do processo histórico de que fazem parte a obra poética de Mário e a sua atuação no Movimento Modernista. Uma destruição iluminadora, um tipo de expiação, que se opõe a outra destruição presente no poema, uma destruição predatória, cega e poderosa, que se apropria e acumula, e contagia de

\footnotetext{
${ }^{93}$ Procurei desenvolver esse "sentimento religioso da vida" no Capítulo IV desta tese.
} 
violência todas as coisas que toca. Essa violência de que se compõe o rio Tietê do poema, sendo também uma apreensão do processo histórico modernizador brasileiro, não é sentido somente como a força histórico-material de um processo político-social, mas como uma força mais poderosa do que os homens, impessoal e cega. Uma força mítica, primordial e indivisa, um mana. ${ }^{94}$ A história brasileira, principalmente a natureza de sua modernização, é captada no teor de sua violência, tão brutal que o poeta a formulou como uma regressão ao poder mais arcano e terrível que a humanidade experimentou, o poder do mana. Se no poema a história brasileira tem a configuração principalmente do mito, a que não faltam referências históricas, contudo, há na conferência "O Movimento Modernista" um processo destrutivo análogo, mas estrategicamente voltado contra a história política e social de então. Em 1942, ano dessa conferência de Mário, pronunciada no Itamaraty, o Estado Novo passava por seu momento de fastígio. Ele estava no auge do seu poder. O começo da virada antifascista da Segunda Guerra começaria apenas no ano seguinte, e só então prefiguraria o fim necessário do regime. E, como se sabe, a relação de Getúlio Vargas com o Modernismo nunca foi abertamente de adesão, mas sempre foi de acolhimento e vaga simpatia. ${ }^{95} \mathrm{~A}$ recíproca não é exatamente verdadeira, já que o grosso da intelectualidade modernista aderiu a Getúlio, e praticamente todos foram, direta ou indiretamente, por muito ou pouco tempo, funcionários de seu governo. A esse fenômeno se chamou de "cooptação" dos intelectuais, e essa é a tese do conhecido livro de Sérgio Miceli, Os intelectuais e a classe dirigente. ${ }^{96}$ Como um senso comum mal revisado, então, o Movimento Modernista convergiria, "cooptado", para a colaboração, construção ou justificação ideológica do nacionalismo de Getúlio Vargas e do Estado Novo. Tendo aparência de verdade, e sendo mesmo meia verdade, não se atentou para os problemas estéticoformais engendrados por essa configuração social nem para as tentativas de

\footnotetext{
${ }^{94}$ Sigo em relação ao "mana" a interpretação materialista desenvolvida por ADORNO, Theodor W.; HORKHEIMER, Max. Dialética do esclarecimento (Rio de Janeiro: Jorge Zahar, 1985), especificamente em Conceito de Esclarecimento, p. 28-31. José Antônio Pasta Jr., em sua tese de doutorado sobre Raul Pompéia desenvolve uma interpretação específica do "mana" na história brasileira, como será exposto no próximo tópico deste Capítulo, p. 11-17. Ver PASTA JR., José Antônio. Pompéia: a metafísica ruinosa d'O Ateneu. 1990. Tese (Doutorado em Literatura Brasileira) - Faculdade de Filosofia, Letras e Ciências Humanas da Universidade de São Paulo, 1990. p. 179 e 191-193.

${ }^{95}$ A simpatia e o apoio de Getúlio Vargas ao Modernismo datam de sua atuação como governador (cargo que então era denominado "presidente") do Rio Grande do Sul (1927-1929). Neste estado, ele apoiou (sem aderir) o Modernismo local, representado pelo grupo da Livraria do Globo, e "praticamente criou" a Revista do Globo, órgão desse Modernismo em seu momento final. Ver LEITE, Ligia Chiappini Moraes. Modernismo no Rio Grande do Sul. Materiais para o seu estudo. São Paulo: IEB, 1972. p. 251, 261, $357-$ 358.

${ }^{96}$ MICELI, Sérgio. Intelectuais e classe dirigente no Brasil (1922-1945). São Paulo: Difel, 1979.
} 
negatividade e oposição no seio do conformismo generalizado. A conferência de Mário aborda, desse modo, o tema da relação entre Modernismo e nacionalismo:

A radicação na terra, gritada em doutrinas e manifestos, não passava de um conformismo acomodatício. Menos que radicação, uma cantoria ensurdecedora, bastante acadêmica, que não raro tornou-se um porque-me-ufanismo larvar. [...] para um número vasto de modernistas, o Brasil se tornou uma dádiva do céu. Um céu bastante governamental... ${ }^{97}$

O Estado se apoderara do Modernismo, que, por sua vez, se acomodava prazerosamente no privilégio, operando a volta modernista da roda brasileira de modernizações conservadoras. Do ponto de vista de seu significado, a conferência de Mário de Andrade em um edifício governamental, comemorando os vinte anos da Semana de Arte Moderna, possuía, por assim dizer, toda uma simbologia conformista de comemoração cívico-estatal. O principal intelectual modernista, passadas duas décadas daquela explosão juvenil, faria - previsivelmente - um exame maduro, brilhante e mais ou menos convencional do Modernismo, apararia pela experiência de vida a irresponsabilidade de outrora e mostraria que o nacionalismo cívico de Getúlio suspendia e elevava aqueles ímpetos iniciais, que seriam a energia necessária para a construção nacional levada a cabo então. Essa, imagino, seria a versão conformista e pacificada do nosso Mário. Essa, possivelmente, a semiótica da conferência. No entanto, as conclusões do poeta são bem diferentes:

Não tenho a mínima reserva em afirmar que toda a minha obra representa uma dedicação feliz a problemas do meu tempo e minha terra. Ajudei coisas, maquinei coisas, fiz coisas, muita coisa! E no entanto me sobra agora a sentença de que fiz muito pouco, porque todos os meus feitos derivaram duma ilusão vasta. E eu que sempre me pensei, me senti mesmo, sadiamente banhado de amor humano, chego no declínio da vida à convicção de que faltou humanidade em mim. Meu aristocracismo me puniu. Minhas intenções me enganaram. ${ }^{98}$

E prossegue: "E si agora percorro a minha obra já numerosa e que representa uma vida trabalhada, não me vejo uma só vez pegar a máscara do tempo e esbofeteá-la como ela

\footnotetext{
97 ANDRADE, Mário de. O Movimento Modernista [1942]. Aspectos da literatura brasileira. Belo Horizonte: Itatiaia, 2002. p. 267. Sobre o livro de Miceli, será necessário notar que, sendo uma obra pioneira e, nesse sentido, um "clássico" das ciências sociais brasileiras, ele tem o defeito de ser cego, surdo e mudo em relação à dinâmica, às astúcias e às sutilezas da forma literária. Portanto, é preciso lê-lo com bastante cautela em estudos de crítica literária.

98 ANDRADE, Mário de. O Movimento Modernista [1942], cit., p. 277.
} 
merece. Quando muito lhe fiz umas caretas de longe. Mas isto, a mim, não me satisfaz". ${ }^{99}$ E conclui: "Eu não posso estar satisfeito de mim. O meu passado não é mais meu companheiro. Eu desconfio do meu passado". ${ }^{100}$ Não é estranho o "papa do Modernismo" passar a usar uma "rhétorique de Satan", ${ }^{101}$ para falar nos termos de Baudelaire? A maioria esmagadora das pessoas entendeu essa autocrítica destruidora como o resultado exagerado de um grave drama pessoal. Não se notou que, por maior que seja o peso biográfico-confessional dessas afirmações, elas operam uma astuta reconfiguração do significado e do sentido do Modernismo, tanto mais aguda e poderosa quanto o poeta se põe como alvo principal. Enfatizando ao longo de todo o texto que "o movimento modernista foi essencialmente destruidor", afirmando que "esse espírito destruidor" é "o seu sentido verdadeiramente específico", o que Mário faz nas afirmações sobre si e o Modernismo é revitalizar o potencial crítico do Modernismo. ${ }^{102}$ Ao demolir o edifício do Modernismo, da própria obra e de sua própria imagem, o que Mário faz é impedir que o Modernismo se consagre pela via conservadora e autoritária. Retomando do Modernismo seu potencial destruidor, Mário impede a apropriação do movimento pelo alto, às custas de si e do próprio movimento, bem entendido. Sem dúvida, Mário expõe e analisa as conquistas do movimento: "O direito permanente à pesquisa estética; a atualização da inteligência artística brasileira; e a estabilização de uma consciência criadora nacional"; ${ }^{103}$ porém, o sentido que essas conquistas adquirem em sua reflexão impede que elas se tornem uma linha de

\footnotetext{
${ }^{99}$ ANDRADE, Mário de. O Movimento Modernista [1942], cit., p. 277-278.

${ }^{100}$ ANDRADE, Mário de. O Movimento Modernista [1942], cit., p. 279.

${ }^{101}$ Chales Baudelaire. "Épigraphe pour un livre condamné", os versos da segunda estrofe são: "Si tu n'as fait ta rhétorique/Chez Satan, le rusé doyen,/Jette! Tu n'y comprendrais rien,/Ou tu me croirais hystérique".

102 ANDRADE, Mário de. O Movimento Modernista [1942], cit., p. 263. Que Mário conscientemente redefine o Modernismo pode ser comprovado pelo fato de, no momento imediatamente posterior à Semana, a revista Klaxon e Mário declararem o momento construtivo do Modernismo. Klaxon abre seu primeiro número com essas palavras: "A lucta começou de verdade em principios de 1921 pelas columnas do 'Jornal do Commercio' e do 'Correio Paulistano'. Primeiro resultado: 'Semana de Arte Moderna' especie de Conselho Internacional de Versalhes. Como este, a Semana teve sua razão de ser. Como elle: nem desastre, nem triumpho. Como elle: deu fructos verdes. Houve erros proclamados em voz alta. Pregaram-se ideias inadmissiveis. É preciso reflectir. É preciso esclarecer. É preciso construir. D'ahi, KLAXON" [grifo meu] (A REDACÇÃO. In: BRITO, Mário da Silva (Org.). KLAXON. mensário de Arte moderna. Edição fac-similar (1922-23). São Paulo: Livraria Martins, n. 1, p. 1, maio [de 1922] 1972). E Mário, em A escrava que não é Isaura (1922, Posfácio de 1924) fala em: "hoje, período construtivo". ANDRADE, Mário de. Obra imatura. Belo Horizonte: Itatiaia, 1980. p. 288. Há evidência de Mário de Andrade ser o autor do editorial de Klaxon, como defende a tese de CARVALHO, Lilian Escorel. A revista francesa L'Esprit Nouveau na formação das ideias estéticas de Mário de Andrade. 2 v. 2008. Tese (Doutorado em Literatura Brasileira) - Faculdade de Filosofia, Letras e Ciências Humanas da Universidade de São Paulo, São Paulo, 2008. p. 89.

103 ANDRADE, Mário de. O Movimento Modernista [1942], cit., p. 266.
} 
continuidade entre a modernidade do Modernismo e a modernidade do Estado Novo, pois a perspectiva destrutiva de Mário impede que essas conquistas sejam "carregadas no cortejo triunfal dos dominadores". 104

Em “O Movimento Modernista”, bem como em "A Meditação sobre o Tietê", as possibilidades de engajamento crítico do pensamento e da forma são o resultado da destruição, de um processo expiatório individual e coletivo. Mas esse resultado é fruto do choque de dois sentidos opostos da obra do poeta, presentes no poema e no texto: a "consciência da terra" levava ao mesmo tempo a avaliar o peso do passado brasileiro como resultado atual de uma história pregressa, e a possibilidade de superação desse passado a partir de um empenho civilizatório, de uma formação.

\section{Os Dois Rios ou Empenho Civilizatório e Mana Brasílico}

Uma imagem presente em livro muito apreciado por Mário de Andrade e outros modernistas, Rondônia, de Edgar Roquette-Pinto, define bem esses sentidos opostos da obra do poeta:

Quem atravessa Mato Grosso nota que seus arroios orientados para o Norte, contribuintes do Amazonas, e os que vão perder no Paraguai, nascem como irmãos gêmeos, lado a lado; entre uns e outros, não há montanhas. Dir-se-ia que se afastam, cada qual para seu destino, pela razão de uma vontade individual.

Quem bebe, pela manhã, águas que deveriam ir ter ao Atlântico meridional, à tarde pode matar a sede nas que são destinadas ao equatorial.

A comitiva almoça à beira de um regato filiado no rio da Prata, e pode sestear à margem de uma cabeceira da bacia do Amazonas. ${ }^{105}$

Na obra poética de Mário de Andrade, esses dois rios, como símbolos, são bastante reconhecíveis. O rio da história brasileira, do Brasil tal como está constituído, é o Tietê, rio da descoberta da terra. O rio do Brasil por fazer, do Brasil a civilizar, é o

\footnotetext{
104 "Todos os que até hoje venceram participam do cortejo triunfal, em que os dominadores de hoje espezinham os corpos dos que estão prostrados no chão. Os despojos são carregados no cortejo, como de praxe. Esses despojos são o que chamamos bens culturais" (BENJAMIN, Walter. Sobre o conceito de história. Magia e técnica, arte e política. Ensaios sobre literatura e história da cultura. São Paulo: Brasiliense, 1986. p. 225).

${ }^{105}$ ROQUETTE-PINTO, Edgar. Rondônia. São Paulo: Companhia Editora Nacional, 1975 [1 $1^{\text {a }}$ Edição de 1917]. p. 5.
} 
Amazonas, rio da criação da terra nova, que respeita o ritmo de sua própria natureza. ${ }^{106}$ Em “A Meditação sobre o Tietê", esse empenho civilizatório, cujo símbolo é o rio Amazonas, é analisado da perspectiva do fracasso, nos versos:

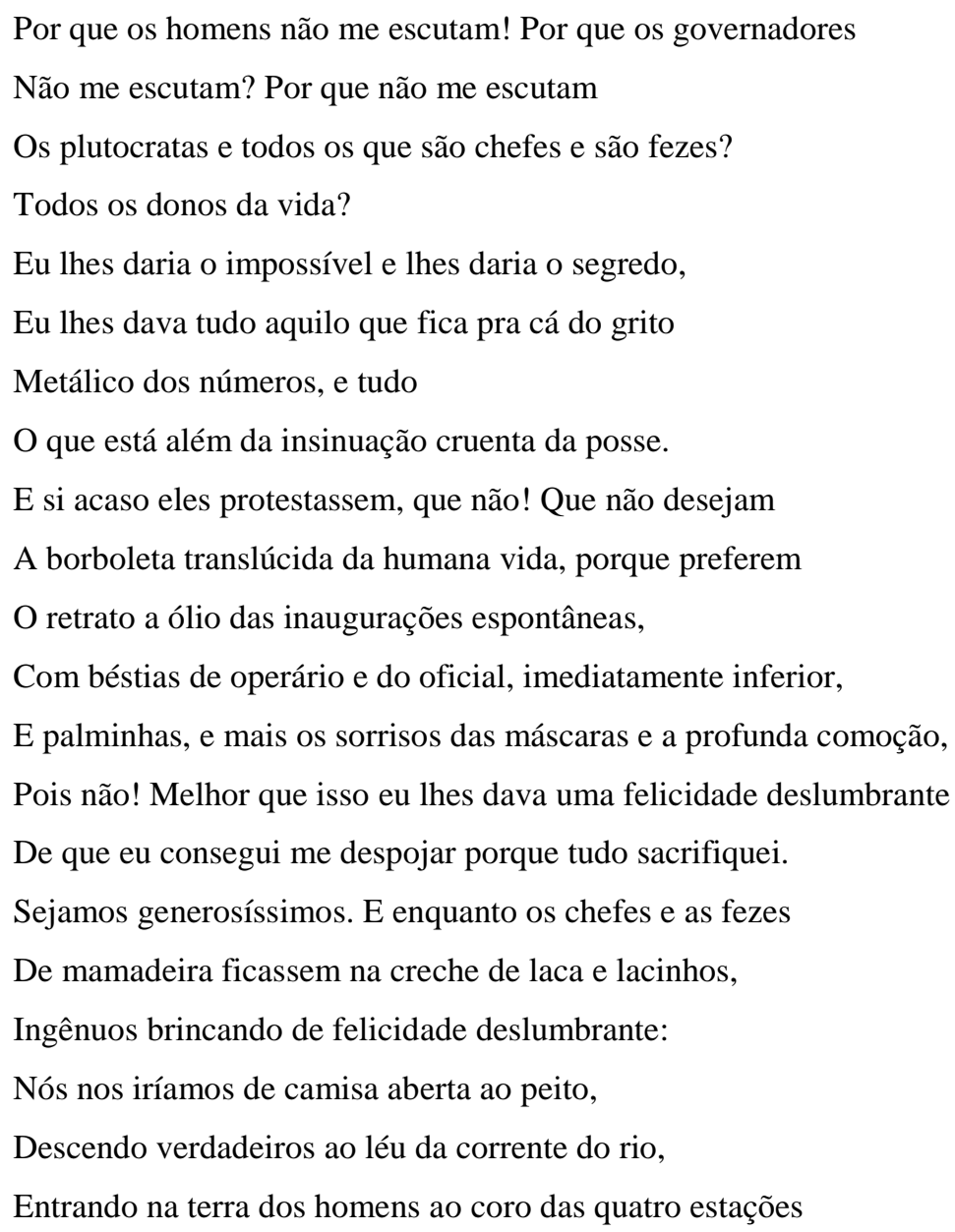

(versos 235-255)

Em seu momento terminal, o empenho construtivo da obra poética de Mário de Andrade adquire o aspecto de elegia irritada, pois sua demanda de futuro já se vê negada pelo desenrolar do presente, e sua perspectiva passa a ser a do futuro do pretérito. Nesse trecho, o poeta manifesta de modo mais evidente o que entendia por uma vida realizada e qual seria o seu papel na consecução desse ideal. O poeta deveria ser escutado, não como um oráculo, mas como um reservatório de vida autêntica, $o$ poeta seria a fonte da vida brasileira autêntica. No entanto, é necessário notar a natureza dessa fonte, pois se o poeta é a fonte da vida, ele não é o dono da vida e nem

106 Sobre a imagem e a simbologia desses rios na obra do poeta, ver KNOLL, Victor. Paciente arlequinada. Esboço de uma hermenêutica do imaginário na obra poética de Mário de Andrade (São Paulo: Hucitec, 1983), especificamente o Capítulo III - Dois Sinais e um Brasão. 
mesmo um oráculo que fornecesse novas tábuas da lei. Ele é uma fonte gratuita, não normativa e não autoritária. O que ela traz possui conotações mágico-míticas de um sacerdote-leigo: o impossível, o segredo, o que está para cá do dinheiro e para além da posse. Antes de desenvolver o processo pelo qual essa vida se realizaria, criando uma formação brasileira por uma via mágico-revolucionária filtrada pela própria energia vital do poeta, podemos notar o que se opõe a essa solução, que tipo de vida subjetiva e social prosperou e venceu o seu empenho civilizatório. O retrato dos "donos da vida" apresenta uma vida postiça, mostrada em sua faceta de pompa exterior: retrato a ólio, béstias (bestialógico ou discurso despropositado) de operário e oficial imediatamente inferior, palminhas, sorrisos de máscaras. Por aí notamos que se trata de uma pompa exterior e governamental. Mário configura a vida postiça nesse trecho como uma espécie de kitsch do poder, ostensivamente ridículo e, no entanto, profundamente destrutivo. Esse caráter a um tempo ridículo e destrutivo dos donos da vida é retomado nos versos seguintes como uma vida não só postiça como também infantil. A revolta do poeta contra esse tipo de vida pode ser lida na astuciosa construção dos versos 250 e 251, na ambiguidade do sintagma: "os chefes e as fezes de mamadeira ficassem...". A inversão da frase, com a anteposição da locução adverbial ao verbo, uma vez desfeita, ficaria: "os chefes e as fezes ficassem de mamadeira...", em que "fezes" substituiria o cortejo de subordinados do chefe. Contudo, "fezes de mamadeira" ressoa a locução adjetiva "mamadeira de fezes", fazendo o verso exalar o insulto indignado por essa vida, que Mário considera, em uma expressão grosseira, uma vida de merda. A essa falsa "felicidade deslumbrante", o poeta opõe a verdadeira, descrita na bela imagem: "a borboleta translúcida da humana vida”. Em que consiste essa humana vida? Como se chegaria a ela? O ideal descrito nos versos é de uma vida natural e acolhedora, vivida em comunhão com a terra, em alegria com a terra. Essa vida ativa e verdadeira, "de camisa aberta ao peito", não é uma retórica milagreira do poeta, embora seja alcançada pelo sortilégio, mas o resultado de um sacrifício. Mário escreve: “eu lhes dava uma felicidade deslumbrante/De que eu consegui me despojar porque tudo sacrifiquei" (versos 248-249). O poeta opera o “impossível”, “o segredo”, pelo sacrifício de si próprio. Ele agrega em seu corpo o corpo da nação, depura seus significados, sofre seus terrores, expurga a malignidade da terra e, renunciando à própria vida nesse processo, reelabora a nação, que se forma por meio do poeta. Ele opera em si o procedimento mítico atribuído pela tradição greco-latina ao deus Dionísio: o princípio morte- 
ressurreição, cuja origem de morte e reflorescimento da natureza é um dos mitos mais primários das organizações humanas. No trecho citado, o poeta apresenta o resultado: a felicidade deslumbrante é conseguida pelo seu sacrifício, mas nada sabemos do processo. Contudo, em momento posterior, lê-se uma forma mais desenvolvida desse procedimento mítico:

\footnotetext{
Por que os donos da vida não me escutam?

Eu só sei que não sei por mim! sabem por mim as fontes

Da água, e eu bailo de ignorâncias inventivas.

Meu baile é solto como a dor que range, meu

Baile é tão vário que possui mil sambas insonhados!

Eu converteria o humano crime num baile mais denso

Que estas ondas negras de água pesada e oliosa,

Porque os meus gestos e os meus ritmos nascem

Do incêndio puro do amor...
}

(versos 281-289)

Aqui comparecem em peso as atribuições de Dionísio: a dança (“o meu baile”), a música ("mil sambas insonhados"), o transe ("eu só sei que não sei por mim! sabem por mim as fontes"), o reflorescimento da terra arrasada ("eu converteria o humano crime em um baile mais denso...") e o ciclo morte-ressureição, em que os ritmos do poeta nascem do "incêndio puro do amor". A sofisticação da poesia de Mário de Andrade nesse trecho alcança um nível muito elevado, pelo padrão de entrelaçamento entre a cultura popular e a cultura erudita que ela estabelece. A solenidade do verso livreversículo e a profundidade de sua indignação e tristeza obedecem a um registro próximo do sublime, do modo de expressão dos profetas do Antigo Testamento. Mas essa solenidade é cadenciada por elementos da vida popular e do ritual primitivo, como o baile e o transe, o samba, as formas da língua falada. E, ainda, pela síntese de mito primitivo, cultura popular brasileira e religiosidade cristã que o poeta opera nesse trecho utilizando o procedimento de uma dança dramática. É o próprio Mário quem elucida a questão:

É curiosíssimo constatar que em grande número das nossas danças dramáticas se dá morte e ressurreição da entidade principal do bailado. No Bumba-meu-boi, nos Caboclinhos, nos Cordões de Bichos amazônicos, ainda nos Congos, nos Cucumbis e nos Reisados isso acontece. Se trata duma noção mística primitiva, encontrável nos ritos do culto vegetal e animal das 
estações do ano, e que culmina sublimemente espiritualizado na morte e ressurreição do Deus dos cristãos. ${ }^{107}$

Com uma dança dramática, então, Mário compõe poeticamente essa coreografia dionisíaca, realizando pela última vez "a constância coreográfico-dionisíaca que atravessa toda a minha poesia, e pra qual o Roger Bastide já chamou a atenção". ${ }^{108}$ Essa solução mítico-dionisíaca, entretanto, não projeta a "Meditação" para o "nada que é tudo" da mitografia. Ao contrário, ela é uma solução orientada para a matéria cultural, social e histórica nacional. É pelo apelo ao mito que Mário consegue recriar a humanidade brasileira conforme a potencialidade que se encontra incrustada e sufocada em sua própria realidade, de ser "verdadeiro", "camisa aberta ao peito". Trata-se de uma via poética para o problema da formação. Em O banquete, Mário aborda teoricamente o tema, quando o personagem Janjão do livro, músico de orientação libertária buscando patrocínio dos "donos da vida" da cidade de Mentira, em que transcorrem os diálogos do livro, reflete sobre sua obra e sua posição como artista. Diz o músico, ao argumentar sobre a função coletiva da arte, que, embora o Amor participe das manifestações da própria inteligência:

Eu não amo o povo, enquanto este é uma pessoa mais uma pessoa, mais uma pessoa. Estas pessoas só podem desagradar ao meu refinamento pessoal, ao meu aristocratismo. Nem quero ter comiseração delas, porque isto seria me aniquilar na balofa caridade esmoler dos cristãos [...]. Eu apenas exijo uma Justiça mais superior, que não consegue negar a fatalidade das classes enquanto classificação da validade individual dos homens em grupos coletivos [...] mas justiça a que repugna e suja a predeterminação classista, mantida pelas classes dominantes. ${ }^{109}$

Não estamos diante, como se vê, de um populismo paternalista ou de um catolicismo caritativo como ideias dirigentes de uma formação reacionária. Não é nesse tipo de formulação que seu "dionisismo" desemboca. Ao contrário, das insuficiências sociais

\footnotetext{
107 ANDRADE, Mário de. Danças dramáticas do Brasil. São Paulo: Livraria Martins, s/d. p. 23. [Redigido em 1934.]

${ }^{108}$ ANDRADE, Mário de. A Carlos Lacerda. In: PAES, José Paulo. Sobre "O Carro da Miséria". Revista do Instituto de Estudos Brasileiros, n. 36. São Paulo: IEB, 1994. É de importância fundamental distinguir o significado de Dionísio na obra de Mário de Andrade do significado a ele atribuído algumas décadas depois pelo Tropicalismo, principalmente por José Celso Martinez Correa. O "dionisismo" de Mário é uma solução para as impossibilidades da matéria histórica brasileira e nunca serviu de álibi para o valetudo ideológico, estético e sexual, como ocorre no "Tropicalismo antropofágico". Ver desenvolvimento do tema do dionisismo na nota 124.

${ }^{109}$ ANDRADE, Mário de. O banquete. Belo Horizonte: Itatiaia, 2004. p. 68. Segundo o ótimo prefácio de Jorge Coli e Luiz Carlos da Silva Dantas: "O que Janjão diz sai das profundezas da alma do autor" (COLI, Jorge; DANTAS, Luiz Carlos da Silva. Sobre O banquete, cit., p. 35).
} 
do artista, da sua incapacidade de conformação social, do artista pode, através de si e mesmo pela negação de si, criar uma nova humanidade:

Talvez seja horrível dizer: mas eu amo o povo porque ele é uma projeção de mim, amo ele enquanto ele faz parte apenas dessa humanidade que eu não sou, mas que exijo, porque só existo porque fiz ela existir. $\mathrm{O}$ artista é realmente o único profissional que cria a humanidade, e é condicionado pela sua criatura. Os conquistadores de povos, quer por meio da guerra quer por meio do capitalismo, não concebem a humanidade, nem eles! Porque são por natureza internacionais. Só o artista inventa a humanidade. Porque sendo out-law, extra-econômico por natureza, sem classe por natureza, sem povo por natureza, sem nação, o artista não deixa por menos: o que ele exige é a humanidade. [...] A minha consciência moral e intelectual exige de mim participar das lutas humanas. E eu participo. Solicito a verdade e pela síntese das obras de arte, proponho uma vida melhor e combato por. Eu, repudiando os nacionalismos, pela minha própria exigência de humanidade no entanto me esforço em ser nacional. ${ }^{110}$

Portanto, como essa citação deixa suficientemente explícito, quer criar uma nova humanidade, nacional em sua natureza de organização e modo de ser coletivos, mas participando da humanidade como um todo. Este é o sentido brasileiro do dionisismo de Mário de Andrade: recriar o Brasil, libertando suas potencialidades acolhedoras e amorosas, gerando uma sinergia dos homens com a terra. Nos termos simbólicos da poesia mariodeandradiana, pode-se afirmar que, quando o poeta escreve:

\footnotetext{
Nós iríamos de camisa aberta ao peito,

Descendo verdadeiros ao léu da corrente do rio,

Entrando na terra dos homens ao coro das quatro estações.
}

O impossível que ele está oferecendo pelo sacrifício dionisíaco é a transformação do rio Tietê no rio Amazonas, seu outro sinal, símbolo do Brasil possível, do homem formado em liberdade pelo ritmo da terra.

Mesmo em sua última expressão, ainda se observa a presença do empenho civilizatório, mas como uma promessa fracassada. A força que faz com que esse empenho fracasse não é composta apenas de "donos da vida" e "Demagogia". Eles são sujeitos ativos de uma força maior, eles como que atuam essa força maior, que está na natureza das próprias águas da história brasileira:

${ }^{110}$ ANDRADE, Mário de. O banquete, cit., p. 69. 
Vem de trás o estirão. É tão soluçante e tão longo,

E lá na curva do rio vêm outros estirões e mais outros,

E lá na frente são outros, todos soluçantes e presos

Por curvas que serão sempre apenas as curvas do rio.

Há de todos os assombros, de todas as purezas e martírios

Nesse rolo torvo das águas. Meu Deus! Meu

Rio! Como é possível a torpeza da enchente dos homens!

Quem pode compreender o escravo macho

E multimilenar que escorre e sofre, e mandado escorre

Entre injustiça e impiedade, estreitado

Nas margens e areias das praias sequiosas?

Elas bebem e bebem. Não se fartam, deixando com desespero

Que o resto do galé aquoso ultrapasse esse dia,

Pra ser represado e bebido pelas outras areias

Das praias adiante, que também dominam, aprisionam e mandam

A trágica sina do rolo das águas, e dirigem

O leito impassível da injustiça e da impiedade.

Ondas, a multidão, o rebanho, o rio, meu rio, um rio

Que sobe! Fervilha e sobre! E se adentra fatalizado, e em vez

De ir se alastrar arejado nas liberdades oceânicas,

Em vez se adentra pela terra escura e ávida dos homens,

Dando sangue e vida a beber. E a massa líquida

Da multidão onde tudo se esmigalha e se iguala,

Rola pesada e oliosa, e rola num rumor surdo

E rola mansa, amansada e imensa eterna, mas

No eterno imenso rígido canal da estulta dor.

(versos 209-234)

São dolorosos versos de espanto e indignação. Nesse trecho, nada oferece resistência ao curso do rio, e vemos sua natureza "pura", por assim dizer. A sua descrição é fundamentada em características mágico-míticas, a começar pela natureza de seu curso: do mar em direção à terra, "um rio que sobe!”. Além disso, ele carrega "a torpeza da enchente dos homens", é "leito impassível da injustiça e da impiedade", dá “sangue e vida a beber". Não há, contudo, personificação. O rio não é um monstro. O rio é uma poderosa força impessoal e mítica, com uma lógica terrível de destruição, que não se detém diante de nada. Um mana, de fato. Seguindo a definição de Adorno e Horkheimer, o mana é "primário, indiferenciado, ele é tudo o que é desconhecido, estranho: aquilo que transcende o âmbito da experiência, aquilo que nas coisas é mais 
do que sua realidade já conhecida". ${ }^{111}$ Mário percebe a natureza do curso das águas do Tietê como essa força mítica, um "espírito que move", ${ }^{112}$ acima mesmo dos "donos da vida", que passam a ser suas marionetes, impulsionando a história brasileira para sua finalidade destrutiva. Como algo de sobrenatural, o mana infunde nos homens o terror. ${ }^{113}$ Esse terror do indiferenciado marcou, segundo Adorno \& Horkheimer, o momento de uma humanidade subjugada pela natureza, uma humanidade frágil e inferior ao mundo em que habitava. $\mathrm{O}$ percurso do esclarecimento para vencer o terror primário e o mito (e sua recaída no mito) é todo o livro Dialética do esclarecimento, e não nos compete neste momento remontá-lo. O que é preciso enfatizar é a presença no poema de Mário do mana como algo que persiste e convive com a aspiração brasileira de modernidade (que pressupõe o esclarecimento). Quem atinou para o problema do mana na literatura brasileira foi José Antônio Pasta Jr., em seu estudo sobre $O$ Ateneu, de Pompéia. Em determinado momento de seu estudo, ao comparar o romance de Pompéia com Macunaíma, ele percebe a presença do indiferenciado como algo que impede os personagens desses romances de "aceder ao sentido", de saber o que eles são. Sem a intenção de me aprofundar no argumento de seu estudo, quero chamar a atenção para um comentário em que o indiferenciado, o mana, é identificado à barbárie brasileira. Observando a tristeza enorme do final do romance Macunaíma, com a essencialização do personagem no "brilho inútil das estrelas", Pasta Jr. se pergunta: "Quanto do que constitui o cerne horrível da barbárie brasileira - feito de brutalidade e extermínio - não se refrata aí?". ${ }^{114}$ Com a diferença de que nos versos em questão não se trata mais de "refração", pois "A Meditação sobre o Tietê" está propriamente imersa na barbárie brasileira, e o poema formaliza o choque: o poder do mana exercendo seu terror sobre a fragilidade do indivíduo. Seguindo a trilha da "barbárie brasileira", Pasta Jr. dá especificação brasileira ao terror mítico, a que chama "mana brasílico". ${ }^{115} \mathrm{O}$ autor vai desenvolvê-lo como presença do sobrenatural terrível, "mistério enigmático ou enigma misterioso", como impossibilidade de autoconstituição, impossibilidade de identificação do sujeito consigo mesmo, dada a conjunção da demanda moderna de

\footnotetext{
111 ADORNO, Theodor W.; HORKHEIMER, Max. Dialética do esclarecimento. Rio de Janeiro: Jorge Zahar, 1985. p. 28-29. "O mundo totalmente dominado pelo mana, bem como o mundo do mito indiano e grego, são, ao mesmo tempo, sem saída e eternamente iguais” (ADORNO, Theodor W.; HORKHEIMER, Max. Dialética do esclarecimento, cit., p. 30).

${ }^{112}$ ADORNO, Theodor W.; HORKHEIMER, Max. Dialética do esclarecimento, cit., p. 29.

113 "O grito de terror com que é vivido o insólito [o sobrenatural, o mana] torna-se o seu nome" (ADORNO, Theodor W.; HORKHEIMER, Max. Dialética do esclarecimento, cit., p. 29).

${ }^{114}$ PASTA JR., José Antônio. Pompéia, cit., p. 149.

115 PASTA JR., José Antônio. Pompéia, cit., p. 179.
} 
subjetivação e a simultânea anulação dessa demanda pelas práticas do escravismo e do favor. Estamos em face de uma presença simultânea de duas rotações antagônicas: a do tempo histórico, que é progressivo e em que os fenômenos adquirem significação substantiva; e a da eternidade a-histórica, da repetição eterna do mesmo (tão conhecida dos brasileiros) em que as coisas são sempre as mesmas em formato diferente, gerando não uma significação substantiva, mas uma perenidade fantasmagórica. A simultaneidade dessas rotações faz com que o tempo moderno da história e o tempo ahistórico do mito convivam e se confundam, passando frequentemente um no outro. A inexistência de fronteira entre o tempo da história e o tempo do mito elimina igualmente as fronteiras entre sujeito e alteridade, entre sujeito e objeto, entre o mesmo e o outro, o que dá origem a um mundo composto de objetos e sujeitos sempiternamente metamórficos, de significação intangível. O que muda, então, na comparação do mana europeu da Dialética do esclarecimento e o "mana brasílico" de Pasta Jr. é que no mundo abordado por Adorno e Horkheimer estabelece-se o controle e a superação do mana pelo esclarecimento, ${ }^{116}$ já no "mundo brasileiro", o mana não é controlado pelo esclarecimento mas, ao contrário, eles convivem e se confundem, pervertendo na origem o estatuto civilizador do esclarecimento e redobrando o poder destrutivo do mana, que opera incontido, como as águas do Tietê no poema de Mário. ${ }^{117} \mathrm{Em}$ "A Meditação sobre o Tietê", o mana vai sendo descoberto na medida em que as águas do rio se desenrolam, ele é desenvolvido na proporção do terror que causa, e o poeta tenta, à sua maneira, exorcizá-lo pela sua enunciação. O mana da "Meditação" é a infiltração da realidade brasileira na vida e na obra do poeta, e o poema - ao contrário das águas do Tietê - é suficientemente cristalino para deixar evidente essa infusão do mana. ${ }^{118} \mathrm{O}$ poeta capta agindo em si o princípio destrutivo do mana. Em desespero, Mário confia ainda na enunciação do terror como modo de apaziguá-lo. Mas essa tentativa de

\footnotetext{
${ }^{116}$ A transformação do próprio esclarecimento em mito é o tema do livro de Adorno e Horkheimer e foge ao intuito da minha exposição no momento. É necessário dizer, no entanto, que, embora problemático desde a origem, o esclarecimento europeu é um elemento de distinção e estabelecimento de fronteiras, adquirindo um estatuto normativo e necessário, mesmo quando criticado ou antagonizado. A ausência de esclarecimento, como estamos vendo, é menos uma festa de confraternizações e conciliações - como querem certas teorias apologéticas da via brasileira - do que o mundo dos estados-limite, violentos e destrutivos, pertencentes à esfera do indistinto, do mana.

${ }^{117}$ Para maior desenvolvimento do assunto, abordando o romance de Raul Pompéia e a obra de Machado de Assis, ver PASTA JR., José Antônio. Pompéia, cit. Como complemento sobre a simultaneidade do tempo histórico e do tempo a-histórico, lê-se com proveito: PASTA JR., José Antônio; PENJON, Jacqueline. Le rythme singulier d'une formation historique. In PASTA JR., José Antônio; PENJON, Jacqueline (Org.). Littérature et modernisation au Brésil. Paris: Presses Sorbonne Nouvelle, 2004.

118 Tão evidente que a fortuna crítica de Mário nem se preocupou em abordá-lo... É notório o quanto a "barbárie brasileira" e suas consequências estão ausentes da crítica de poesia brasileira.
} 
apaziguamento do mana custa sua obra poética toda e sua energia vital, que o rio também prende e leva no seu "leito impassível de injustiça e impiedade". O aprofundamento de Mário na matéria brasileira não deixa de mostrar aqui um ponto de fraqueza: identificado à matéria brasileira, o poeta e sua obra são vítimas da natureza dessa matéria. O esforço de brasilidade tem desfecho trágico, o poeta é vítima do próprio empenho. Mas fragilidade e força derivam de um mesmo princípio, e o poeta formula poeticamente as consequências do empenho civilizatório e torna visível o "mana brasílico", que até então mal se vislumbrava em sua poesia e na poesia modernista.

Contudo, Mário reorganiza todas as forças para tentar conter e suportar o rio da história brasileira, o rio Tietê e seu mana. Vimos no começo deste Capítulo como toda a sua obra converge para o poema. Tal reagrupamento da obra não é gratuito, faz parte de um fio pouco visível, e no entanto constante, no poema: o empenho civilizatório tentando resistir ao poder do mana, a presença simultânea em "A Meditação sobre o Tietê" do rio Tietê e do rio Amazonas, como se eles corressem dentro do poema, em sentido contrário, ao mesmo tempo, e sobrepostos.

\section{Os Rios Sobrepostos}

Mário dá um passo além daquela imagem do livro de Roquette-Pinto, e pode-se observar em “A Meditação sobre o Tietê" não apenas os rios do empenho civilizatório e do "mana brasílico" correndo em direções opostas mas também correndo sobrepostos. ${ }^{119}$ Inicialmente, essa "sobreposição" pode ser acompanhada por meio de algumas referências na obra e na correspondência de Mário de Andrade em que, de certa forma, o rio Amazonas, o "outro sinal" do poeta, ronda a composição de "A Meditação sobre o Tietê”. Em final de 1943, Mário revê o livro O turista aprendiz para a publicação, contendo suas viagens para o Amazonas e para o Nordeste. Há especificamente um "Prefácio" para a viagem amazônica, em que expõe seu desgosto pelo "personalismo" do livro, já na perspectiva crítica dos últimos anos de Mário. No relato desse livro, partindo do Rio de Janeiro, o poeta anota: "A água geme oleosa, pesadíssima, refletindo devagar a iluminação assanhada das praias", ${ }^{120}$ que lembra o

\footnotetext{
${ }^{119}$ Logicamente, trata-se de uma imagem literária, de uma produção simbólica mágico-mítica, capaz de subverter a ordem geográfica e a característica de seus fenômenos.

${ }^{120}$ ANDRADE, Mário de. O turista aprendiz. Belo Horizonte: Itatiaia, 2002. p. 54.
} 
começo da "Meditação". Ainda sobre essa viagem ao Amazonas, Mário fala em carta a Drummond, de 12 de agosto de 1944, de um "lindíssimo poema da 'Meditação sobre o Amazonas', cuja ideia primeira veio dessa viagem. Seria assim como um coroamento de um dos meus caminhos, como o 'Noturno de Belo Horizonte', como a 'Louvação da Tarde', como os 'Poemas da Amiga' são também fins de caminhos. Mas nunca saiu... Abandonei" [grifo do original]. ${ }^{121}$ Também em carta a Drummond, de 15 de outubro de 1944, Mário escreve: "me bateu um bruto desejo de fazer uma poesia, uma espécie de 'Meditação sobre o Tietê' que ando premeditando pra Lira [paulistana] e que não tem nada que ver com uma ambiciosa 'Meditação sobre o Amazonas' que muito tempo andei desejando escrever, nunca saiu". ${ }^{122}$ E o poema "A Meditação sobre o Tietê" data de 30 de novembro de 1944 - 12 de fevereiro de $1945 .{ }^{123}$ Não se trata, como se vê pela última citação, da mudança de título de um mesmo poema ou mesmo de familiaridade entre as duas concepções. Antes, penso em certa familiaridade intuitiva entre a presença do Amazonas e a presença do Tietê, a presença simultânea de ambos no imaginário poético de Mário. O Amazonas está fora da concepção de "A Meditação sobre o Tietê", mas está presente no espírito do poeta, como seu "outro sinal", rondando sua poética, como a estrela da civilização brasileira possível. No poema, em minha hipótese, o rio Amazonas, como o rio purificador, é oposto ao rio Tietê. É ele que produz a resistência do eu lírico, sua capacidade de perceber a enunciar a natureza do rio do contágio, o Tietê. A resistência do rio purificador é progressivamente tomada pelo rio do contágio, até condensar-se em uma "alga escusa", ao fim do poema. Porém, a dignidade da revolta do poema depende dessa força contrária ao rio Tietê, e é ela que confere dramatismo ao poema. A presença desse outro rio sendo progressivamente vencido pode ser visto ao longo do poema:

Eu me reverto às tuas águas espessas de infâmias,

Oliosas, eu, voluntariamente, sofregamente, sujado

De infâmias, egoísmos e traições. E minhas vozes,

\footnotetext{
${ }^{121}$ SANTIAGO, Silviano (Org.). Carlos \& Mário. Correspondência de Carlos Drummond de Andrade e Mário de Andrade. Rio de Janeiro: Bem-Te-Vi, 2002. p. 526.

${ }^{122}$ SANTIAGO, Silviano (Org.). Carlos \& Mário. Correspondência de Carlos Drummond de Andrade e Mário de Andrade, cit., p. 532.

${ }^{123}$ ANDRADE, Mário de. Poesias completas. Edição crítica de Diléa Zanotto Manfio. Belo Horizonte: Itatiaia; São Paulo: Edusp, 1987. p. 497. Mário morreu 13 dias depois de terminar o poema.
} 
Perdidas do seu tenor, rosnam pesadas e oliosas,

Varando terra adentro no espanto dos mil futuros,

À espera angustiada do ponto.

(versos 49-54)

Alguma coisa, nesse "eu" (verso 49), se quebra e se dispersa sob a força do rio Tietê, alguma coisa foi "sujada", e o que foi rompido "rosna" tomado de imundície, olhando de longe os "mil futuros" que se afastam, se interrogando como acaba esse espetáculo horrendo. A capacidade de sentir o baque das águas espessas de infâmia, de dar nome à sua sujeira é o que eu chamo de um rio purificador que se opõe ao rio do contágio. Sem essa reserva de águas purificadoras que vão sendo sujadas, não haveria no poema critério de distinção, seria uma noite líquida e uma água noturna sem uma luz que desse a dimensão de sua escureza. Por isso o poeta portador de águas puras se sente sujado e os fragmentos dispersos das águas puras ainda rosnam sob o óleo contagioso e se espantam dos "mil futuros" antes de se fundirem definitivamente ao rio do contágio.

Em outra passagem, há maior subjetivação desse processo:

Isto não são águas que se beba, conhecido! Estas águas

São malditas e dão morte, eu descobri! E é por isso

Que elas se afastam dos oceanos e induzem à terra dos homens,

Paspalhonas. Isto não são águas que se beba, eu descobri!

E o meu peito das águas se esborrifa, ventarrão vem, se encapela,

Engruvinhado de dor que não se suporta mais.

Me sinto o pai Tietê! ôh força dos meus sovacos!

Cio de amor que me impede, que destrói e fecunda!

Nordeste de impaciente amor sem metáforas,

Que se horroriza e enraivece de sentir-se

Demagogicamente tão sozinho! Oh força!

Incêndio de amor estrondante, enchente magnânima que me inunda,

Me alarma e me destroça, inerme por sentir-me

Demagogicamente tão só!

(versos 78-91)

A referência ao "pai Tietê" é menos uma identificação do eu lírico com o rio do que com o "espírito do rio", entidade indígena das forças da natureza. A entidade mítica também é vitimada, faz parte do mesmo complexo purificador do rio Amazonas, do ritmo natural da terra brasileira. O pai Tietê é diferente do rio Tietê, é mesmo 
antagônico a ele. Em versos posteriores aos citados, também o pai Tietê é hostilizado pelas águas do contágio, e ele "se vai num suspiro educado e sereno,/Porque és demagogia e tudo é demagogia" (versos 130-131). O poeta se identifica com esse espírito do rio: "Me sinto o pai Tietê", e é nessa dimensão de portador de forças míticas e purificadoras que opõe no poema o rio purificador ao rio do contágio. A natureza oposta do sujeito lírico e do rio ocorre no modo como o sujeito lírico sente a invasão das águas: elas invadem o peito do poeta em uma ascensão brutal de força, pois elas primeiro esborrifam, depois vêm em ondas com um "ventarrão", e o sujeito lírico, tomado pela águas, se torna agitado, encrespado (“encapela"), fica "engruvinhado de dor que não se suporta mais”. Esse choque de forças que contém traços marcadamente míticos e telúricos é que sustenta, a meu ver, a hipótese de dois rios sobrepostos em antagonismo. A presença implícita das águas do rio purificador tem a função de mapear o rio do mana, de torná-lo conhecido por meio da demonstração de como age a sua força destrutiva. $\mathrm{O}$ rio purificador age como uma matéria cristalina que, ao ser lentamente destruída, revela a natureza daquilo que a destrói. Mas a função das águas purificadoras tem ainda outra configuração, que deriva da mesma resistência purificadora às águas destrutivas. A destruição das águas purificadoras pelas águas do contágio traz progressivamente a proximidade da destruição final, da morte, e, na vizinhança da morte, o poeta inicia uma dicção febril, pois os versos adquirem sentidos antagônicos e contraditórios. O poeta, munido de forças míticas, se sente “demagogicamente tão sozinho", e se não bastasse essa alternância de sujeito mítico (pai Tietê) e sujeito frágil (demagogicamente tão só), as próprias águas começam a ganhar significados ambivalentes e antagônicos: elas se tornam um "incêndio de amor", transmutando o elemento em que o sujeito lírico está, pois ele incendeia-se com água e, ainda, as águas infectas que o tomam pelo "ventarrão" se chocam com uma enchente contrária, purificadora mas imaginária, "magnânima", que inunda o poeta. Esses versos difíceis mimetizam um verdadeiro transe, uma disposição eufórica e febril que antecede um momento sacrificial. Nos versos finais do trecho citado, o poeta está só, destroçado e alarmado. Essas palavras são ainda expressão do transe, pela própria simultaneidade de sensações que transmitem: a solidão e o despedaçamento, a perda da lucidez e a disposição alerta. Como numa febre, o sujeito lírico está ao mesmo tempo muito frio e fervendo. É preciso, então, indagar sobre a natureza simbólica desse choque entre as águas purificadoras e as do contágio, principalmente sobre as consequências no interior 
da subjetividade lírica da vitória das águas do contágio sobre as da purificação. O sujeito lírico é literalmente destroçado pelas águas, mas o que subjaz a isso é a pergunta: o que se está destroçando? A resposta está repetida nos versos: o amor, um cio de amor, um Nordeste de amor, um incêndio de amor. O amor que é incêndio, que "destrói e fecunda", expõe a questão principal, a maior de todas da obra poética de Mário: o dionisismo e, em relação a ele, o sacrifício. É pelo dionisismo que o poeta pode fazer da sua própria destruição uma promessa libertadora. Como Dionísio, o sujeito lírico ativa o ciclo morte-ressurreição de que o sacrifício faz parte; desse modo, a sobreposição dos rios e o choque das águas, em que as águas do contágio destroem as da purificação, guardam o sentido dionisíaco do sacrifício: pela destruição das águas purificadoras, bem como pela aniquilação do sujeito lírico, eles - as águas purificadoras e o sujeito lírico retornarão mais fortes. Essa constelação mítico-simbólica desponta na poesia de Mário sempre que esta, em sua busca de dar forma à experiência brasileira, se defronta com a impossibilidade. ${ }^{124}$ Por ser mais fraco do que as águas do mana brasílico e se sentir vencido pelo ritmo destrutivo da história brasileira, Mário de Andrade busca direcionar a morte simbólica de sua obra em um sentido libertador, a expensas do mito e de si mesmo, que se aniquila imerso no mito. Por isso o encontro das águas sobrepostas pode ganhar, no interior do sujeito lírico, um movimento metamórfico e incendiá-lo de amor. Porém, nesse trecho citado da "Meditação", esse amor também é levado de vencida nas águas do rio, e o sentimento de um sentido que se perde volta mais explícito em outra passagem:

\footnotetext{
${ }^{124}$ ANDRADE, Mário de. A Carlos Lacerda. In: PAES, José Paulo. Sobre "O Carro da Miséria”, cit., p. 181-182. Mário escreve "é a constância coreográfico-dionisíaca que atravessa toda a minha poesia, e pra qual o Roger Bastide já chamou a atenção. Em quase todos os grandes momentos extasiantes, na dor ou na alegria, eu 'me dissolvo em dança"'; contudo, no texto de Bastide sobre a poesia de Mário, a passagem a que o poeta se refere é um pouco diferente: “... na vida sentimental de Mário de Andrade, tanto seus momentos dionisíacos como seus momentos tenebrosos, se tornam samba, coco, inventam novos passos, e sua obra nos toma pelos músculos, pelas vísceras, para impor seu ritmo a nosso ser, para nos transformar, por sua vez, em ballet brasileiro" (BASTIDE, Roger. Mário de Andrade [1940]. Poetas do Brasil. São Paulo: Edusp/Duas Cidades, 1997). A preeminência que Mário dá à expressão "coreográficodionisíaca", que não se encontra no texto de Bastide, revela o modo como o próprio poeta sentia sua poesia. O tema do "dionisismo" em Mário é pouco estudado e uma abordagem interessante sobre esse tema na obra Café está em CARVALHO, Sérgio de. O drama impossível. O teatro modernista de Antônio de Alcântara Machado, Oswald de Andrade e Mário de Andrade. 2002. Tese (Doutorado em Literatura Brasileira) - Faculdade de Filosofia, Letras e Ciências Humanas da Universidade de São Paulo, São Paulo, 2002. p. 178-183.
} 
Angúrios mornos afogam

As altas torres do meu exausto coração.

Me sinto esvair no apagado murmulho das águas.

Meu pensamento quer pensar, flor, meu peito

Quereria sofrer, talvez (sem metáfora) uma dor irritada...

Mas tudo se desfaz num choro de agonia

Plácida. Não tem mais formas nessa noite, e o rio

Recolhe mais esta luz, vibra, reflete, se aclara, refulge,

E me larga desarmado nos transes da enorme cidade.

(versos 177-185)

A perda de forças, a invasão das águas do contágio nas águas da purificação chega a um ponto de anestesia, em que nem mais a dor irrita, e as águas da energia vital, purificadoras, são reduzidas a um "choro de agonia plácida", de uma agonia já esfriada. Pelo desaparecimento progressivo dessas águas, o poema perde seu poder de iluminação e distinção ("não tem mais formas nessa noite"), e o Tietê "recolhe mais esta luz", vence mais uma etapa da eliminação da resistência, deixando o eu lírico na vizinhança da morte, no transe, na incapacidade de sentir, de se revoltar. Entretanto, é ainda o último reflexo das águas purificadoras chorando que ilumina essa passagem e torna mais essa derrota uma agonia visível. E, mais adiante, acelerado o ritmo do poema em um transe, como um tipo de postergação de uma morte definitiva, há o ciclo dionisíaco que encerra a "Meditação". Da vizinhança da morte em que o poema deixa o sujeito lírico, segue um transe de indignação e começa o dionisismo quando o poeta diz: "Pois que mais uma vez eu me aniquilo sem reserva" (v. 256). E um delírio de amor se segue, uma ebulição poética quando a última reserva das águas purificadoras está acabando. Seguem-se os versos já citados: ${ }^{125}$

Eu só sei que eu não sei por mim! sabem por mim as fontes

Da água, e eu bailo de ignorâncias inventivas.

Meu baile é solto como a dor que range, meu

Baile é tão vário que possui mil sambas insonhados!

Eu converteria o humano crime num baile mais denso

${ }^{125}$ Ver p. 56. 
Que estas ondas negras de água pesada e oliosa,

Porque os meus gestos e os meus ritmos nascem

Do incêndio puro do amor...

(versos 282-289)

Em outro grande paradoxo poético, as "fontes da água" e o "incêndio puro do amor" estão unidos na origem do sentimento lírico. Aqui temos, como vimos, um baile em transe, uma ebulição delirante, cuja intenção é transpor pelo ciclo morte-ressurreição a possibilidade de uma purificação para além dela, pois já pouco sobra para se opor às águas do contágio. E, por fim, nada mais haverá para opor-se ao mana:

Eu recuso a paciência, o boi morreu, eu recuso a esperança.

Eu me acho tão cansado em meu furor.

As águas apenas murmuram hostis, água vil mas turrona paulista

Que sobe e se espraia, levando as auroras represadas

Para o peito do sofrimento dos homens.

... e tudo é noite. Sob o arco admirável

Da Ponte das Bandeiras, morta, fraca,

Uma lágrima apenas, uma lágrima,

Eu sigo alga escusa nas águas do meu Tietê.

(versos 322-330)

O ciclo dionisíaco não se completa, não há sacrifício, mas aniquilação. Das águas purificadoras, entretanto, fica um pouco, "uma lágrima", uma "alga escusa". Assim como as "auroras represadas" - uma imagem muito bela - vão para o peito dos homens, o rio também leva para o futuro um tipo de "dionisismo represado", uma lágrima que é também uma fagulha, como a fonte das águas também é um incêndio de amor, e cuja promessa é uma destruição mais completa de tudo, um possível retorno de um Amazonas mais forte, capaz de incendiar o Tietê. E mesmo a alga escusa, que é o corpo morto do poeta, traria latente o renascimento de um Brasil purificado. Pela própria natureza sacrificial do ciclo morte-ressurreição do dionisismo, o poema precisa, para guardar essa lágrima-fagulha, levar a cabo a destruição total do poeta e sua obra. Tanto o eu lírico mariodeandradiano quanto sua obra poética trazem a convivência da história brasileira sedimentada - as águas do contágio do Tietê -, e o impulso de construção do Brasil novo, pela estética moderna, pela liberdade de temas e ritmos, pela aceitação e autodeterminação de si mesmo - as águas purificadoras do Amazonas -, que 
simbolizam, a posteriori, uma determinação histórico-estética de sua poesia, mesmo antes de ser assumida como símbolo explícito na obra do poeta. Sua obra contém, então, em germe, o conflito fundamental que explode em "A Meditação sobre o Tietê". Mais ainda, em sua obra e em si mesmo, Mário reconhece a presença, voluntária ou involuntária, do Brasil sedimentado, das águas do contágio, e conclui que eles, obra e poeta, também já fazem parte da história brasileira, já estão contaminados. A expiação completa da história brasileira, a contenção do "mana brasílico", o retorno vitorioso do empenho civilizatório já não podem poupar essa poesia e esse sujeito lírico. O passado do poeta já não é mais seu companheiro. Essa promessa de salvação pela expiação completa era sentida pelo próprio Mário enquanto fazia o poema, como diz em carta a Drummond:

Ando fazendo um poema chato, pesado, difícil de ler, longo demais, duro nos ritmos, cadencial, bárdico, uma espécie de "Meditação sobre o Tietê". É o que me dá alento, que o resto, trabalho, vida, ver os outros daqui, os da elite da esquerda politicando, carcomidos aos vinte anos tanto como um perrepista sexagenário, a intriga, o meu cartaz, tudo me dá desalento. Só o poema me salva e acredito nele, amo ele, me umedece os olhos. E cada palavra que consigo acertar naquela dureza cadencial que não é verso livre mais, parece que achei a virgem, dá pra aguentar dois dias mais sem estouro [grifo meu]. ${ }^{126}$

A solução da poesia de Mário para a matéria histórica brasileira, tal como ela se configurava em 1944, após todo o ciclo do Modernismo e da primeira modernização maciça da sociedade brasileira, era uma expiação completa. Uma solução míticodionisíaca, que, ao longo de sua obra, monta todo um complexo dionisíaco-sacrificial, e que em seu último momento tem sua formulação mais radical. O complexo dionisíacosacrificial é uma solução mítica, mas é também, como vimos, uma hermenêutica histórica e, no limite, uma estranha práxis histórico-mítica. A destruição dionisíaca que se dá no plano do mito acaba por ser também uma negação específica, em poesia modernista e linguagem poética bem brasileira, de toda a história brasileira, uma espécie de "Delenda Brasilia", ${ }^{127}$ que não deixa de ser um engajamento radical da forma poética

\footnotetext{
${ }^{126}$ SANTIAGO, Silviano. (Org.). Carlos \& Mário. Correspondência de Carlos Drummond de Andrade e Mário de Andrade, cit., p. 539.

127 "O Brasil deve ser destruído", paráfrase que imaginei a partir do "Delenda Carthago", de Cícero. Sobre o sentimento de Mário em relação ao Brasil na década de 1940, é de particular interesse esse trecho de carta a Álvaro Lins de 4 de julho de 1942: "Pra esses moços [da década de 1940], como pra os modernistas da minha geração o Macunaíma é 'a projeção lírica do sentimento brasileiro, é a alma do
} 
no plano da história, pois, destruindo o Brasil sedimentado, abre-se a senda de um Brasil novo, que se recriaria histórica e miticamente com as suas próprias forças, em diálogo franco e não subordinado com o mundo. Mas essa promessa, como sabemos, ainda está presa e cifrada no plano do mito, vagando como alga escusa pelas águas do Tietê.

Brasil virgem e desconhecida', que virgem nada! que desconhecida nada! Virgem, meu Deus! será muito mais um cão de nazista!" (ANDRADE, Mário de. Cartas de Mário de Andrade a Álvaro Lins. Rio de Janeiro: José Olympio, 1983. p. 66). 


\section{CAPÍTULO II - VERDADE PSICOLÓGICA OU OS LIMITES DO SUJEITO LÍRICO}

Sou tudo o que vocês quiserem,

Mas que sou eu?

Mário de Andrade. "Danças"

A solução mítico-dionisíaca surge na poesia de Mário de Andrade em seus momentos extremos, quando o poeta, em confronto com a matéria histórico-social, precisa solucionar o que é insolúvel. Como expressão de um extremo, ela é um tour de force, ${ }^{128}$ um prodígio sobre-humano, que resulta do fim de um processo a que falta finalidade. Em outras palavras, o sentido originário da obra poética de Mário não era o da imersão no mito; ao contrário, sua intenção era contribuir para a construção e a consolidação de uma literatura moderna e nacional, como elemento fundamental de uma cultura nacional, base de uma emancipação social brasileira. ${ }^{129}$ É nesse sentido que ela procede à aclimatação de formas modernistas e, ao mesmo tempo, a uma hermenêutica da matéria histórico-social brasileira. Hermenêutica esta que se dá, consecutivamente, no âmbito da modernidade da cidade, dos modos da linguagem falada, do folclore e da disparidade geográfica, das consequências sociais e subjetivas da modernização brasileira. Do ponto de vista da subjetividade lírica, que é o tema deste capítulo, esse processo de criação de uma poesia modernista e moderna brasileira assume formas

\footnotetext{
${ }^{128}$ Sobre o tour de force, ver ADORNO, Theodor W. Teoria Estética. Lisboa: Edições 70, 2008. p. 165167. "As obras que são planeadas como tour de force, como acto equilibrista, revelam algo de superior a toda a arte: a realização do impossível" (p. 165). Adorno está pensando na lógica e na integridade da grande obra de arte em um mundo danificado e fragmentário. Para o contexto brasileiro, o tour de force tem uma função específica: conciliar o que é inconciliável. Sobre o tour de force brasileiro, há essa passagem iluminadora de Roberto Schwarz, quando, acompanhando a narrativa machadiana de Dom Casmurro, se pergunta: "Como conciliar a dependência, que era inevitável, com a autonomia, que era de rigor? Ou ainda, como ser moderno e civilizado dentro das condições geradas pelo escravismo?" e conclui: "Veremos que as soluções imaginárias para essa verdadeira quadratura do círculo são especialidades do sentimento-de-si nacional e da ficção machadiana" (Duas meninas. São Paulo: Companhia das Letras, 1999. p. 19). E José Antônio Pasta Jr., em texto sobre Macunaíma, desdobra o significado do tour de force para o romance e para o significado geral da obra de Mário: "É a lógica dessa ultrapassagem que não supera [modernizar os circuitos mercantis mantendo intactas as relações políticas e sociais arcaicas] - impulso de transformação que elude justamente o momento da mediação - que o Macunaíma isola e espectraliza, promovendo-a a princípio formal da obra. Macunaíma - e, de certo modo, também seu Autor - é esse tour de force, por assim dizer, encarnado, o que lhe imprime a referida qualidade dramática que só a assunção dos conflitos mais desatados, por uma entidade individual, pode manifestar" (PASTA JR., José Antônio. Tristes estrelas da Ursa. Macunaíma. In: AVANCINI, José Augusto; SILVA, Márcia Ivana de Lima e (Org.). Cadernos ponto \& vírgula, n. 4. Porto Alegre: Secretaria Municipal de Cultura, 1993. p. 31).

${ }_{129}$ CANDIDO, Antonio. Uma literatura empenhada. Formação da literatura brasileira. Belo Horizonte: Ed. Itatiaia; São Paulo: Edusp, 1975. v. I.
} 
próprias, que problematizam o conceito moderno de sujeito e o conceito de "eu" com que a própria poesia moderna europeia se media, mesmo quando o negava. A natureza da matéria histórica brasileira, que não é neutra, propiciou ao poeta Mário de Andrade a união da multiplicidade da subjetividade lírica da vanguarda europeia e a disparidade e heterogeneidade da matéria sociocultural local. São os "trezentos, trezentos-ecincoenta..." do poema de autodefinição "Eu sou Trezentos..." (de Remate de Males). É preciso frisar, entretanto, que essa multiplicidade nunca foi assumida em si mesma como fim, mas sempre como um meio, um percurso analítico de que viria uma síntese, uma unificação do sujeito lírico, da obra literária e do país, que se resolveriam por um processo homólogo. Como se lê na estrofe final de "Eu sou Trezentos...":

\footnotetext{
Eu sou trezentos, sou trezentos-e-cincoenta,

Mas um dia afinal toparei comigo...

Tenhamos paciência, andorinhas curtas,

Só o esquecimento é que condensa,

E então minha alma servirá de abrigo.
}

(versos 9-13)

Os versos são fazem o elogio do sujeito lírico múltipo, mas, em vez disso, vislumbram a possibilidade da identidade do sujeito consigo mesmo, identidade que, uma vez alcançada, pode ser esquecida por um sujeito lírico em paz consigo. O sentido da multiplicidade, então, é a unificação não violenta da disparidade e multiplicidade nacionais, em uma subjetividade igualmente formada por uma experiência reflexiva em contato com sua matéria histórica própria. O sujeito lírico se multiplica para se encontrar e, quando finalmente se encontra, muito menos que um triunfo da individualidade burguesa, ele desejará "servir de abrigo", ser uma forma de paz interior e de acolhimento. A subjetividade lírica deseja formar-se para poder se tornar fraterna. No entanto, esse sentido formativo da poesia de Mário, em que sujeito e nação se formariam de modo simultâneo e complementar, torna-se o seu problema axial, cujas soluções exigidas levam o poeta a tomar o rumo contrário ao desejado. A dificuldade desse percurso formativo pode ser observada nessa estrofe final de "Eu sou Trezentos...”. O olhar atento para algumas palavras usadas por Mário nessa estrofe abre o caminho para a análise da relação entre o movimento do sujeito lírico e o seu ideal formativo. A primeira é o verbo "topar". Evidentemente, o significado do verbo é o de "encontrar", o poeta quer dizer que um dia afinal encontrará a si mesmo. Mas o que 
justifica essa escolha lexical? O verbo "topar", além de sua inflexão oral e popular, possui em seu campo semântico o aspecto do imprevisto, de "dar de cara com", e sua etimologia confirma essa ideia, pois ela explica que o verbo surgiu da onomatopeia de choque brusco "top" mais a desinência verbal "-ar". ${ }^{130}$ Esse caráter imprevisto, por conseguinte, significa que o movimento da subjetividade e a sua formação não ocorrem de forma lógica e orgânica, mas dependem de uma "topada", de um fiat, melhor dizendo, de um tour de force, enfim. Outra palavra que chama a atenção é "andorinha". A significação desse pássaro no folclore brasileiro foi aproveitada poeticamente pelo próprio Mário em "Lenda do Céu" (de Clã do jabuti). A lenda indígena reza que um menino abateu uma andorinha, a qual lhe prometeu que, se não a matasse, ela o levaria ao céu. $\mathrm{O}$ menino aceitou, segurou-se às penas da andorinha e subiu. Chegando no céu, o menino encontrou familiares e amigos, e resolveu ficar se divertindo no céu para sempre. ${ }^{131} \mathrm{O}$ poema de Mário recupera novamente a lenda indígena, mas desta vez as andorinhas de seu verso são de voo curto, pela metonímia "andorinhas curtas". Com paciência, parecem dizer os versos, uma das andorinhas curtas (serão trezentas e cinquenta?) conseguirá levar o poeta ao céu, mudar qualitativamente o seu mundo. Tanto a escolha de "topar" como "andorinha" une a ideia de movimento com um acontecimento inesperado, seja fortuito ou mágico, para alcançar sua completude. Essa dificuldade de o movimento do sujeito lírico atingir o seu objetivo impele a subjetividade na poesia de Mário a tocar os seus extremos. Mas antes de chegarmos aos extremos dessa subjetividade lírica, podemos observar a natureza de seu desenvolvimento.

\section{Subjetividade Desdobrada}

As diversas ordens de estados de alma e propósitos que a subjetividade lírica de Mário de Andrade expressa exigem o seu desdobramento. A cada passo em que o poeta olha para dentro de si mesmo ou para o mundo exterior, surpreende-lhe um

\footnotetext{
${ }^{130}$ HOUAISS, Antônio; VILLAR, Mauro de Salles; FRANCO, Francisco Manoel de Mello. Dicionário Houaiss da língua portuguesa. Rio de Janeiro: Objetiva, 2007. p. 2.734.

${ }^{131}$ Outra referência popular à andorinha, esta uma superstição paulista, diz respeito à obtenção de dentes sadios: coloca-se o dente de leite da criança em cima do telhado e se diz: "andurinha, andurinha, levai meu dente, trazei-me outro, fais nascê dente". Tanto na narrativa folclórica quanto na superstição popular, a andorinha substitui qualitativamente alguma coisa: leva do mundo ao céu, substitui o dente caído por um dente sadio (CASCUDO, Câmara. Dicionário do folclore brasileiro. Rio de Janeiro: Ediouro, s/d. p. $77)$.
} 
descompasso, um tipo de desordem sistemática na natureza das coisas. Para apreender esse mundo de coisas desconcertadas, a subjetividade lírica adquire um movimento excessivo, o que joga contra o seu empenho programático de estabilizar uma originalidade brasileira e dar-lhe função social. Eis o paradoxo desta poesia: ela voluntariamente se faz plural para apreender o desconcerto, configurá-lo e lhe dar solidez, mas, na natureza de seu desdobramento, é a própria solidez que se perde. Dentro de um sem-número de tensões que a constitui, essa parece a tensão formal fundamental de sua poesia, à qual as demais estão essencialmente ligadas. Essa tensão vai buscar os meios poéticos para realizar-se, e a parte mais rica da obra poética de Mário de Andrade se configura como um sistema de soluções poéticas para esse desdobramento que não consegue figurar uma unidade. A solução recorrente, reconhecida por Roger Bastide e lastreada pelo próprio Mário, é a da dança. Em diversos momentos em que essas tensões se acumulam e se tornam insuportáveis, o poeta vai dissolver-se em dança, por vezes numa verdadeira dança de palavras, como veremos em momento posterior deste capítulo. Contudo, essa dissolução em dança é sobretudo um desafogo lírico, um empuxo de existência para além das determinações externas, que foge dos objetivos que o poeta previamente se deu. Nesse sentido, o aspecto dionisíaco de dança é a verdade de sua poesia, que desvenda em momentoschave a insuportabilidade das questões que ela carrega.

Assim, tentando obsessivamente compor-se por meio de matéria descompassada, Mário se polariza entre figuras que possuem um pouco mais de consistência: o $e u$ e o Brasil. A esfera subjetiva, como momento de negação do todo social, guarda um espaço em que o poeta pode manobrar sua fina observação da realidade, seus desejos pessoais e seus anseios coletivos, que, com frequência, confundem-se em seus poemas. O "Brasil", como imagem recorrente na história espiritual brasileira desde a Independência, é um nome que simboliza as demandas de completude de um conjunto social gelatinoso. Na frágil constituição de conceitos e imagens que deem um norte à compreensão de si e do outro ao longo da história brasileira, a recorrência de um recuo ao $e u$, anterior e posterior a Mário, e a obsessão com a totalidade que dê sentido ao conjunto, o país formado e bem definido, são pontos razoavelmente seguros de articulação. ${ }^{132} \mathrm{O}$ fato de

\footnotetext{
${ }^{132}$ Note-se que são esses os dois elementos que entram na "Canção do Exílio", de Gonçalves Dias. O tema do individualismo e do amor por totalidades abstratas como constâncias da vida mental brasileira é desenvolvido por HOLANDA, Sérgio Buarque. Raízes do Brasil (São Paulo: Companhia das Letras, 1995), principalmente o Capítulo VI - Novos Tempos. O enfoque que sigo aqui é, porém, um pouco diferente do exposto por Sérgio Buarque.
} 
se tratar do gênero lírico dá maior relevo à presença do $e u$, por ser categoria fundamental do gênero. ${ }^{133}$ Se isso por um lado facilita a questão, por outro a problematiza, pois de modo algum a esfera da subjetividade brasileira, embora hipertrofiada, se oferece como forma constituída, como síntese, para além dos constrangimentos de sua má-formação histórica. ${ }^{134}$ Portanto, a fragilidade do $e u$ e a aspiração do todo orgânico são polaridades que se articulam em favor de uma subjetividade lírica que se desdobra em busca de sentido. O eu e o Brasil, na poesia de Mário de Andrade, criam uma complementaridade de formas incompletas.

Toda a obra poética de Mário se desenvolve na busca de resolver esteticamente e mesmo extraesteticamente - essa questão. O elemento extraestético, como vimos no capítulo anterior, é frequentemente absorvido na forma, mostrando a flexibilidade com que o movimento ocorre no seio do desconcerto, na tentativa de abarcar e formalizar tudo que lhe possa conferir significação. Constantemente, a obra que se deu um destino na formalização da sua matéria histórica se vê confrontada com outro destino, imprevisto e hostil, mas a que o poeta não foge e, na formalização da dissolução, atinge momentos fortes de desvelamento de suas forças poéticas, como em "A Meditação sobre o Tietê".

Se o desdobramento constante fragiliza a subjetividade lírica por lhe negar a integridade a que ela tanto aspira, ele igualmente ganha em dinamismo de apreensão de movimentos subjetivos imprevistos e complexos, penetrando na heterodoxia que constitui a subjetividade do poeta e as formas de Brasil com que ela se depara e a que busca dar forma. Essa atenção aos momentos verdadeiros por que a subjetividade lírica passa nos poemas de Mário distingue o movimento da subjetividade desdobrada do movimento da oscilação constante e disparatada da veleidade e da volubilidade, constantes da vida subjetiva brasileira, e captada por Machado de Assis em muitas de suas personagens, Brás Cubas à frente. ${ }^{135}$ Mais do que, como Brás Cubas, flanar por todos os sentidos possíveis e disponíveis a um figurão que, sem precisar prestar contas,

\footnotetext{
${ }^{133}$ Embora sua presença no poema não seja de modo algum obrigatória.

${ }^{134}$ Sobre as subjetividades hipertrofiadas em nosso romance, por exemplo, Aurélia em Senhora, Brás Cubas em Memórias póstumas de Brás Cubas, Macunaíma em Macunaíma, Riobaldo em Grande sertão: veredas, ver PASTA JR., José Antônio. Changement et idée fixe (l'autre dans le roman brésilien). Cahier. Centre de Recherche sur les Pays Lusophones, Crepal, Paris, 2003. p. 159-171. Ver também SCHWARZ, Roberto. Um mestre da periferia do capitalismo. São Paulo, Duas Cidades/Editora 34, 1992.

${ }^{135}$ CACASO. (Antônio Carlos Brito). Alegria da casa. Não quero prosa. São Paulo: Editora da Unicamp; Rio de Janeiro: Editora da UFRJ, 1997. p. 186 e 191. O estudo sobre a volubilidade de Brás Cubas que aqui acompanho é de SCHWARZ, Roberto. Um mestre da periferia do capitalismo. São Paulo, Duas Cidades/Editora 34, 1992.
} 
usufrui do que lhe está a mercê: coisas, fatos e pessoas, transformando o privilégio em desfaçatez, a subjetividade lírica de Mário de Andrade dispõe o privilégio como busca de sua antítese, variação que busca significado, não que se faz significado ela própria. É assim que os poemas de Mário podem abarcar a doçura e a agressão, a entrega e o disfarce, intenso erotismo e pudor, vigor diante da corrente da vida e fragilidade liquefeita. Nesse dínamo formal, os poemas podem mimetizar os constrangimentos do individualismo na esfera do favor e do privilégio, levá-lo a tocar seus extremos e buscar deter-lhes pelo seu poder de formalização poética. $O$ desdobramento lírico da subjetividade por momentos que querem revelar sua verdade neutraliza o que a volubilidade do privilegiado tem de desfaçatez. Mário pode, desse modo, alcançar perspectivas diferentes do mesmo fenômeno, justapô-las e lidar com os seus diferentes aspectos. Essa variação do sujeito lírico, que deveria ser a trajetória da subjetividade em busca de um significado que a cessasse - o eu e o Brasil se fundindo e se complementando -, uma vez erigida em forma constitutiva, faz do desdobramento um anátema, e suas consequências serão sentidas de modo cada vez mais agudo pelo poeta Mário de Andrade.

Assim, o excesso de movimento da subjetividade lírica de Mário de Andrade, seu desdobramento, tem como lei que cada um de seus momentos revele algo do eu ou do mundo. Esse padrão de subjetividade poética foi inicialmente teorizado por Mário no “Prefácio Interessantíssimo" (Paulicéia desvairada) e em A escrava que não é Isaura. O sujeito lírico de então, para estar à altura do momento histórico, deveria se reger por dois movimentos opostos e complementares: multiplicar-se para abarcar o avanço tecnológico e a fragmentação das esferas da vida, e imergir em um campo desconhecido da própria subjetividade - o "subconsciente", lembrando que o modernismo internacional é contemporâneo e estreitamente ligado às descobertas da psicanálise. Esse duplo movimento da subjetividade corresponde a momentos distintos da vanguarda europeia: a exploração do eu pelo expressionismo, e que será retomado posteriormente pelo surrealismo; e a simultaneidade futurista e cubista, cujo último capítulo foi o construtivismo abstrato. Mário de Andrade recebe, pelo conhecido atraso periférico, os dois momentos de forma simultânea, e com dificuldade tenta entendê-los e mapeá-los, ${ }^{136}$ embora sua teorização modernista seja clara, devido em parte ao seu

\footnotetext{
${ }^{136}$ Sobre os momentos distintos da vanguarda: BOSI, Alfredo. História concisa da literatura brasileira. São Paulo: Cultrix, 1999. p. 336. Sobre a dificuldade de Mário, veja-se esse trecho de carta a Joaquim Inojosa: "Pra nós brasileiros é uma dificuldade enorme saber exatamente quais as teorias modernistas da
} 
caráter "eclético", 137 e em parte ao sentido de adequação à realidade brasileira. A síntese usada por Mário para definir sua estética modernista é a "verdade psicológica", ${ }^{138}$ que, obedecendo aos impulsos de um sujeito imerso em seu momento histórico, corresponderia tanto ao modo de apreender a simultaneidade externa como a escuridão e os momentos expressivos do próprio eu. ${ }^{139}$ Mesmo quando põe em segundo plano o lirismo subconsciente do $e u$ e privilegia a técnica, especificamente as formas poéticas da cultura popular, é a demanda de um significado que ilumine a vida do sujeito, social ou individual, que rege suas configurações estéticas.

Obedecendo à sua teorização inicial, mas ultrapassando-a, a subjetividade lírica mariodeandradiana faz esse duplo movimento girar sobre o eixo da realidade brasileira: a ação da multiplicidade do mundo tecnológico sobre o $e u$, apesar de incipiente na São Paulo dos anos 1920 - e talvez por isso mesmo -, dá lugar a um eu que se abre para os desconcertos da estruturação social e cultural brasileira. Nessa linha, Mário afia um procedimento vertical de toda a sua obra: a contraposição do país oficial, que se quer moderno à europeia, ao país real, que herda e repõe as características coloniais sem ajustá-las à modernidade desejada. Ao mesmo tempo, a expressão do eu, o aprofundamento em seus aspectos inconscientes, leva o poeta a buscar a própria fundamentação histórica do que é a subjetividade brasileira. Mário vai descobrir progressivamente que o processo de individuação burguesa, decorrente da diferenciação intersubjetiva e da autonomia das esferas sociais, ocorreu de modo incompleto no Brasil. A ampla liberdade de movimentos da subjetividade moderna, principalmente da subjetividade da poesia de vanguarda, em solo brasileiro, perceberá com surpresa e

Europa e dos Estados-Unidos, porque os livros que tratam delas, não são livros de exportação. É preciso ter essa paciência enorme de mandar buscá-los, catando aqui e além no jardinzinho das capelas artísticas o que há de mais importante e mais útil" (INOJOSA, Joaquim. O movimento modernista em Pernambuco. Rio de Janeiro: Gráfica Tupi, [1968-1969]. p. 339). Devo essa citação à leitura de CARVALHO, Lilian Escorel. A revista francesa L'Esprit Nouveau na formação das ideias estéticas de Mário de Andrade. 2 v. 2008. Tese (Doutorado em Literatura Brasileira) - Faculdade de Filosofia, Letras e Ciências Humanas da Universidade de São Paulo, São Paulo, 2008. A citação está na p. 54 da tese. Ainda para o modo como Mário dialogava com as vanguardas europeias, ver capítulo Arlequim e modernidade de LOPEZ, Telê Porto Ancona. Mariodeandradiando. São Paulo: Hucitec, 1996.

137 A expressão é "síntese eclética de periferia", de LOPEZ, Telê Porto Ancona. Mário de Andrade: ramais e caminho. São Paulo: Duas Cidades, 1972. p. 109. Para uma interpretação dos limites da teoria poética de Mário de Andrade, ver SCHWARZ, Roberto. Sobre o psicologismo de Mário de Andrade. A sereia e o desconfiado. Rio de Janeiro: Paz e Terra, 1981.

138 “... nossos princípios são em última análise realísticos e estamos ligados à verdade psicológica” [grifo meu] (ANDRADE, Mário de. A escrava que não é Isaura. Obra imatura. Belo Horizonte: Itatiaia, 1980. p. 286).

139 "Estou convencido que a simultaneidade será uma das maiores senão a maior conquista da poesia modernizante. [...] Esforçamo-nos em busca duma forma que objective esta multiplicidade interior e exterior cada vez mais acentuada pelo progresso material e sua representação máxima em nossos dias" (ANDRADE, Mário de. A escrava que não é Isaura, cit., p. 273). 
estranhamento a fragilidade de seus pressupostos e a fatuidade dos objetivos a que se dirige. Esse procedimento pode ser mais bem apreendido se nos detivermos separadamente em seus opostos dialéticos, o excesso e a falta.

\section{Excesso e Falta}

A poesia de Mário de Andrade é uma busca constante de superar essa contraditoriedade fundamental da subjetividade lírica, talvez a tentativa mais ambiciosa, mais empenhada e mais ousada de nossa lírica. Contudo, a matéria histórica e os materiais dispostos pelo sujeito lírico mariodeandradiano são ambos pertencentes a essa contraditoriedade, o que torna a sua poesia ambivalente, pois o combate à multiplicidade pela multiplicidade acaba sofrendo necessariamente seus efeitos, embora tentasse sempre reverter seu sinal, de uma multiplicidade inconsciente, abstrata, gozosa ou destrutiva, para uma multiplicidade que se reconhecesse e se desdobrasse em busca de sua própria superação. Mário de Andrade em momento algum vai se desvencilhar das consequências do aspecto excessivo da subjetividade. Essa disposição lírica excessiva pode ser observada mesmo nos momentos em que ela é menos evidente, como no seguinte poema:

\footnotetext{
Momento

$\mathrm{O}$ vento corta os seres pelo meio.

Só um desejo de nitidez ampara o mundo...

Faz sol. Fez chuva. E a ventania

Esparrama os trombones das nuvens no azul.

Ninguém chega a ser um nesta cidade,

As pombas se agarram nos arranhacéus, faz chuva.

Faz frio. E faz angústia... É este vento violento

Que arrebenta dos grotões da terra humana

Exigindo céu, paz e alguma primavera.
} 
A transfusão entre estado subjetivo e fenômeno climático ${ }^{140}$ presente de modo dramático neste poema retoma de certa forma a epígrafe de Frei Luís de Sousa a Paulicéia desvairada: "Onde até na força do verão havia tempestades de ventos e frios de crudelíssimo inverno". A verdade psicológica não se desliga dos aspectos do mundo exterior a que ela está vinculada, antes aproveita todas as associações metafóricas e metonímicas dessa captação subjetiva do ambiente. O que se nota nesses versos de tensão contida pela sobriedade da expressão é a tentativa de compreensão de um estado de coisas múltiplas, que retalha o sujeito em sua dimensão de natureza convulsa. $O$ poeta acompanha as mutações vertiginosas do clima, que não são exteriores, pois as emoções do sujeito lírico as acompanham. São três os momentos bem marcados no poema: a junção de sol, vento e um desejo de nitidez, embora a força dos elementos mutile o indivíduo; a melancolia dos trombones de nuvens, do frio e da angústia; novamente um vento, mas agora com uma força anímica e cósmica, exigindo transformação plena do curso das coisas, aquilo que ponha o mundo a salvo (a paz) e inaugure um novo florescimento.

Movimentos da natureza e da alma se conjugam e têm sucessões vertiginosas. Contudo, essa vertigem tem uma lógica. Ela se desdobra nas direções possíveis e nas configurações realizáveis, e, no entanto, bem marcados poeticamente, como são esses momentos, eles sempre aspiram a algo mais, um inalcançável que dê sentido ao todo. Não sendo encontrado, e o poeta não se contentando em criar um "Aleph" ou uma compensação imaginária, o poema reúne sua força desde as profundezas da terra, em um enorme esforço de realização, e se projeta como um anseio, um desejo de paz. Se o movimento é excessivo, o que subjaz a ele é a falta. É na ausência de uma realização plena, de uma configuração de síntese da subjetividade e do mundo, que o excesso de movimento se atualiza como necessário. Na busca de superar a própria precariedade, sanar sua carência, superar a si mesmo em sua contingência, o que aflora é a contradição permanente de excesso e falta. "Momento", então, cristaliza as tormentas da subjetividade excessiva e igualmente sua falta. Excesso e falta são a matéria da verdade psicológica da poesia de Mário.

\footnotetext{
${ }^{140} \mathrm{O}$ fato de o sujeito lírico não ser figurado explicitamente no poema de modo algum impede a identificação entre o movimento das imagens de um poema e o movimento de um eu implícito nos versos. A esse propósito, Mário comenta, em carta a Bandeira, a parte VIII do poema "Danças" como uma figuração do seu "eu" e, no entanto, a parte comentada por Mário em nenhum momento explicita o eu, e versa sobre as características e os movimentos de uma paisagem. Ver nota 184, p. 98 deste capítulo.
} 
Nesse sentido, podemos, com finalidade demonstrativa, visar aos momentos extremos de excesso e de falta na obra poética de Mário de Andrade, em que cada um dos termos do par contraditório se realiza como estruturante formal, e acompanhar seu desenvolvimento. Antes, é preciso contextualizar a subjetividade lírica de Mário de Andrade no curso histórico da subjetividade lírica moderna, para que fique mais clara a natureza estética e histórico-social desse movimento do sujeito lírico que estamos acompanhando.

\section{Subjetividade Lírica Moderna e Má-Formação do Eu}

O principal pressuposto da poesia lírica moderna é o poder reflexionante da subjetividade autônoma. A diferenciação entre o $e u$ e o mundo, mediada pela linguagem poética, abre um espaço de interioridade subjetiva, em que o eu é capaz de conhecer a si mesmo como sujeito, ao mundo como sua antítese, e a relação dialética entre esses dois polos. A primeira grande sistematização moderna da poesia, na Estética de Hegel, já apreende em sua filosofia dialética esse movimento reflexionante do sujeito que está na base da lírica romântica e que se estende para a lírica moderna: “Ao separar-se da objetividade, o espírito reclui-se em si mesmo, perscruta a sua consciência e procura dar satisfação à necessidade que sente de exprimir, não a realidade das coisas, mas o modo por que elas afetam a alma subjetiva e enriquecem a experiência pessoal, o conteúdo e a atividade da vida interior". ${ }^{141}$ Esse mundo da interioridade, característico da capacidade reflexiva do sujeito isolado, não somente faz o entendimento subjetivo das coisas do mundo, como, pelas características de sua sensibilidade poética e seu poder de expressão particulares, cria uma nova forma poética que guarda em si a forma do mundo remodelada pela experiência subjetiva, e também é capaz de revelar aspectos até então obscuros do mundo subjetivo e objetivo: "Se assim é, a exterioridade, externação ou saída do indivíduo para fora de si mesmo, só poderá ter o sentido de libertar a alma do seu estado de concentração direta, de um estado incompatível com representações mentais ou com palavras que a exprimam; graças à libertação, já a alma é capaz de se exprimir e dar aos sentimentos, até então obscuros, a forma de intuições e representações conscientes". ${ }^{142}$ A formação do sujeito lírico moderno, em sua

\footnotetext{
${ }^{141}$ HEGEL, G. W. Friedrich. A poesia lírica. Estética. Lisboa: Guimarães Editores, 1993. p. 607.

${ }^{142}$ HEGEL, G. W. Friedrich. A poesia lírica, cit., p. 607.
} 
constituição dialética de sensibilidade e entendimento, de interiorização do mundo e objetivação de uma forma, supera um suposto subjetivismo solipsista e já tem em si prefigurada a possibilidade de uma lírica capaz de preservar o espaço de liberdade subjetiva da interioridade, mas igualmente capaz de confrontar a realidade da vida social, entendendo o próprio espaço da subjetividade como elemento antagônico do todo social, e que pode decifrá-lo e adquirir em relação a ele uma perspectiva crítica. Tanto a doçura da voz da alma entregue a si própria, na espontaneidade livre de seu canto, quanto a subjetividade lírica minada pelo avanço do mundo administrado e consciente de sua problematicidade estão presentes, em diagrama, na Estética de Hegel. Dessa perspectiva de leitura, a dimensão do sujeito lírico reflexionante está no cerne da poesia europeia desde o Romantismo alemão até Baudelaire. Ainda na poesia de vanguarda, no momento em que a interioridade subjetiva, minada por todos os lados, lança suas últimas reservas em uma atuação direta na realidade objetiva, é a esse processo de constituição da subjetividade lírica moderna, e sua consequente desagregação, a que ela está se referindo.

Contudo, essa constituição da subjetividade lírica, cuja matriz prática é a constituição do sujeito moderno, é um processo, com dinâmica própria, que envolve essencialmente a emancipação do sujeito dos vínculos diretos e restritivos da natureza e da cultura. O percurso perfeito de constituição subjetiva como emancipação é somente um ideal mesmo na história europeia, em que a emancipação é mediada por um vínculo restritivo e dominador de segunda natureza - a forma mercadoria - na sua matriz prática, e, na esfera da individuação, pela transformação do ideal de emancipação em autoconservação subjetiva. Dentro desse ideal, entretanto, a individualidade mediada foi um avanço libertário e abriu potencialidades utópicas em toda a história europeia moderna. Fundamental para a compreensão da subjetividade lírica mariodeandradiana, cuja mediação é outra, é acompanhar o processo que a subjetividade moderna enfrentou para consolidar-se como conceito e como interioridade do sujeito lírico e observar seus momentos de indefinição diante de obstáculos objetivos. A liberdade poética do sujeito, para ser realmente liberdade, precisa encontrar na configuração e expressão de seus sentimentos e interesses pessoais a universalidade que os torne interesse de todos os homens. Caso contrário, o poeta recairia em frivolidades sem importância: "Mas, se é agradável que o poeta nos inicie nos seus estados subjetivos, não estamos de modo algum dispostos a escutar suas invenções particulares, a ser postos ao corrente das mais 
insignificantes paixonetas, dos trabalhos domésticos, de histórias de compadres e comadres". ${ }^{143}$ Uma subjetividade incapaz de ultrapassar seus interesses imediatos, seus impulsos libidinais ou suas ambições de prestígio dentro de um círculo restrito vai falsificar a natureza de sua interioridade e expressar uma liberdade abstrata, sem interesse humano. Somente a autoconsciência do indivíduo como indivíduo dentro de uma coletividade garante a verdade de sua expressão subjetiva:

\begin{abstract}
Com efeito, o que dá à poesia lírica conteúdo e forma, não são nem a coletividade objetiva, nem a ação individual, mas o próprio indivíduo enquanto indivíduo. Isto não quer todavia dizer que o poeta, para se exprimir liricamente, deva romper com os interesses e modos de ver do povo; tal decisão the daria apenas uma independência puramente formal e abstrata, e faria dele o joguete de paixões acidentais particulares, de desejos impulsivos, de sentimentos bizarros e de caprichos injustificados. ${ }^{144}$
\end{abstract}

Em outras palavras, fora do eixo da constituição subjetiva como emancipação da interioridade, cujo potencial libertário é alcançar a vida livre de todos os homens, a poesia lírica cai em um excesso de movimentos que não se sustentam, na falsa liberdade do sujeito suspenso no privilégio, na incapacidade, enfim, de adquirir consciência de si e da vida objetiva em que se insere. É nesse momento de má-formação da subjetividade lírica que se insere a natureza mesma da expressão lírica brasileira. O próprio Mário de Andrade, estudando Raimundo Correia, notou que nossos poetas eram "ventoinhas de princípios ocasionais". ${ }^{145}$ A impossibilidade de formação do sujeito autônomo, cuja relação com o outro fosse mediada, incorre em prejuízo essencial da universalidade, do poder libertário e da dimensão reveladora da forma da lírica. As relações interpessoais que não ocorrem por uma mediação objetiva, mas são frutos de relações de interdependência pessoal: favor, paternalismo, mando direto, violência, cordialidade que caracterizam, com peso diverso em cada fase, nossa história social e se repõem em cada uma de nossas modernizações conservadoras ${ }^{146}$-, deslocam o valor dos conceitos

\footnotetext{
${ }^{143}$ HEGEL, G. W. Friedrich. A poesia lírica, cit., p. 612.

${ }^{144}$ HEGEL, G. W. Friedrich. A poesia lírica, cit., p. 613.

145 ANDRADE, Mário de. Mestres do passado - III - Raimundo Correia. Apud BRITO, Mário da Silva. História do modernismo brasileiro. Rio de Janeiro: Civilização Brasileira, 1997. p. 266.

146 "A formação e a atividade de Mário, como também de seus companheiros de geração, dão-se num meio dominado pelos expedientes da proteção oficialista, que ditavam as virtudes e regras do estilo, além de definir as condições práticas de mobilidades da vida e da carreira literária, desde sempre propensa ao tráfico de prestígio, à convivência e à conformidade social, ao compadrismo, e demais soluções afins" (CACASO (Antônio Carlos Brito). Alegria da casa, cit.). Em outros termos, trata-se da reposição do ambiente intelectual elaborado por nosso liberal-escravismo clientelista do século XIX, do qual surge
} 
e das categorias literárias da literatura moderna, de que no entanto fazemos parte. ${ }^{147} \mathrm{~A}$ gênese histórica dessa subjetividade autônoma que não se forma converge e confundese com a própria gênese histórica da nação brasileira autônoma (que também não se forma). Essa gênese foi exposta por José Antônio Pasta Jr. a propósito de narradores e personagens principais de nossos romances centrais e, como reflexão históricofilosófica sobre a literatura brasileira, ilumina diretamente o dilema da constituição da subjetividade lírica na poesia brasileira. O trecho citado será longo, mas será preciso citá-lo todo, pela raridade do tema e da reflexão - embora sobre uma questão central de nossa literatura -, bem como pela clareza expositiva do texto:

Salvo engano, creio que é preciso postular uma verticalidade verdadeiramente radical da conjunção de capitalismo e escravidão no Brasil, no sentido em que esta última modela, ao fim e ao cabo, a constituição de toda subjetividade, e portanto, de todos os níveis sociais. Creio que, assim fazendo, chegaremos talvez a compreender melhor as metamorfoses do conjunto de nossas personagens, assim como algumas outras questões que restam inexplicadas e mesmo um tanto misteriosas em nossa cultura.

Dizendo de forma um tanto brusca, o problema poderia ser colocado assim:

Posta a conjunção de capitalismo e escravidão, cujos efeitos se fazem sempre sentir, cada indivíduo vê-se em face de dois regimes da concepção de si e da sua relação com o outro, dois regimes contraditórios, que logicamente deveriam excluir um ao outro, mas que se encontram um e outro bem presentes e bem atestados pela realidade da experiência. Por um lado, um regime antes de tudo moderno que corresponde, grosso modo, às relações capitalistas de produção, que prescreve a separação ou a diferença entre o mesmo e o outro; e, por outro lado, um regime que não reconhece a diferença entre o mesmo e o outro, no qual essa diferença é mesmo rigorosamente inconcebível, isto é, um regime que, por sua vez, corresponde aos laços do patriarcalismo escravista, nos quais o indivíduo não se reconhece verdadeiramente como tal, ou dito de outra forma, como algo realmente diferente de seu senhor, de seu grupo, de seu clã etc.

Em resumo, qual é a saída possível para uma subjetividade submetida simultaneamente a essas duas exigências contraditórias, quer dizer, à exigência de que ela seja distinta do outro, e, ao mesmo tempo, indistinta do outro? E, se se quiser, como estabelecer uma relação com o outro onde a alteridade é negada e afirmada ao mesmo tempo? [grifo do original]. ${ }^{148}$

nossa poesia propriamente nacional com Gonçalves Dias, com quem Mário de Andrade tem mais de um ponto de afinidade.

147 Acompanho aqui a ideia central do ensaio “As ideias fora de lugar". SCHWARZ, Roberto. Ao vencedor as batatas. São Paulo: Duas Cidades/Editora 34, 2000.

${ }^{148}$ PASTA JR., José Antônio. Volubilidade e ideia fixa (O outro no romance brasileiro). Tradução do original francês e organização de Cláudio R. Duarte (Sinal de menos, ano 2, n. 4, 2010. Disponível em: <http://www.sinaldemenos.org>. No original francês: PASTA JR., José Antônio. Changement et idée fixe (L'autre dans le roman brésilien), cit., p. 163-164. Não se devem subestimar os efeitos deletérios dessa conjunção de capitalismo e escravismo. No plano jurídico, por exemplo, a escravidão impossibilitou um 
A gênese, então, de nossa subjetividade está em nosso liberal-escravismo, que funda o nosso modo de ser. Mas o leitor há de se perguntar se, estudando uma subjetividade lírica como a da poesia de Mário de Andrade, que se liga a um ciclo posterior ao escravismo, que vai da crise da República Velha ao fim do Estado Novo (1922-1945), essa formulação de Pasta ainda tem validade. Carece a nossa crítica literária, a nossa historiografia social, os nossos estudos de psicanálise e as outras formas de reflexão que se voltam sobre o Brasil de respostas à altura do problema de como se configura a subjetividade brasileira pós-escravista. ${ }^{149}$ Se faltam análises consistentes, contudo, há um feixe de anotações esparsas e apontamentos iluminadores aqui e ali em nossas boas obras de reflexão, literárias ou não, que podem balizar a questão. Destes, retomo uma passagem de um estudioso da obra de Caio Prado Jr., sobre a organização social brasileira pós-escravista: “O que de mais importante se mantém da grande exploração é uma certa maneira de se tratar o trabalhador, identificado como praticamente o equivalente a um instrumento de trabalho. Dessa forma, o assalariado, que veio substituir o escravo com a abolição, encontrou o mesmo ritmo produtivo e estrutura econômica que existiam na época anterior". ${ }^{150}$ Sem o apoio de estudos mais completos, pode-se dizer, entretanto, que há na história brasileira uma perpetuação do "módulo escravista", que faz com que a subjetividade brasileira, na lírica e em suas demais configurações, reponha em outro contexto o seu dilema de origem. Além disso, e o mais importante para este estudo, a subjetividade cindida e incompleta, incapaz de reflexionar e alcançar autonomia, é um tema central na própria poesia de Mário de Andrade, facilmente verificável em sua leitura, posto e reposto pelo próprio Mário não

Código Civil em todo o nosso século XIX, pois o principal jurisconsulto do tempo sobre o assunto, Teixeira de Freitas, se recusa a legislar sobre escravos: "fique o estado de liberdade sem o seu correlativo odioso", dizia ele, só que o "correlativo odioso" era justamente a base da sociedade de então. Ver DUTRA, Pedro. A literatura jurídica no Império. Rio de Janeiro: Padma, 2004. p. 118. A partir de 1916, o Código Civil de Clóvis Beviláqua eleva todos os brasileiros, inclusive os pobres e descendentes de escravos, a "civis" de jure, mas desde então, e até hoje, qualquer um sabe que eles nunca foram (nem são) civis de facto.

${ }^{149}$ Um dos raros estudos que desenvolvem extensamente o assunto, mas de forma "estrutural" e não histórica, é DAMATTA, Roberto. Sabe com quem está falando? Um ensaio sobre a distinção entre indivíduo e pessoa no Brasil, capítulo do livro Carnavais, malandros e heróis. Rio de Janeiro: Rocco, 1997.

${ }^{150}$ RICUPERO, Bernardo. Caio Prado Jr. e a nacionalização do marxismo no Brasil. São Paulo: Departamento de Ciência Política da Universidade de São Paulo/Fapesp/Editora 34, 2000. p. 186. Desenvolvo essa mesma citação a propósito do poema "Acalanto do Seringueiro" no Capítulo V desta tese, p. 20. Outros textos que iluminam a questão da subjetividade brasileira pós-escravista são: SCHWARZ, Roberto. A poesia envenenada de Dom Casmurro. Duas meninas. São Paulo: Companhia das Letras, 1997, e os três capítulos finais de HOLANDA, Sérgio Buarque de. Raízes do Brasil. São Paulo: Companhia das Letras, 1995. 
apenas em seus poemas mas também no conjunto de sua obra de escritor e intelectual. Por isso, uma imersão na categoria filosófica do sujeito, entendida em seu processo constitutivo, se torna necessária para, na instabilidade de seus momentos anteriores à autonomia, captar a forma brasileira de subjetividade.

A condição de uma subjetividade que se sabe existente, mas que não consegue formar-se (reflexionar e adquirir consciência de si e do mundo), foi estudada também por Hegel no Capítulo IV, “A Verdade da Consciência de Si Mesmo", da Fenomenologia do espírito. ${ }^{151}$ A uma subjetividade incompleta corresponde uma consciência cindida. "Com a consciência de si entramos, pois, na terra pátria da verdade"; ${ }^{152}$ ora, é justamente a indeterminação dessa consciência de si que forma o núcleo do esforço combativo da poesia da Mário de Andrade: um esforço de combater a indeterminação, sua inverdade, e alcançar uma consciência necessária de si e do outro. Mas, antes, acompanhemos um pouco mais a inverdade dessa consciência cindida. A consciência de si que não concebe a diferença entre ela mesma e outra consciência, diferença esta que a limitaria e revelaria sua verdade, é apenas "consciência de si consigo mesma". ${ }^{153}$ A relação dessa consciência com a realidade objetiva é inorgânica: “o mundo sensível é para ela um subsistir, mas que é apenas um fenômeno, ou diferença que não tem em si nenhum ser". ${ }^{154}$ Em outro contexto, mas com significação análoga, Mário chamará a ausência de fundamento na realidade da vida mental brasileira de "desrelacionamento funcional". ${ }^{155}$ A consciência de si que não se define reflexivamente na relação com um Outro foi denominada por Hegel "consciência infeliz", uma consciência cuja impossibilidade de constituir-se cria formas próprias à sua cisão. Seu movimento é perene e não encontra finalidade: “Assim, essa consciência é um desvario inconsciente que oscila para lá e para cá, de um extremo da consciência-de-si igual a si mesma, ao outro extremo da consciência casual, confusa e desconcertante". ${ }^{156} \mathrm{E}$ prossegue: "Não consegue rejuntar em si esses dois pensamentos de si mesma: ora conhece sua liberdade como elevação sobre toda confusão e casualidade do ser-aí; ora torna a conhecer-se como recaída na inessencialidade e como azáfama em torno

\footnotetext{
${ }^{151}$ HEGEL, G. W. Friedrich. Fenomenologia do espírito. Petrópolis: Vozes, 2000. v. 1.

${ }^{152}$ HEGEL, G. W. Friedrich. Fenomenologia do espírito, cit., p. 120.

${ }^{153}$ HEGEL, G. W. Friedrich. Fenomenologia do espírito, cit., p. 120.

${ }^{154}$ HEGEL, G. W. Friedrich. Fenomenologia do espírito, cit., p. 120.

155 ANDRADE, Mário de. Evolução Social da Música no Brasil. Aspectos da música brasileira. Rio de Janeiro/Belo Horizonte: Villa Rica, 1991. p. 18 e 21.

${ }^{156}$ HEGEL, G. W. Friedrich. Fenomenologia do espírito, cit., p. 139.
} 
dela". ${ }^{157}$ Esse movimento de uma consciência cindida se multiplica infinitamente, e, ao mesmo tempo, seu contínuo mudar-se tem a fixidez monótona de um movimento sempre repetido: "ela tem uma dupla consciência contraditória da imutabilidade e igualdade; e da contingência e desigualdade consigo mesma". ${ }^{158}$ Quando, no momento em que a subjetividade agrupou suas energias para formar-se, mas, no seu movimento reflexivo, recusa-se ao momento de negação de si própria e reconhecimento do Outro (momento necessário para a consciência de si como diferença), essa força acumulada cinde a subjetividade em dois momentos contraditórios: o reconhecimento de si próprio como sujeito, capaz de reflexão, interioridade, separação do mundo e concepção autônoma de si mesmo e do mundo; e a negação do Outro como consciência de si, que o limitaria, a recusa a diferenciar-se do mundo e deixar de usufruir dele pelo movimento irresponsável e borboleteante da liberdade abstrata.

Sem passar pelos momentos de negação de si e de renúncia, fundamentais para o sujeito completar o movimento reflexionante que o forma, a subjetividade por um lado fica limitada a uma liberdade abstrata e inessencial, afastada da verdade de si e do mundo, por outro lado, seu movimento pode multiplicar-se ilimitadamente, chegando a velocidades vertiginosas $^{159}$. Adorno e Horkheimer, ao estudarem as etapas que deveriam ser vencidas no processo de individuação, observaram igualmente os estados limítrofes entre a individuação e o apelo de estágios anteriores à necessidade de o sujeito ser idêntico a si mesmo. Nesses estados limítrofes, a subjetividade, presa na fronteira entre a força da subjetividade burguesa e as promessas de realização animalizadas e regressivas de sua existência pré-histórica, poderá atingir todos os casos limites entre os instintos de autoconservação e autodestruição: ${ }^{160}$ o sono, o entorpecimento narcótico, o transe, o delírio, o gozo, o instante mortal. ${ }^{161} \mathrm{O}$ que sai danificado dessa condição contraditória é a própria existência de uma poesia autêntica, a própria possibilidade de

\footnotetext{
${ }^{157}$ HEGEL, G. W. Friedrich. Fenomenologia do espírito, cit., p. 139.

158 HEGEL, G. W. Friedrich. Fenomenologia do espírito, cit., p. 139-140. Reconhecido na literatura brasileira como estruturante formal de nossos grandes romances, o par "volubilidade e ideia fixa" é estudado por Pasta em PASTA Jr., José Antônio. Changement et idée fixe (l'autre dans le roman brésilien), cit.

${ }^{159}$ Como referência substancial desse tipo de movimento subjetivo na poesia brasileira, penso ser, salvo engano, esse procedimento o eixo estrutural da poesia de Murilo Mendes.

${ }^{160}$ Ver p. 101 deste capítulo, nota 191.

${ }^{161}$ Sobre a importância do instante mortal na configuração de obras capitais da literatura, do teatro e do cinema brasileiros, ver PASTA JR., José Antônio. Le point de vue de la mort (une structure récurrente de la culture brésilienne). PENJON, Jacqueline (Org.). Voies du paysage. Representations du monde lusophone. Cahier $14 \mathrm{du}$ Centre de Recherche sur les Pays Lusophones - CREPAL. Paris: Presses Sorbonne Nouvelle, 2006.
} 
dizer "eu". O que a subjetividade lírica sempre deveu ao privilégio ${ }^{162}$ ganha na poesia brasileira feição escarninha e irresponsável, porque explicitamente exclui a alteridade. Por consequência, na poesia de Mário de Andrade, a busca do "eu" é permanentemente busca do "outro", que lhe possa garantir uma subjetividade moderna, uma igualdade fundamental. ${ }^{163}$

Dança e Maleita

\section{Dança}

O movimento excessivo em sua forma pura, digamos, está na série de poemas denominada "Danças". A leitura da primeira parte, das nove partes que compõem o poema, já apresenta o padrão rítmico e psicológico em que as "Danças" se desenvolvem:

Quem dirá que eu não vivo satisfeito! Eu danço!

Dança a poeira no vendaval.

Raios solares balançam na poeira.

Calor saltita pela praça

pressa

automóveis

bamboleios

Pinchos ariscos de gritos

Bondes sapateando nos trilhos...

A moral não é roupa diária!

\footnotetext{
162 “... a própria subjetividade lírica deve sua existência ao privilégio: somente a pouquíssimos homens, devido às pressões da sobrevivência, foi dado apreender o universal no mergulho em si mesmos, ou foi permitido que se desenvolvessem como sujeitos autônomos, capazes de se expressar livremente" (ADORNO, Theodor W. Palestra sobre Lírica e Sociedade. Notas de literatura I. São Paulo: Duas Cidades/Editora 34, 2003. p. 76).

${ }^{163}$ Sobre a importância do Outro na poesia de Mário de Andrade, ver MAJOR NETO, José Emílio. A Lira Paulistana de Mário de Andrade: a insuficiência fatal do outro. 2007. Tese (Doutorado em Teoria Literária e Literatura Comparada) - Faculdade de Filosofia, Letras e Ciências Humanas da Universidade de São Paulo, São Paulo, 2007.
} 
Sou bom só nos domingos e dias-santos!

Só nas meias o dia santo é quotidiano!

Vida
Arame
Crimes
Quidam
Cama e pança
Viva a dança!
Dança viva!

Vivedouro de alegria!

Eu danço!

Mãos e pés, músculos, cérebro...

Muito de indústria me fiz careca,

Dei um salão aos meus pensamentos!

Tudo gira,

Tudo vira,

Tudo salta,

Samba,

Valsa,

Canta,

$\mathrm{Ri!}$

Quem foi que disse que não vivo satisfeito?

EU DANÇO!

À primeira leitura, a sensação causada pelo poema é a de um ritmo acelerado. Os versos frequentemente curtos, as associações rápidas e as quebras de referência dão ao leitor uma impressão de gira-gira que se sobrepõe inicialmente a todos os demais significados de "Danças". Como constância rítmico-psicológica, o poema pode ser resumido pelo verso: "Tudo é girar, tudo é rodar" (parte VI, verso 7), que ecoa os versos "Tudo gira/tudo vira/tudo salta" dessa parte I e cuja ideia ainda volta explicitamente na parte VII: "Eu sou feliz porque a Terra é uma bola./A bola gira,/Gira o universo,/Giro também" (versos 11-14). Contudo, essa primeira impressão, que não deve ser abandonada, tem de ser guardada provisoriamente, para que o contexto técnico da poesia modernista presente no poema possa ser mais bem compreendido. "Danças" parece realizar exemplarmente os pressupostos da poesia modernista expostos por Mário em A escrava que não é Isaura (livro escrito em 1922 e publicado em 1924). 
Nesse livro, Mário escreve: "Todas as leis proclamadas pela estética da nova poesia derivam corolariamente da observação do moto lírico". ${ }^{164}$ Essas leis tecnicamente são: verso livre, rima livre, vitória do dicionário. Esteticamente são: substituição da ordem intelectual pela ordem subsconsciente, rapidez e síntese, polifonismo. ${ }^{165} \mathrm{O}$ uso do verso livre e a busca de rapidez e síntese são as características que mais saltam aos olhos nessa parte I. As outras leis técnicas e estéticas, que num primeiro momento podem ser ofuscadas pela presença do ritmo do verso livre e da aceleração das imagens (rapidez e síntese), também são encontradas nos versos. A rima livre pode ser lida não apenas nos finais de versos: gritos/trilhos, dias santos/quotidiano, pança/dança, mas também como rima de sílabas iniciais, como: praça/pressa/aperto, em que as consoantes "pr" rimam perfeitamente nos primeiros dois versos e de forma mais vaga no seguinte. A vitória do dicionário é construída por um processo de evolução interna nas técnicas poéticas mariodeandradianas. O verso polifônico defendido no "Prefácio Interessantíssimo" (“Arroubos... Lutas... Setas... Cantigas... Povoar!...”) é verticalizado e transformado em estrofe: "Vida/arame/crimes/quidam", e o sentido construtivo do polifonismo horizontal se transforma em "vitória do dicionário", de palavras cujo poder poético não depende da sintaxe do verso, mas do significado e das sugestões de seu significado dicionarizado. As "leis estéticas" da poesia modernista segundo Mário são bastante próximas umas das outras, pois a exploração das associações livres do subconsciente ("substituição da ordem intelectual pela ordem subsconsciente") gera uma simultaneidade de sensações estéticas e modos expressivos ("polifonismo") ${ }^{166}$ que, pela depuração técnica da linguagem, se apresenta no poema como rapidez e síntese. Assim, como exemplo dessas "leis estéticas", poderíamos citar a parte I inteira ou qualquer par de versos escolhidos ao sabor do leitor. Mas essas leis técnicas e estéticas "derivam corolariamente da observação do moto lírico", que, pela sua natureza, é particularmente difícil de sondar. Nascido do "eu profundo", ${ }^{167}$ o moto lírico só é de fato poesia depois da sua elaboração técnica e formal, o que significa, dialeticamente, que na especificidade da forma poética está presente uma conformação subjetiva, uma "verdade psicológica". A multiplicidade técnica e estética da poesia modernista, então, não são, na esteira da teorização

\footnotetext{
${ }^{164}$ ANDRADE, Mário de. A escrava que não é Isaura, cit., p. 225.

165 Todos os termos são copiados de ANDRADE, Mário de. A escrava que não é Isaura, cit., p. 226.

166 "Polifonismo e simultaneidade são a mesma coisa" (ANDRADE, Mário de. A escrava que não é Isaura, cit., p. 256).

167 "O movimento lírico nasce no eu profundo" (ANDRADE, Mário de. A escrava que não é Isaura, cit., p. 208).
} 
mariodeandradiana, uma eliminação do sujeito na multiplicidade do mundo e da poesia, mas uma forma purificada de revelar uma verdade do "eu profundo". Assim, o sujeito na poesia modernista de Mário não é dissolvido e eliminado pela intertextualidade das formas e pela multidiscursividade do mundo, mas, ao contrário, polifonismo e multiplicidade são modos de presentificar o "eu", tirado da nebulosa do subconsciente e tornado universalidade poética. Até aqui caminhei com as categorias do próprio Mário, expostas em A escrava que não é Isaura, mas nesse momento, contudo, é necessário dar maior concretude ao psicologismo do "eu profundo" de Mário. Nascido do subconsciente, o moto lírico não é puro, como tampouco é pura a expressão subconsciente que se faz linguagem. Tanto a linguagem de um poema quanto a natureza de um movimento subjetivo já estão carregados com matéria histórico-social sedimentada, que lhes atribui significado e função, bem como lhes confere objetividade. Desse modo, a liberdade modernista do moto lírico é uma liberdade que lida tanto com matéria histórica e psicológica quanto com materiais linguísticos e culturais predeterminados. O significado estético do poema reside na concretude que nasce da dialética entre as liberdades do artista e a especificidade de sua matéria, subjetiva e verbal, e não da transmissão subjetiva e psicológica do moto lírico do poeta para a subjetividade do leitor. ${ }^{168}$ Pela especificação, então, da linguagem e do movimento subjetivo do poema, pode-se inquirir sobre seu significado estético e histórico. Buscando, nessa perspectiva, mapear a gênese técnico-estética de "Danças", é possível aventar a hipótese de o trabalho de linguagem de "Danças" ter sido sugerido pelo poema "Bailado Russo", de Guilherme de Almeida, também transcrito em A escrava que não é Isaura: ${ }^{169}$

\title{
BAILADO RUSSO
}

\author{
A mão firme e ligeira \\ puxou com força a fieira, \\ e o pião \\ fez uma elipse tonta \\ no ar, e fincou a ponta \\ no chão.
}

\footnotetext{
${ }^{168}$ Uma discussão sobre o mesmo tema, que segue outro caminho, pode ser lida em SCHWARZ, Roberto. O psicologismo na poética de Mário de Andrade, cit.

${ }^{169}$ ANDRADE, Mário de. A escrava que não é Isaura, cit., p. 241-242.
} 


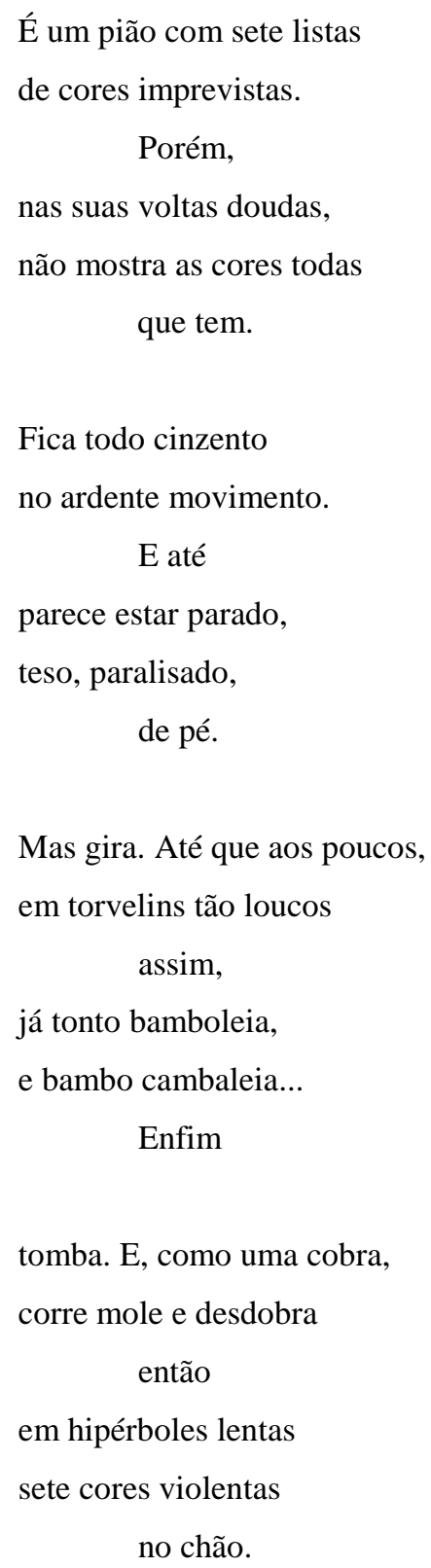

A respeito desse poema, Mário escreve a frase: "Substituição da ordem intelectual pela ordem subconsciente". ${ }^{170}$ Guilherme de Almeida busca reproduzir no ritmo do poema a sensação psicológica de um pião rodando, metaforizado pelo título, que alude a um bailado russo. Para isso, quebra o ritmo semântico do verso a fim de acompanhar o ritmo psicológico do giro, inserindo versos muito curtos nas estrofes, cuja sonoridade das rimas se sobrepõe à lógica da sintaxe. Com Guilherme de Almeida, Mário parece desenvolver a habilidade de substituir a subordinação do ritmo à sintaxe e semântica por uma preeminência rítmica e psicológica na composição do poema. Entretanto, se a

${ }^{170}$ ANDRADE, Mário de. A escrava que não é Isaura, cit., p. 242 [grifo do original]. 
coerência rítmica e psicológica dos versos foi sugerida por um poeta virtuose como Guilherme de Almeida, o padrão do movimento psicológico febril tem, certamente, outra fonte nesses primeiros anos de Movimento Modernista. Falo do poeta Luís Aranha. No aniversário de dez anos da Semana de Arte Moderna, em 1932, não houve qualquer comemoração. Porém, Mário de Andrade registrou esse aniversário de modo interessante, recuperando um poeta esquecido, Luís Aranha, no ensaio "Luís Aranha ou a poesia preparatoriana". ${ }^{171}$ Ensaio do maior interesse como fonte documental, como história do Modernismo e como reflexão estética, não poderei segui-lo aqui em toda sua riqueza, limitando-me à perspectiva da possível recuperação poética que Mário faz dos procedimentos do amigo poeta. Mário de Andrade nota na poesia do amigo um tipo de associacionismo de imagens cuja característica principal é a rapidez. Comenta ainda: “A rapidez em Luís Aranha não é uma adoção da moda modernista. Tecnicamente, é uma consequência fatal dos seus processos de poetar. E psicologicamente é uma sublimação terapêutica surgida desde as primeiras manifestações da sua poesia e atravessando ela inteira. O poeta ama as manifestações acalorantes, curativas da rapidez" [grifo meu]. ${ }^{172}$ A rapidez das associações de imagens, sendo técnica modernista, é reveladora de uma conformação psíquica particular. Mário ainda conclui: "Quanto à velocidade técnica não careço exemplificar. O Poema Giratório é um gasto voluptuário de velocidade, e uma das mais notáveis criações dinâmicas que conheço. O leitor observe como apressa gradativamente a leitura e se esbofa numa disparada formidável ao findar". ${ }^{173}$ Pois então observemos:

De noite estabeleço a ligação:

A terra eletrizada gira em torno do seu eixo

Terremoto

Maremoto

Bombas bolchevistas passando de mão em mão

Tôdas as pontes do mundo

\footnotetext{
${ }^{171}$ Publicado originalmente em PRADO, Paulo; ANDRADE, Mário de; MACHADO, Antônio Alcântara. Revista nova. São Paulo: Revista dos Tribunais, ano 2, n. 7, 1932 e republicado em Aspectos da literatura brasileira. Modernista original e de primeira hora, companheiro de discussões poéticas de Mário, Luís Aranha compôs seus poemas entre 1921 e 1923, e publicou alguns deles na revista Klaxon. Depois disso, "mandou a arte às favas e se fez burguês mansinho" (ANDRADE, Mário de. Luís Aranha ou a Poesia Preparatoriana. Aspectos da literatura brasileira. Belo Horizonte: Itatiaia, 2002). O conjunto de seus poemas foi publicado em ARANHA, Luís. Cocktails. Organizado por Nelson Ascher e Rui Moreira Leite. São Paulo: Brasiliense, 1989.

${ }^{172}$ ANDRADE, Mário de. Luís Aranha ou a Poesia Preparatoriana, cit., p. 80.

${ }^{173}$ ANDRADE, Mário de. Luís Aranha ou a Poesia Preparatoriana, cit., p. 80.
} 
Incêndio no Krenlin

Granadas, bombas, tiros de canhão se cruzam como confetti numa noite de carnaval

Explosão em mina de petróleo

Corpos de bombeiros a toda velocidade apitando no pavor da noite

Torres se estortegam no espaço e se abatem sobre ruínas

Todos os trens incendiados em desfilada pela linha propagam fogo nas florestas

Os edifícios dançam como ondas na tormenta

Os mares crescendo inundam os continentes

Portos destruídos pela inundação

Chamas de incêndio esbofeteando o céu

Chuva de petróleo alimentando o fogaréu do mundo

O mar de álcool pega fogo devorando todos os navios

Cinzas de vulcões soterrando os continentes

Chimborazo!

Os Andes desabam sobre a América do Sul

Explosões incêndios cataclismos

Chuva de fogo

Vulcões

Terremoto

Maremoto

E o mundo eletrizado gira furiosamente em torno do seu eixo confundindo todos os países...

("Poema Giratório", versos 404-430) ${ }^{174}$

Ao contrário da concisão e do trabalho de linguagem, esse trecho de Luís Aranha é uma disparada de associações psicológicas, enfaticamente psicológica em sua capacidade infinita de produzir imagens que se sucedem de modo vertiginoso. No poema prevalece um moto lírico febril que domina a linguagem sem elaborá-la cuidadosamente, atendendo, antes, à causa psicológica do poema no poeta e ao efeito psicológico do poema no leitor. É sugestivo que em seu texto sobre Luís Aranha, que recorda os dez anos da Semana de Arte Moderna, Mário de Andrade escolha como poema principal que é reproduzido no ensaio em seus 444 versos - o "Poema Giratório" [grifo meu], afinado em espírito ao movimento lírico presente em seu poema "Danças". Esse poema de Mário sintetiza em sua forma o moto lírico vertiginoso de Luís Aranha do final de "Poema Giratório" e o trabalho cuidadoso de linguagem de Guilherme de Almeida em

${ }^{174}$ ANDRADE, Mário de. Luís Aranha ou a Poesia Preparatoriana, cit., p. 104. Reproduzi fielmente a ortografia do poema. 
"Bailado Russo", poemas que Mário conhecia e admirava, bem como podem ter influído consciente ou inconscientemente na elaboração da "impulsão lírica" que gerou essas "Danças". ${ }^{175}$ Assim, operando uma primeira síntese de tendências da poesia modernista brasileira, podemos considerar "Danças" como um poema que realiza um "moto lírico" vertiginoso que o poeta coordena e dá forma pelo movimento de uma dança ou de várias danças, como sugere o título, e nessas danças o poeta dispõe de ritmo livre e palavras em liberdade (vitória do dicionário), procede por rapidez e simultaneidade, e, para concluir, consegue substituir a ordem intelectual por uma ordem subconsciente. A ortodoxia modernista do poema concentrou e ainda concentra a atenção da recepção para esse seu aspecto mais externo, como o fez o jovem Drummond, considerando "Danças" "um exemplar de pura poesia moderna". ${ }^{176}$ Contudo, essa ortodoxia modernista revela um traço estrutural da subjetividade lírica mariodeandradiana, que, retomando agora o movimento específico de "Danças", pode ser observado em sua parte III:

Filha, tu sabes... que hei-de fazer!
Nós todos somos assim.
Eu sou assim.
Tu és assim.
Dançam os pronomes pessoais.

Nunca em minuetes! Nunca em furlanas!

$\mathrm{EU}$

ELE

$\mathrm{TU}$

NÓS

ELES

Vós

Não paro.

Não paras.

\footnotetext{
${ }^{175}$ Outra referência importante, embora menos concreta quanto ao espírito e à linguagem, mas que daria, por assim dizer, o diapasão internacional do poema é o "Ma Danse", de Blaise Cendrars, que Mário cita como "exemplo magistral" da utilização do subconsciente na "aplicação poética do lirismo puro" em seu texto sobre o poeta franco-suíço. Ver ANDRADE, Mário de. Blaise Cendrars [1924]. In: EULALIO. Alexandre. A aventura brasileira de Blaise Cendrars: ensaio, cronologia, filme, depoimento, antologia, desenhos, conferências, correspondência, traduções. 2. ed. rev. e ampl. por Carlos Augusto Calil. São Paulo: Edusp/Fapesp, 2001. p. 388-389.

${ }^{176}$ SANTIAGO, Silviano (Org.). Carlos \& Mário. Correspondência de Carlos Drummond de Andrade e Mário de Andrade. Rio de Janeiro: Bem-Te-Vi, 2002. p. 60-62.
} 
Sucedem quadrilhas...

Gatunos!

Assassinos!

Ciganos!

Judeus!

Quebras formidáveis!

Riquezas fetos de cinco meses

Já velhas como Matusalém.

Baixistas calvos, rotundos, glabros,

Trusts de cana, trusts de arroz,

Açambarcadores de feijão-virado...

A Bolsa revira.

Reviram-se as bolsas.

As letras entram.

Os ouros saem...

Corrida

tombos

vitórias

delírios

banquetes

orquestras...

Os homens dançam...

Danço também

Nunca em minuetes nem bacanais!

Somos farândulas?

Somos lanceiros?

Somos quadrilhas?

Que somos nós!?

Pronomes pessoais.

Essa parte III desenvolve de forma radical o movimento de "Danças", seus versos fazem movimentos contínuos de giros e requebros, enfatizando essencialmente seu poder de mobilidade do sujeito lírico e da sua linguagem, sua possibilidade de desligamento das coisas com que mantêm contato. $O$ sujeito lírico não se relaciona com o mundo, mas consigo mesmo e com a natureza pulverizadora de sua linguagem. Há um fundo moral presente nessa parte, e em "Danças" de um modo geral, que condena o lucro e o movimento geral da riqueza, cujo processo acumulativo é identificado com 
hipocrisia e rapinagem: "Riquezas fetos de cinco meses/Já velhas como Matusalém”, e a presença de "gatunos", "assassinos", “judeus" identificados com a usura. Mas esse fundo moral é revertido em sarcasmo e pulverizado pelo movimento de gira-gira do poema. Como o poeta explica a sua interlocutora imaginária: "Filha, tu sabes... que heide fazer!/Nós todos somos assim”, ele também entra na dança geral do mundo e transforma a crítica moral em sarcasmo universal. Sarcasmo universal é o que Mário chamou em carta a Bandeira de "meu atual cinismo filosófico", 177 a respeito de "Danças". Esse cinismo filosófico se realiza por uma estratégia de desleixo conformista defendido cinicamente pelo poema e se infunde na própria linguagem, disfarçando-se na neutralidade da morfologia pronominal, que passa a reger um baile de máscaras do interesse. A transfusão de um mundo sentido como um carnaval de interesses egoístas na neutralidade de uma linguagem dessemantizada pela sua própria aceleração produz em seu desenrolar fônico uma coreografia de significantes ou uma "dança de palavras". Nela, a subjetividade se dissolve dionisiacamente no prazer material, sensual, das sonoridades. Acelerando o poema até neutralizar os significados das palavras, o poeta se entrega a uma rítmica de significantes. O procedimento poético é confirmado pelas palavras do poeta em carta de 1944 a Carlos Lacerda: “é a constância coreográficodionisíaca que atravessa toda a minha poesia, e para a qual Roger Bastide já chamou a atenção. Em quase todos os grandes momentos extasiantes, na dor ou na alegria, eu 'me dissolvo em dança", ${ }^{178}$ Significativamente, a dança, seguindo a reflexão de Paul Valéry sobre os quadros de Degas, é uma ordenação do movimento que nos torna o avesso de nós mesmos. O "estado de dança” é um "abandono hipnótico a uma espécie de furor". ${ }^{179}$ A dança, exilando-nos de nossa existência prosaica, nos lança a um ideal de vida mais fino, no limite de nossas possibilidades: "Um estado que não pode se prolongar, que nos põe fora ou longe de nós mesmos, e no qual, contudo, o instável nos mantém, enquanto o estável só figura por acidente, nos dá a ideia de uma outra existência perfeitamente

\footnotetext{
177 Carta de 15 de novembro de 1923. Mário escreve também: "Prego agora a filosofia do dar-deombros". MORAES, Marco Antônio (Org.). Correspondência Mário de Andrade \& Manuel Bandeira. São Paulo: Edusp/IEB, 2001. p. 104.

${ }^{178}$ ANDRADE, Mário de. A Carlos Lacerda. In: PAES, José Paulo. Sobre “O Carro da Miséria”. Revista do Instituto de Estudos Brasileiros, n. 36. São Paulo: IEB, 1994. Cronologicamente, a primeira manifestação da dança como dissolução de um movimento subjetivo que chegou a um ponto extremo está nessa estrofe do poema "Rua de São Bento", de Paulicéia desvairada: "Não tenho navios de vela para mais naufrágios!/Faltam-me as forças! Falta-me o ar!/Mas qual! Não há sequer um porto morto!/“Can you dance the tarantella" - "Ach! ya"/São as califórnias duma vida milionária/ numa cidade arlequinal...". ${ }^{179}$ VALÉRY, Paul. Degas Dança Desenho. São Paulo: Cosac \& Naify, 2003. p. 36. No original francês: Degas Danse Dessin. Oeuvres II. Paris: Gallimard, 1960 ("une sorte d'ivresse qui va de la langueur au delire, d'une sorte d'abandon hypnotique à une sorte de fureur. L'état de danse est créé", p. 1.171).
} 
capaz dos momentos que na nossa são mais raros, inteiramente composta pelos valoreslimites de nossas faculdades". ${ }^{180}$ O que é incompreensível, o que é inconciliável, o que se afigura como impossível é transfigurado na dança em uma ordenação cuja lógica é o movimento abandonado a si próprio, sem outra finalidade a não ser ele mesmo. ${ }^{181}$ Desse modo, a dança de palavras é uma forma de a subjetividade lírica de Mário de Andrade libertar-se de si mesma.

Ao longo das nove partes do poema, a "dança" permite ao sujeito abandonar-se a um furor que o desloca para fora de si mesmo, na definição de Valéry. Em seu momento de aceleração, então, o movimento subjetivo se volta sobre si próprio e revela sua lei de movimento. O desdobramento como busca da verdade se enfraquece e se torna puro movimento, que se realiza especificamente pela sua falta de sentido ou, dito de outro modo, de um movimento cuja única finalidade é o seu contínuo mover-se. Aqui, a falta vai mostrar-se como a verdade do excesso. O sujeito lírico, excedendo seu poder de mobilidade, se reverte em seu outro: a ausência de subjetividade. Essa verdadeira volatilização da subjetividade pode ser lida nos versos finais da parte II: "Tolos! A poeira sobe no ar.../O fumo sobe e morre no ar.../Eu vivo no ar!/Dançarinar!...", em que o sujeito lírico mariodeandradiano realiza aquela proeza dionisíaca formulada por Nietzsche: "Cantando e dançando, manifesta-se o homem como membro de uma comunidade superior: ele desaprendeu a andar e falar, e está a ponto de, dançando, sair voando pelos ares". ${ }^{182}$ Mas o que se configura como um superpoder da subjetividade poética, seu tour de force, é o seu verdadeiro contrário dialético. No limite de suas possibilidades, a subjetividade lírica se entrega àqueles, ainda segundo Nietzsche, "transportes dionisíacos, por cuja intensificação o subjetivo se esvanece em completo autoesquecimento". ${ }^{183}$ Com isso, a subjetividade lírica de "Danças" está configurada como uma forma-limite da subjetividade, em que o seu movimento subjetivo procura ultrapassar sua própria condição de sujeito. O que se percebe é uma subjetividade em

\footnotetext{
${ }^{180}$ VALÉRY, Paul. Degas Dança Desenho, cit., p. 37. Em francês: "Un état qui ne peut se prolonger, qui nous met hors ou loin de nous-mêmes, et dans lequel l'instable pourtant nous soutient, tandis que le stable n'y figure que par accident, nous donne l'idée d'une autre existence toute capable des moments les plus rare de la notre, toute composée des valeurs-limites de nos facultés", p. 1.172 [grifo do original].

${ }^{181}$ VALÉRY, Paul. Degas Dança Desenho, cit:: "Lá, na plenitude incompreensível da água que não parece opor nenhuma resistência, essas criaturas dispõem do ideal da mobilidade, lá se distendem, lá recolhem sua radiante simetria" (p. 38). Em francês, "Là, dans la plénitude incompressible de l'eau qui semble ne leur opposer aucune résistance, ces créatures disposent de l'idéal de la mobilité, y détendent, y ramassent leur rayonnante symétrie" (p. 1.173).

182 NIETSZCHE, Friedrich. O nascimento da tragédia ou helenismo e pessimismo. São Paulo: Companhia das Letras, 2007. p. 28.

${ }^{183}$ NIETSZCHE, Friedrich. O nascimento da tragédia ou helenismo e pessimismo, cit., p. 27.
} 
transe, o qual é criado pela aceleração dos movimentos subjetivos e pela dança de palavras. Pelo transe da dança, o sujeito lírico vive uma existência no limite, avesso da existência empírica, e consegue se desvincular das suas relações contingentes. $\mathrm{O}$ significado mais íntimo desse sujeito lírico de "Danças" é o mesmo que Mário notou a propósito de Luís Aranha: o poeta busca as manifestações acalorantes, curativas da rapidez. O motivo dessa busca é exposto pelo próprio Mário em carta a Drummond sobre a gênese de "Danças":

As "Danças" se escreveram por si num momento de cansaço e fraqueza. Estava exausto com a campanha de difamação que fizeram contra mim. Sofria muito. Minha inteligência começou a escrever e a dançar as "Danças". Em meia hora verdadeiramente aconsciente, estavam escritas as "Danças", que não sei quem escreveu. Depois o trabalho de poli-las que durou meses. Que tem ali muito de mim é certo. Revelam pra quem souber olhar um sofrimento muito doido. Não há alegria nenhuma nelas. ${ }^{184}$

Essa "campanha de difamação" é a dos primeiros anos do Modernismo, que abrange a primeira publicação em jornal de um poema de Mário, em $1921,{ }^{185}$ até o momento seguinte à Semana de Arte Moderna, 1922-1923. Muito significativo é o fato de que, antes de iniciar seus estudos sobre a cultura popular brasileira, principalmente por meio da música, Mário de Andrade faça contato com uma disposição profunda do comportamento artístico nacional. No Ensaio sobre a música brasileira (1928), Mário nota: "Nossa lírica popular demonstra muitas feitas caráter fogueto, serelepe que não tem parada. As frases corrupiam, no geral em progressões com uma esperteza adorável". ${ }^{186}$ Um pouco depois, em Música de feitiçaria no Brasil (1933), Mário

${ }^{184}$ SANTIAGO, Silviano (Org.). Carlos \& Mário. Correspondência de Carlos Drummond de Andrade e Mário de Andrade, cit., p. 67-68. Carta do ano de 1924, sem data. Ver também carta a Bandeira de 22 de novembro de 1924 sobre o mesmo tema: "O Graça [Aranha] está tão obcecado que acha as minhas 'Danças' alegres (é o que me diz por carta recebida hoje. Ora basta saber ler pra perceber a profunda amargura que há naquele cinismo exteriormente alegre. E o último verso? E toda aquela passagem do 'Há terras incultas além para longe', em que eu digo justamente que além do meu eu conhecido, cético, cínico, eu de encomenda, pra usar na rua, existe o outro meu eu, o verdadeiro, interior, que é caótico, sofredor, em perene formação como a terra amazônica?" (MORAES, Marco Antônio (Org.). Correspondência Mário de Andrade \& Manuel Bandeira, cit., p. 154).

${ }^{185}$ Trata-se do poema "Tu", presente em Paulicéia desvairada. O artigo é "O meu poeta futurista", publicado no Jornal do Comércio (Edição de S. Paulo), no dia 27 de maio de 1921. Republicado por SILVA, Mário da. História do modernismo brasileiro. I - Antecedentes da Semana de Arte Moderna. Rio de Janeiro: Civilização Brasileira, 1981. p. 227-231.

${ }^{186}$ ANDRADE, Mário de. Ensaio sobre a música brasileira. São Paulo: Livraria Martins, 1962. p. 46. A mesma agitação sem parada que faz a vivacidade da música popular leva, na cultura erudita, a uma incapacidade de deter-se sobre a própria natureza, a uma inépcia de autoconhecimento, uma "indisciplina mental", enfim, como o mesmo Mário notou ao ler com atenção, em 1921, o poeta Raimundo Correia: 
descobre o apelo constante da vida mental brasileira a movimentos repetitivos que resultassem em um efeito narcótico: "o que a psique nacional deseja é mesmo a repetição, a repetição inumerável que hipnotiza e embebeda". ${ }^{187}$ O que Mário descobria, baseado em estudos da religiosidade e da música popular, cujo correspondente erudito mais constante é o gosto pela embriaguez musical e retórica, ${ }^{188}$ pode ser entendido também como uma situação-limite de um sujeito que não se forma e que tem sua formulação mais pura - no conjunto da poesia mariodeandradiana - no poema "Danças".

A posição e o significado de "Danças" no conjunto da obra poética de Mário de Andrade não são os mesmos entre seu momento de gênese e finalização e o momento de sua publicação em livro. Em 15 de novembro de 1923, Mário escreve: “Acabei um poema. 'Danças"'. Quase um ano mais tarde, ele é publicado no primeiro número da revista Estética, de setembro de 1924, e recolhido com ligeiras modificações no livro Remate de Males, de 1930. Entre as primeiras duas datas de elaboração e publicação do poema em revista e a data do recolhimento do poema em livro, ele sofre uma notável mudança de significação simbólica na obra poética de Mário de Andrade. Se o poema fosse somente uma realização exemplar de poesia modernista, por que Mário o recolhe em livro em 1930, tendo antes publicado Losango cáqui (1926) e Clã do jabuti (1927)? Poemas como "Noturno de Belo Horizonte", publicado no número três da mesma revista Estética (1925) é recolhido em Clã do jabuti, bem como "Poema", publicado em Klaxon n. 6 (outubro de 1922) é recolhido em Losango cáqui. Sendo um poema fundamental de sua produção modernista dos primeiros anos, o que retardou seu retorno em livro? O motivo é que, embora plenamente realizado pela técnica e estética modernista, ele ocupou inicialmente na produção poética de Mário um caráter

\footnotetext{
"Compreendo e me comove a ânsia terrível dos que procuram a verdade e explodem na filosofia verdadeiramente lírica de um Farias Brito; admiro a ascensão ideal e sincera de um Bourget; sofro o contraste entre a fraqueza da carne e a elevação de espírito de um Musset; mas esse borboletear inconsciente por várias teorias religiosas ou apenas filosóficas, desde o mais negro pessimismo até o mais calmo cristianismo com um ramal para o ceticismo incolor, outro para o Budismo etc... com uma aparência muito frágil de sinceridade - isso não compreendo, nem me comove" (BRITO, Mário da Silva. História do modernismo brasileiro, cit., p. 266).

${ }^{187}$ ANDRADE, Mário de. Música de feitiçaria no Brasil. [1933]. Belo Horizonte: Itatiaia, 1983. p. 41. "[samba rural paulista] Nele tudo é dinamismo, tudo convida a não parar, tudo obriga a continuar indefinidamente. [...] Há mas é o convite às repetições intérminas, às repetições obsecantes que embebedam, entontecem, extasiam, exaurem" [1941] (ANDRADE, Mário de. Aspectos da música brasileira, cit., p. 181).

${ }^{188}$ Ver CANDIDO, Antonio. Formação da literatura brasileira. Belo Horizonte: Itatiaia, 1975. v. II. Especialmente p. 36-44, sobre música e retórica na constituição da sensibilidade romântica, que se projeta sobre a sensibilidade brasileira de um modo geral.
} 
circunstancial e de exceção, que respondia aos ataques sofridos pelo poeta. Ocorre que a publicação em revista de "Danças" é simultânea à ênfase nacionalista que Mário dará a sua obra, presente em "Noturno de Belo Horizonte" e que dura toda a década de 1920. Ao chegar ao ano de 1930, Mário afasta-se do que chamou de "nacionalismo pragmático", dada a vitória fácil e de consequências muito duvidosas do nacionalismo em poesia, ${ }^{189}$ e está novamente numa posição de isolamento e sofrimento, tendo sofrido, por um lado, os ataques da Revista de Antropofagia (2 $2^{\text {a }}$ Dentição, 1929) e, por outro, as incompreensões e inventivas do Modernismo carioca, seja pelo recém-convertido ao catolicismo Tristão de Ataíde, que identificava todo o Modernismo paulista ao primitivismo pau-brasil, seja pela desautorização de Mário como figura inaugural e proeminente do Modernismo levada a cabo pela revista Festa. Ao publicar Remate de Males, Mário supunha publicar seu último livro de poemas e pretendia mapear os momentos de sua produção poética. Assim, "Danças" cumpre uma função dupla no livro: registrar sua primeira produção modernista e reagir novamente a um sofrimento profundo, ${ }^{190}$ que, dada a conjuntura literária de então, já não mais se afigurava um momento de exceção. O sofrimento expresso num esgotamento subjetivo, num transe poético que corresponde a um momento circunstancial de 1922-1923, passa agora a figurar simbolicamente como sofrimento e esgotamento, operando no nível da organização de sua obra poética - como um momento de esgotamento subjetivo que corresponde a um momento da obra poética. O que se acompanha entre as duas publicações de "Danças" é a passagem do instante de sofrimento e exaustão biográfica ao momento da exaustão e sofrimento na organização de sua obra poética.

\section{Maleita}

Estudando as relações entre esclarecimento e mito, precisamente as "terríveis provações até que se formasse o eu, caráter idêntico, determinado e viril do homem", Adorno e Horkheimer notaram: "A embriaguez narcótica, que expia com um sono

\footnotetext{
${ }^{189}$ Mário escreve em carta a Drummond de 28 de fevereiro de 1928: "Pois esse tal de brasileirismo está me fatigando um bocado, de tão repetido e tão aparente. [...] Também publico o Macunaíma que já está feito e não quero mais saber de brasileirismo de estandarte. [...] Confesso que quando me pus trabalhando pró-brasilidade complexa e integral (coisa que não se resume como tantos imaginaram no trabalho da linguagem) confesso que nunca supus a vitória tão fácil e o ritmo tão pegável. Pegou. Eu estava disposto a dedicar minha vida pro trabalho. Bastaram uns poucos de anos" (SANTIAGO, Silviano (Org.). Carlos \& Mário. Correspondência de Carlos Drummond de Andrade e Mário de Andrade, cit., p. 321).

${ }^{190}$ A solução poética contemporânea a esse momento de sofrimento é o isolamento elevado e amoroso dos "Poemas da Negra" e "Poemas da Amiga", como demonstrarei no Capítulo III desta tese, p. 140-149.
} 
parecido à morte a euforia na qual o eu está suspenso, é uma das mais antigas cerimônias sociais mediadoras entre a autoconservação e a autodestruição, uma tentativa do eu de sobreviver a si mesmo". ${ }^{191}$ Na poesia de Mário de Andrade, essa embriaguez narcótica responde à subjetividade cindida, ao sujeito cuja reflexividade não se completa, devido às conhecidas reposições do atraso nos avanços da modernidade brasileira, cujas consequências atingem o cerne da constituição do sujeito moderno e das mediações sociais necessárias do eu lírico e de sua linguagem. De um lado, como acabamos de ver, a embriaguez narcótica é o ponto de chegada de um excesso de movimento, formalizado pelo poema "Danças"; de outro lado, porém, a poesia de Mário de Andrade também vai almejar um tipo de embriaguez narcótica que não ocorre pelo excesso de movimento, mas pela negação do movimento. A ausência de movimento buscada nesse outro polo da subjetividade mariodeandradiana é essencialmente um cultivo da falta de subjetividade em sentido moderno. Tendo em vista esse outro extremo, de que trata a sequência deste capítulo, observa-se, então, a estruturação formal dos extremos da subjetividade lírica na poesia de Mário de Andrade, e cumpre notar que as relações específicas entre a postulação de um sujeito moderno e sua anulação, que ocorrem de forma simultânea e podem caminhar, em sua obra poética, para uma aspiração à indiferença, que não deixa de ser um modo de embriaguez narcótica.

A aspiração à indiferença recebeu de Mário de Andrade um símbolo e um ambiente: a maleita e a Amazônia. Ambos estão presentes em "Rito do Irmão Pequeno", poema longo em dez partes, publicado em Livro azul, 1941, mas datado de 1931. O mundo amazônico aí comparece por imagens e símbolos que lhe são próprios. Inicialmente, porém, o poema não nos insere de imediato na ambientação amazônica, o que ele faz é apresentar-nos o eu lírico e seu interlocutor, como se lê em sua parte I:

Meu irmão é tão bonito como o pássaro amarelo,

Ele acaba de nascer do escuro da noite vasta!

Meu irmão é tão bonito como o pássaro amarelo,

Eu sou feito um ladrão roubado pelo roubo que leva,

No anseio de fechar o sorriso da boca nascida...

Gentes, não creiam não que em meu canto haja sequer um reflexo de vida!

191 ADORNO, Theodor W.; HORKHEIMER, Max. Dialética do esclarecimento. Rio de Janeiro: Jorge Zahar, 1985. p. 44. 
Ôh não! antes será talvez uma queixa de espírito sábio,

Aspiração do fruto mais perfeito,

Ou talvez um derradeiro refúgio para minha alma humilhada...

Me deixem num canto apenas, que seja este canto somente,

Suspirar pela vida que nasceria apenas do meu ser!

Porque meu irmão é tão bonito como o pássaro amarelo,

E eu quisera dar pra ele o sabor do meu próprio destino

A projeção de mim, a essência duma intimidade incorruptível!...

São duas as subjetividades presentes nesses versos: a do sujeito lírico, que se enuncia em primeira pessoa ("meu irmão") e a do irmão pequeno, conhecido nessa primeira parte pela sua qualidade, "tão bonito como o pássaro amarelo", e pela sua gênese, "ele acaba de nascer do escuro da noite vasta!". As duas subjetividades, entretanto, parecem compostas de naturezas antagônicas. Enquanto o irmão pequeno "bonito como o pássaro amarelo" surge como um símbolo de vivacidade: colorido, bonito, ágil e que pode cantar, o sujeito lírico é um eu que se retira do mundo e, nessa retirada, responde a dois estatutos: ele é um "espírito sábio" e uma "alma humilhada". A enunciação dos versos pertence ao sujeito lírico, que imprime neles a sua cadência lenta e longa, reflexo de sua queixa, de sua retirada do mundo, de certo ideal de repouso e silêncio, em que pudesse transparecer "a essência duma intimidade incorruptível". Se ao longo dessa primeira parte percebe-se que habitam os versos duas subjetividades de naturezas antagônicas, o ideal do sujeito lírico é que elas se identifiquem por meio da projeção desse mesmo sujeito, que dará ao irmão pequeno o sabor de seu próprio destino. $\mathrm{O}$ sujeito lírico do poema, enunciador dos versos segundo a natureza de sua própria subjetividade - a um tempo sábia e humilhada - pode ser conhecido pela dicção do poema e pelo quanto diz de si, mas quanto conhecemos do irmão pequeno? O que dele pode nos dizer sua qualidade e sua gênese? Sua qualidade, já foi dito, evoca grande vivacidade, mas sua gênese tem um poder evocador ainda maior: seu parentesco literário é com aquele "filho do medo da noite", Macunaíma. O irmão pequeno não é o Macunaíma porque, se ambos são filhos da noite, o personagem do romance é "preto retinto" e "uma criança feia". ${ }^{192} \mathrm{O}$ que familiariza os dois é a natureza noturna de sua gênese, bem como o que isso implica na obra de Mário. Essas condições de qualidade e

\footnotetext{
192 Todas as citações são de ANDRADE, Mário de. Macunaíma. O herói sem nenhum caráter. São Paulo: Martins, 1979. p. 9.
} 
nascimento evocam dois símbolos da obra de Mário de Andrade, que atuam nesse poema como complementares. O primeiro é a imagem da criança como momento de vitalidade plena, dos movimentos livres, da curiosidade sem fim. Defrontar-se com sua imagem infantil é o que faz o sujeito lírico em "Reconhecimento de Nêmesis" ( $A$ costela do Grã Cão), comovente acerto de contas entre a vida do homem maduro e as exigências da alma infantil. Igualmente criança, e este para sempre, é Macunaíma, personificação do movimento incessante. Esse mesmo Macunaíma faz a ponte entre os dois símbolos em questão, pois ele é a criança perpétua e nasce de uma noite vasta. A "noite" se constitui na obra de Mário como a hora da libertação dos instintos humanos e sua força. Além de Macunaíma, temos a "Maravilha de milhares de brilhos vidrilhos", que inicia a explosão de ideias e sentimentos no "Noturno de Belo Horizonte", e também a "emaranhada forma humana corrupta da vida" que brilha na água noturna, na noite líquida do Tietê, na "Meditação sobre o Tietê". ${ }^{193}$ O significado que Mário atribui à noite ou aos seres que em sua obra surgem da noite converge com o que o pensamento poético de Goethe denominou daimon, atualizando para o sujeito lírico moderno esse termo da filosofia socrática. ${ }^{194}$ Assim, o irmão pequeno, de acordo com minha análise, é o daimon do poeta, seu "gênio" no sentido socrático, personificação do seu excesso de forças vitais. O poeta separa, na enunciação do poema, seu poder de serenidade e repouso, que constituem o eu lírico, e as forças vitais de movimento e inquietação, que constituem o irmão pequeno. Nesse sentido, o irmão pequeno é o duplo daimônico do eu lírico, que nasce "do escuro da noite vasta" (parte I, verso 2). ${ }^{195}$

Essa parte I apresenta as subjetividades do poema e o padrão de relação entre elas projetado pelo sujeito lírico. As nove partes seguintes expõem essa relação como um processo. Dos poemas longos divididos em partes na obra poética de Mário de Andrade, este é o único em que há uma progressão lógica de uma parte a outra, em que há um ponto de partida e um ponto de chegada, com uma evolução dialética entre os

\footnotetext{
193 Sobre o símbolo da "noite" na poesia de Mário, ver CANDIDO, Antonio. O poeta Itinerante. $O$ discurso e a cidade. São Paulo: Duas Cidades, 1993. p. 268. Ver também Capítulo IV desta tese, p.180195.

${ }^{194}$ Em seu poema sobre as "palavras primordiais", as "Urworte", o daimon é a primeira a ser designada.

${ }^{195}$ Roger Bastide argumenta que dois traços principais e fundamentais caracterizam a poesia de Mário de Andrade: a dança e o diálogo. O primeiro traço, que calou fundo no próprio Mário, é constantemente utilizado nesta tese como elemento fundamental de sua poesia. Porém, nesse momento de entendimento inicial de "Rito do Irmão Pequeno", é necessário ressaltar o segundo traço, do diálogo: "Em segundo lugar [em primeiro vem a dança], seu lirismo é um diálogo. Enquanto para Carlos Drummond de Andrade, um mais um é igual a um, a dualidade conduz à unidade, para Mário de Andrade, ao contrário, um é igual a dois" (BASTIDE, Roger. Mário de Andrade [1940]. Poetas do Brasil São Paulo: Edusp/Duas Cidades, 1997. p. 79).
} 
dois. Os outros poemas de Mário que possuem essa forma, tais como "Danças", "Poemas da Negra", "Poemas da Amiga", "Girassol da Madrugada", "Grifo da Morte", são elaborados por um procedimento de variação expressiva entre as partes, mas não progressiva. Adiantando um pouco as conclusões da análise, para explicar a sua estrutura, afirmo que a finalidade do sujeito lírico é pacificar o seu daimon. É o ensinamento da indiferença maleitosa ao seu daimon que o poema expõe como um processo. Resumindo brevemente os passos do poema todo, de que recuperaremos posteriormente para análise das partes que mais interessam a este estudo: após o nascimento do irmão pequeno na parte I, o eu lírico o leva para caçar cotia na parte II, para que o cansaço bom o ensine o repouso indiferente. $\mathrm{O}$ desenvolvimento desse ensino é ritual, começando com a aprendizagem física da preguiça por meio do cansaço, passando pelo abandono da confiança no progresso (parte III), pela absorção do peso do passado e do ritmo lento da natureza (parte IV), culminando em um ritual propriamente dito, em que "bois pesados" são sacrificados para deixar "da gente o mundo tão longínquo" (parte V). A esse ápice ritual segue-se o "momento da dor", expiação necessária para se chegar à "coincidência vegetal" (parte VI). As três partes seguintes são expressões de um deleite maleitoso, exercício da preguiça “com vagar”. A preguiça domina a parte VII; a ausência de curiosidade, a parte VIII; a satisfação da "alma, à vontade", a parte IX. A parte X, que finaliza o poema, narra o dilúvio que toma o mundo da subjetividade, o período mítico intermediário, em que só os dois e as entidades míticas habitam o mundo, e o possível surgimento de um novo mundo.

Nesse processo ritual, o elemento mais necessário para a sua consecução pode ser lido na parte III:

Irmão pequeno, sua alma está adejando no seu corpo,

E imagino nas borboletas que são efêmeras e ativas...

Não é assim que você colherá o silêncio do enorme sol branco

O ferrão dos carapanãs arde em você reflexos que me entristecem.

Assim você preferirá visagens, o progresso...

Você não terá paz, você não será indiferente,

Nem será religioso, você... oh você, irmão pequeno,

Vai atingir o telefone, os gestos dos aviões,

O norteamericano, o inglês, o arranhacéu!... 
Venha comigo. Por detrás das árvores, sobrado dos igapós,

Tem um laguinho fundo onde nem medra o grito do cacauê...

Junto à tocaia espinhenta das largas vitórias-régias,

Bóiam os paus imóveis, alcatifados de musgo úmido, com calor...

Matemos a hora que assim mataremos a terra e com ela

Estas sombras de sumaúmas e violentos baobás,

Monstros que não são daqui e irão se arretirando.

Matemos a hora que assim mataremos as sombras sinistras,

Esta ambição de morte, que nos puxa, que nos chupa,

Guia da noite,

Guiando a noite que canta de uiara no fundo do rio.

O ritmo largo e cadencial do poema se compõe sobretudo de imagens. Acompanhar a composição imagética rica de sugestões do poema como um todo e dessa parte em especial se estenderia longamente em inegável deleite de fruição poética, mas é preciso renunciar aqui a esse deleite e limitar-se ao foco da análise, que é, necessariamente, mais restrito. O foco em questão é o comportamento da subjetividade lírica e, para tentar alcançá-lo, vou contornar as imagens e buscá-las na sua lógica no interior do poema, e não na explicação de cada uma. Então, se o movimento puro de "Danças" se relaciona de modo dialético com a anestesia, igualmente a indiferença em "Rito do Irmão Pequeno" se vincula diretamente com o excesso de movimento. Todo o esforço do poema é aquietar esse movimento. O objetivo do eu lírico é pacificar seu daimon, sua força demoníaca de transformação, de ambição e atuação no mundo. $O$ irmão pequeno transpira vitalidade, e o sujeito lírico percebe a semelhança entre tal vitalidade e o progresso material: "o telefone, os gestos dos aviões” etc. Para o eu lírico, tal vitalidade é um gasto que leva à autoaniquilação, pois ele imagina "nas borboletas que são efêmeras e ativas". Como solução, o poeta propõe ao irmão pequeno a imersão na terra amazônica, em que a paz silenciosa se reveste de maciez e calor. Essa imersão separará os dois - sujeito lírico e irmão pequeno - do espaço do mundo e do tempo da história. Ambos ficam salvos de uma espécie de tríade destrutiva: sedução (uiara), ambição (guia da noite) e morte (noite no fundo do rio). Imersos na solidão da terra amazônica, os dois podem "colher o silêncio do enorme sol branco". Esse enorme sol branco, antes de ser um puro símbolo poético, é uma transposição poética da 
experiência amazônica do poeta. Sua viagem ao Amazonas, de 1927, tem a seguinte passagem:

O calor vai subindo, vai subindo. O céu está branco e reflete numa água totalmente branca, um branco feroz, desesperante, luminosíssimo, absurdo, que penetra pelos olhos, pelas narinas, poros, não se resiste, sinto que vou morrer, misericórdia! O melhor é ficar imóvel, nem falar. E a gente vai vivendo uma outra vida, uma vida metálica, dura, sem entranhas. Não existo. ${ }^{196}$

Essa vida "outra", composta de indiferença e plenitude, é simbolizada na obra poética de Mário pela maleita. A "maleita" não é nomeada no poema, porém inscreve-se no cultivo da preguiça, na indolência consciente, em uma letargia pacificadora. A maleita, para o poeta, não é um tema entre outros, pois em diversos pontos de sua obra ele a coloca como um ideal da subjetividade:

... espécie de indiferença extasiada por tudo, que é o mais permanente característico do maleitoso. Uma calma incomparável, uma espécie de preguiça maravilhosa de ser, em que o próprio ar parecia com pouca vontade de ser ar, de ser imponderável, estava cheinho de partículas roseadas roçando pela mão da gente, pela boca, sem volúpia mas com uma doçura feminil. Ninguém que não provou tarde do Norte, tarde equatorial, não pode imaginar o que é serenidade [...]. Viver numa lentidão danada, naquele fim de mundo, atrasado do mundo pelo menos um mês em tudo, sem jornais, sem telefone, sem médico, pensando no que! Não pensando, numa preguiça organizada... [...] Por isso eu sonho com a maleita, que há-de acabar minha curiosidade e acalmará minha desgraçada vaidade de precisar ser alguém nesta concorrência aqui no Sul. ${ }^{197}$

No processo de desdobramento da subjetividade lírica aqui abordado, a maleita é a consequência do excesso de movimento, que em seu momento de saturação se torna um transe anestésico. A consciência poética de Mário intuiu e desenvolveu simbolicamente esse ponto a que a subjetividade lírica podia chegar. O cultivo da maleita e da preguiça é essencialmente o cultivo da falta, um processo rigoroso de vir-a-

\footnotetext{
${ }^{196}$ ANDRADE, Mário de. O turista aprendiz. Belo Horizonte: Itatiaia, 2002. p. 162. João Luiz Lafetá, em boa análise de "Rito do Irmão Pequeno", a que voltarei em momento posterior, dá pouca importância à experiência amazônica de Mário e enfatiza os arquétipos psicanalíticos das imagens. No entanto, chama com grande acerto a esse "enorme sol branco" de "luz de inexistência", que é um dos temas abordados nas etapas seguintes desta análise (LAFETÁ, João Luiz. Figuração da intimidade. São Paulo: Martins Fontes, 1986. p. 212).

${ }^{197}$ ANDRADE, Mário de. Maleita II. Táxi e crônicas no Diário Nacional. Belo Horizonte: Itatiaia, 2005. p. 363-365.
} 
não-ser. A verdade do excesso de movimento subjetivo, que é a sua incapacidade de formar-se organicamente, de encontrar a sua completude, a falta, portanto, é ela própria poetizada. Isso demonstra a alta consciência poética de Mário diante das suas pesquisas sobre o Brasil e o homem brasileiro - pois elas não se detêm em aspectos externos de nossa constituição -, descendo ao fundo de nossa própria constituição subjetiva e usando a si próprio como objeto de pesquisa. Esse mesmo procedimento de sujeitar-se como objeto da própria pesquisa é levado a cabo, em contexto psicanalítico, pelo próprio Freud, ao analisar os próprios sonhos, o que revela a radicalidade a que pode chegar em poesia o realismo psicológico.

A maleita como ideal da subjetividade lírica é rica de implicações e convida à reflexão teórica. Um sujeito poético que se predispôs a desdobrar-se em busca da verdade de si e do Brasil, e cujo ponto de chegada era a constituição simultânea da subjetividade lírica, da individualidade social e da integridade nacional, chega a um ponto extremo em que tudo isso é enfaticamente negado. É impressionante o poder de Mário de Andrade de configurar com riqueza os extremos a que pode chegar a expressão da subjetividade malformada. Pelo estudo já citado de Adorno e Horkheimer, aprendemos as principais tentações regressivas que o eu é chamado a vencer para se constituir, tentações que são verdadeiras promessas de felicidade, de comunhão não mediada com a natureza. ${ }^{198}$ A primeira, acompanhando o percurso de Ulisses de volta a Ítaca, em que se depara simbolicamente com cada uma das tentações, é o ato de comer o lótus. ${ }^{199}$ Esses "lotófagos" se revertem em um estado vegetativo, de uma vida "sem trabalho e sem luta", cuja existência é entorpecida e pacífica, em que os homens vivem "colhendo o lótus e esquecido[s] da pátria". ${ }^{200}$ A identidade entre o lótus e a maleita é incrível. Ambos correspondem a uma negação regressiva da civilização. Negam a barbárie, mas também negam a utopia civilizada. O preço dessa felicidade é a negação do progresso: "Essa cena idílica, que lembra a felicidade dos narcóticos, de que se servem as camadas oprimidas nas sociedades endurecidas, a fim de suportar o insuportável -, essa cena a razão autoconservadora não pode admiti-la entre os seus. Esse idílio é na verdade a mera aparência da felicidade, um estado apático e vegetativo, pobre como a vida dos animais e no melhor dos casos a ausência da consciência da

\footnotetext{
${ }^{198}$ ADORNO, Theodor W.; HORKHEIMER, Max. Dialética do esclarecimento, cit., p. 45.

${ }^{199}$ ADORNO, Theodor W.; HORKHEIMER, Max. Dialética do esclarecimento, cit., p. 67.

${ }^{200}$ ADORNO, Theodor W.; HORKHEIMER, Max. Dialética do esclarecimento, cit., p. 67.
} 
infelicidade". ${ }^{201}$ A maleita, como o idílio dos lotófagos, nega, sem antagonizar o curso da história, a própria História; ${ }^{202}$ nega, também, sem antagonizar, a dor e a racionalidade autoconservadora na formação do sujeito; nega toda e qualquer existência racional, humana, por fim. No entanto, regressiva como é, o encanto dessa existência sem violência não pode ser sonegado. Os homens, sob o peso da incorporação social, "não conseguem imaginar nenhuma felicidade que não se nutra da imagem dessa protohistória: 'assim prosseguimos a viagem, com o coração amargurado". ${ }^{203}$ A última fala é de Ulisses, ressentindo a renúncia à lotofagia. A nostalgia de estados anteriores de vida ocorre com mais pungência quando o peso da nova socialização é recente e tem os estágios anteriores como reminiscência. E mais, a lembrança do estágio anterior é sempre um parâmetro para medir o preço de violência e automutilação que a civilização exige dos homens que a compõem. O que está fora do sofrimento do tempo vivido sempre acena com uma promessa de felicidade, uma redenção simbólica e utópica. A utopia de uma humanidade livre da necessidade orientou a sociedade totalmente modernizada para a utopia civilizada, para o potencial libertador que continha a violência da racionalização, da socialização, da autonomia do sujeito. Nesse sentido, o pensamento de esquerda na Europa esclarecida pôde dialetizar o preço da racionalidade real com a promessa da racionalidade emancipada. No entanto, quando a racionalidade real se impõe sobre uma sociedade sem seus aspectos civilizados - formação do sujeito, dominação social mediada, universalidade de direitos e deveres -, ou seja, quando dificilmente se distingue a racionalidade do seu contrário dialético, a dominação e a barbárie, as promessas de felicidade regressivas, que se realizam a despeito do progresso, acenam com um poder de sedução revigorado. Assim, a maleita na poesia de Mário de Andrade é uma resposta poética a um tipo de progresso que mal se distingue da pura barbárie. Antes, de um progresso que se impõe pela via paradoxal da renovação ainda mais forte da barbárie. Dessa perspectiva, a preguiça maleiteira não reflete a poesia de uma sociedade que desconhece o progresso; ao contrário, é a expressão de um sujeito lírico e de uma linguagem que só conhecem o progresso, a cada passo de seu

\footnotetext{
${ }^{201}$ ADORNO, Theodor W.; HORKHEIMER, Max. Dialética do esclarecimento, cit., p. 67. Sobre o "narcótico das classes oprimidas", mas em chave mais desoladora, é instigante notar como o símbolo da maleita na poesia de Mário parece idêntico ao que foi o banzo africano na nossa história da escravidão. Banzo que foi para os escravos a última forma de suportar o insuportável.

202 "Ela remete à proto-história" (ADORNO, Theodor W.; HORKHEIMER, Max. Dialética do esclarecimento, cit., p. 68).

${ }^{203}$ ADORNO, Theodor W.; HORKHEIMER, Max. Dialética do esclarecimento, cit. O trecho entre aspas simples é uma citação da Odisséia.
} 
avanço, pela sua face bárbara. Nas paragens estagnadas da Amazônia, o que no fundo Mário expressa é o curso da história universal por uma sensibilidade de poeta brasileiro.

A articulação consciente de um processo poético que trabalha com elementos "antiprogressistas" supera seu aspecto fundamental de apego à "proto-história" e se configura também como uma forma de crítica histórica pela via da poesia, principalmente pelo ato de levar ao extremo a configuração regressiva da subjetividade que não se forma. Assim, o predomínio do verso livre extenso mantém, ao longo do poema, a disposição preguiçosa da subjetividade, mas a maleita não é o ponto de chegada do poema, pois o rito tem ainda outros passos para cumprir sua função.

\section{$\mathrm{V}$}

Há o sarcástico predomínio das matérias

Com seu enorme silêncio sufocando os espíritos do ar...

Será preciso contemplá-las, e a paciência,

Irmão pequeno, é que entreabre as milhores visões.

Nos dias em que o sol exorbita esse branco

Que enche as almas e reflete branqueando a solidão da ipueira,

Havemos de sacrificar os bois pesados.

O sangue lerdo escorre das marombas sobre a água do rio,

E catadupa reacendido o crime das piranhas.

Só isso deixará da gente o mundo tão longínquo...

As nossas almas se afastam escutando o segredo parvo,

E o branco penetra em nós que nem a inexistência incomparável.

A ambientação amazônica faz o enquadramento formal dessa parte $\mathrm{V}$ do poema, nas imagens e no vocabulário. O "predomínio das matérias" tem seu momento lexical com as pesadas "ipueira" e "maromba" (a primeira é o charco que se forma em lugares baixos, devido às enchentes dos rios; a segunda é um cabo ou corda para a travessia dos rios) e, no plano do significado, com os "bois pesados". A isso se soma a naturalização da linguagem, principalmente na segunda estrofe, em que "da gente" e "que nem" afastam qualquer resíduo de grandiloquência dos versos translúcidos. Nessa parte do poema, estamos imersos na terra amazônica. A Amazônia era para Mário de Andrade o grande sinal da nova civilização brasileira, coerente e orgânica, uma forma de corrigir a ambição progressista do Sul pelo ritmo lento e natural do Norte. Mistificação à parte, o 
poeta desenvolveu plenamente as sugestões que essa convicção, dúbia no plano político, podia render em termos literários. Explorada em sua dimensão vegetal, coerente em si própria e cuja lógica reproduzia em um plano mais elevado aquilo que a civilização humana apenas esboçava, a Amazônia cumpria para Mário, com cem anos de atraso, o que a natureza cumpriu, como crítica da civilização industrial, no Romantismo inglês de Wordsworth. Contudo, essa natureza organizada é disposta poeticamente para abrigar a falta, a subjetividade que paradoxalmente cultiva sua inexistência, seu processo de nãovir-a-ser. Ao contrário de Wordsworth, a subjetividade lírica de "Rito do Irmão Pequeno" em contato com a natureza amazônica não é uma subjetividade mais completa e reflexiva, cuja meditação faz o balanço da vida em uma emotion recollected in tranquility, ${ }^{204}$ mas uma subjetividade que se desfaz no seio da terra, operando um verdadeiro regressus ad uterum. Esse tema do regressus ad uterum foi notado por Lafetá a propósito do processo ritual do poema: "Em resumo: o poema narra uma experiência involutiva, as etapas progressivas da desmaterialização da realidade até o ponto em que se encontra um universo indiferenciado, primordial, de onde os seres renascerão". ${ }^{205}$ O regressus ad uterum é uma aproximação do limiar entre vida e morte, entre existência e inexistência. No processo poético de "Rito do Irmão Pequeno", ele é uma etapa no caminho de não-vir-a-ser. Esse ideal de inexistência, na poesia modernista, não começa com esse poema de Mário, mas tem um antecessor injustamente esquecido, Augusto Meyer, que em "Oração ao Negrinho do Pastoreio", em um sofisticado processo de subjetivação do folclore brasileiro, solta a súplica: "Negrinho santo, Negrinho,/quero aprender a não ser!" ${ }^{206}$ Aprender a não ser é o significado íntimo de "Rito do Irmão Pequeno", significado do qual Mário de Andrade desenvolve as possibilidades radicais. Como o poema apresenta o aprendizado do não ser, a subjetividade lírica em seu processo involutivo precisa se desfazer daquilo que a constituiu. Para Mário, era preciso abandonar o engajamento pelo Brasil, destruir a brasilidade de que se tinha nutrido: para isso, é necessário "sacrificar os bois pesados". O "boi” é na obra de Mário símbolo do povo brasileiro, principalmente em sua forma

\footnotetext{
204 WORDSWORTH, William. Preface to the second edition of several of the foregoing poems, published, with an additional volume, under the title of "Lyrical Ballads". The complete works of William Wordsworth. London: Macmillan and Co., 1905. p. 859.

${ }^{205}$ LAFETÁ, João Luiz. Figuração da intimidade, cit., p. 203. Contudo, não acompanho a análise de Lafetá em sua conclusão sobre o significado do regresssus, quando diz: "O horizonte do texto é o Nirvana - princípio e fim da vida, encontro e reunião sem dor de sujeito e objeto, descoberta da Divindade" (p. 203).

${ }^{206}$ MEYER, Augusto. Poesias 1922-1955. Rio de Janeiro: Livraria São José, 1957. p. 127.
} 
mítica de "Boi Paciência" presente nos poemas "Brasão" e "Meditação sobre o Tietê". ${ }^{207} \mathrm{O}$ sacrifício desses bois pode ser interpretado como a renúncia ao engajamento pelo povo brasileiro, pela pesquisa folclórica, pela reforma do Brasil. Sendo essas as diretrizes fundamentais da obra de Mário, compreende-se o caráter sacrificial profundo e verdadeiro que o poema opera. Com o regressus ad uterum, o sacrifício dos bois pesados e o processo de involução subjetiva, o poeta alcança seu ideal de não-vir-a-ser, e “o branco penetra em nós que nem a inexistência incomparável". As consequências desse ideal ainda são sentidas na parte VI, em que o irmão pequeno-daimon ressente o processo, exerce o "rito da agonia" para chegar à “coincidência vegetal”, pondo em prática um dos refrões de Mário: “a própria dor é uma felicidade". As delícias que resultam desse processo estão expostas nas partes VII, VIII e IX, em que o "exercer a preguiça, com vagar" aparece como uma inexistência edênica, o paraíso da "inexistência incomparável”. Cada imagem que compõe essas partes paradisíacas é um acerto estético de alta poesia, que mostra o rendimento de lirismo subjetivo e pesquisas brasileiras a que Mário podia chegar. O todo dessas partes edênicas cria um "Sailing to Byzantium" da subjetividade brasileira que, incapaz de ressentir em si os "monuments of unageing intellect" do poema de Yeats, pela sua incapacidade de constituição reflexionante, pode ainda alcançar as delícias da “inexistência incomparável”.

Se o poema terminasse na parte IX, Mário teria realizado uma luminosa - com luz de sol branco - superação brasileira do Brasil, em que a eliminação do todo não destruiria a felicidade individual. Seria, na afirmação de Lafetá, "a afirmação mitopoética do princípio de prazer". ${ }^{208}$ Porém, a parte X do poema, sua parte final, dá ainda mais um passo no rito, levando ao ponto máximo o significado íntimo do poema, até encontrar a sua contradição:

A enchente que cava margem,

Roubou os barcos do porto,

\footnotetext{
${ }^{207}$ KNOLL, Victor. Paciente arlequinada. Esboço de uma hermenêutica do imaginário na obra poética de Mário de Andrade. São Paulo: Hucitec/Secretaria de Estado da Cultura, 1983. Sobre as imagens do povo brasileiro: "De um lado, o jaboti como imagem do brasileiro exprime a sua diversificação e dilaceração o seu caráter arlequinal; de outro lado, o boi representa a totalidade dessa diversidade" (p. 150); sobre o Boi Paciência: "Podemos então dizer que o boi Paciência é a imagem do Pathos do povo brasileiro em seu modo de ser como sofrimento e paixão - e isto através de sua presença" (p. 153) [grifo do original]. ${ }^{208}$ LAFETÁ, João Luiz. Figuração da intimidade, cit., p. 216.
} 


\begin{abstract}
A água brota em nosso joelho
Delícias de solidão.

Trepados na castanheira

Viveremos sossegados

Enquanto a terra for mar;

Pauí-Pódole virá

Nas horas de Deus trazer

A estrela, a umidade, o aipim.

E quando a terra for terra,

Só nós dois, e mais ninguém,

De mim nascerão os brancos,

De você, a escuridão.
\end{abstract}

A contradição decorre do fato de que a inexistência, levada até o limite, em que o próprio mundo involui com o sujeito lírico, chega a um tipo de involução cosmogônica, e o resultado é a latência de um novo mundo, de uma nova gênese. As implicações mítico-religiosas do poema, do ritual de retorno a esse éden de indiferença são percebidas e desenvolvidas pela consciência poética de Mário. Nessa parte $X$, assistimos ao próprio momento do dilúvio, por um lado, cena bíblica de consciência cristã e, por outro, acontecimento cíclico das enchentes amazônicas. Enquanto o dilúvio não passa, a figura mítico-amazônica de Pauí-Pódole lhes levará “a estrela, a umidade, o aipim". O poema regride a um momento anterior à criação e, trazendo em potência um mundo novo, reagrupa as forças subjetivas, retoma a separação inicial do poema, e nesse mundo novo nascerão do eu lírico os brancos, homens vestidos da pureza matinal do dia, e do irmão pequeno nascerá a escuridão, lugar dos instintos indomados, das forças daimônicas. É notável a quantidade de deslocamentos, mesmo cosmogônicos, que a subjetividade maneja para poder não existir. A não existência, a falta, para poder se realizar, pressupõe movimentos tão ou mais ousados que o movimento puro de "Danças", e o seu ponto de chegada é a latência de uma nova vida, renovada. Mário de Andrade dá mais uma configuração original ao ciclo morte-ressurreição que é central em sua obra, em sua "constância coreográfico-dionisíaca", mas aqui em sua feição de “dionisismo cosmogônico", inspirado principalmente nos fenômenos das enchentes amazônicas, embora com eco do dilúvio cristão. No poema, é preciso observar que o ponto de chegada dialético do rito se reflete em uma mudança formal, em que a parte $\mathrm{X}$ 
quebra o ritmo do poema até então. É o próprio Mário que anota no seu "exemplar de trabalho" de seu livro Poesias (1941) a propósito dessa última parte do poema:

Depois de todo o lirismo sensível, caricioso, acariciante, quente e misterioso dos outros poemas [as partes do poema], uma ideia nítida dita com nitidez, implacável. A paixão, o lirismo desapareceram. O poema soa como um enunciado de verdade, uma fórmula matemática, em que não estou mais em mim. O poema é independente de mim. E é de fato feito por um outro. Tudo se modificou: ritmo, o próprio estilo da $1^{\mathrm{a}}$ e última quadra. Durante todo o poema eu sou um espírito que sabe. No último $\mathrm{X}$ sou um espírito mandado. Por quem? ${ }^{209}$

A pergunta final sugere o transe dionisíaco, em que a subjetividade passa por um autoesquecimento. Pode-se repetir aqui a mesma frase de Nietzsche usada a respeito do transe de "Danças", trata-se de um daqueles "transportes dionisíacos, por cuja intensificação o subjetivo se esvanece em completo autoesquecimento". ${ }^{210}$ Tanto o ritmo e a linguagem do poeta quanto a configuração da subjetividade lírica são modificadas nessa última parte, em que se finaliza o poema pelo ciclo morteressurreição do dionisismo. O regressus ad uterum já contém, como início de um processo, a potencialidade do ciclo dionisíaco, como explica Mircea Eliade:

Os mitos e ritos iniciatórios de regressus ad uterum colocam em evidência o seguinte fato: o "retorno à origem" prepara um novo nascimento, mas este não repete o primeiro, o nascimento físico. Especificamente, há uma renascença mística, de ordem espiritual - em outros termos, o acesso a um novo modo de existência (comportando a maturidade sexual, a participação na sacralidade e na cultura. Em suma, 'abertura' para o Espírito). A ideia fundamental é que, para se ter acesso a um modo superior de existência, é preciso repetir a gestação e o nascimento, que são porém repetidos ritualmente, simbolicamente; em outros termos, as ações são aqui orientadas para os valores do Espírito e não para os comportamentos da atividade psicofisiológica. $^{211}$

\footnotetext{
${ }^{209}$ ANDRADE, Mário de. Poesias completas. Edição crítica de Diléa Zanotto Manfio. Belo Horizonte: Itatiaia; São Paulo: Edusp, 1987. p. 44. Esse curto escrito de Mário sobre o "Rito do Irmão Pequeno" é um dos poucos momentos em que Mário não é o melhor guia para a compreensão de sua própria poesia. Se o trecho citado ainda mantém a clarividência do poeta, há outros que se desviam do poema propriamente dito, quando, por exemplo, identifica brancos com fortes e prepotentes, e pretos com fracos e escravos; ou quando diz que a parte X possui psicanaliticamente "a autopunição do burguês que se reconhece culpado" (p. 43). Não consigo chegar a nenhuma dessas conclusões ao ler analiticamente o poema. Com razão afirma o poeta "O poema é independente de mim".

${ }^{210}$ Ver p. 97 deste capítulo.

${ }^{211}$ ELIADE, Mircea. Mito e realidade. São Paulo: Perspectiva, 1972. p. 76 [grifo do original].
} 
O que explica Mircea Eliade, como estudioso do mito, foi dito, com palavras de poeta, pelo próprio Mário de Andrade a Manuel Bandeira, em carta de 28 de março de 1931, a respeito de "Rito do Irmão Pequeno":

A preguiça, a rede, a inatividade física provocam na gente uma espécie de rematerialização da parte intelectual do ser, de forma que a gente adquire de novo uma espécie de mentalidade primitiva (no sentido em que Taylor a concebe), e com isso cria ou vive de novo aquela prática de magia, que os primitivos têm, e deriva integralmente, não duma revelação superior, mas da coordenação, da associação das imagens fixadas na gente pelos fenômenos do mundo exterior. Vem disso o culto vegetal, universalizando por onde quer [que haja] seres humanos e consequentes magias provocando a queda da chuva no tempo da fecundação do grão. $^{212}$

Defrontando-se com a impossibilidade de existência de uma subjetividade autodeterminada, Mário de Andrade leva essa impossibilidade ao limite e, ao atingir a plenitude da inexistência, percebe nela a sua potencialidade negativa, a possibilidade de negação total do mundo e de refazer esse mesmo mundo por meio do mito dionisíaco, que é central em sua obra poética. Pode-se dizer, acompanhando as palavras do poeta, que, em "Rito do Irmão Pequeno", a maleita cria o grão, e o ciclo dionisíaco faz chover, abrindo a possibilidade de uma nova fecundação. Recomeçado o mundo, como o poema prevê, com as forças brancas da intimidade incorruptível e com as forças negras, noturnas, do daimon, o poeta não diz como será esse mundo, sabemos apenas que será um mundo outro, surgido da eliminação do mundo que conhecemos.

Em seus extremos, então, a subjetividade lírica de Mário de Andrade revela sua verdade psicológica fundamental, a relação dialética entre excesso e falta, tributária da má-formação da subjetividade na sociedade brasileira. O desejo da paz indiferente e o de reconstruir toda uma nação, percorrendo com a subjetividade a totalidade de suas expressões, são complementos necessários e estão implicados mutuamente. A principal força lírica de Mário de Andrade é trabalhar esses problemas com matéria histórica e materiais brasileiros, conferindo poder reflexivo às suas produções, pois esses materiais

\footnotetext{
${ }^{212}$ MORAES, Marco Antônio (Org.). Correspondência Mário de Andrade \& Manuel Bandeira, cit., p. 496. Os colchetes da citação estão no texto original.
} 
e essa matéria, refluindo sobre si próprios, mostravam sua verdade histórica e suas possibilidades mítico-históricas. O resultado poético é poderoso, fazendo com que elementos supostamente regressivos sejam levados ao seu limite e revertam no seu contrário. A estagnação amazônica e a dança narcótica, fora da forma artística, têm um valor diferente para a interpretação histórica, como índices do atraso e da perpetuação da via colonial. Incorporadas à elaboração poética, pelo movimento subjetivo extremado e paradoxal que as preside, ambas passam a operar em outro registro, reflexivo e autônomo, próprio da independência inconformista que demanda toda obra de arte autêntica. A função desses elementos, dança e maleita, na composição da paisagem social e cultural brasileira e na composição da poesia de Mário de Andrade é radicalmente diferente em cada um deles, embora a relação entre essas diferentes funções seja o seu nexo fundamental, que ativa a hermenêutica interpretativa e crítica. Não se trata, então, de adesão poética ao Brasil real, mas de um processo de destruição desse Brasil real e de recriação brasileira de um Brasil possível, em que atuam os extremos da subjetividade lírica, com o seu dionisismo fundamental. Esse processo destrutivo do Brasil decorre de uma demanda de libertação da própria subjetividade lírica, que só a alcança negando-se e recriando-se pelo mito, em que ressurge, em potência, libertada junto com a matéria e os materiais brasileiros de que se constitui. 


\title{
CAPÍTULO III - O AMOR
}

\author{
Assim, ao passo que um lado do corpo, rijo, quase reto, \\ dizia a virilidade guapa duma força crescente ainda, o outro, \\ apoiado na mesa, descansando quebrado em curvas de braço e joelho, \\ tinha uma graça e doçura mesmo femínea. \\ Mário de Andrade - \\ descrição do personagem Carlos, \\ de Amar, verbo intransitivo
}

Um sensualismo erótico medeia e, em certa medida, pacifica a relação de Mário de Andrade com os seus objetos de conhecimento. ${ }^{213}$ Como traço estrutural de sua obra, o poeta cria um tipo de conhecimento erótico, ou melhor, de uma erótica do conhecimento. Essa preeminência do erótico-afetivo ganha expressão própria, e mais complexa, quando seu objeto de conhecimento é um objeto amoroso. Nada mais distante de um erotismo momentâneo, que sente o impulso e busca satisfazê-lo, do que o erotismo na obra de Mário de Andrade. A bem da verdade, se eros está presente em seus poemas, não é ele que dirige a vida amorosa do poeta. Em termos de amor, seu grande sinal é a filia, o "amor-amizade", na divisão helênica das formas de amor. ${ }^{214} \mathrm{~A}$ filia é a mediação fundamental da disposição amorosa na obra poética de Mário de Andrade. ${ }^{215}$ Contudo, o eros represado e sublimado por vezes aflora, arrebatado e violento, em alguns momentos de sua poesia. A filia está no comando, mas o eros tem suas astúcias. A síntese que direciona o eros pela filia, a tensão entre os dois, e o transbordamento impetuoso do eros são estágios, do mais elevado ao mais telúrico, da expressão amorosa na poesia de Mário. Só o primeiro estágio é visado pelo poeta, os dois seguintes surgem como que a despeito de sua vontade, e sua elaboração poética faz parte daquela sinceridade total que Mário propugnava para o artista. Nessa verdadeira organização amorosa, seu procedimento inicial é a renúncia, num primeiro momento,

\footnotetext{
213 "Sou muito afetivo e por isso dedico um verdadeiro amor humano às coisas que me cercam" (ANDRADE, Mário de. Resposta ao Inquérito sobre mim pra Macaulay [1933]. Entrevistas e depoimentos. Organizado por Telê Porto Ancona Lopez. São Paulo: T.A. Queiroz, 1983. p. 39).

${ }_{214}$ Ágape é o amor-fé, Filia o amor-amizade e Eros o amor erótico. O conceito de filia está no diálogo Lisis, de Platão, que se complementa com os diálogos sobre o amor O banquete e Fedro.

${ }^{215}$ E não apenas na obra poética. Para Mário, o amor tem uma função hermenêutica, pois é a forma fundamental e mais elevada do conhecimento humano. Em seu curso sobre Estética Musical no fim da década de 1920, publicado postumamente, o amor-amizade preside a intenção artística, a obra de arte e o entendimento dela. Ver ANDRADE, Mário de. Introdução à estética musical. Organizado por Flávia Camargo Toni. São Paulo: Hucitec, 1995.
} 
que permite direcionar, posteriormente, a própria realização amorosa. Renúncia complexa, no caso, porque a essa disposição soma-se uma sobrecarga de impulsos eróticos. ${ }^{216}$ Até agora, a argumentação seguiu a natureza da disposição amorosa do poeta, excluindo propositadamente o comentário sobre a natureza do objeto amoroso e as mediações sociais que comparecem na sua elaboração. Se a disposição amorosa do poeta é rigorosamente ordenada, igual afirmação não se pode fazer a respeito de seu objeto amoroso. Em relação a este, estamos diante de uma sexualidade polivalente, inclinada a objetos amorosos diversificados, como se verá ao longo do capítulo. ${ }^{217}$ Em termos de conformação psicológica, não se pode esquecer o catolicismo do poeta, que projeta em seus poemas, por vezes, certo pudor do ato sexual. Complementar a isso, há também o aspecto da respeitabilidade de homem bem educado e de sociedade, imagem de origem biográfica que se projeta sobre o eu lírico. A renúncia, então, ocorre tanto como uma retenção das tensões, as quais se potencializam e se transformam em curiosidade inquietante e, em seu extremo, em um anestésico, quanto como uma repressão católica do prazer sexual e da bissexualidade de seu impulso erótico. ${ }^{218}$

A sobreposição desses conteúdos amorosos conforma uma poesia complexa e de múltiplas direções, cuja compreensão demanda captações distintas e complementares de

\footnotetext{
${ }^{216}$ Outras expressões da obra literária de Mário de Andrade se referem a essa disposição com clareza: "Há como que uma sem vontade do momento de gozo. Uma preguiça. Ora! Está-se tão bem assim sem gozar, gozando o sem gozar..." [1925] (ANDRADE, Mário de. Primeiro andar. Obra Imatura. Belo Horizonte: Itatiaia, 1980. p. 121); "A satisfação, como a felicidade, é um empobrecimento" [1941] (ANDRADE, Mário de. Aspectos da literatura brasileira. Belo Horizonte: Itatiaia, 2002. p. 216). Ver também FREUD, Sigmund: "É o destino do amor sensual extinguir-se quando se satisfaz; para que possa durar, desde o início tem de estar mesclado com componentes puramente afetuosos - isto é, que se acham inibidos em seus objetivos - ou deve, ele próprio, sofrer uma transformação desse tipo" (Psicologia de grupo e análise do Ego. Obras completas. Rio de Janeiro: Imago, 1969. v. XVIII, p. 146).

${ }^{217}$ Sobre o "pansexualismo" do poeta, ver o capítulo "O sublime inferno" de CASTRO, Moacir Werneck de. Mário de Andrade: exílio no Rio. Rio de Janeiro: Rocco, 1989. Esse livro foi muito produtivo na orientação do estudo do amor sexual na obra do poeta. Ver também p. 149-159 deste capítulo.

${ }^{218}$ Tento aqui desenvolver o tema freudiano da bissexualidade, em sua manifestação na poesia de Mário de Andrade, tendo como ponto de partida o que Antonio Candido denomina "impulso sexual irregular" (CANDIDO, Antonio. Pomo do Mal. O discurso e a cidade. São Paulo: Duas Cidades, 1993). Em seu estudo sobre "Louvação da Tarde", Antonio Candido refere-se ao símbolo da noite na poesia de Mário como correspondente, entre outras coisas, "à vida recalcada, aos desejos irregulares, ao inconsciente que assusta e a tudo que a sociedade oprime" (CANDIDO, Antonio. O poeta itinerante. $O$ discurso e a cidade. São Paulo: Duas Cidades, 1998. p. 268). Como impulsos ou desejos reprimidos, eles são um momento anterior à ascensão da bissexualidade à consciência. Uma vez percebida pela consciência, a bissexualidade pode dirigir-se para seus objetos próprios, em uma expressão poética refletida, e não imersa no subconsciente. Sobre a "disposição bissexual geral dos animais superiores", ver FREUD, Sigmund. Três ensaios sobre a teoria da sexualidade. Obras completas. Rio de Janeiro: Imago, 1969. v. VII. "Desde que me familiarizei com a noção de bissexualidade, considerei-a o fator decisivo, e, sem levar em conta a bissexualidade, creio que dificilmente seria possível chegar a uma compreensão das manifestações sexuais que podem efetivamente ser observadas em homens e mulheres" (p. 226). A expressão "impulsos sexuais irregulares", usada por Antonio Candido, consta nesse texto de Freud (p. 180).
} 
cada uma delas. Antes, podemos depreender, ainda no campo expositivo, algumas consequências dessa natureza pan-erótica - que se relaciona eroticamente com todos os objetos do mundo - e, ao mesmo tempo, sexualmente múltipla e reprimida. A renúncia pode implicar aspectos subjetivos diversos, dependendo da disposição do sujeito em relação ao mundo. Em sua vertente elevada, a renúncia conduz à sublimação, à retenção e à manutenção do objeto amoroso em uma atmosfera elevada e intangível, aspirando à completude do amor platônico. Contudo, a poesia amorosa de Mário de Andrade está sempre transitando entre os níveis de elevada espiritualidade e de uma vivência mais carnal e mundana. Nesta ponta, a renúncia não se sustém e busca uma compensação violenta, as "raivas de gozar" - do poema "Carnaval Carioca". Como a renúncia pode ser incompleta, o poeta leva a ambivalência ao extremo: se em relação a alguns objetos a renúncia é mantida, em relação a outros ela é suprimida e resulta na realização do desejo erótico.

\section{Pluralidade dos Desejos e das Sensações}

A preeminência do afetivo no conhecimento poético, que inclui em sua natureza um conhecimento social, racial e cultural na poesia de Mário, pode ser lida em "Carnaval Carioca". ${ }^{219}$ A ambientação não poderia ser mais própria. No carnaval convergem todos os elementos e materiais da vida social, todas as disposições sexuais possíveis e a mediação praticamente única da afetividade. A disposição inicial do sujeito lírico no poema é ambivalente. A boa educação à europeia do homem culto ligado à aristocracia de São Paulo se mistura com o fascínio por um mundo de liberdade e desejo, por certo primitivismo de um mundo sem repressões sexuais:

Carnaval...

Minha frieza de paulista,

Policiamentos interiores,

\footnotetext{
${ }^{219}$ Mais de uma vez Mário postulou o amor como forma de conhecimento ou como elemento fundamental dele: "Não pode haver crítica clarividente sem amor" (ANDRADE, Mário de. Álvares de Azevedo - I [1931]. Táxi e crônicas no Diário Nacional. Belo Horizonte: Itatiaia, 2005. p. 285); e "a inteligência artística, que há-de sempre funcionar impulsionada por um grande amor. [...] $\mathrm{O}$ amor é uma faculdade principalíssima da inteligência" [1945] (ANDRADE, Mário de. O banquete. Belo Horizonte: Itatiaia, 2004. p. 62).
} 
Temores de exceção...

E o excesso do goitacá pardo selvagem!

(versos 8-13)

O primeiro conflito é o da educação europeia com a sociabilidade popular no carnaval. O palco do conflito é privilegiado e reflete outro quadro: o da ideia de totalidade social de uma classe, cuja educação e visão de mundo seguem um padrão europeu, que se encontra com a sociabilidade de outra classe, a qual aglutina heterogeneidades sem uma diretriz de educação e comportamento que a defina à primeira vista. No carnaval, os elementos da vida brasileira que, à época, eram postos socialmente à deriva - as expressões populares de um modo geral - se encontram e se relacionam, bem como podem ser vislumbrados sem peias por um olhar que faça a inquirição do real na sociedade brasileira de então. Contudo, o poeta não vê esse palco somente da posição distanciada do observador curioso, do intelectual "redescobridor" do Brasil. Ele soma essa posição a outra, mais pessoal, de fruir pelos sentidos o que o carnaval tem a oferecer. ${ }^{220} \mathrm{O}$ poema, então, é conduzido por um sujeito lírico com uma dupla disposição: o entendimento frio, guiado pelo intelecto, que diferencia e reagrupa os traços populares de brasilidade que compõem sua maior festa, onde o "clã do jabuti", o Brasil, se une e de certa forma se integra; e a fruição sensorial, aberta às excitações da libido a que o sujeito está exposto em meio à festa. Sintetizando os dois pontos, haverá um entendimento libidinal, um conhecimento erótico ou erótica do conhecimento que atravessa o poema, e chega a transbordar dele.

De volta ao poema, a primeira figura que chama a atenção do eu lírico é um indivíduo, caixeiro de armarinho na Gamboa, mas que dança livremente fantasiado de baiana. A descrição do caixeiro/baiana é trespassada de um polimorfismo sexual, que parece refletir a ambivalência erótica do eu lírico. O indivíduo "gordo que nem matrona" (v. 31) e cujo peito cabeludo tem no "decote" "cascavéis sacoteando" (v. 34) montaria é, aos olhos europeus, uma imagem grotesca, híbrido de homem e mulher, de um aspecto lúbrico que dá ao homem traços de animalidade. No carnaval do poema, no entanto, esse híbrido ganha traços de beleza, mesmo um aspecto sedutor, pois sua boca é um "halo dos beiços carmins", imagem que mescla vulgaridade e elevação. E ainda

\footnotetext{
${ }^{220}$ A relação do toque pode também ser um desdobramento da relação de pertencimento, parte fundamental, segundo Mário, para o conhecimento: "é humanamente impossível se penetrar o sentido total do que não nos pertence" (ANDRADE, Mário de. Uma Suave Rudeza [1939]. O empalhador de passarinho. Belo Horizonte: Itatiaia, 2002. p. 69).
} 
nos beiços, o eu lírico nota uma "ruga longínqua", traço que abruptamente espiritualiza o caixeiro/baiana, vestindo-o de uma "angústia indistinta ignorante..." (v. 57). Essa espiritualidade quase espontânea completa a imagem de um homem que o eu lírico do poema recobre de afeto e coroa com erotismo, pois o poeta declara que só ele pôde gozar essa ruga longínqua e evoca, logo em seguida: "E talvez a cama de ferro curta por demais...” (v. 59). Importante notar como o conhecimento social e psicológico de um homem no carnaval se complementa de um conhecimento corporal que pode ser levado às últimas consequências.

Há um feixe de características heteróclitas que convergem e se aglutinam e se misturam no carnaval do poema, que o poeta mimetiza com uma linguagem alegre e viva, conduzindo por ela a animação da festa. A diversidade de elementos nativos e estrangeiros, a leniência dos olhares da ordem (policial, marido) sobre as liberalidades do carnaval formam um quadro muito vivo no poema. No entanto, como não se tem aqui a intenção de esgotá-lo, mas somente descrever a natureza das relações entre conhecimento e afetividade sensual na subjetividade lírica de Mário de Andrade, não me deterei nesses aspectos da relação estrangeiro/brasileiro, ordem/desordem no poema. Voltando, então, ao tema, essa mistura de conhecimento intelectual e dos sentidos se repõe no poema depois de uma rodada de observação do ambiente, quando o poeta primeiro declara suas intenções intelectuais, regidas pela distância civilizada do olhar:

\footnotetext{
Eu mesmo... Eu mesmo, Carnaval...

Eu te levava uns olhos novos

Pra serem lapidados em mil sensações bonitas,

Meus lábios murmurejando de comoção assustada

Haviam de ter puríssimo destino...
}

(versos 83-88)

No entanto, essa disposição poética de distanciamento, aprendizado e voz pura se soma a outra, que a complementa:

Ânsia heroica dos meus sentidos

Pra acordar o segredo de seres e coisas. 
O distanciamento não basta, pois a decifração exige, segundo o poeta, a aproximação sensorial. Nesse sentido, o propósito coletivo, público e modernista de descoberta do Brasil, de modernização da expressão poética pelo contato de vanguarda e realidade social periférica sofre a infusão de um anseio pessoal afetivo, de um erotismo que é subjetivo e particular, cuja intenção é a realização erótica de um sujeito específico. A aporia que se monta é a seguinte: a mistura de conhecimento pelo olhar e conhecimento pelo toque leva o propósito de desvendar o eu e o Brasil a um extremo, o que aumenta exponencialmente o poder de revelação dessa poesia. Contudo, o excesso de pessoalidade presente nesse conhecimento obstrui a sua revelação social objetiva, sua possibilidade de universalizar-se como conhecimento de todos os homens para todos os homens. Assim, digamos que o conhecimento, por ser distanciado $e$ sensorial, progride e regride ao mesmo tempo. É como se ao leitor fosse dado o acesso a uma parte desse conhecimento, e a outra parte fosse um convite à sensorialidade brasileira, a fazer, segundo seus apetites, sua própria experiência do toque. Então, se por um lado o poeta se lança com olhos livres, aptos a serem reeducados pela contraposição de experiências sociais e culturais diversas, a mobilizar um conhecimento contra um estado de coisas malformado, como é a estruturação social e cultural brasileira, por outro, é pelas brechas de informalidade (pelas brechas de sua natureza não formada) que o poeta complementa e, de certa forma, convida a complementar um conhecimento mais completo da vida brasileira. $^{221}$

O segundo momento mais propriamente erótico do poema é com uma mulher, que não é, ao contrário do caixeiro/baiana, descrita fisicamente. O que é descrito é seu poder sexual sobre o eu lírico. É na entrega aos impulsos libidinais do carnaval que o poeta a encontra, após a enumeração de diversas amadas históricas ("Semíramis Marília Helena Cleópatra e Francesca/Milhares de Julietas!” - versos 117-118), o que aumenta a carga erótico-literária do encontro amoroso. O toque é expresso por uma imagem telúrica: "Barreei meus lábios com o carmim doce dos dela..." (verso 125). Ao contrário da espiritualidade, meio espontânea, meio angustiada do objeto erótico anterior, a mulher aqui em questão é toda carnal. O amor é feito de “desejos irritados” (verso 126),

\footnotetext{
221 A nota sensorial faria parte, talvez, de um traço decisivo de nosso modo de ser, de explícitas conotações de amor doméstico e familiar: "precisão de carinhar, tão brasileira" (ANDRADE, Mário de. Terminologia Musical [1933]. Música, doce música. Belo Horizonte: Itatiaia, 2006. p. 54), cujo conteúdo meio regressivo de transpor para a vida social aspectos da vida familiar é, ao contrário, sentido pelo poeta como uma compensação: "a doçura, apesar de tudo, desta nossa vida brasileira" (ANDRADE, Mário de. Conversa à Beira do Cais [1938]. Os filhos de Candinha. Belo Horizonte: Itatiaia, 2006. p. 28).
} 
há relação da posse amorosa, o torpor da realização, e a volta do desejo, numa relação amorosa que é um "mel que não sacia". A relação amorosa relativamente convencional ganha vibração própria pelas imagens com que é apresentada no poema:

Teu amor provinha de desejos irritados,

Irritados como os morros do nascente nas primeiras horas da manhã

Teu beijo era como o grito da araponga.

Teu abraço era como a noite dormida na rede

Que traz o dia de membros moles mornos de torpor.

Te possuindo, eu me alimentei com o mel dos guapurus,

Mel ácido, mel que não sacia,

Mel que dá sede quando as fontes estão muitas léguas além,

Quando a soalheira é mais desoladora

E o corpo mais exausto.

(versos 126-136)

A expressão amorosa é montada com imagens e léxico brasileiros: a geografia irregular dos morros como expressão dos desejos irritados, o beijo como grito da araponga, o abraço como noite dormida na rede, o mel específico da árvore guapuru e a desolação de geografias que abrem enormes distâncias para a obtenção de um objetivo. Com astúcia, o poeta dá colorido novo a uma relação amorosa convencional em pleno carnaval.

As duas relações eróticas do poema, uma realizada, a outra, ao que parece, desejada, fundem sexualidade ambivalente e conhecimento psicológico, cultural, social e de linguagem, e, como síntese, a necessidade de complementar o conhecimento intelectual pelo conhecimento do toque. Quando o poeta se distancia do calor da festa e passa a ser apenas um observador, não obstante seus traços de voyeur, a meditação isolada retoma, ainda que atenuados, traços de culpa cristã. Às histórias de pecado, o poeta gostaria de contrapor as "parábolas lindas" dos padres antigos (tempo de Felipe Néri, padre florentino do século XVI, conhecido por sua bondade e piedade, que foi canonizado). E esse impulso de cristandade renovada se torna progressivamente uma prédica e uma louvação, tentativas de recuperar a festa dos desejos na esfera de um mundo mais puro (versos 214-230). A desordem organizada pelo carnaval, por definição heterogênea, é recuperada em uma ordem purificada e centralizada, que emana de Deus e se irradia sobre o mundo, como uma bênção. Essa religiosidade de 
Mário de Andrade, de origem católica, entretanto, se abre para o ecumenismo de um sentimento religioso da vida, pois se a prédica e a louvação têm as marcas da linguagem religiosa, ligando expressão ecumênica e matriz católica, em um ponto anterior do poema, essa religiosidade da vida vai ser observada na dança espontânea de uma negra “em baixo do Hotel Avenida em 1923”:

\begin{abstract}
A moça mais bulcão polido ondulações lentas lentamente
Com as arrecadas chispando raios glaucos ouro na luz peluda de pó.

Só as ancas ventre dissolvendo-se em vaivéns de ondas em cio.

Termina se benzendo religiosa talqualmente num ritual.
\end{abstract}

(versos 145-149)

Sobre essa dança da moça entregue a si como em um ritual, Mário escreve em carta a Drummond de 10 de novembro de 1924:

... um fato a que assisti em plena avenida Rio Branco. Uns negros dançando o samba. Mas havia uma negra moça que dançava melhor do que os outros. Os jeitos eram os mesmos, mesma habilidade, mesma sensualidade mas ela era melhor. Só porque os outros faziam aquilo um pouco decorado, maquinizado, olhando o povo em volta deles, um automóvel que passava. Ela, não. Dançava com religião. Não olhava pra lado nenhum. Vivia a dança. E era sublime. Este é um caso em que tenho pensado muitas vezes. Aquela negra me ensinou o que milhões, milhões é exagero, muitos livros não me ensinaram. Ela me ensinou a felicidade. Bom! Não é preciso ninar a vida pra ser feliz dentro dela. ${ }^{222}$

A religiosidade, então, é uma entrega espiritualizada aos atos da vida. ${ }^{223} \mathrm{~A}$ religiosidade católica do poeta remete a espiritualidade da vida a uma irradiação divina, e no momento em que a libido do carnaval arrefece, é ao Altíssimo que ele volta os olhos, buscando espiritualizar sua experiência. O Senhor é convocado a pairar sobre as "festanças virtuosas e gozos ilegítimos" (v. 221), e, como síntese, o poeta faz a infiltração da pluralidade carnavalesca na louvação ao Senhor, e da pureza deste naquela. Com isso, a espiritualidade originariamente católica do poeta e a multiplicidade de sensualismos brasileiros são elementos do poema que buscam uma síntese, e essa síntese é feita pela união de Baco e Deus, de religiosidade e realização dos instintos: um dionisismo espiritualmente elevado. É como se a filia do poeta se

222 SANTIAGO, Silviano (Org.). Carlos \& Mário. Correspondência de Carlos Drummond de Andrade e Mário de Andrade. Rio de Janeiro: Bem-Te-Vi, 2002. p. 48-50.

${ }^{223}$ Esse é o tema do Capítulo IV desta tese. 
dirigisse ao povo brasileiro como um todo, ordenando em um nível superior o despedaçamento do corpo na realização do prazer dionisíaco. Nem entrega báquica, nem ascetismo cristão - mas os dois entrelaçados: desejo e renúncia, prazer e arrependimento, gozo e culpa. Presença da plenitude subjetiva da liberação sexual póspsicanálise, além de repressões de todos os tipos de um cristão exemplar, fiel e familiar. O poeta se dissolve em Brasil, se despedaça na festa carnavalesca, mas esse despedaçamento e essa dissolução em Brasil são somente parte do mito dionisíaco. Como o deus das estações, o poeta também se recompõe, renovado, elevado pela realização dos sentidos. E mais, o dionisismo faz o poeta renascer com o Brasil incorporado em si. A religiosidade se une ao mito, e ambos unidos especificam o erotismo e a filia do poeta, que se modelam pela experiência brasileira e visam elevar a sua significação, mesmo da perspectiva amorosa. É assim que, ao final do poema, que também é o fim da festa, a realização sensorial é plena: “fadiga de gozar" (v. 310), e aos poucos paira sobre o fim do carnaval uma melancolia... "Peri triste sentou na beira da calçada" (v. 327). O poeta vai retornando a si, recompondo o mundo à sua volta. Em meio ao carnaval, a desolação de uma família pobre, a festa como "pão e circo", um pouco de ironia política ("Tenentes”, "Partido Democrático”). Contudo, a observação fria do mundo à sua volta, que acompanha a sensação de uma libido anestesiada, dá umas pinceladas finas no poema, mas não é seu arremate. Este vai ser o retorno do poeta sobre si mesmo. O contrário da pluralidade inquietante: um torpor relaxante, uma solidão satisfeita em seu isolamento:

\footnotetext{
Lentamente se acalma no país das lembranças

A invasão furiosa das sensações.

O poeta sente-se mais seu.

E puro pelo contacto de si mesmo

Descansa o rosto sobre a mão que escreverá
}

(versos 340-344)

O momento meditativo resulta de um longo processo em que o poeta pôde explodir todas as suas sensações físicas e todas as suas disposições espirituais, e reconstituir-se dionisiacamente em um poeta de sensorialidade e sensualidade brasileiras. A sexualidade ambivalente, o olhar social e o sentimento religioso católico, a linguagem de todas as palavras do Brasil justapostas e simultâneas: uma espécie de "união mágica" entre poeta e Brasil pela via sensorial e intelectual, enfim. Tendo levado a cabo o maior 
número de contatos socioculturais possíveis, e rompendo a mediação de quase todos com sua presença sensorial - não como testemunha ocular, mas como participante sensorial -, o poeta tem um momento de realização plena, em que o sono, mais do que uma bênção, é puro relaxamento, pois a realização anterior já não necessita mais da compensação do sonho: "O poeta dorme sem necessidade de sonhar" (v. 354). O que pacifica a sensibilidade e o intelecto do poeta é a realização, real ou imaginária, não importa, da pluralidade de seus desejos, e a síntese sensorial das diferenças sociais e culturais. Essa mistura de mediação sociocultural e imediação sensorial vai se impor verticalmente na relação do poeta com seus objetos amorosos.

\section{Renúncia}

Em "Paisagem n. ${ }^{\circ}$ 3" (Paulicéia desvairada), o primeiro poema amoroso da obra de Mário de Andrade, sua configuração estética é regida pelo recalque. O poema é sobrecarregado de referências literárias e minúcias psicológicas. O propósito de uma estética arlequinal combina bem uma mistura de desejos e refolhos, de pudor e indiscrição, montando um cenário amoroso mais próximo de uma mascarada, em que as afetações de palavras como "petit-pavê" se alternam com expressões coloquiais de conotação vulgar, como "as rolas da Normal":

\section{Chove?}

Sorri uma garoa cor de cinza,

Muito triste, como um tristemente longo...

A casa Kosmos não tem impermeáveis em liquidação...

Mas neste largo do Arouche

Posso abrir meu guarda-chuva paradoxal,

Este lírico plátano de rendas mar...

Ali em frente... - Mário, põe a máscara!

- Tens razão, minha Loucura, tens razão.

O rei de Tule jogou a taça a mar...

Os homens passam encharcados..

Os reflexos dos vultos curtos

Mancham o petit-pavé...

As rolas da Normal 
Esvoaçam entre os dedos da garoa...

(E si pusesse um verso de Crisfal

No De Profundis?...)

De repente

Um raio de Sol arisco

Risca o chuvisco ao meio.

O assunto amoroso começa na segunda estrofe. O poema, que ao longo da primeira estrofe apresenta um sujeito lírico que observa descompromissadamente a chuva, a cidade e a si próprio, ${ }^{224}$ sofre uma entrada brusca com o "Ali em frente..." que abre a segunda estrofe. A necessidade de "pôr a máscara" ainda não evidencia a questão amorosa, que só entra em cena com a taça do rei de Tule, a qual evoca a "Canção do rei de Tule", um dos famosos lieder amorosos de Goethe. Quem apareceu? Por que pôr a máscara? Que amor é esse que evoca o "rei de Tule"? O fato de sabermos pouco ou quase nada do que está acontecendo nessa segunda estrofe é tão estrutural no poema quanto o que é conhecido pelos versos. Podemos dizer que a expressão amorosa nesse momento é tão mais arrebatadora quanto mais ela se oculta. $\mathrm{O}$ amor no poema, nesse sentido, é configurado no recalque da expressão amorosa, em um pudor indiscreto de quem se encaminha para algo transgressivo. Há na composição dos versos uma série de desvios, como referências literárias e metapoéticas, assim como disfarces que encobrem evocações táteis e eróticas. Essas evocações são elaboradas na terceira e última estrofe pela identificação da chuva com o toque: “dedos da garoa”. A posição de observador interessado do sujeito lírico o investe na posição de voyeur. De certa forma, o voyeurismo do eu lírico se desdobra em um tateamento libidinal das "rolas da Normal". Esse tateamento, possibilitado pelo voyeurismo e pelas associações psicológicas de chuva e toque, pressupõe uma defesa, igualmente psicológica, do eu lírico, a sua máscara: "Mário, põe a máscara". No entanto, o final do poema é uma nova entrada brusca, como o "Ali em frente..." da segunda estrofe. O "raio de Sol arisco" risca não apenas o chuvisco ao meio mas também a sonoridade final, a qual é raspada pelos "i" que se repetem pelos dois últimos versos. Essa entrada final subverte o poema, pois o chuvisco é riscado, como se o poeta parasse de tatear as "rolas da Normal" e recolhesse

\footnotetext{
${ }^{224}$ Para um comentário breve, mas pertinente, da urbanidade do sujeito lírico nesse poema e do equilíbrio estético de imagens e linguagem, ver LAFETÁ, João Luiz. A representação do sujeito lírico na Paulicéia desvairada. A dimensão da noite. São Paulo: Duas Cidades/Editora 34, 2004. p. 370-371.
} 
as mãos com pudor e mesmo a posição de voyeur é desfeita pelo alumbramento do "raio de Sol", com maiúscula, que desfaz a chuva e a máscara. Aquilo que é realmente importante para o sujeito lírico é o que o emudece. Quando o poeta percebe "raio de Sol”, o poema acaba. O leitor apenas entrevê o amor do poeta, pois este interrompe o fluxo lírico justamente no momento em que saberíamos o que o poeta realmente quer na paisagem que descreve. Trata-se de uma renúncia do poeta diante da expressão amorosa, que se deixa ver somente por breves e pequenas frinchas. $O$ elemento de renúncia é, portanto, muito indiscreto, vinculado como está a um recalque mais frívolo, ligado à urbanidade e disponibilidade de um arlequim na Paulicéia. Em momento mais maduro e reflexivo de sua obra poética, a renúncia vai conformar uma situação amorosa mais densa, com um objeto amoroso bem definido e um sujeito lírico que utiliza menos disfarces e expõe com mais precisão e delicadeza as vicissitudes de um amor frustrado ou irrealizável.

Esse amor irrealizável, o amor por uma "rica senhora", é o tema do ciclo de poemas "Tempo de Maria", do livro Remate de Males. A "Maria” em questão é, da perspectiva biográfica, o objeto amoroso mais reconhecível da poesia de Mário de Andrade: trata-se de dona Maria Carolina, filha de dona Olívia Guedes Penteado, casada, e por quem Mário se apaixona já sabendo da impossibilidade de sua realização e da não correspondência de sua amada. Os aspectos externos e biográficos desse amor, que podem ser acompanhados em suas cartas, são menos relevantes e auxiliam pouco, ou quase nada, na compreensão dos poemas do ciclo. Suas referências internas, como o fato de tratar-se de uma mulher comprometida, rica e prestigiada socialmente, são suficientes para compor o quadro de renúncia e amor platônico, com frequentes pulsões incontroladas de agressão e transferência que perpassam os poemas. Essa necessidade de contenção do sujeito amoroso se expressa, também, na escolha das formas poéticas. O poeta dispõe de material poético prefigurado pela tradição, seja pela tradição da formas fixas e da linguagem do cancioneiro popular brasileiro: "Moda do Corajoso", "Lenda das Mulheres de Peito Chato", seja pelas referências às formas herdadas da poesia europeia, como a cantiga de amigo: "Cantiga do Ai”, ou os decassílabos brancos cuja fonte é o Romantismo inglês (e também o brasileiro): “Louvação da Tarde". Além desses, há também a continuação da experiência modernista da associação livre em 
"Amar Sem Ser Amado, Ora Pinhões". ${ }^{225}$ Nos seus demais ciclos de poemas amorosos: "Poemas da Negra", "Poemas da Amiga" e "Girassol da Madrugada" não há uso de formas fixas, pois neles a presença do objeto amoroso e a sua relação com o eu lírico é que estruturam a forma (como veremos posteriormente).

Os poemas que compõem o ciclo "Tempo de Maria" versam principalmente sobre o sofrimento de um amor irrealizável, sobre a força de um amor que arrebata o sujeito lírico e a dor pungente no peito do amante que tem de refreá-la; além disso, os poemas do ciclo são extensas experimentações com os modos de sentir e se expressar do sujeito poético brasileiro. Assim, um trabalho de sensibilidade brasileira e linguagem brasileira se misturam à necessidade de expressão amorosa. O primeiro poema, a "Moda do Corajoso" recupera a tradição mais popular da modinha, mas a insufla com a nobreza do amor elevado. A mescla é notável e interessante, e resulta numa mistura peculiar de Petrarca e Domingos Caldas Barbosa, unidos na linguagem popular brasileira. Desse modo, vem o amor platônico: “O meu corpo encasquetou/De não gostar senão de uma.../Pois, pra não fazer feiúra,/Meu espírito sublima/O fogo devorador" (versos 2226), e o arremate modinheiro: "Faz da paixão uma prima/Faz do desejo um bordão,/E encabulado ponteia/A malvadeza do amor" (versos 27-30). Esses versos finais lembram o masoquismo dengoso de nosso principal autor de modinhas, Domingos Caldas Barbosa, como se pode ler nestes versos: "Eu sei, cruel, que tu gostas,/Sim gostas de me matar;/Morro e por dar-te mais gosto,/Vou morrendo devagar", do poema "Vou Morrendo Devagar". Mário, então, acrescenta ao trabalho de linguagem a recuperação de um traço psicológico, trazendo para seu poema essa fonte árcade mais popular que definiu "de modo explícito os traços afetivos correntemente associados ao brasileiro na psicologia popular: dengue, negaceio, quebranto, derretimento". ${ }^{226} \mathrm{O}$ segundo poema do ciclo, "Amar Sem Ser Amado, Ora Pinhões", está estruturado na associação livre modernista e em detalhadas variações rítmicas e rímicas, como veremos mais adiante. $\mathrm{O}$ terceiro poema, "Cantiga do Ai", recupera a tradição da chamada lírica trovadoresca, compondo uma "cantiga de amigo", com versos paralelísticos rimados e sentimento de ausência. A diferença em relação à tópica tradicional é que nesta a voz lírica feminina lamenta o amante que partiu, e no poema de Mário é a voz lírica masculina do amante

\footnotetext{
225 Os poemas do ciclo Tempo de Maria são: I. Moda do Corajoso; II. Amar Sem Ser Amado, Ora Pinhões; III. Cantiga do Ai; IV. Lenda das Mulheres de Peito Chato; V. Eco e o Descorajado; VI. Louvação da Tarde; VII. Maria.

${ }^{226}$ CANDIDO, Antonio. Formação da literatura brasileira. Belo Horizonte: Itatiaia, 1959. v. I, p. 149.
} 
que parte de uma amada de "olhar frio". A apropriação pessoal da forma tradicional se repete na "lenda" em redondilhas maiores do quarto poema do ciclo, "Lenda das Mulheres de Peito Chato". Aqui, Macunaíma gostou de uma moça bonita e casada, Maria, mas a recusa da moça foi vingada pela mutilação de seus peitos, substituídos por dois cachos de bananeira. Pela lógica da lenda, é essa narrativa que explica por que as amadas são hoje assim, duras e de peito chato. A compensação violenta transfigurada nessa lenda cede o passo ao humor amargo da brincadeira responsorial do quinto poema, "Eco e o Descorajado", em que, feito um oráculo apalhaçado, o eco responde a perguntas fundamentais da vida do poeta com um eco rímico. Esse eco, nas duas primeiras estrofes, rima com o segundo verso da estrofe, e na última estrofe, a mais carregada de humor amargo, rima com o verso imediatamente anterior. ${ }^{227}$ A essas transposições e desvios do amor frustrado por meio de disfarces formais se segue um poema da maior seriedade, de relacionamento muito vago com o ciclo como um todo, “Louvação da Tarde". Esse poema, axial na obra poética de Mário de Andrade e que será analisado em mais detalhe no Capítulo IV desta tese, trata da questão amorosa um tanto de passagem nos versos 69-91, num poema de 165 versos, e seu tratamento corresponde a uma parte do poema, cujo horizonte é mais amplo e contém uma das grandes meditações que constitui o eixo de sínteses da obra poética de Mário. ${ }^{228}$ Por fim, o sétimo poema do ciclo, "Maria" é uma curiosa expressão platônico-realista desse amor frustrado, tingida de fina ironia quanto às prerrogativas sociais e o cotidiano familiar e social da amada.

Essa extensa e variada gama de referenciais, que inclui componentes poéticos, verbais e realísticos, pode ser agrupada e estudada em conjunto da perspectiva da renúncia amorosa, figurada em amor platônico, no contexto da estruturação social brasileira em 1920. Contudo, para que a especificação esteja presente e ancore a reflexão crítica, é aconselhável partir da leitura de um poema e iluminar a partir dele, com as pontes possíveis com outros poemas, as questões conceituais concernentes à renúncia amorosa na poesia de Mário de Andrade e a especificidade brasileira de sua

\footnotetext{
227 Para dar mais visibilidade à descrição do poema, cito a sua primeira estrofe: "Neste lugar solitário/Onde nem canta o sem-fim,/Choro. E um eco me responde/Ao choro que choro em vão./Eco, responda bem certo,/Meu amigos me amarão?.../E o eco me responde: - Sim”.

228 Sobre esse eixo de meditações poéticas, Mário escreve em carta a Drummond, de 24 de agosto de 1944, ao falar de uma imaginada "Meditação sobre o Amazonas": "Seria assim um coroamento de meus caminhos, como o 'Noturno de Belo Horizonte', como a 'Louvação da tarde', como os 'Poemas da amiga' são também fins de caminho" (SANTIAGO, Silviano (Org.). Carlos \& Mário. Correspondência de Carlos Drummond de Andrade e Mário de Andrade, cit., p. 526).
} 
figuração platônica. Dentre os poemas do ciclo, pela complexidade de sua construção e originalidade de sua solução, escolho "Amar Sem Ser Amado, Ora Pinhões" como proposta de análise.

Nesse poema, o sujeito lírico imprime na linguagem uma variada gama de movimentos psicológicos, rítmicos e rímicos, fazendo o poema acompanhar cada minúcia do estado amoroso do poeta, em que entram desvios, substituições, transferências - um borboletear do $e u$ por um mundo mais frívolo, que convive com o pesar da frustração amorosa. Aliás, a frustração amorosa propriamente dita ocupa um pouco menos da segunda metade do poema. Todo o poema até então é uma sequência de associações livres de um poeta que pega um bonde num fim de tarde. Até o verso 85 , acompanhamos o "poeta de viação barata" (verso 4), que retoma o verso "Eu sou o poeta das viagens de bonde", do seu "Poema Abúlico", publicado no número duplo 8/9 de Klaxon (dezembro de 1922/janeiro de 1923) e não recolhido em livro. ${ }^{229}$ Nesse momento, acompanhamos, pela rapidez das associações de imagens, um poema modernista ortodoxo, próximo, em termos imagéticos, dos poemas hiperacelerados de Luís Aranha. ${ }^{230}$ A essa disposição corresponde a multiplicação do eu:

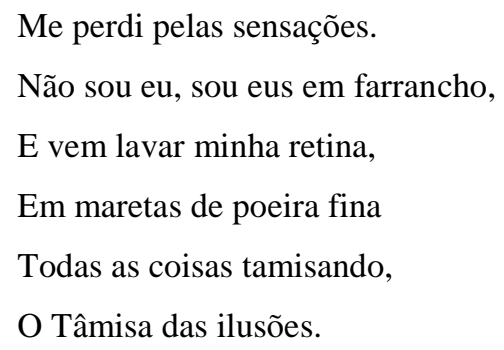

Essa multiplicação do eu, ou dos eus, pela cidade, transfigurando, absorvendo e esparramando por ela as sensações é rompida pela declaração amorosa do poeta por uma mulher só:

\footnotetext{
${ }^{229}$ BRITO, Mário da Silva (Org.). KLAXON - mensário de arte moderna. Edição fac-similar (19221923). São Paulo: Livraria Martins, n. 8/9, p. 13-15, dez./jan., 1972. Há ainda algumas passagens desse "Poema Abúlico" em “Amar Sem Ser Amado, Ora Pinhões", como essas passagens do poema de Klaxon: "Mário, paga os 200 réis!" (verso 5), recuperado quase inteiro no verso 5 de "Amar Sem Ser Amado...", e “As maretas das calçadas vêm brincar a meus pés" (verso 6) imagem modificada em "E vem lavar minha retina/Maretas de poeira fina" (versos 27-28 de "Amar Sem Ser Amado...”).

${ }^{230}$ Sobre Luís Aranha, ver ANDRADE, Mário de. Luís Aranha ou a Poesia Preparatoriana. Aspectos da literatura brasileira. Belo Horizonte: Itatiaia, 2002. Ver também Capítulo II desta tese, p. 92-94.
} 
Te amo!... Que bonita que ela é!...

Trago comigo o cheiro dela,

Só penso nela!... Infelizmente

O meu caso não tem futuro,

Ai, Maria do perfil duro,

Ai, Maria sempre presente!...

(versos 85-90)

“Só penso nela!...”. Não parecia, pois entre as multiplicações do poeta, está um amorpaixão repentino pela moça que senta à frente dele no bonde, e a conclusão: "Porque enfim é amante de poeta/Toda e qualquer mulher que passe" (versos 70-71). Como explicar a relação da sensualidade incontida do poeta modernista com a unificação do amor em torno de uma mulher só, única e inatingível? A causa psicológica não será difícil de imaginar, pois, recusando-se inicialmente a enfrentar o amor frustrado por Maria, o poeta recorre àqueles desvios, substituições e transferências, tanto mais acelerados e fugazes quanto maior é a presença latente da inesquecível Maria. Assim, o borboletear por sensações efêmeras não é um procedimento autossuficiente no poema, mas, sim, uma consequência do sentimento tão pouco modernista àquela altura, exposto na estrofe citada. Mas se a causa psicológica não é difícil de adivinhar, como o poeta lida com essa dualidade de posturas - modernista e platônica - na estruturação de um poema que, de saída, se coloca como radicalmente modernista? Uma primeira resposta a essa pergunta reside na estruturação sonora do poema. Se no plano das imagens e sensações reina uma associação livre acelerada, a estruturação rítmica e rímica é finamente disciplinada. ${ }^{231} \mathrm{O}$ poema é construído em versos octossílabos dispostos em estrofes de seis versos. ${ }^{232} \mathrm{O}$ ritmo do octossílabo usado pelo poema é extremamente variado, mantendo algumas constantes rítmicas ao longo do poema, como os acentos 35-8, 2-4-8, 1-4-8, 3-6-8, 2-5-8 e 2-6-8, mais uma dezena de fórmulas rítmicas que aparecem uma ou duas vezes. ${ }^{233} \mathrm{E}$ a mesma fórmula rítmica não se repete por mais de dois versos em sequência. Dentro dessa enorme variabilidade rítmica, ressalta-se a

\footnotetext{
${ }^{231}$ As "leis proclamadas pela estética da nova poesia", que Mário expõe em A Escrava que não é Isaura [1922], podem ser sintetizadas em dois procedimentos básicos: 1. Palavra em liberdade (verso livre, rima livre, vitória do dicionário); e 2. Associação livre (substituição da ordem intelectual pela ordem subconsciente, rapidez e síntese, polifonismo, simultaneidade). $O$ poeta opera radicalmente com o segundo item, bem como disciplina radicalmente o primeiro (ANDRADE, Mário de A escrava que não é Isaura. Obra imatura. Belo Horizonte: Itatiaia, 1980. p. 225-226).

${ }^{232}$ Com as seguintes exceções: a estrofe 16 tem 7 versos, e os versos 46, 67 e 113 são eneassílabos.

${ }^{233}$ Sigo as principais sílabas tônicas "fortes", deixando de lado as que Said Ali chama de "semiforte" (ALI, Manoel Said. Versificação portuguesa. São Paulo: Edusp, 1999. p. 35).
} 
regularidade da alternância de ritmos pares e ímpares, disciplinando a liberdade da expressão. $\mathrm{O}$ esquema estrófico não é menos rico. Os seus seis versos alternam rimas consoantes e toantes, que exploram uma grande diversidade combinatória. Assim, em 23 estrofes, a combinação rímica mais presente é a ABCCBA, que ocorre 5 vezes, seguindo $\mathrm{ABCCB}$ (toante)A, que ocorre 3 vezes, e mais uma combinação que se repete: $\mathrm{ABCCB}$ (toante)C(toante). Além dessas combinações, há mais de dez que aparecem somente uma vez. Desse modo, há equivalência entre excesso de movimentos e certa disciplina interior tanto na relação entre associação livre modernista e amor platônico quanto na relação entre liberdade no uso das palavras e sua rigorosa ordenação rítmicorímica. $\mathrm{Na}$ forma do amor como na forma da expressão, há uma dualidade entre a mais intransigente liberdade e a mais necessária disciplina.

Em seu contexto brasileiro, essa duplicidade de disposições do sujeito lírico ao longo do poema corresponde, certamente, a uma dilaceração entre o anseio de realização individual do sujeito moderno, que confia em suas potencialidades libertárias, e a respeitabilidade moral e de conotação cívica e exemplar, de quem vive de acordo com limites individuais e sociais previamente estabelecidos: a vergonha do adultério, o respeito pela negação da amada:

\footnotetext{
Tudo isso há-de passar, Maria,

Durma em sossego. O meu respeito

Sempre há-de respeitar você.

Eu não aguento mais meu peito!

Mas jamais não aceitaria

Arranjos como o de Musset
}

(versos 116-121)

A evocação do relacionamento adúltero de Musset (palavra que cria uma rima virtuosística e um tanto frívola com "você") com George Sand mostra o quanto o poeta rejeita as aventuras amorosas transgressivas, e que ele terá um amor sublimado, ao menos até encontrar outra "paixonite". A oscilação entre disposições elevadas e mesquinhas lembra ainda a mascarada de "Paisagem n. ${ }^{\circ}$ ", e nos alerta para a problematicidade ou a incompletude do seu amor platônico. ${ }^{234}$ Nas notas às Poesias

\footnotetext{
${ }^{234}$ Uma descrição em prosa que já mistura disposições elevadas e traços humorísticos na descrição do amor platônico lemos em "O mal não é a gente amar... O mal é a gente vestir a pessoa amada com um despropósito de atributos divinos, que chegam a triplicar às vezes o volume do amor, o que se dá? Uma pessoa natural é fácil a gente substituir por outra natural também, a questão de sair uma e entrar outras...
} 
completas, lemos que os poemas do Tempo de Maria são resultados de um projeto abandonado de escrever um longo Ciclo de Maria, "nos moldes da Vita Nuova de Dante". ${ }^{235}$ O modelo de amor platônico em questão reata, por conseguinte, com sua origem medieval, que, começando com a codificação do "amor cortês" provençal, vai ganhar estatuto filosófico e totalizante na poesia de Dante e Petrarca, o qual dará início à lírica amorosa do Renascimento. ${ }^{236}$ A relação entre renúncia e amor platônico, como realização plena e espiritual do $e u$, não será levada a cabo por Mário de Andrade, o que parece apontar, para além de um possível esgotamento biográfico do amor de Mário por dona Maria Carolina, para a insuficiência da lírica amorosa platônica como forma válida no momento histórico em questão ou, complementar a isso, para a impossibilidade de herdar e atualizar a melhor e mais longa tradição da lírica amorosa europeia. Essa impossibilidade gera poemas amorosos um tanto híbridos, que misturam as compensações espirituais da renúncia amorosa a um realismo afetivo mais cotidiano, acompanhando as variações psicológicas do eu lírico entre disposições elevadas e prosaicas. Salvo engano, um dos motivos desse hibridismo amoroso, ou de seu platonismo incompleto, ocorre em função da má individuação do eu, da problematicidade e da má-formação da subjetividade lírica na poesia brasileira, pois a capacidade de renúncia e espiritualização do amor está em relação direta com a capacidade de diferenciação social do $e u$ e de sua separação do fluxo da vida social. O amor platônico é a primeira grande mediação entre o eu lírico e a vida social. O eu lírico se forma quando, por meio do amor não realizado, volta-se sobre si próprio e abre em si mesmo um espaço de interioridade, no qual todas as coisas do mundo podem habitar filtradas pela disposição amorosa do $e u$. Se, pela mediação do amor platônico, o eu lírico cria um espaço de interioridade em que cabe o mundo todo filtrado pelo amor, igualmente a visão de mundo desse $e u$ vai ser subjetivada:

Tant ai mo cor ple de joya,

tot me desnatura.

Porém, a que sai do nosso peito é amor que sofre de gigantismo idealista, e não se acha outra de tanta gordura pra botar logo no lugar. Por isso fica um vazio doendo, doendo...” (ANDRADE, Mário de. Jaburu Malandro [1924]. Contos de Belazarte. São Paulo: Círculo do Livro, s/d. p. 36).

235 ANDRADE, Mário de. Poesias completas. Edição crítica de Diléa Zanotto Manfio. Belo Horizonte: Itatiaia; São Paulo: Edusp, 1987. p. 509.

${ }^{236}$ Sobre o Dante e Petrarca na história da literatura europeia, ver CARPEAUX, Otto Maria. O Trecento e Renascença Internacional. História da literatura ocidental. Rio de Janeiro: Edições O Cruzeiro, 1961. v. I-A. 
"Trago o coração tão cheio de alegria, que tudo se me transfigura". Assim começa uma canção do trovador provençal Bernatz de Ventadorn, ${ }^{237}$ em que os efeitos do amor sobre o eu transforma a realidade apreendida pelo sujeito, que, por sua vez, é capaz de remontar o mundo todo pela mediação subjetiva de seu amor. Pelo poder espiritualizante do amor platônico, o eu pode descobrir sua interioridade, conhecer-se e mesmo transcender-se, como pode igualmente ver o mundo com olhos próprios, pois, diferenciado dele, é capaz de remontar o mundo pelo ponto de vista do $e u$.

A mulher amada também transcende a contingência de sua existência terrena e, por seus encantos morais e pela espiritualização de sua beleza física, é elevada ao estatuto de nume tutelar ou de guia do poeta para elevar-se às mais altas esferas, como foi realizado por Dante em relação a Beatriz. Contudo, a Maria dos poemas de Mário de Andrade tem um excesso de presença contingente. As atitudes da amada de "perfil duro" e de "olhar frio" não levam o poeta ao percurso reflexivo do amor platônico, ativo mesmo quando se trata de manifestações de recusa da amada. As atitudes da mulher amada provocam no poeta atitudes igualmente imediatas: substituições e desvios psicológicos, declaração de respeito, impulsos violentos (em "Lenda das Mulheres de Peito Chato") e mesmo uma fina ironização no poema VII, denominado "Maria". Aqui sobrepõe um idealizado verso platônico a um verso realista:

Passa pura neste mundo,

Sendo chique e sendo rica

(versos 1-2)

Esse segundo verso aponta para o outro elemento que vem se entroncar no amor platônico para constituir a forma híbrida dos poemas em questão: o realismo do desejo erótico modernista. Mário já notara essa passagem do amor em desejo de gozar em sua poética modernista A escrava que não é Isaura: "Aliás confessemos: a capacidade de amar dos poetas modernistas enfraqueceu singularmente" e mais adiante, "A capacidade de gosar aumentou todavia". ${ }^{238} \mathrm{Na}$ disposição amorosa modernista, antípoda e antagônica do amor platônico, o desejo não reconhece barreiras entre si e sua realização, e todas as mediações podem ser transgredidas em nome da confiança do $e u$ em seu agir sobre a realidade contingente que o circunda e mesmo em seu poder de

\footnotetext{
${ }^{237}$ SPINA, Segismundo. A lírica trovadoresca. São Paulo: Edusp, 1996. p. 140 e 142.

${ }^{238}$ ANDRANDE, Mário de. A escrava que não é Isaura, cit., p. 213 e 214. Mantive a ortografia do texto original.
} 
modificá-la. A subjetividade modernista não se forma pela separação e diferenciação do real. Ao contrário, dado o avanço da colonização pela vida social moderna de todas as esferas da vida, mesmo da interioridade da vida subjetiva, a disposição de vanguarda, modernista, lança os últimos trunfos da subjetividade em uma participação antagônica na realidade da vida social. Sua realização ocorre em uma participação crítica no real contingente, em um verdadeiro engajamento formal do sujeito lírico. Contudo, amor platônico e amor modernista se conjugam em "Tempo de Maria" sem se reconhecerem e se confrontarem, antes eles se temem e se evitam, embora se persigam o tempo todo, configurando um tipo de disposição amorosa que mimetiza uma "fuga" musical, em que uma melodia "persegue" a outra, sem que a duas nunca se encontrem.

O que diferencia e singulariza esse amor no conjunto da poesia amorosa de Mário de Andrade é a posição social elevada da mulher amada, principalmente a posição social acima do poeta. É nos embates de um sujeito lírico que se sente em parte individualista e moderno, em parte vassalo que se configura, pela minha perspectiva, a incompletude das formas da lírica que o poeta utiliza. $\mathrm{O}$ amor platônico, principalmente em sua origem de amor cortês, pressupõe uma separação social de "casta" ou uma impossibilidade real de realização amorosa, enquanto o amor modernista só concebe a sua não realização como angústia e dilaceração, pois não reconhece mais fronteiras intersubjetivas que não sejam as da vontade dos sujeitos envolvidos. Ora, não é a primeira vez na história da lírica brasileira que o amor do poeta de condição social inferior, agravada pela condição racial tida como inferior, é expresso poeticamente em uma forma dilacerada entre a adoração da mulher inatingível e o sentimento de ver humilhadas as suas prerrogativas de sujeito moderno. A primeira aparição dessa conjunção formal em nossa lírica foi notada por Roberto Schwarz a propósito do poema de Gonçalves Dias, "Ainda uma vez - Adeus!": "tão romântico pelo movimento e tão fiel às contingências civis na experiência dos amorosos". ${ }^{239}$ Um segundo momento que

\footnotetext{
${ }^{239}$ Esse comentário de Roberto Schwarz em nota vem a propósito do envolvimento amoroso de Helena e Estácio, no romance Helena, de Machado de Assis, sobre o qual diz o crítico: “Assim, a ideologia decente e familiar, amiga de sacrifícios e estrangeira a todo romantismo, corre paralela a uma nostalgia subterrânea de satisfação individual completa, para além de quaisquer limitações, isto sem que os absolutos do romantismo sejam evocados explicitamente. Embora não seja desmentido nem posto em questão, o decoro paternalista nesta companhia adquire uma componente sensível de renúncia. À ideia cristamente positiva de sacrifício se acrescentam conotações negativas, de sufocamento e frustração da pessoa, em que está presente o individualismo romântico, mas refundido e dando expressão ao conflito local" (SCHWARZ, Roberto. Ao vencedor as batatas. São Paulo: Duas Cidades/Editora 34, 2000. p. 149). O leitor dirá se forço a nota ao trocar os termos "romantismo" por "modernismo", com sua consequente intensificação da demanda de liberdade individual, e ver a permanência desse mesmo conflito na poesia amorosa de Mário de Andrade em "Tempo de Maria". Há na série de poemas
} 
pude descobrir, de valor poético muito inferior, foi o de Tobias Barreto. A posição desse poeta sergipano na Faculdade de Direito do Recife na segunda metade do século XIX tem muita semelhança com a posição de Mário na São Paulo da década de 1920. Pequeno burguês, mestiço, de talento extraordinário e temperamento arrebatado, foi estudante de brilho e, como professor daquela faculdade, se engajou pela modernização do pensamento brasileiro, destacando-se pelo seu talento e temperamento combativo. Empenhou-se na difusão do Cientificismo e da língua alemã no Brasil, combateu o Poder Moderador no plano político e o acanhamento da inteligência brasileira no plano intelectual. Discípulos entusiasmados pelo mestre foram Sílvio Romero, Gilberto Amado e Graça Aranha. O que vem ao caso, nessa exposição, é que esse homem arrebatado e combativo, mas de condição social inferior, viveu um romance com dona Leocádia Siqueira de Albuquerque, oriunda da fina flor da aristocracia pernambucana. O resultado foi a repetição, com cerca de 35 anos de distância, do caso de Gonçalves Dias com dona Ana Amélia Ferreira do Vale, de boa cepa maranhense, cuja família negou ao poeta a mão da moça em casamento, embora se tratasse de um amor correspondido. Da rememoração madura desse acontecimento à vista da amada em Lisboa decorre o poema “Ainda uma vez - Adeus!". Os detalhes do romance de Tobias Barreto e os poemas que o pontuam podem ser acompanhados na História da literatura brasileira de Sílvio Romero. ${ }^{240}$ Sem que nenhum poema esteja acima do medíocre, é notável o movimento subjetivo que os conforma, principalmente os poemas finais desse ciclo amoroso: “A nota capital nas [suas] últimas poesias [...] é a do amor que faz sacrifício de si mesmo, procurando ocultar-se, chegando até, em certos passos, a protestar a sua inexistência. É singular este misto de orgulho e humilhação, esta rara

dedicados a Maria, alguns que o poeta não publicou. Em um deles, chamado "Burradas n. 1", há um desenvolvimento desse tema. Repetindo um verso de "Amar Sem Ser Amado, Ora Pinhões", o poeta prossegue descrevendo o efeito que esse amor realizado teria sobre o destino dos amorosos. Cito do longo poema apenas as quatro primeiras estrofes, a título de exemplo: "Porém nunca eu aceitaria/Arranjos como o de Musset...//Eu pisaria sobre minha mãe e minha irmã desonradas,/Como ela passaria junto dos filhos/Sem mesmo se rir pra esses desconhecidos chorando...//Olharíamos conscientes a raiva dos homens,/O desprezo invejoso dos homens não nos atingiria mais,/E vivendo junto de tudo, na solidão mais formidável,/Com cinismo guaçu, como cinismo de heroísmo,/Nós realizaríamos o amor//Nos insultariam com todos os aviltamentos menos um,/Ninguém nos chamaria de covardes,/Porque seríamos os seres mais desinfelizes que a vida criou,/Porém nós realizaríamos o amor" - enviado a Manuel Bandeira em carta de 2 de maio de 1931 (MORAES, Marco Antônio (Org.). Correspondência Mário de Andrade \& Manuel Bandeira. São Paulo: Edusp/IEB, 2001. p. 503) e recolhido por Oneyda Alvarenga na seção Poemas "Malditos" (ALVARENGA, Oneyda. Mário de Andrade, um pouco. Rio de Janeiro: José Olympio, 1974. p. 127-128).

${ }^{240}$ ROMERO, Sílvio. História da literatura brasileira. Rio de Janeiro: José Olympio, 1960. t. IV, p. 1223-1.241. 
mescla de devotamento e receio, de esquivança e atração". ${ }^{241}$ Surpreende a semelhança dessas disposições de sujeitos líricos tão diferentes, embora com qualidade literária bastante diversa. A esse rol pode ser acrescentado Mário de Andrade. A reposição social do atraso, na medida mesma em que a sociedade brasileira avança, não gera conflitos e desconcertos somente em seus aspectos externos, da estrutura de classes ou do malassentamento nacional da história das ideias. Também os dilemas subjetivos são repostos, e mesmo o amor, o que é por excelência mais íntimo no sujeito, é atravessado verticalmente pelo processo histórico, impedindo tanto a realização moderna do amor, fruto do desejo e da vontade intersubjetivos, que só diz respeito a indivíduos autônomos, quanto impede a separação e a diferenciação pelo amor platônico, dado o teor de vexame de um sujeito dotado formalmente de prerrogativas modernas, um eu lírico, no caso, afirmar uma posição de vassalo, pois essa configuração formal poderia apontar para uma condição social de vassalagem real, visto que, com frequência, uma estrutura social de "casta" se mostra ditando as normas da vida social brasileira, o que só poderia ser tomado como opróbrio e autoirrisão.

Contudo, para finalizar a análise, será necessário notar a ousadia formal que Mário acrescenta a esse conflito amoroso estrutural da história da poesia brasileira. Mário de Andrade como que se defende da inferioridade social em relação à mulher amada por certa ostentação de virtuosidade poética, dispondo de formas da tradição literária e popular portuguesas e brasileiras. A isso acrescentou as pesquisas de linguagem e psicologia brasileiras que entroncam em seu "pragmatismo nacionalista" iniciado por volta de 1924 (o começo do Ciclo de Maria é de 1925). Com isso, Mário parece querer dizer que, se a amada não é uma mulher qualquer, que se possa possuir sem prestar contas, tampouco ele é um poeta qualquer, que possa ser esnobado sem dar revide. Nesse quadro, a pureza e a elevação do amor platônico se chocam com a irreverência modernista, criando uma mescla de irritabilidade e ternura que pode ser lida nas três últimas estrofes de "Amar Sem Ser Amado, Ora Pinhões". O poeta já declarara seu respeito à amada, o que significa que não iria cortejá-la diretamente, e escreve:

\footnotetext{
Durma sem medo, sossegada.

Você não vai pra sala grande,

Tem sala à parte no meu harém.

Vista o pijama de meus olhos,
}

${ }^{241}$ ROMERO, Sílvio. História da literatura brasileira, cit., p. 1.235. 
E descanse sobre o meu sonho

Que nunca fez mal a ninguém.

(versos 122-127)

Os primeiros três versos compensam a recusa amorosa com uma blague, rebaixando a amada a participar de um "harém". Afinal, ser uma mulher única e especial em um harém não é o ideal mais genuíno de um amor platônico, antes seria distinção atribuída por um sultão ou imperador chinês. No entanto, da blague saímos para entrar em imagens de genuína ternura, com a contemplação cheia de doçura do "pijama dos olhos", o sonho acolhedor e inofensivo. A estrofe seguinte desenvolve o mesmo assunto:

Eu velarei a corajosa

Dormindo sobre a dinamite...

Fumos... Assombrações... Não te

Largo mais, Iara do Tietê!...

Ao menos até que fareje

Alguma paixonite nova...

(versos 128-133)

O desejo erótico desperta do sonho inofensivo, e a amada passa a dormir sobre a dinamite. A tensão de erotismo e renúncia se intensifica, gerando "fumos" e "assombrações". E não apenas imagens intensas mas também o ritmo - no verso "Fumos... Assombrações..." -, que evoca o verso harmônico de Paulicéia desvairada. As consequências da renúncia são expostas inicialmente em metáforas eróticopsicológicas: no fogo apagado e nas alucinações. Mas ela também se desenvolve nos versos seguintes, em que o amor elevado e infinito pela "Iara do Tietê" é seguido por uma irrisória referência a uma "paixonite" que a sucederia. Novamente, blagues e ternura contida se alternam no desenvolvimento final do poema, até chegar ao momento de sua conclusão no último verso:

É o fim. Lá fora dormirá

Paulicéia. Paz. Quase informe,

Ela dorme, dorme sorrindo, 
Enquanto gemo o verso lindo

Com que as índias parecis dormem

Uirô, mococê ce-macá...

(versos 134-139)

Continuando a estrofe anterior, o poeta ainda está velando o sono da amada. Como se avançássemos noite adentro, o mundo externo se acalmou, e a amada dorme profundamente e satisfeita. $\mathrm{O}$ poeta, entretanto, não renova o contraponto ternurablague, que poderia ser infinito, mas encaminha uma síntese de peculiar originalidade. O poema termina com o sofrimento do eu lírico e a indiferença da amada sintetizados em um acalanto pareci. Mário transpõe o verso de acalanto em suas palavras originais: "Uirô, mococê ce-macá...", o que confere ao verso um redobro de sua função rítmicomelódica, de sua estrutura fônica. Não precisamos saber o significado das palavras do verso para sentir seu ritmo balouçante e pendular da oitava de acentuação 2-3-3, marcado por três vogais diferentes em palavras oxítonas "ô", "ê" e "á”, com o apoio sonoro de transição "ce" entre as duas últimas vogais. A perfeita adequação rítmica desse verso pareci aos versos octossílabos do poema faz pensar se este último verso foi um achado perfeito para encerrar o poema ou se ele foi uma sugestão inicial de que todo o ritmo do poema se desdobra. Em todo caso, o importante é a natureza dessa síntese final do poema. A impossibilidade de conciliação de amor platônico com amor modernista acaba por encontrar uma solução em um verso que é, para o leitor comum, ininteligível, gerando um tipo de acalanto de sonoridade pura, que a força de ser repetido em sua incompreensibilidade e estranheza, tem por finalidade gerar uma semiconsciência dormente, espécie de transe hipnótico. Nesse sentido, Mário termina seu poema com um acalanto anestésico, em que se unem um máximo de elevado sofrimento e devoção amorosa e uma indiferença por anestesia, acrescido de irreverência estética modernista. Novamente, Mário de Andrade ativa seu dionisismo, resolvendo um conflito que atingira um ponto extremo pela embriaguez musical, uma modalidade de transe hipnótico feito da "dança de palavras". Essa solução poética dionisíaca, nascida da disposição profunda da psicologia de Mário e da impossibilidade de realização formal da poesia de amor frustrado e elevado no Brasil de então, surge de uma proposta inicialmente contrária a si. Esse verso final é fruto das pesquisas brasileiras de Mário, especificamente da leitura de Rondônia, de Edgar Roquette-Pinto, 
obra na qual se encontra o acalanto pareci, que significa "Menina, dorme na rede". ${ }^{242}$ Com isso, Mário dispunha as mais detalhadas pesquisas sobre folclore local de modo a atuar com potencial imprevisto na composição da mais elevada expressão da lírica amorosa que a poesia ocidental conhece, dando feição nova e original a uma tensão estrutural e de longa duração na história da poesia brasileira.

Nesse sentido, o destino das formas literárias na poesia brasileira se relaciona profundamente com o processo social brasileiro. O conflito entre o sujeito moderno e a estrutura semicolonial paternalista encontra um ponto privilegiado nas relações amorosas entre homens de condição social inferior e mulheres de origem aristocrática, a que se pode somar o agravante racial, de notável relevância na vida amorosa de nossas classes mais elevadas. Assim, o ciclo de poemas "Tempo de Maria" atualiza de modo original uma questão social e literária de longa data na história brasileira, o que baliza o alcance da expressão poética de Mário nesse campo, ao mesmo tempo em que expõe seus limites. Os outros ciclos de poemas amorosos de Mário expressam diferenças que, em sua poesia, podem ser superadas pela disposição amorosa, e, ao contrário dos poemas do "Tempo de Maria", inovam radicalmente na natureza das disposições amorosas e nas possibilidades do sujeito lírico.

\section{Amor Realizado}

Sobre as relações amorosas entre homem branco e mulher negra na sociedade patriarcal brasileira, afirma Gilberto Freyre, contrariando um lugar-comum da ideologia escravista: "Superexcitados sexuais foram antes esses senhores que as suas negras ou mulatas passivas". ${ }^{243}$ Uma excitação mais complexa, controlada e correspondida percorre os "Poemas da Negra", de Mário de Andrade. "Não sei por que espírito antigo/Ficamos assim impossíveis...", com esses versos se iniciam esses poemas de delicados impossíveis, de entrelaçamento focado em close-up e vastas dissoluções na paisagem pernambucana. Esse ciclo de poemas, ao lado dos "Poemas da Amiga", é resultado da depuração poética operada por Mário de Andrade no fim da década de 1920, quando a brasilidade programática se torna uma naturalidade lírica, no sentimento

\footnotetext{
${ }^{242}$ ROQUETTE-PINTO, Edgar. Rondônia. São Paulo: Companhia Editora Nacional, 1975. [1 ${ }^{\text {a }}$ Edição de 1917]. p. 92.

${ }^{243}$ FREYRE, Gilberto. Casa-grande \& senzala: introdução à história da sociedade patriarcal no Brasil. Rio de Janeiro: Record, 2000. p. 425.
} 
e na linguagem. ${ }^{244}$ Contudo, o momento biográfico de Mário de Andrade que o levou a compor esses poemas é um dos mais delicados de sua vida literária. "Poemas da Negra" datam de $1929^{245}$ e são publicados em Remate de Males (1930). Desde 1927, porém, a posição de Mário no Modernismo brasileiro começa a ser abalada. Publicando a primeira série dos seus Estudos (1927), Tristão de Ataíde, que figurava então como uma espécie de crítico oficial do Modernismo, faz uma divisão redutora do movimento em duas correntes, os seguidores de Graça Aranha, no Rio de Janeiro, e os primitivistas de São Paulo. Nessa divisão, Mário de Andrade figurava em papel relativamente secundário em um primitivismo cujas diretrizes estavam na obra de Oswald de Andrade. ${ }^{246}$ Em 1928, a revista Festa surge no Rio de Janeiro com uma plataforma ortodoxamente espiritualista e buscava se afirmar pela desautorização das bases paulistas do Modernismo (seus integrantes, Tasso da Silveira à frente, consideravam o Modernismo genuíno uma linha direta entre o simbolismo brasileiro e a obra deles mesmos) e pela desvalorização sistemática do "grupo" paulista. Por fim, relativamente contemporâneo à elaboração dos "Poemas da Negra" é o ataque pessoal sofrido por Mário na Revista de Antropofagia, de Oswald de Andrade, em cuja edição de 24 de abril de 1929, por exemplo, é alvo de um dos ataques mais difamatórios. Além disso e das más avaliações de sua obra, a situação é agravada pelo fato de o Modernismo em 1929 estar dividido em grupos de feição bastante sectária: Antropofagia, espiritualistas de Festa, católicos de Jackson Figueiredo na revista A Ordem (Tristão de Ataíde, por exemplo) e grupo da Anta. Diante desse quadro, a perspectiva de uma brasilidade universal e fraterna, de base unanimista e de elaboração coletiva não tem mais lugar. Seja do ponto de vista pessoal, seja do ponto de vista do sentido do Modernismo à época, Mário estava numa posição de isolamento. No entanto, é da reflexão sobre sua posição, ou melhor, da atenção à sua sensibilidade nesse momento que deriva o estado

\footnotetext{
${ }^{244}$ Manuel Bandeira não se cansou de elogiar os "Poemas da Negra" e os "Poemas da Amiga" como pontos altos da poesia de Mário de Andrade. Ver BANDEIRA, Manuel. Mário de Andrade [1931]. Crônicas da província do Brasil. São Paulo: Cosac \& Naify, 2007; BANDEIRA, Manuel. Mário de Andrade e a questão da língua. De poetas e poesia. Rio de Janeiro: Livraria São José, 1957; BANDEIRA, Manuel. Meu Amigo Mário de Andrade [1943/1960]. Andorinha, andorinha. Rio de Janeiro: José Olympio, 1983.

${ }^{245}$ Em carta de 11 de maio de 1929, Mário escreve a Bandeira: "Vão aqui por exemplo os 'Poemas da Negra', feitos recentíssimamente, amostra de minha poesia atual" (MORAES, Marco Antônio (Org.). Correspondência Mário de Andrade \& Manuel Bandeira, cit., p. 416).

${ }^{246} \mathrm{O}$ texto em questão é: ATHAYDE, Tristão de. Tendências. Estudos. $1^{a}$ Série. Rio de Janeiro: A Ordem, 1927 [ $2^{\mathrm{a}}$ edição de 1929]. Mário recusa essa identificação em carta a Tristão de Ataíde de 23 de dezembro de 1927. FERNANDES, Lygia. 71 Cartas de Mário de Andrade. Rio de Janeiro: Livraria São José, s/d. p. 21.
} 
de espírito dos "Poemas da Negra" e "Poemas da Amiga", em que a subjetividade lírica se expressa no tema amoroso. Manuel Bandeira, resenhando Remate de Males, escreve: “Os 'Poemas da negra' e os 'da amiga' parecem vir de um isolamento enorme, mas de um isolamento em que não se pode falar nem de tristeza nem de alegria. Será de indiferença?". ${ }^{247}$ Não será nos termos da "indiferença” que o próprio Mário colocará a questão em carta ao mesmo Manuel Bandeira, mas no da "invisibilidade": "Estou atingindo, Manu, acho que o cume da minha invisibilidade. [...] Dessa orientação os 'Poemas da negra' são o que de mais perfeito e legítimo fiz até agora". ${ }^{248}$ Como expressão dessa invisibilidade, Mário fala de seu "pudor de falar em imagens" e conclui: "Isso talvez venha da meia solidão que me impus e naturalmente é muito reflexiva". ${ }^{249}$ Ainda sobre a relação entre isolamento, invisibilidade e expressão poética, temos esse comentário de Mário: "Mas o que há em mim agora e me dirige a poesia, isto é a parte mais íntima da criação é isso: pudor. E esse pudor é que deu a norma de expressão dos meus versos mais atuais, falar por imagens, falar vago que não faça muito ruído, que não fira demais". ${ }^{250}$ Ainda antes de voltarmos aos versos propriamente ditos dos "Poemas da Negra", devemos notar que essa dialética de história da vida literária, estado de espírito e situação da sensibilidade abre outra vertente da "constância dionisíaca" da poesia de Mário de Andrade. Do dionisismo da embriaguez em "Carnaval Carioca" e do dionisismo do transe hipnótico de "Amar Sem Ser Amado, Ora Pinhões", passamos agora a uma espécie de dionisismo de consolação. Assim fala Nietzsche da dinâmica própria do dionisíaco:

O êxtase do estado dionisíaco, com sua aniquilação das usuais barreiras e limites da existência, contém, enquanto dura, um elemento letárgico no qual imerge toda vivência pessoal do passado. Assim se separam um do outro, através desse abismo do esquecimento, o mundo da realidade cotidiana e o da dionisíaca. Mas tão logo a realidade cotidiana torna a ingressar na consciência, ela é sentida com náusea; uma disposição ascética, negadora da vontade, é o fruto de tais estados [grifo inicial do original, último meu]. ${ }^{251}$

\footnotetext{
${ }^{247}$ BANDEIRA, Manuel. Mário de Andrade [1931], cit., p. 136.

${ }^{248}$ MORAES, Marco Antônio (Org.). Correspondência Mário de Andrade \& Manuel Bandeira, cit., p. 427-8.

${ }^{249}$ MORAES, Marco Antônio (Org.). Correspondência Mário de Andrade \& Manuel Bandeira, cit., p. 482-483.

${ }^{250}$ MORAES, Marco Antônio (Org.). Correspondência Mário de Andrade \& Manuel Bandeira, cit., p. 483.

${ }^{251}$ NIETZSCHE, Friedrich. O nascimento da tragédia ou helenismo e pessimismo. São Paulo: Companhia das Letras, 2007. p. 52-53.
} 
Dada a devida adequação da circunstância entre o dionisíaco da filosofia de Nietzsche e o dionisíaco do "nacionalismo pragmático" de Mário de Andrade, há nas circunstâncias histórico-literárias ora descritas uma espécie de retorno do estado dionisíaco do poeta às realidades comezinhas da disputa de grupos pelo poder literário e um tipo de egomaquia pela preponderância individual no Modernismo. A impossibilidade de construção coletiva não sectária desse momento modernista barra o caminho que Mário até então seguia; a exemplaridade de sua obra poética não tem mais lugar nem função. Entretanto, fazendo da fraqueza força, Mário desvia sua disposição fraterna para uma expressão amorosa essencializada, de dicção e sentimento que não aspiram ao espaço público, mas refaz o Brasil e o amor em uma acolhedora atmosfera afetiva, em que consolo e realização amorosa compõem uma nova visão do amor, do sujeito e do Brasil.

Assim, após essa exposição do contexto biográfico e literário, retornamos aos versos dos "Poemas da Negra" e podemos focá-los em suas configurações de poesia amorosa. Os versos da parte I nos introduzem nesse novo universo amoroso:

\author{
Não sei por que espírito antigo \\ Ficamos assim impossíveis... \\ A Lua chapeia os mangues \\ Donde sai um favor de silêncio \\ E de maré. \\ És uma sombra que apalpo \\ Que nem um cortejo de castas rainhas. \\ Meus olhos vadiam nas lágrimas. \\ Te vejo coberta de estrelas, \\ Coberta de estrelas, \\ Meu amor!
}

Tua calma agrava o silêncio dos mangues.

A expressão poética corresponde com exatidão ao trecho da carta de Mário acima citado em que ele diz "falar por imagens", "falar vago", o que seria uma consequência do seu novo "pudor" poético, de sua aspiração a uma "invisibilidade". Depois dos dois versos iniciais, que introduzem belamente o contexto de "impossíveis" do poema, essa parte I se desenvolve toda por imagens e suas sugestões vagas: a lua sobre os mangues e o 
silêncio, a paisagem de sombra e o corpo da mulher, desdobrado no "cortejo de castas rainhas", o corpo de sombra e o céu de estrelas. Há notável aproveitamento de construções de linguagem coloquial: "um favor de" (que significa "muito", "um monte de", "uma enormidade de"), "que nem", “te vejo" (anteposição do pronome oblíquo), mas agora totalmente naturalizadas na expressão. E ainda nessa parte podemos ler, num poema de doce acolhimento e realização erótica, a nota comovida, um tipo de tristeza consolada no verso "Meus olhos vadiam nas lágrimas". Esse padrão de expressão poética se desenvolve nas doze partes do poema, sempre mantendo sua doçura imagética e seu alto poder de sugestão. Contudo, o foco principal que interessa à minha análise neste capítulo é a disposição e realização amorosa da subjetividade lírica mariodeandradiana, isto é, o modo como, dentro desse padrão expressivo do poema, o sujeito lírico se relaciona com o seu objeto amoroso. Assim, o que chama a atenção, inicialmente nesses versos da parte I, é a gravidade da mulher com que o poeta se relaciona. O último verso já anuncia: "Tua calma agrava o silêncio dos mangues", e compõe um acorde com o último verso da parte IX: "Mas você é grave sem comparação". A gravidade pressupõe domínio do olhar e do corpo, vida interior. Assim, essa mulher negra de Mário de Andrade, inspirada nos quadros de Cícero Dias, a quem o poema é dedicado, aparenta-se mais às mulheres que, em pintura, combinam a sedução de seu corpo com um domínio da situação, como a "Maya desnuda", de Goya. Essa vida interior habita igualmente os silêncios estendidos ao longo do poema, silêncios cujas variações são: indiferença, sol-posto, imobilidade, mutismo, silêncio propriamente dito - imagens expressivas do anseio de "invisibilidade" dessa etapa da poesia de Mário.

A técnica de Mário nesses "Poemas da Negra" de "falar por imagens" tem um momento feliz na escolha de sua ambientação paisagística. Inspirado pela pintura de Cícero Dias e pela paisagem de Recife, é com imagens sugeridas por esta cidade que os poemas se compõem. Entretanto, a paisagem é repleta de figurações psicológicas. A ambientação no Recife se faz no que Gilda de Mello e Souza chamou de "contaminação entre a tonalidade afetiva e o sentimento do mundo ambiente". ${ }^{252}$ Ao longo dos poemas, o céu se apresenta com a leveza e singeleza dos quadros de Cícero Dias: temos a lua, o negrume da noite, "as auras pernambucanas", a estrela Vênus. No plano propriamente terrestre, temos a doçura como sinestesia na forma de maciez: o mangue, a zona da

\footnotetext{
${ }^{252}$ SOUZA, Gilda de Mello e. A poesia de Mário de Andrade [1988]. A ideia e o figurado. São Paulo: Duas Cidades/Editora 34, 2005. p. 29.
} 
mata, o barro mole. A terra é envolvida por ventos mornos, águas, lábios. A vegetação vem com o gosto e cheiro da manga, os coqueiros e as flores amarelas do pau-d'arco secular. Junto dessas imagens, a paisagem contribui com os seus sons: além da gravidade do silêncio, ela é por vezes composta de sons estridentes que parecem indicar a ansiedade do desejo: são os grilos e os tetéus. Na última parte do poema, parte XII, o poeta colhe nas lembranças a imagem da cidade: o calor, as igrejas e as casas, os homens, o cais e a beira do rio. Ternura e desejo comungam com as formas escolhidas da paisagem por um olhar atento, acostumado ao escrutínio de formas espirituais e materiais, à especulação e ao detalhe dos objetos. Nesse movimento, Mário faz com mão admirável o poema dos quadros de Cícero Dias. Porém, o movimento não pára na contaminação entre psicologia e paisagem, mas igualmente, e aqui ultrapassando a inspiração, dá vida à mulher desenhada, o que marca a reciprocidade da realização amorosa exposta nos poemas.

A poeticidade da pele negra, as ricas conotações poéticas de sua comparação com a noite, a escuridão e a mistura de silêncio, entrega e percurso de autoconhecimento são explorados nesse poema de um modo que só tornaremos a ver na alta poesia dos poetas da negritude, Aimé Césaire e Léopold Sédar Senghor. Além do reconhecimento sem condescendência de uma beleza negra, o poeta é objeto de uma subjetividade autônoma, de uma mulher com vontade própria. Ela pode dissolver-se em amor, mas pode igualmente ensinar a "volta ao bem", impedir o poeta de beber água, sumir, adivinhá-lo. E algo mais agudo do que tudo, essa mulher sabe a diferença entre eles e não quer ser escrava. O poder democrático desse lirismo é imenso e notável. $\mathrm{O}$ processo histórico é detido e encontrado no mais íntimo envolvimento amoroso, e, mais do que reconhecido, ele é compartilhado e superado sem violência. A opressão historicamente sedimentada é subvertida a partir de dentro e sem reproduzir a agressividade que lhe é própria. Essa mulher negra tem poder de palavra e poder de silêncio, força de vontade e força de dissolução, intuição iluminadora e espontaneidade (“Teu beijo é tão beijo,/Tua inocência é dura,/Feita de camélias" - parte IV). As taras sexuais do regime escravocrata passam ao que, na esteira da poesia baudelairiana, seria o amor terno, de reconhecimento do outro e acolhimento, o amor antiburguês. ${ }^{253}$

\footnotetext{
253 "Não há escravidão sem depravação sexual" (FREYRE, Gilberto. Casa-grande \& senzala: introdução à história da sociedade patriarcal no Brasil, cit., p. 372). Baudelaire, em sua ousadia provocativa, identifica amor heterossexual e amor burguês, concebendo como rebeldia afetiva os encantos do amor lésbico. Ver OEHLER, Dolf. Quadros parisienses. São Paulo: Companhia das Letras, 1997: "Somente Lesbos [...] faz desabrochar os sonhos de profunda delicadeza e paixão que não sobrevivem a uma noite
} 
Por fim, o próprio eu lírico tem uma atitude profunda e complexa diante do objeto amoroso. O primeiro movimento do eu lírico vai da comoção à inconsciência ("Meus olhos vadiam nas lágrimas" - parte I; "Não sei se estou vivo.../Estou morto" parte II). Em seguida, ele se dissolve em vento morno e se mostra pleno de porosidade ao outro (parte III). Essa porosidade, por sua vez, não vem isenta de medo (parte IV), que, no entanto, se desfaz sobre o corpo da mulher em seu ato de "desgalhar-se" (parte V). O que se segue são finas carícias, a mão se alastrando sobre o corpo dela (parte VI), e o retorno do desejo, agora forte e estridente (parte VII). Novamente, após o desejo consumado, retornam as figuras de paz: olhar e pensamentos vagantes, a exalação de fluidos leves, sensação de eternidade, virtuosidade (parte VIII). Esse padrão de movimento, de atração, realização, paz amorosa e recomeço se mantém no poema até a parte XI. Nesse ponto surge, de relance, um sentimento caro ao poeta Mário de Andrade, o aspecto destrutivo do amor sexual (quando diz "Meus lábios são que nem destroços”), que não consegue dissipar completamente a sombra do pecado cristão, no plano religioso, e vê, no plano afetivo, a ruptura do seu ideal de "amizade amorosa", trazendo-a em seu bojo o fim, ainda que momentâneo, da idealização amorosa, e um pouco do que Freud chama de "reminiscência animal" no ato sexual humano. ${ }^{254}$ Contudo, a comunhão em que se dá esse enlace amoroso, com os elementos já citados de reconhecimento e entrega, supera o aspecto destrutivo, e logo no verso seguinte já "o mar acalanta em sossego" esses lábios, a "luz do candieiro" aprova a mulher amada, e a "lembrança boa", já na parte XII, o leva a esconder-se no momento suave, que o faz sentir-se "suavíssimo".

A composição desses movimentos psicológicos e imagéticos na realização erótica dos amantes abre uma esfera de privacidade protegida, em que os amorosos,

sequer na heterossexualidade, sobretudo no casamento. No amor lésbico, confiança, intimidade, delicadeza, dedicação, paixão e volúpia, na relação sexual burguesa, insensibilidade, egoísmo, brutalidade, violência, terror e barbarismo" (p. 248).

${ }^{254}$ O termo "amizade amorosa" está em SOUZA, Gilda de Mello e. A poesia de Mário de Andrade, cit., p. 29. Ver também FREUD, Sigmund. Psicologia do amor. Obras completas. Rio de Janeiro: Imago, 1972. v. XI: “'A anatomia é o destino'. Os órgãos genitais propriamente ditos não participaram do desenvolvimento do corpo humano visando à beleza: permaneceram animais e, assim, também o amor permaneceu, em essência, tão animal como sempre foi” (p. 172). Mário sobre a "amizade amorosa": "É esquisito: o amor realizado se torna logo parecido com amizade..." (ANDRADE, Mário de. Amar, verbo intransitivo. Belo Horizonte; Rio de Janeiro: Villa Rica, 1995. p. 102); e o personagem Elis no conto "Túmulo, Túmulo, Túmulo": "Observando, feito eu, amor sem-educação, a gente percebe mesmo que nele não tem metafísica: uma escolha proveniente do sentimento que a babosa recebe de um corpo estranho, e em seguida furrum-fum-fum. A força do amor é que ele pode ser ao mesmo tempo amizade" (ANDRADE, Mário de. Túmulo, Túmulo, Túmulo [1926]. Contos de Belazarte. São Paulo: Círculo do Livro, s/d. p. 79). 
reconhecendo-se mutuamente, podem também reconhecer-se no mundo histórico em que eles se encontraram (mas não necessariamente encontram-se, dada a invisibilidade e proteção da forma poética em que eles existem). O sujeito lírico e a mulher negra se percebem carregados de determinações históricas, mas, uma vez unidos, alcançam uma existência poética cuja natureza os protege e purifica, num misto de doce consolação e alegria serena. Nesses "Poemas da Negra", os amantes, protegidos pela própria invisibilidade do pudor da expressão poética, e separados da atuação pública pela consolação dionisíaca, fazem da realização amorosa uma arte e também um julgamento do processo histórico:

\section{Tu me adivinhas, meu amor, \\ Porém não queres ser escrava! \\ Parte V (versos 4-5)}

Pela reflexão dialética, o peso das determinações históricas sobre os amantes é percebido menos pela presença visível de sua carga opressiva do que pela sua necessária eliminação. Por ser amor que precisa realizar-se na invisibilidade, em cuja alquimia entra um difícil equilíbrio da tristeza pelo consolo, do consolo pela carícia, da carícia pelo gozo físico e, após o gozo, um retorno à invisibilidade. Na parte XII, última dos poemas, o poeta está só, mas integrou à sua invisibilidade a essencialização da realização amorosa com a mulher negra:

Lembrança boa,

Carrego comigo tua mão.

O calor exausto

Oprime estas ruas

Que nem a tua boca pesada.

As igrejas oscilam

Por cima dos homens de branco,

$\mathrm{E}$ as sombras despencam inúteis

Das botinas, passo a passo.

O que me esconde

É o momento suave

Com que as casas velhas 
São róseas, morenas,

$\mathrm{Na}$ beira do rio.

Dir-se-ia que há madressilvas

No cais antigo...

Me sinto suavíssimo de madressilvas

$\mathrm{Na}$ beira do rio.

O tom elevado da expressão permite até uma mesóclise no começo da última estrofe, que, além de enobrecer a dicção - logo naturalizada no "me sinto" -, quebra uma possível aliteração $\mathrm{d} / \mathrm{r} / \mathrm{dr}$ (se diria/madressilva) e dá ênfase maior aos "s" e "i", ecoando o "suavíssimo" que define o eu lírico ao fim do poema. O desaparecimento do poeta na essencialização da mulher amada e da paisagem, bem como na natureza translúcida das coisas que se diriam espectrais, revela mais da carga histórico-social sofrida pelos sujeitos que habitam os "Poemas da Negra" do que uma exteriorização forte e eloquente dos conflitos, já que se trata aqui de subjetividades muito fragilizadas. O que o poema deixa entrever pela sua própria natureza silenciosa e invisível é mais facilmente percebido pelo diálogo poético de Mário de Andrade e Manuel Bandeira a propósito desses "Poemas da Negra". Inicialmente, Manuel Bandeira recebeu esses poemas com reticência. Em carta de 21 de dezembro de 1930, Bandeira escreve "Ainda não sei gostar dos 'Poemas da Negra', embora nada haja ali que me desgoste". ${ }^{255}$ Ao que Mário responde, polidamente, mas tocando em um ponto essencial, que talvez a questão racial impedisse a aceitação completa do erotismo desses poemas: "talvez haja no poema, sobretudo pela falta de exotismo com que valorizei, humanizei uma negra fazendo-a sair das facilidades de concepção baudelairiana, talvez haja uma naturalidade nova que você, irredutível pessoal, inda não concedeu aos poemas". ${ }^{256}$ Ao publicar as cartas recebidas por Mário, Bandeira, em nota, refaz seu juízo, dando razão ao amigo na questão da naturalidade, mas evitando a polêmica racial: “A esperança de Mário cedo se realizou. 'Os poemas da negra' acabaram insinuando-se no meu espírito e no meu coração, e eu mesmo não podia compreender, no fim de algum tempo, como não havia gostado à primeira vista! Hoje considero-os mesmo, com os 'Poemas da amiga', das

\footnotetext{
${ }^{255}$ MORAES, Marco Antônio (Org.). Correspondência Mário de Andrade \& Manuel Bandeira, cit., p. 475.

${ }^{256}$ MORAES, Marco Antônio (Org.). Correspondência Mário de Andrade \& Manuel Bandeira, cit., p. 476.
} 
melhores coisas de Mário na lírica". ${ }^{257}$ Esses poemas de Mário proporiam, nessa perspectiva, embora motivados pelo isolamento, pelo pudor e pelo ideal de invisibilidade, e - dialeticamente - por isso mesmo, uma sensibilidade nova, uma revisão do tempo sob o signo das liberdades poéticas modernas do eu lírico e do verso meditativo polimétrico, “azul", como denominou o próprio poeta, encaminhando nosso modernismo para a revisão das suas próprias descobertas. Essa via de Mário de Andrade, que revisava o alcance modernista, formava juízo sobre nosso passado colonial e nutria o projeto de sua superação, corria contra o relógio histórico do próprio Modernismo, que passava por um processo de tribalização em torno de totens (Antropofagia, Anta, Sigma e, para o espírito leigo, Jesus Cristo, que não deixa de ser um totem). Como sentido histórico, as vertentes modernistas de 1929/1930 restabeleciam a mentalidade de "lei do mais forte" que, a bem dizer, reatava em plano literário com o coronelismo político, fazendo a República Velha reviver, cheia de diretrizes modernizantes e espírito arcaizante, no Brasil que se encaminhava para a Revolução de 30. Isolado em seu projeto de fraternidade brasileira, Mário de Andrade, sem encaixe histórico nesse momento, essencializou seu projeto de Brasil e o trouxe para uma poesia de impossíveis, reagrupando os destroços de uma filia coletivizada e, acabando de destruí-los, os presentificou em sua invisibilidade.

$$
* * *
$$

O objetivo de tornar a poesia expressão completa de sua subjetividade se faz presente também na poesia amorosa. Mário declara ter tido quatro amores eternos:

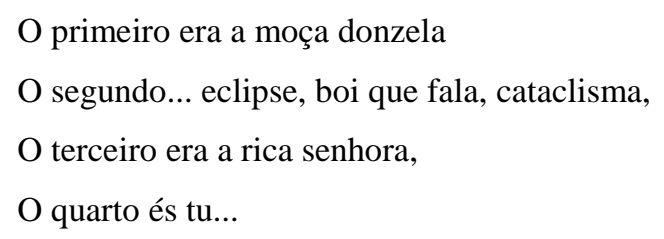

“Girassol da Madrugada”, parte V (versos 5-9)

Os três primeiros amores eternos correspondem aproximadamente a partes reconhecíveis de sua obra poética: a moça donzela de Losango cáqui, a mulher dos "Poemas da Negra" e a Maria do "Tempo de Maria". Sem a intenção detetivesca de

${ }^{257}$ MORAES, Marco Antônio (Org.). Correspondência Mário de Andrade \& Manuel Bandeira, cit., p. 477 , nota 76. 
achar e documentar na realidade as pessoas empíricas amadas pelo poeta, temos - o que é o bastante - a equivalência entre os "amores eternos" e os objetos amorosos específicos, elaborados liricamente. O último amor eterno é envolto em segredo e seu poema é "Girassol da Madrugada". Antes de determo-nos no poema, cumpre esclarecer algo sobre a mistura de insinuações alcoviteiras e a opacidade sistemática em torno da sexualidade de Mário de Andrade. ${ }^{258}$ Do ponto de vista empírico, do homem Mário de Andrade, essa discussão tem interesse menor e ao longo do tempo se prendeu a intenções, ou de difamação, ou da proteção da respeitabilidade de um grande nome, sempre lidando com a pesada carga de preconceitos machistas de nossa vida prática e intelectual. Como disposição do eu lírico, no entanto, do ponto de vista prioritariamente literário, o que se tem é uma sexualidade complexa, polimorfa ou, mais propriamente, tendendo à homossexualidade. Esse esclarecimento inicial tem como objetivo preparar a inquirição da atmosfera de segredo que paira nos versos das sete partes de "Girassol da Madrugada" e em relação à pessoa que os inspirou, que atende abaixo do título do poema pelas iniciais "R. G.". ${ }^{259}$ Tentar reconhecer quem seria o destinatário desse poema é menos importante do que reconhecer a sua natureza secreta, no interior de uma obra poética pródiga de informações sobre a vida íntima e social do poeta. Os versos da parte I desenvolvem a natureza da relação amorosa elaborada pelo poema:

De uma cantante alegria onde riem-se as alvas uiaras

Te olho como se deve olhar, contemplação,

E a lâmina que a luz tauxia de indolências

É toda um esplendor de ti, riso escolhido no céu.

Assim. Que jamais um pudor te humanize. É feliz

Deixar que o meu olhar te conceda o que é teu,

Carne que é flor de girassol! sombra de anil!

Eu encontro em mim mesmo uma espécie de abril

Em que se espalha o teu sinal, perpetuamente.

\footnotetext{
${ }^{258}$ Grata exceção é o já citado livro de Moacir Werneck de Castro, que dedica a este tema em seu perfil biográfico de Mário o capítulo V - "O sublime inferno", capítulo medido, cuidadoso e cheio de respeito, sem nada ocultar da vida amorosa de nosso poeta (CASTRO, Moacir Werneck de. Mário de Andrade: exílio no Rio. Rio de Janeiro: Rocco, 1989).

${ }^{259}$ Há dois comentários em cartas de Mário de Andrade sobre o poema e a dedicatória, reproduzidos em ANDRADE, Mário de. Poesias completas, cit., p. 525.
} 
“Girassol da Madrugada” é de 1931, como documenta a correspondência de Mário com Bandeira. Em carta de 28 de março de 1931, Mário copia essa mesma primeira parte do poema, mas escreve ao amigo especificamente sobre os seus sentimentos a respeito de seu novo amor e nada sobre a forma do poema. ${ }^{260} \mathrm{Em}$ momento posterior, retornarei à concepção de amor de Mário exposta nessa carta. Por enquanto, é preciso ainda notar a familiaridade de estilo entre esses versos e os versos dos "Poemas da Negra". São ritmos largos e lentos, de ambientação translúcida e realidades desmaterializadas. Contudo, em relação aos "Poemas da Negra", a solidão amorosa de "Girassol da Madrugada" é menos triste e mais luminosa. A cor do poema não é azul, mas dourado. ${ }^{261}$ Esse dourado pode ser percebido pelo corpo e pela carne do objeto amoroso apresentados nessa parte I: o corpo é um esplendor de uma lâmina de luz tauxiada de indolências, e a carne é "flor de girassol". Dourado como é, então, o poema possui um excesso de sutilezas, de gradações de luz, brilho e sensibilidade, cujo anseio é a perenidade desse amor sublime, como afirma o poeta nos dois últimos versos. Ainda em relação aos "Poemas da Negra", deve-se notar no primeiro verso da segunda estrofe citada de "Girassol da Madrugada", o poeta se desfaz da atitude de "pudor". Não é fácil entender o que o poeta quer dizer com "que jamais um pudor te humanize", principalmente depois da defesa do pudor a propósito dos "Poemas da Negra", com os quais o "Girassol da Madrugada" tem tantas afinidades. Uma hipótese possível é a de que o pudor seria um ideal de invisibilidade dos amorosos diante da vida, uma subtração em relação à existência, que revelaria a fragilidade humana em um mundo hostil, já nos versos citados, porém, os amorosos não querem subtrair-se, mas elevar-se sobre a existência, em uma purificação de sentido ascensional. As subjetividades envolvidas nessa poesia amorosa assumem no interior do poema um ideal de sublimação dourada, perenizados por uma luz purificadora. Esse ideal, manifestação máxima da filia mariodeandradiana, é atingido por uma série espelhamentos e indiferenciações, de finas implicações poéticas e sexuais. A principal característica dos amorosos no poema é a

\footnotetext{
${ }^{260}$ MORAES, Marco Antônio (Org.). Correspondência Mário de Andrade \& Manuel Bandeira, cit., p. 495-496.

${ }^{261}$ Mário expõe as "cores" de seus poemas "olímpicos" em carta a Bandeira de 10 de agosto de 1934: "Eu desejei mesmo um certo olimpismo, uma certa sobre-elevação acima dos tumultos terrenos, desprezando o terra-a-terra... Deu no tom azul dos 'Poemas da negra' e da 'Amiga', no tom mais doirado do 'Girassol' e quase branco do 'Rito do irmão pequeno'. E acabou dando este cinza claro do 'Grifo da morte"' (MORAES, Marco Antônio (Org.). Correspondência Mário de Andrade \& Manuel Bandeira, cit., p. 582$583)$.
} 
sua indistinção de gênero. Os amantes alcançam uma realização amorosa dessexualizada, cujo clímax não se alcança pelo gozo do corpo, mas pelo espelhamento das almas, os "espelhos maduros", como se pode ler na parte II do poema:

Diga ao menos que nem você quer mais desses gestos traiçoeiros

Em que o amor se compõe feito uma luta;

Isso trará mais paz, porquanto o caminho foi longo,

Abrindo o nosso passo através dos espelhos maduros.

Você não diz, porém o vosso corpo está delindo no ar,

Você apenas esconde os olhos no meu braço e encontra a paz na escuridão.

A noite se esvai lá fora serena sobre os telhados,

Enquanto o nosso par aguarda, soleníssimo,

Radiando luz, nesse esplendor dos que não sabem mais pra onde ir.

Indiferenciados sexualmente e sublimemente espelhados, os elementos mais importantes do amor nesse poema convergem para uma ambivalência sexual, para uma expressão amorosa feita de indistinção e duplicidade sexual do objeto amoroso e do eu lírico, e cuja tendência mais evidente é para a homossexualidade. O fato de o objeto amoroso ser ao mesmo tempo igual e amante do sujeito lírico expõe sua ambivalência sexual, que se faz ver aqui em sua disposição homoerótica. Podemos acompanhar aqui a análise da sexualidade de Freud, quando diz: "Assim, o objeto sexual é uma espécie de reflexo da própria natureza bissexual do indivíduo". ${ }^{262}$ A indiferenciação e a identificação amorosa estão também nas imagens poéticas que desdobram a imagem do eu lírico: espelho, Narciso, lagoa. Além disso, há a presença de alguns objetos que constroem no poema uma simbologia fálica: a lâmina, que é o corpo amado; o dedo curioso, o qual acaricia o rosto do eu lírico; bem como uma evocação um pouco mais longínqua, a asa gratuita que roça a lagoa. E como função elevada do espelhamento e da eliminação de censuras externas ou introjetadas, há a característica que faz par com o segredo nesse poema, o silêncio. ${ }^{263}$ Como elevação da relação amorosa, note-se que o

\footnotetext{
${ }^{262}$ FREUD, Sigmund. Três ensaios sobre a Teoria da Sexualidade, cit., p. 145.

263 "Silêncio" é o primeiro título da parte V do poema. Assim Mário o chama em carta de 2 de maio de 1931 a Manuel Bandeira, concebendo-o, então, como um poema separado. Ver MORAES, Marco Antônio (Org.). Correspondência Mário de Andrade \& Manuel Bandeira, cit., p. 502. A ambivalência dos pronomes tu/você alternados nas diferentes partes do poema não são, como poderia parecer, evidência
} 
pronome possessivo de "você", no poema, é "vosso/a", deixando evidente a atribuição de nobreza e importância à pessoa com quem se fala. E o silêncio, envolvido no processo de purificação, ocorre nesse verso, que é um dos principais de todo o poema: "Você não diz, mas o vosso corpo está delindo no ar". Silêncio e processo de sublimação incorpórea fazem acorde no mesmo verso, com a sutileza poética da palavra "delindo", cuja implicação de violência, do verbo delir, que significa dissolver, desaparecer, extinguir, é atenuada pela reverberação sonora "de - lindo", com "lindo" adjetivando o corpo e acentuando uma consoante "l" luminosa. Essa necessidade de segredo e silêncio para alcançar a identificação luminosa e os espelhos maduros tem no poema uma formulação mais explícita na sua parte IV:

IV

Não abandonarei jamais de-noite as tuas carícias,
De-dia não seremos nada e as ambições convulsivas
Nos turbilhonarão com as malícias da poeira
Em que o sol chapeará torvelins uniformes.
E voltarei sempre de-noite às tuas carícias,
E serão búzios e bumbas e tripúdios invisíveis
Porque a divindade muito naturalmente virá.
Agressiva Ela virá sentar em nosso teto,
E seus monstruosos pés pesarão sobre nossas cabeças,
De-noite, sobre nossas cabeças inutilizadas pelo amor

Os elementos primitivos, de matriz mítica, são configurados nessa estrofe como elementos de repressão. Sua força e seu poder de destruição, associados à categoria de "divindade", fazem supor a aplicação de uma lei, a severidade da punição a quem se desviou das convenções estabelecidas. O amor, além de superar a aplicação dessa lei divina, se coloca acima da racionalidade humana. As "cabeças inutilizadas pelo amor" são abandonadas em favor de um florescimento, de um completamento amoroso que pode desprezar a razão. Mesmo uma possível sombra do pecado é transfigurada, absorvida em uma noite sem punição. Contudo, há outra ambivalência, ou indistinção, que ocorre na natureza da relação amorosa, pois ela é ao mesmo tempo perigosa e pura.

de ambivalência sexual, pois a mesma alternância pronominal ocorre em "Poemas da Negra" e "Poemas da Amiga". 
Nesse sentido, além dos "monstruosos pés" da divindade, a imagem das "alvas uiaras" do primeiro verso da parte I é paradigmática. As uiaras, imagem indígena que corresponde à sereia grega, cantam e atraem os marinheiros à morte. A promessa das sereias é tornar presente o que já passou, prender o sujeito em seu passado. ${ }^{264}$ Talvez seja aqui possível a aproximação entre o passado do tempo cronológico de uma vida que as sereias evocam - e o tempo psicológico da maturidade. Seguindo a linha de Freud, com que o modernismo de um modo geral e particularmente Mário de Andrade estavam em contato, a constituição do $e u$ e a constituição da sexualidade são um mesmo processo. Assim, o desligamento da subjetividade de uma identificação com o todo e seu decorrente sentimento de onipotência, ou seja, o reconhecimento do sujeito como "indivíduo", o que está separado, e que se distingue do todo e com ele interage, corresponde, ou melhor, pressupõe a superação da sexualidade "polimorfa e perversa" da infância. Em seu momento de imaturidade, sempre nos termos de Freud, a sexualidade não concentrou sua satisfação no órgão sexual e não condicionou a especificidade do objeto amoroso. Um bonito tratamento dessa labilidade sexual no período anterior à conformação individual do sujeito está no conto de Mário de Andrade chamado "Frederico Paciência". ${ }^{265}$ Há diversas afinidades entre o poema "Girassol da Madrugada" e esse conto. Inicialmente, a apresentação de Frederico Paciência pelo narrador do conto lembra o objeto amoroso de nosso poema: "Frederico Paciência era aquela solaridade escandalosa". ${ }^{266}$ Em seguida, o sentimento do narrador é de indiferenciação amorosa: "Quis ser ele, ser dele, me confundir naquele esplendor". ${ }^{267}$ Como síntese de solaridade e indiferenciação amorosa, o narrador do conto diz: "Como que havia entre nós dois um sol que não permitia mais nos vermos mutuamente". ${ }^{268} \mathrm{Em}$ relação ao silêncio, há essa passagem: "Vivíamos por vezes meia hora sem uma palavra, mas em que nossos espíritos, nossas almas entreconhecidas se entendiam e se irmanavam com silêncio vegetal". ${ }^{269}$ Por fim, para nos atermos apenas às simetrias mais

\footnotetext{
264 ADORNO, Theodor W.; HORKHEIMER, Max. Dialética do esclarecimento. Rio de Janeiro: Jorge Zahar, 1985. p. 43. Na primeira versão do poema enviada a Manuel Bandeira, o primeiro verso é: "De uma cantante alegria onde riem-se as alvas sereias" (MORAES, Marco Antônio (Org.). Correspondência Mário de Andrade \& Manuel Bandeira, cit., p. 495).

265 “O interesse do escritor [Mário de Andrade] pelo fenômeno da fluidez das fronteiras da sexualidade se manifesta com nitidez no conto "Frederico Paciência"' (CASTRO, Moacir Werneck de. Mário de Andrade: exílio no Rio, cit., p. 95).

266 ANDRADE, Mário de. Frederico Paciência [1924-1942]. Contos novos. São Paulo: OESP Gráfica, 1997. p. 96.

${ }^{267}$ ANDRADE, Mário de. Frederico Paciência [1924-1942], cit., p. 96.

268 ANDRADE, Mário de. Frederico Paciência [1924-1942], cit., p. 101.

269 ANDRADE, Mário de. Frederico Paciência [1924-1942], cit., p. 108.
} 
evidentes, há essa descrição do olhar amoroso, cuja atenção é centrada nos olhos e na boca, no conto: "Percebi o mutismo dele, entendi por que era, mas não podia, custei a retirar os olhos daquela boca tão linda. E quando nossos olhos se encontraram, quase assustei porque Frederico Paciência me olhava, também como eu estava, com olhos de desespero, inteiramente confessado", ${ }^{270}$ e no poema, no início da parte III: "Si o teu perfil é puríssimo, si os teus lábios/São crianças que se esvaecem no leite,/Si é pueril o teu olhar que não reflete por detrás". Há, ainda, muitas outras descrições do desejo homoerótico como algo sublimado e belo, o qual resiste, a duras penas, à reprovação social objetiva e à reprovação subjetiva introjetada. O que está mais explícito em "Frederico Paciência" é o momento pré-maduro em que se apresenta essa sexualidade polimorfa. Em "Girassol da Madrugada", porém, a puerilidade da sexualidade polimorfa é superada por um momento de maturidade plena. O poeta caminha por esferas pósfreudianas e originais, pois não concebe a maturidade como renúncia à bissexualidade, mas como realização equilibrada, racional e consciente dos impulsos sexuais presentes no homem maduro. Aqui saímos da esfera psicanalítica das motivações inconscientes e dos efeitos dessas motivações na consciência e entramos na esfera da realização lúcida e reflexão consciente de uma sexualidade polimorfa que persiste na maturidade. $\mathrm{O}$ termo que o próprio Mário de Andrade usou para definir a si próprio foi "pansexualismo", como escreve em carta a Oneyda Alvarenga:

Há também ainda [...] um outro elemento, delicado de tratar, mas que tem importância decisória em minha formação: a minha assombrosa, quase absurda, o Paulo Prado já chamou de "monstruosa" sensualidade. O importante é verificar que não se trata absolutamente dessa sensualidade mesquinhamente fixada na realização de atos de amor sexual, mas de uma faculdade que, embora sexual sempre e duma intensidade extraordinária, é vaga, incapaz de se fixar uma determinada ordem de prazeres que nem mesmo são de ordem física. Uma espécie de pansexualismo, muito mais elevada e afinal de contas, casta, do que se poderia imaginar. ${ }^{271}$

Se há uma natureza polimorfa nessa pansexualidade, o que apontaria para a permanência do seu estágio infantil, não há nela qualquer perversidade. Ao contrário, o amor presente em "Girassol da Madrugada" pressupõe não só a maturidade de um eu lírico plenamente consciente e dirigindo seus impulsos pelo entendimento mas também

\footnotetext{
270 ANDRADE, Mário de. Frederico Paciência [1924-1942], cit., p. 111.

${ }^{271}$ Carta de 14 de setembro de 1940. Apud CASTRO, Moacir Werneck de. Mário de Andrade: exílio no Rio, cit., p. 90.
} 
realiza na expressão amorosa o seu poema mais elevado. A falta de uma individuação sexual se desenvolve em um excesso de cuidado e controle, subjetivo e linguístico, da expressão literária.

Mário de Andrade faz, nos versos de "Girassol da Madrugada", a naturalização do homoerotismo, que é formulado como um amor destituído de taras, reprovações, sentimento de anormalidade etc. O poeta, além de naturalizá-lo em sua linguagem, eleva magistralmente o que se costumava considerar "desvios da norma”. Antonio Candido, ao estudar um dos primeiros baudelairianos brasileiros, Fontoura Xavier, e dos mais interessantes, notou uma recorrência em nossos poetas: "Na poesia brasileira (penso no que dizem os versos, não no comportamento dos poetas), é visível a vertente dos desvios da norma: sadismo em Bernardo Guimarães, masoquismo em Casimiro de Abreu, erotismo solitário em Álvares de Azevedo, voyeurismo em Bilac, necrofilia em Alberto de Oliveira, senso da decomposição em Augusto dos Anjos, angústia do impulso sexual irregular em Mário de Andrade, autocastração punitiva em Drummond". ${ }^{272}$ É a superação desse "impulso sexual irregular" que pode ser vista no poema em questão. Em "Girassol da Madrugada”, o que é normalmente sentido como opressão de desejos escusos, o que é vítima na interioridade da repressão social objetiva e da repressão subjetiva, do superego, e que normalmente se resolve pela violência praticada, ou contra si, ou contra o objeto sexual, isto é, os impulsos homossexuais como fatores de uma sexualidade sadomasoquista, é aqui aceito e transformado em uma relação amorosa feita de abandono de si e entrega ao outro. Essa comunhão amorosa tem de lidar constantemente ao longo do poema com suas consequências perigosas. Na parte I, além das uiaras, há o perigo do pudor. Na parte II, é preciso abandonar "gestos traiçoeiros/em que o amor se compõe feito uma luta". Essa recorrência da purificação do ato de entrega e superação amorosa de perigos, esse "desvio triunfal da verdade", inclui na solenidade sublime do amor realizado a presença superada de todas as suas dificuldades. Toda a linguagem do poema é uma depuração levada a cabo com maestria, em que o ritmo e a melodia evocam um andamento musical vago, "andante", e visam a um desarmamento não violento das forças repressivas pela linguagem, que flui em direção à entrega. Outra imagem de completamento amoroso que se vê no poema é a de Narciso, presente na parte VI:

${ }^{272}$ CANDIDO, Antonio. Pomo do Mal, cit., p. 256. 
Os trens-de-ferro estão longe, as florestas e as bonitas cidades,

Não há senão Narciso entre nós dois, lagoa,

Já se perdeu saciado o desperdício das uiaras,

Há só meu êxtase pousando devagar sobre você.

Ôh que pureza sem impaciência nos calma

Numa fragrância imaterial, enquanto os dois corpos se agradam

Impossíveis que nem a morte e os bons princípios.

Que silêncio caiu sobre vossa paisagem de excesso dourado!

Nem beijo, nem brisa... Só, no antro da noite, a insônia apaixonada

Em que a paz interior brinca de ser tristeza.

Esse desarmamento de um mundo repressivo é feito explicitamente no nível do significado. O poeta afasta os trens-de-ferro, as florestas, as bonitas cidades. Afasta também a tentação das uiaras, as ambições mundanas, bem como as grandes alegrias e realizações estão longe, pois encontra a plenitude em uma "paz interior" que "brinca de ser tristeza", em um verso que não se poderá nunca elogiar o suficiente (como aliás a beleza de toda essa segunda estrofe, que é de tirar o fôlego). Igualmente o ritmo largo e grave, a melodia doce e terna dos versos afastam, pelo seu poder de silêncio, a presença do mundo. De maneira doce e terna, silenciosa e secreta, metamorfoseada em uma fulgurante luz dourada, o que o poema leva a cabo é uma purificação destrutiva das determinações objetivas do mundo, que é recriado amorosamente em um nível superior. Assim, Mário de Andrade opera com um tipo de dionisismo amoroso muito original, em que o ciclo mítico morte-ressurreição é transformado em um processo de destruição purificadora e recriação luminosa. Para alcançar esse nível de amor e poesia, esse dionisismo amoroso original, há o abandono da racionalidade na parte IV do poema, como já vimos. Há, porém, outras forças que precisam ser abandonadas, além da racionalidade. O corpo é uma delas: "Você não diz, porém o vosso corpo está delindo no ar" (parte II, verso 5). A fonte do prazer é sensorial: o toque das carícias, a plenitude do olhar, mas a realização é incorpórea, uma "fragrância imaterial” (parte VI, verso 6). Outro abandono é o do tempo, que ocorre na parte VII, última do poema: 
A noite se esvai lá fora sobre os telhados

Num vago rumor confuso de mar e asas espalmadas,

$\mathrm{Eu}$, debruçado sobre vossa perfeição, num cessar ardentíssimo,

Agora pouso, agora vou beber vosso olhar estagnado, ôh minha lagoa!

Eis que ciumenta noção de tempo, tropeçando em maracás,

Assusta guarás, colhereiras e briga com os arlequins,

Vem chegando a manhã. Porém, mais compacta que a morte,

Para nós é a sonolenta noite que nasce detrás das carícias esparsas.

Flor! Flor!...

Graça dourada!...

Flor...

O tempo segue um rumo que hostiliza, traz o som dos maracás em que tropeça, assusta animais e flores, desfaz a alegria noturna do arlequim com a aproximação da manhã. Porém, o poeta rejeita a noite que se esvai, trazendo a luz do dia, seus sons e, por consequência, a sociabilidade, os olhares, a força da repressão. O poema desarma a ação do tempo, estendendo a noite que nasce da carícia dos corpos sobre a manhã que chega. Por um paradoxo próprio do processo dionisíaco, há uma fulguração simultânea de elementos opostos: é pela extensão da noite que emerge a luz da flor, a graça dourada. $\mathrm{O}$ poeta reverte a noite perpétua das carícias, mais compacta que a morte, em luminosidade sublime do mundo dos amorosos. Essa aniquilação sem violência das determinações concretas, ou melhor, essa dissolução das determinações objetivas na noite luminosa dos amorosos cria o tempo próprio do amor homossexual elevado, o tempo fora do tempo. A própria palavra, carregada como é dos sedimentos da vida humana, da vida social mais propriamente, precisa esvair-se. Por isso, o poema tem, no seu significado íntimo, uma intenção silenciante. O poema busca, a todo custo e com sucesso, exprimir com palavras o que se alcança pelo silêncio. Todo som é longínquo e traz uma ameaça. A pureza ambicionada pelo poema exige um esforço tamanho, que mal esconde a carga pesada das opressões contra o que ela luta, que qualquer concretude, ainda a mais vaga palavra articulada, pode pesar sobre esse véu incorpóreo da poesia luminosa e evocar outros pesos, entre eles, o do pecado, trocando a "graça dourada" por duros castigos punitivos. 
Um desenvolvimento desse homoerotismo composto de indiferenciação sexual e espelhamento é a imagem de Narciso. De certa forma, o repouso tão almejado pela subjetividade lírica de Mário de Andrade encontra sua manifestação mais congenial em uma comunhão amorosa em que o eu lírico imerge na própria imagem, que lhe responde como um duplo acolhedor de si mesmo. No entanto, esse duplo não é mortal, e a imagem de Narciso leva ao reconhecimento, e não à morte:

\footnotetext{
Não há senão Narciso entre nós dois, lagoa,

Já se perdeu saciado o desperdício das uiaras,

Há só meu êxtase pousando devagar sobre você.

Parte VI (versos 2-5)
}

Construção imagética das mais ousadas, que uma educação poética tradicional julgaria absurda, nela Narciso não é a imagem da morte pela paixão por si próprio, maldição mítica, mas encontro de si mesmo no outro, operado por comunhão e carinho, sem a violência da posse e o ricocheteio de autodestruição. O percurso que normalmente é de destruição ${ }^{273}$ - duplo, espelho, ausência de si no outro, reconhecimento do outro em si é nesse poema operado como percurso de realização amorosa plena e sublime, um Absoluto amoroso. Eis o ponto de chegada desse dionisismo amoroso original de Mário, para o qual ele precisa eliminar as determinações concretas e criar um mundo luminoso de amor. Dessa forma, o poeta resolve o problema essencial do poema: como tornar dizível aquilo que pela própria denominação religiosa é o indizível, o "pecado nefando". Como tornar traço essencial do sujeito aquilo que socialmente o torna um sujeito inaceitável. Como conquistar a expressão verbal da elevação amorosa àquilo que, pela sua própria enunciação verbal, pesa como uma condenação no mundo dos homens e no reino de Deus. O resultado é o poema mais cuidadoso de Mário de Andrade, aquele em que a honestidade do poeta consigo mesmo percorria um campo minado, em que sua mais íntima e frágil sensibilidade era alvo fácil da agressão mais bruta e gratuita. Essa última expressão amorosa, a mais difícil e a maior de todas, ilumina uma sexualidade ambivalente, um "pansexualismo", que não recuou diante de sua complexidade e que

\footnotetext{
${ }^{273} \mathrm{Na}$ tradição da lírica amorosa ocidental, há a esse respeito uma esclarecedora passagem sobre a imagem de Narciso na canção "Can vei la lauzeta mover" do provençal Bernartz de Ventadorn: "Miralhs, pus me mirei en te,/m'en mort li sospir de preon,/c'aissi.m perdei com perdet se/lo bels Narcisus en la fon" ("Ó espelho, depois que me mirei em ti, comecei a morrer à força de suspiros; pois perdi-me do mesmo modo por que se perdeu na fonte o formoso Narciso"). Original e tradução em SPINA, Segismundo. A lírica trovadoresca, cit., p. 150.
} 
não atuou com violência sobre os seus supostos inaceitáveis. Como resultado dessas sutis e rigorosas operações poéticas, o poeta se eleva das determinações sociais e ideológicas da vida brasileira, que, no entanto, são as suas referências fundamentais, e pode dizer, sem carregar consigo o peso de qualquer culpa ou opressão:

E eu afinal repousei dos meus cuidados.

Parte V (verso 5) 


\section{CAPÍTULO IV - SENTIMENTO RELIGIOSO DA VIDA}

Só existe uma virtude, com que a Fé se confunde,

é Charitas, vermelha, incendiada de amor.

Mário de Andrade. O banquete

O único poema de assunto religioso de Mário de Andrade, "Religião", de Paulicéia desvairada, não fala senão da vida. Não há nada nos versos agitados que compõem o poema daquela calma grave e solene que caracteriza a oração religiosa. Antes, as palavras carregam uma euforia combativa, uma intensidade expressiva da vida mundana da subjetividade lírica, que fazem a antítese do sentimento religioso. A oração propriamente dita mal começa a ser pronunciada e é interrompida pelo fervor de vida e paixão que o poeta deposita no mundo:

\footnotetext{
"Santa Maria, mãe de Deus..."

A minha mãe-da-terra é toda os meus entusiasmos:

Dar-lhe-ia os meus dinheiros e minhas mãos também!

Santa Maria dos olhos verdes, verdes,

Venho depositar aos vossos pés verdes

A coroa de luz de minha loucura!
}

(versos 23-28)

São versos extraordinariamente fracos e dão a impressão de que o poeta transpôs as técnicas de vanguarda usadas ao longo de todo o livro para a expressão de uma carolice infantil. $\mathrm{O}$ excesso de exclamações contradiz a solenidade da oração e o recolhimento que a reza pressupõe, embora o próprio poeta diga "Quem não souber rezar, não leia Religião" no "Prefácio Interessantíssimo". O verso harmônico: "Catolicismo! Sem pinturas de Calixto!... As humildades..." contradiz no acorde expressivo a própria natureza da humildade exclamada, mais próxima do sussurro monódico da ladainha ou do cantochão. Por fim, a própria voz do poema deseja expandir-se e exorta as "naves de Santa Efigênia" a cantar e dizer dos fervores religiosos do poeta. Esse fervor ingênuo e sincero não consegue afinar-se com as categorias transcendentes do religioso, e essa desafinação é sentida pelo poeta e expressa nos últimos versos, em que deseja a "Hospedaria dos Jamais Iluminados". O poema fracassa, mas aponta uma direção. 
Embora dotado de fé ardente, o poeta não se sente um "eleito de Deus"; ao contrário, o sentimento que a subjetividade lírica tem de si própria lança-a entre os marginalizados, que não participam de uma ordem espiritual superior. No momento em que unir os pontos fracos deste poema e lhes der um sentido apropriado, Mário vai alcançar uma elaboração poética adequada ao seu sentimento religioso. Desse modo, a energia de uma fé ardente, porém não iluminada pelo deus católico, a sensualidade mundana e a confiança na construção de uma humanidade melhor vão estar na base de seus poemas profundamente religiosos, mas de uma religião da vida.

O poeta que desloca a fé de deus e a projeta para os homens seus iguais cumpre na poesia uma espécie de apostolado. Compõem esse apostolado a disposição amorosa da subjetividade lírica e o seu desejo de exemplaridade. Um apostolado de amor e exemplaridade em poesia moderna não vem sem contradição, como pretendo demonstrar ao longo da análise de alguns poemas. O fator distintivo, do qual surgem as contradições mais instigantes, é a qualidade laica desse apostolado. Deve-se notar que a religiosidade não está ausente da poesia moderna, e, ao contrário, constitui-lhe uma característica fundamental. Mas é na natureza dessas disposições religiosas que podem ser buscados os diferentes sentidos da poesia moderna. Sem a pretensão de panorama, podemos acompanhar como Mário de Andrade se opõe às duas vertentes religiosas mais extremas da poesia moderna. A primeira, a religio poetae, ${ }^{274}$ cuja origem moderna remonta a Mallarmé, que, por sua vez, remonta ao orfismo, vira as costas ao mundo da vida empírica, num cultivo radical dos valores poéticos da linguagem e da sensibilidade. Em outras palavras, uma vida superior calcada no esteticismo. Dessa religio poetae Mário sempre esteve distante, por temperamento e por partido estético, pois sua educação estética se fez naquele momento de retorno à vida, que era a forma de a vanguarda europeia superar o orfismo simbolista. A outra forma de religiosidade, propriamente católica, estava também pejada de interesses mundanos, interesses políticos propriamente reacionários, e buscava sustar o curso da história. A exploração poética dos procedimentos modernos virava as costas para o rendimento que poderia ter seu correspondente complemento na experimentação social e se voltava para a preservação de valores éticos e morais. A essa vertente, que teve seu momento no Brasil com a "poesia em Cristo" de Jorge de Lima e Murilo Mendes, a poesia de Mário de

274 “... uma religião privada, uma religio poetae irreconciliável com as exigências do mundo público" (HAMBURGUER, Michael. A verdade da poesia: tensões na poesia modernista desde Baudelaire. São Paulo: Cosac Naify, 2007. p. 138). 
Andrade vai opor-se frontalmente. Seu apostolado poético também veiculava aspectos morais e éticos, sem dúvida, mas estes procuravam agir de modo integrado e progressista na vida humana dos homens que se fariam homens melhores neste mundo, sem recompensa em outro e sem a sombra do pecado. Para Mário, em suma, tratava-se de um sentimento religioso da vida.

Ao contrário, então, de "Religião", diversos poemas de assunto profano recebem uma inflexão religiosa. O poeta elabora um tipo de religiosidade que se entrega à vida das pessoas que o rodeiam e procura dar-lhes um sentido mais elevado. ${ }^{275}$ Seu escopo é universal, mas sua atuação específica é sobre a realidade brasileira, a realidade dos homens que o poeta sente como seus iguais, no modo de sentir e se comportar, como expõe em "O Poeta Come Amendoim”, poema que abre o livro Clã do jabuti:

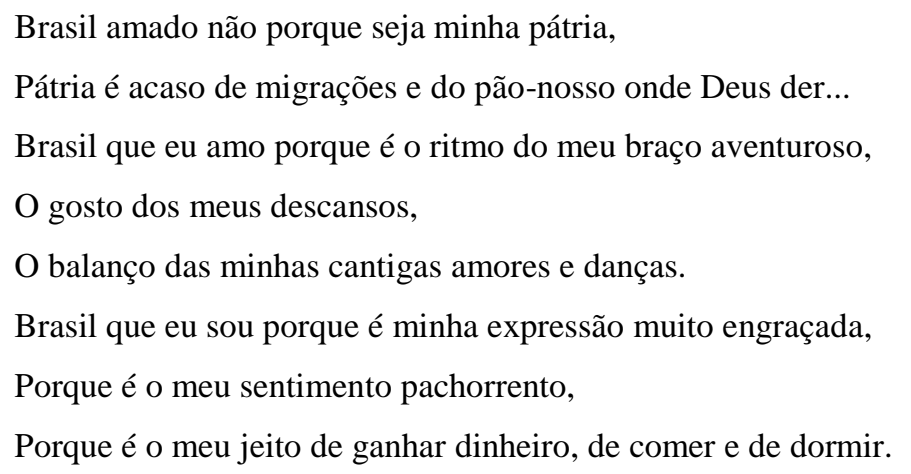

(versos 28-35)

Essa religiosidade da vida ao mesmo tempo se entrega à vida brasileira e comunga com o Brasil presente no próprio sujeito lírico, o Brasil que ele traz em si, por autoanálise ou por incorporação voluntária. Mário de Andrade, em momento de grande efervescência poética, entre 1924-1925, escreveu, certamente sem premeditação, alguns poemas em que o entusiasmo pela vida brasileira correspondia ao ânimo e ao significado das diferentes partes do dia. Assim, às atividades da manhã ele escreveu a "Louvação Matinal" (1925), ao devaneio vespertino ele elaborou a "Louvação da Tarde" (1925) e aos poderes noturnos ele compôs o "Noturno de Belo Horizonte" (1924). Em cada um deles, o sujeito lírico e as características do Brasil se relacionam e se direcionam para uma fusão. Se observados em conjunto, tendo ou não o poeta os concebido como conjunto, não importa, esses três poemas configuram uma disciplina devota de um poeta

\footnotetext{
${ }^{275}$ Como diz Antonio Candido sobre Mário: "Tinha o culto da solidariedade humana e só se entenderá a sua obra levando isto em conta" (CANDIDO, Antonio. Lembrança de Mário de Andrade. O observador no escritório. Rio de Janeiro: Ouro sobre Azul, 2008. p. 92).
} 
em busca de si e de sua nação que, finalmente encontrados ou descobertos, deveriam ser espalhados como uma boa-nova. A entrega do sujeito lírico ao Brasil se transforma em um sacerdócio que produz um tipo de oração laica para cada parte do dia, e dessa comunhão do poeta com a vida brasileira surge um breviário laico, um livro das horas da vida comum.

\section{Breviário Laico: I. Manhã}

O poema de Mário que inicia esse dia aberto à religião da vida é "Louvação Matinal", poema de 1925, recolhido no livro Remate de Males. É o poema do corpo que acorda e desperta os sentidos para o dia que começa, e é no corpo do sujeito lírico do poema que essa manhã desponta. O sujeito lírico é totalmente poroso à manhã que louva, e expressa nos versos um ideal matinal de vida. A cada parte do dia que o poeta louva, manhã, tarde ou noite, ele vai entregar-se plenamente ao momento especificado, e a nenhuma parte desse dia religiosamente vivido caberá a primazia na sensibilidade do poeta. O projeto matinal de "Louvação Matinal", o devaneio de "Louvação da Tarde" e a festa de "Noturno de Belo Horizonte" só desenham a imagem integral do poeta se colocados em conjunto. Se em dado momento de sua obra poética a manhã ou a noite forem particularmente privilegiadas, por exemplo, em "Manhã", do livro Remate de Males, ou em "A Meditação sobre o Tietê", respectivamente, isso ocorrerá em razão da posição da sensibilidade e do pensamento do poeta naquele momento de sua obra, e não de uma disposição essencial da sua subjetividade. Assim, nesse momento matinal, o despertar do eu lírico apreende a aurora como símbolo e se faz permeável ao dia que começa, dirigindo sua fé para esse dia que, ao nascer, promete um mundo novo a ser construído:

É de manhã. Se sente a fadiga boa do sono.

Porém o corpo estica, chupando com os poros abertos,

Toda a luz, todo o frescor, todo o ímpeto da manhã.

Eu fiz da minha vida sempre um rasgo matinal...

(versos 1-4)

Este último verso coloca o sujeito lírico no centro da economia formal de um poema tão dinâmico e já prefigura o movimento íntimo que vamos acompanhar até o 
seu final. Sendo essencialmente subjetividade, esse sujeito lírico também é uma força anímica. Um corpo que absorve a manhã, tornando-se mais corpo, mas igualmente um corpo que se desintegra em luminosidade, participando da vida dos homens como uma força ativa e boa, ainda que imperceptível, contudo. Percebe-se, então, que o sentimento religioso da vida oferece inicialmente uma espécie de mediação móvel e instável entre a subjetividade lírica e o Brasil, em que o sujeito é cada vez mais e com mais força um sujeito poético reconhecível, quanto mais ele se identifica com uma vasta coletividade.

A possibilidade dessa mediação móvel é fundamentalmente uma função do tipo de verso livre utilizado. "Louvação Matinal" encontra-se na seção "Marco da Viração" do livro Remate de Males. A referência é importante, pois é nessa seção que Mário, pela primeira vez, desenvolve sistematicamente esse verso livre largo e reflexivo, capaz de abarcar a vida e o mundo em uma respiração meditativa, em que cabem entusiasmos e avaliações, confissões e reflexão, amargura e ternura. Iniciado em "Marco da Viração", esse será o verso livre transformado em versículo de "A Meditação sobre o Tietê". Entretanto, esse é um momento de experimentação, e o verso livre de "Louvação Matinal" ainda se mostra imperfeito em relação ao que será "O Rito do Irmão Pequeno" e “A Meditação sobre o Tietê”. Significativo, nesse sentido, é o fato de os dois principais interlocutores poéticos de Mário, Manuel Bandeira e Drummond, não terem gostado do poema, e por motivos semelhantes.

Bandeira escreve em carta de 04 de fevereiro de 1928:

Sobre os poemas direi, pra lhe satisfazer a vontade, que como poema só não me satisfez a "Louvação matinal", neste sentido que não me parece poesia nem verso. É uma meditação filosófica em prosa. Muito bonita, aliás. É uma linda perspectiva de pensamento num alto e tranquilo movimento rítmico de prosa. Não tem o elemento lírico da poesia; não tem o elemento musical do verso. Mas repito que é linda e que é uma boa ação: quem gosta de ler todos os dias um capítulo da Imitação (de Cristo), no dia em que ler a sua "Louvação" não precisará fazê-lo. ${ }^{276}$

Alguns anos mais tarde, ao receber o livro Remate de Males, Drummond escreve, em carta de $1^{\circ}$ de janeiro de 1931 :

Realmente não gostei da "Louvação da Tarde", apesar de incluída no "Tempo (de Maria)", como não gostei de outros poemas longos e algo palavrosos, a "Louvação matinal”, por

\footnotetext{
276 MORAES, Marco Antônio (Org.). Correspondência Mário de Andrade \& Manuel Bandeira. São Paulo: Edusp/IEB, 2001. p. 379.
} 
exemplo. Você me parece ceder por vezes à ânsia de comunicar coisas urgentes que estão passando no seu íntimo e que não são propriamente poesia. Coisas que dariam provavelmente um discurso... Em suma, você é muito universal demais para ser apenas poeta e há porções respeitáveis do seu ser que reagem contra a poesia no instante mesmo em que ela está se elaborando. Eu considero a poesia uma limitação, boa ou má não vem ao caso, e a linguagem em que é menos fácil aos homens se comunicarem, porque é a linguagem que poucos falam e mesmo esses não a possuem permanentemente. E você, alma apostólica (perdoe o adjetivo pois não acho outro), coração numerosíssimo e transbordante de humana ternura, tem tanto que comunicar aos outros! É natural que sua linguagem seja às vezes um pouco turva e inquieta. ${ }^{277}$

Como se pode ler nessas passagens, a expressão de Mário de Andrade em "Louvação Matinal” rompe os limites da elaboração estritamente poética por demandar de si algo mais imediato, mais ardente e enérgico, para além do momento de frieza necessária que a mônada poética exige da organização da linguagem. Seu apostolado por uma vida brasileira mais autêntica extrapola o poema. Essa intensidade imediata aparece no poema em dois níveis: na demanda de exemplaridade da linguagem e na demanda de exemplaridade do sujeito lírico. A segunda estrofe é o lugar mais carregado de "língua brasileira", e nele se pode entender os exageros premeditados de Mário:

Enquanto a água rija do banho me bate no corpo

Sinto a manhã se levantando viva no país...

Sinto movendo as coxas das coxilhas lá no sul;

Adiante os colonos monótonos erguem o mate,

E na sombra fraca do carijo a brisa trabalha,

Deitando sobre a congonha o bafo sedento dela;

Nos sítios de serra-acima o Solzão dependurado,

Polido e carnudo que nem fruta de jerimum,

Despenca dos itacás sangrentos e se esbandalha

Nas roças de milho, nas roças de arroz e nos corgos,

Afugentando a sombra funda das canhadas;

Nas terras de milagre as águas prenhes dos garimpos

Choram em cada bateia a lágrima dum diamante;

Mais pra arriba o grito pontudo do Cabuji

Achata o murmurejo religioso das juremas;

E quando lá no Amazonas as águas vadias se listram

Com os círculos dos jacarés que afundam pra descansar,

${ }^{277}$ SANTIAGO, Silviano (Org.). Carlos \& Mário. Correspondência de Carlos Drummond de Andrade e Mário de Andrade. Rio de Janeiro: Bem-Te-Vi, 2002. p. 401. 
Vida de trabalho brabo, vida de todo dia.

$\mathrm{E}$ as gaiolas sobem lentamente o rio,

E os passarões, de pernas esticadas,

Mergulham em reta nas nuvens morenas do céu...

(versos 5-25)

Em vinte e um versos acumulam-se quase duas dezenas de palavras e expressões brasileiras, na acepção de "brasileirismo". O leitor ainda sente aquele frescor matinal da primeira estrofe ecoando na segunda, principalmente em seus primeiros versos, que ainda mantêm a naturalidade. Em seguida, porém, o andamento fica atravancado pelo léxico, ou pouco conhecido, ou pouco usado em poesia: coxilha, mate, carijo, congonha, jerimum, itacás, ${ }^{278}$ corgos, canhada garimpo, jurema etc. A operação de Mário quer, principalmente, despertar nos demais poetas e intelectuais brasileiros o sentido da própria língua, e daí deriva conscientemente seu exagero. Contudo, o efeito acaba sendo o inverso, e o andamento truncado afasta o leitor, em vez de acolhê-lo. No momento em que o próprio Mário desenvolver suas propostas e diluir o léxico brasileiro na naturalidade poética, como nos "Poemas da Negra", "Poemas da Amiga" e "Rito do Irmão Pequeno", por exemplo, seu trabalho estará consumado e será, paradoxalmente, mais útil e exemplar. Entretanto, esse excesso que deixa a estrofe carregada revela ainda um entusiasmo e uma fé em suas pesquisas brasileiras. Elas evitam que o poema enverede pelo cabotinismo e, se deixarmos um pouco de lado a estranheza do léxico e da sonoridade, poderemos notar que a elaboração desse trecho possui grande riqueza rítmica, em versos calibrados por assonâncias de aliterações. Veja-se, como pequena amostra de uma rítmica de fôlego mais largo, esses quatro versos:

\footnotetext{
Mais pra arriba o grito pontudo do Cabuji

Achata o murmurejo religioso das juremas;

E quando lá no Amazonas as águas vadias se listram

Com os círculos dos jacarés que afundam pra descansar,
}

\footnotetext{
${ }^{278}$ Das palavras do poema, há algumas que não constam no Dicionário Houaiss (HOUAISS, Antônio; VILLAR, Mauro de Salles; FRANCO, Francisco Manoel de Mello. Dicionário Houaiss da língua portuguesa. Rio de Janeiro: Objetiva, 2007), e de duas delas não pude verificar o significado em lugar algum. São elas: "itacás" e "nombrada". "Coxilha" é um tipo de terra com pequenas e grandes elevações, em que se desenvolve atividade pastoril; "carijo" é um tipo de armação em que se secam ramos da ervamate; "congonha" é um tipo de árvore; "canhada" é um vale estreito entre montanhas; "Cabuji" se refere, provavelmente, ao Pico do Cabuji, localizado no Rio Grande do Norte; "gaiola" é um tipo de embarcação.
} 
A estridência do primeiro verso, de ritmo preponderantemente ternário e de acentos tônicos sobre as vogais "i" e "u", é distendida nos verso seguinte, de ritmo preponderantemente quaternário e de maior diversidade vocálica, mas o conjunto sonoro dos dois versos possui igualmente a constância de "r" e "j", mantendo certo tom agreste na sonoridade. A medida é mais larga nos dois versos seguintes, com maior número de sílabas, mas a rítmica é parecida, embora diversa, do par anterior: no verso "E quando lá no Amazonas as águas vadias se listram", depois do amplo "E quando lá no Amazonas", o verso retoma o ritmo ternário "as águas vadias se listram", mantendo o agudo "i" na parte final do verso. Já o último verso do trecho citado alterna o ritmo ternário com ritmos amplos, com pés de cinco e seis sílabas, ${ }^{279}$ e dividindo claramente a sonoridade entre os sons ainda agudos do "i" de "círculo" e da acentuação oxítona de “jacaré" e a sonoridade doce e repousada do "afundam pra descansar". Ao acompanhar o aproveitamento rítmico-sonoro desse trecho, percebemos que, mesmo em seu momento de maior exemplaridade, a condição de artista genuíno de Mário de Andrade ainda se mantém, dando vitalidade à sua obra e evitando que seu interesse seja somente arqueológico. E mesmo esse momento de linguagem sobrecarregada é sentido pelo poeta como necessário para se chegar a uma nova naturalidade. Ao responder a Manuel Bandeira sobre o sentimento de artificialidade que seus poemas podiam provocar, Mário afirmava:

... minha afetação. Você tem razão. Mas não posso escapar dela por enquanto porque essa afetação é psicológica. A minha naturalidade agora é a afetação porque o problema está me preocupando a todo instante e por isso me desvirtua o modo natural. Estou em época de transição. Estou criando um novo modo natural. ${ }^{280}$

Essa exemplaridade, então, não decorre de uma má-orientação poética nacionalista, da uma afirmação de liderança dentro do Modernismo ou de uma mania de grandeza de sua subjetividade artística. Antes, decorre de uma necessidade poética e humana de suas pesquisas de atitude e expressão. Mário compunha uma obra que dependia da sinceridade em relação a seus momentos e da experimentação dos recursos

\footnotetext{
${ }^{279}$ As sílabas tônicas dos versos estão em itálico. Sigo as principais sílabas tônicas “fortes”, deixando de lado as que Said Ali chama de "semiforte" (ALI, Manoel Said. Versificação portuguesa. São Paulo: Edusp, 1999. p. 35).

${ }^{280}$ MORAES, Marco Antônio (Org.). Correspondência Mário de Andrade \& Manuel Bandeira, cit., p. 183.
} 
que ia adquirindo, e, do modo como isso vem expresso, essa sinceridade tem uma essência religiosa, de demonstração dos passos de uma missão.

Houvesse um símbolo coletivo explícito a que conduzisse essa missão, fosse a anta verde-amarela, o sigma integralista, o Cristo de lastro católico-oficial ou a bandeira vermelha do estalinismo, o caminho de Mário de Andrade estaria limitado pela estreiteza rebarbativa de uma posição doutrinária. No entanto, o humanitarismo vago (embora ardente) em que se empenha esse sentimento religioso da vida impede essa decaída, embora não seja uma posição isenta de perigo. A necessidade de libertar a linguagem brasileira falada do jugo da gramática lusitana corresponde a um projeto implicitamente político de uma vida mais autêntica, mais livre. Sendo uma proposta estética e política de relevância evidente, ela, entretanto, padece da sua condição de invenção individual e de falta de correspondência coletiva. É nesse sentido que a mediação do poema não se fixa e acaba por se dissolver, pois o sujeito que demanda a coletividade fora de si - mediação entre o mesmo e o outro - acaba por reproduzir a coletividade dentro em si, fazendo a mediação desaparecer no interior da subjetividade. $\mathrm{Na}$ falta de uma mediação mais efetiva entre a missão humanitária brasileira a que Mário religiosamente se entrega e a coletividade correspondente, o poeta passa a interiorizar os elementos coletivos que acabam por a agir na interioridade do modo como o poeta gostaria que eles agissem na vida empírica. O seu resultado é uma incorporação da manhã brasileira, em uma espécie de "união mágica" do "corpo da nação" e do "corpo do poeta", que passam a existir em sintonia, e o que acontece à nação acontece ao poeta, e vice-versa. O sujeito lírico passa, então, a se sentir ilimitado, pela ausência de mediação, e a virtude da exemplaridade, a alegria matinal e a felicidade do projeto pessoal e coletivo vão encontrar formas-limite de se formalizar poeticamente. Mas essas formas-limite são um resultado do poema, e não um a priori, pois a introjeção da manhã brasileira na subjetividade lírica do poema se apresenta como um processo.

Na terceira estrofe, esse processo assume no poema uma dimensão de projeto de vida, em que a autodeterminação do sujeito e o projeto de casa possuem a forma do sonho, da "glória de ser, fazendo o que será". É um momento de doçura, próximo da forma do devaneio da "Louvação da Tarde", mas ainda enfático, com ardor matinal, na certeza de que a casa do indivíduo, a consciência de si e a comunidade da manhã brasileira se afirmarão como a felicidade do homem e da vida comum. Contudo, o 
poema adquire na sequência um movimento de ênfase cada vez maior, em que a felicidade da fé matinal vai ganhando traços normativos. Essa felicidade não se detém no sonho ou no devaneio e, não encontrando uma mediação na vida coletiva, vai se tornando eufórica. Nota-se a euforia no aumento das exclamações e das afirmações peremptórias. Uma vez tomado da euforia da própria felicidade, a virtude do eu lírico se potencializa e acaba por inebriá-lo. O sujeito ao final do poema é um inebriado da própria virtude, e na repetição exclamativa de um dos últimos versos: “É de manhã! É de manhã! A glória formidável da manhã!...”, já se sente a forma do delírio. As oscilações de uma mediação que, ao mesmo tempo, se coloca e se perde faz a subjetividade lírica assumir as formas-limite do inebriante e do delírio. São as virtudes do poeta levadas ao limite, e que, levadas às últimas consequências, chegarão ao sacrifício da própria subjetividade lírica, como veremos em "Noturno de Belo Horizonte".

Novamente, aparece aqui o elemento dionisíaco estrutural da obra de Mário de Andrade, notado pela primeira vez por Bastide e acolhido pelo próprio poeta. ${ }^{281} \mathrm{O}$ elemento dionisíaco, cumpre notar, não é um assunto ou um elemento premeditado na obra de Mário de Andrade; ao contrário, ele é uma expressão de insuficiência. Quando a sua poesia encontra um bloqueio que frearia a expansão de seu significado íntimo, seu dionisismo é ativado como um modo de sua poesia poder significar-se. É um momento em que seu sentimento religioso se casa com a expressão mítica. Observamos uma aliança efetiva, pois ambos - o mito e o sentimento religioso da vida - nascem de uma confiança no improvável, ou no impossível. É notável no poema que não é o sujeito, como se esperaria, que se dissolve na amplidão da manhã. Ao contrário, ela é internalizada pelo sujeito, numa fusão em que sujeito e manhã brasileira se tornam uma coisa só. A necessidade, em "Louvação Matinal", de fazer a vida ser mais vida do que realmente é rompe os limites da forma e da subjetividade lírica: o poema vira oração, o sujeito entra em delírio. O delírio é uma forma-limite de uma subjetividade sem limite.

A essa altura da análise, o poema cria uma ponte para temas fundamentais da obra poética de Mário de Andrade que não estão explícitos nele, mas que podem ser pensados a partir dele. Desse modo, a felicidade e a entrega à vida, aparecendo em "Louvação Matinal” em sua faceta de oração matinal, de uma felicidade e de uma vida

\footnotetext{
281 “... a constância coreográfico-dionisíaca que atravessa toda a minha poesia, e pra qual o Roger Bastide já chamou a atenção" (ANDRADE, Mário de. A Carlos Lacerda. In: PAES, José Paulo. Sobre "O Carro da Miséria”. Revista do Instituto de Estudos Brasileiros, n. 36. São Paulo: IEB, 1994. p. 181-182).
} 
virtuosa cuja euforia chega ao paroxismo do delírio, podem ser também analisadas em seus pressupostos, que podem não ser imediatamente visíveis no poema, mas que fazem parte da função da crítica no pensamento estético. ${ }^{282}$ A felicidade defendida por Mário de Andrade em sua obra não nasce da propaganda de uma vida pacífica e risonha, naturalmente feliz. Ao contrário, sua felicidade é fundamentalmente uma solução de problemas muito graves da subjetividade empírica do homem e poética do poeta. Sua felicidade, pode-se dizer, é uma dolorosa e eufórica entrega a um ideal de felicidade comum para todos os homens, nascido de uma vida pessoal profundamente infeliz. Sua felicidade é uma resposta do seu valor humano a uma vida danificada. Os danos que sua vida acumulou são tanto de origem pessoal quanto social. De foro mais íntimo, citem-se o sofrimento por ser mulato no mundo dos brancos, bem como de reconhecida feiúra quando criança e jovem, e o sofrimento pela sua tendência à homossexualidade e, por consequência, pela impossibilidade do seu reconhecimento público. São sofrimentos íntimos, mas que não impediram o moço de boa família de se colocar bem na sociedade, tornando-se professor vitalício do Conservatório Musical. A aceitação de uma vida convencional na mediocridade burguesa certamente afastaria esses sofrimentos no torpor das alegrias rotineiras de uma vida de amigos, dinheiro e família. Aos sofrimentos pessoais deve-se somar a morte do irmão mais novo, Renato, de profundas repercussões em sua vida íntima, causando-lhe tremor nas mãos e impedindo sua aspiração a virtuose de piano. ${ }^{283}$ Uma subjetividade fragilizada, mas de vibrante energia intelectual, que começa a se interessar pela atualidade das artes da Europa. Aqui começam as agruras mais sociais do poeta. Sua família o toma por esquisito pelas suas opiniões modernas, e Oswald de Andrade o lança no olho do furacão ao publicar em jornal alguns de seus poemas modernistas (chamados de "futuristas", então), que tornarão o poeta motivo de chacota generalizada. Devem-se lembrar as dimensões provincianas da vida social da São Paulo de então, cidade à época mais próxima do sabe-se-de-tudo das cidades do interior do que do anonimato e das possibilidades de independência pessoal de uma metrópole moderna (embora São Paulo aspirasse cada vez mais se transformar, por vias contraditórias, em metrópole moderna...). É conhecido o transe de sofrimento acumulado que gerou os poemas Paulicéia desvairada, causado

\footnotetext{
${ }^{282}$ Ver ADORNO, Theodor W. Necessidade da Estética. Teoria estética. Lisboa: Edições 70, 2008.

${ }^{283}$ CASTRO, Moacir Werneck de. Mário de Andrade: exílio no Rio. Rio de Janeiro: Rocco, 1989. p. 57.
} 
pela aquisição de uma escultura moderna de Brecheret. ${ }^{284}$ Acrescente-se que, ao contrário de Oswald, que não apenas não sofria como incentivava e gozava a difamação de que era alvo, Mário vivia profundamente a vida das pessoas ao seu redor e padecia com a incompreensão de próximos e distantes. A Semana de Arte Moderna não só disseminou ainda mais as chacotas e recriminações públicas mas também levou o poeta à bancarrota, pois ele perdeu todos os alunos particulares de piano, e só não foi demitido do Conservatório porque o seu cargo era vitalício. Compensações havia, porém, e não somente Mário era amparado por famílias paulistanas de prestígio como tornou-se uma referência para os artistas modernizantes, primeiro de São Paulo, depois de quase todas as partes Brasil. Com isso, Mário armou a solução de sua vida que durou o restante da década de 1920: o dilaceramento do sofrimento pessoal era superado e sublimado na felicidade da entrega de sua obra e de seu "ser", como ele falava, para a coletividade brasileira, com a qual ele contribuía com sua obra artística, intelectual e com seu exemplo humano de entrega. O sofrimento organizado e disposto como virtude e exemplo fazia com que as coisas adquirissem sentido, mesmo a dor, que a passava a ser elemento necessário na expressão da totalidade da vida a que ela se entregava, por isso seu refrão: "A própria dor é uma felicidade”, que aparece pela primeira vez em Losango cáqui, "XVII", e reaparece em "Rito do Irmão Pequeno". O drama de sua solução pessoal, cuja sinceridade se fundava no elemento religioso de entrega virtuosa à vida que por sua vez dependia da sinceridade para registrar os passos de sua missão - foi a falta de correspondência da vida coletiva. E, em vez da "insuficiência da vontade diante de um alvo desvirtuado", de que fala Roberto Schwarz ${ }^{285}$ na avaliação dos grandes projetos à brasileira, a disposição religiosa de Mário redobrou a vontade, potenciando poeticamente sua expressão, mas igualmente incorporando as insuficiências da vida

\footnotetext{
${ }^{284}$ Ao adquirir a "Cabeça de Cristo", que Brecheret o concedera passar em bronze, Mário chega em casa com seu "Cristo de trancinha", muito feliz. No entanto, a família se escandaliza e começa a ralhar violentamente com o poeta. $\mathrm{O}$ resultado pode ser acompanhado nas palavras do próprio poeta: "Fiquei alucinado, palavra de honra. Minha vontade era bater. Jantei por dentro, num estado inimaginável de estraçalho. Depois subi para o meu quarto, era noitinha, na intenção de me arranjar, sair, espairecer um bocado, botar uma bomba no centro do mundo. Me lembro que cheguei à sacada, olhando sem ver o meu largo. Ruídos, luzes, falas abertas subindo dos choferes de aluguel. Eu estava aparentemente calmo, como que indestinado. Não sei o que me deu. Fui até a escrivaninha, abri um caderno, escrevi o título em que jamais pensara, 'Paulicéia Desvairada'. O estouro chegara afinal, depois de quase ano de angústias interrogativas. Entre desgostos, trabalhos urgentes, dívidas, brigas, em pouco mais de uma semana estava jogado no papel um canto bárbaro, duas vezes maior do que isso que o trabalho de arte deu num livro" (ANDRADE, Mário de. O Movimento Modernista [1942]. Aspectos da literatura brasileira. Belo Horizonte: Itatiaia, 2002. p. 256).

285 "... a insuficiência da vontade diante de um alvo desvirtuado, eis aí uma configuração muito nacional, com fundamento histórico profundo" (SCHWARZ, Roberto. Um mestre na periferia do capitalismo. São Paulo: Duas Cidades/Editora 34, 2001.p. 204).
} 
danificada, agora da vida coletiva, que levavam sua obra ao excesso de ênfase e às situações-limite da subjetividade.

"Louvação Matinal" é o documento auroral dessa solução, em que os sofrimentos estão de certa forma exorcizados pela luminosidade do dia e pela manhã coletiva que se levanta. A incorrespondência da vida coletiva é apenas pressentida, e o poema-oração supõe, pela sua própria força religiosa, poder criar, colocando-se na situação-limite da virtude que inebria, uma felicidade que é uma fusão de subjetividade lírica e coletividade brasileira no interior do eu lírico e da linguagem do poema. Os trabalhos que começam de manhã são colhidos ao fim do dia, e à tarde o poeta retoma seu livro das horas.

\section{Breviário Laico: II. Tarde}

No poema "Louvação da Tarde", também de Remate de Males, é a natureza especificamente religiosa da tarde que determina sua fina arquitetura. Os versos iniciais já imergem o leitor em um mundo dominado por esse momento do dia:

\footnotetext{
Tarde incomensurável, tarde vasta,

Filha de Sol já velho, filha doente

De quem despreza as normas da Eugenia,

Tarde vazia, dum rosado pálido,

Tarde tardonha e sobretudo tarde

Imóvel... quase imóvel
}

(versos 1-6)

Em um primeiro momento, podemos destacar as características dessa tarde, que se expande verso a verso ocupando todo o trecho inicial do poema como fenômeno da natureza, mas igualmente como presença personificada. Antonio Candido notou principalmente as características "curiosas" dessa personificação, como o fato de ela ser "filha enfermiça de velho", lerda, e ironizar a eugenia, pseudociência tão em voga no Brasil da época. Essa irreverência inicial dos versos levou o crítico a falar no tom de “amena brincadeira” com que o poema se abre. ${ }^{286}$ À amena brincadeira, contudo, somam-se características de uma presença não antropomórfica e igualmente

\footnotetext{
${ }^{286}$ CANDIDO, Antonio. O poeta itinerante. O discurso e a cidade. São Paulo: Duas Cidades, 1998. p. 268.
} 
significativa. A tarde é: incomensurável, vasta, vazia, tardonha, imóvel (quase imóvel). A "filha de Sol já velho, filha doente" guarda certa graça lúdica, mas o espaço que ela ocupa possui uma arquitetura solene. A presença vasta e vazia, de quase imobilidade, que parece deter por um instante o fluxo da vida, tem algo do espaço de uma catedral. Catedral na natureza, solenidade que convive com a irreverência, nesse espaço a vida é a um tempo a vida comum, de qualquer homem poroso à tarde, e uma vida sacralizada pelo espaço em que adentra. Note-se que o modo como um fenômeno do tempo adquire de tal forma uma presença e quase imobilidade, que se torna um fenômeno do espaço. Em uma das principais fontes de "Louvação da Tarde", a poesia de Wordsworth, ${ }^{287}$ há, dentre seus poemas sobre a tarde, um de título "Composed upon an Evening of Extraordinary Splendour and Beauty", que chama a atenção não pelo ritmo, pois trata-se de um poema de versos octossílabos de dísticos rimados, e não do decassílabo branco, mas pelo modo como elabora o simbolismo e a significação da tarde, em que a transformação do tempo em espaço dá à tarde uma solenidade que a sacraliza. Diz Wordsworth que, caso a tarde passasse rápido, o poeta apenas lançaria um olhar atônito sobre a passagem do dia à noite:

But 'tis endued with power to stay,

And sanctify one closing day,

That frail Mortality can see -

What is? - ah, no, but what can be! ${ }^{288}$

Parte I (versos 5-8)

Como se pode ler nesses versos, a tarde de matriz romântica instaura um espaço sagrado, e nesse espaço a subjetividade poética pode entregar-se à visão das coisas que

\footnotetext{
${ }^{287}$ Em carta a Bandeira de 12 de dezembro de 1925, Mário fala sobre a construção e as influências de "Louvação da Tarde": "O poema poesia construído com o pensamento condicionando o lirismo que tem de ser enorme (senão não transparece) o mais formidável que puder porém duma ardência como que escondida porque inteiramente interior. Enfim: o poema inglês. Shelley, Keats, Wordsworth, Swinburne, Yeats, dessa gente" (MORAES, Marco Antônio (Org.). Correspondência Mário de Andrade \& Manuel Bandeira, cit., p. 262). Sobre a preponderância da influência de Wordsworth em relação aos outros poetas ingleses, deve-se acrescentar, além da proximidade natural entre o tom meditativo específico de Wordsworth e o desse poema, os comentários de Antonio Candido, que o destaca como influência entre os românticos ingleses (CANDIDO, Antonio. O poeta itinerante, cit., p. 261-262), e ainda o comentário de Gilda de Mello e Souza sobre "Louvação da Tarde": "Lendo esses admiráveis decassílabos brancos, pensamos quase insensivelmente em alguns dos nossos poetas do passado e nos poetas ingleses "dos lagos', sobretudo Wordsworth, aos quais Mário se refere implicitamente na simples adoção desse tipo de poema" [grifo meu] (SOUZA, Gilda de Mello e. A poesia de Mário de Andrade. O tupi e o alaúde (1979). São Paulo: Duas Cidades/Editora 34, 2003. p. 30).

${ }^{288}$ Grifo do original.
} 
podem ser. Pois a tarde também tem outra função, a de separar o sujeito de sua vida imediata, para abrir o espaço ao devaneio e ao sonho, pressupostos dessa visão de uma vida mais plena e de um mundo mais justo. Nessa função, o que observamos é um distanciamento do eu lírico em relação às determinações e necessidades da vida e do mundo:

\section{Só tu me desagregas tarde vasta \\ Da minha trabalhadeira. Sigo livre \\ Deslembrado da vida, lentamente}

(versos 11-13)

Esse distanciamento, observado internamente como elemento estrutural do poema, como uma função da tarde na subjetividade poética, opera, no entanto, significações dentro e fora do poema, sendo igualmente estrutural na relação do poema com o conjunto da obra poética mariodeandradiana.

Em primeiro lugar, "Louvação da Tarde" ocupa na obra poética de Mário um momento de parada. A euforia e o sofrimento que vinham de 1922, que neste e nos anos seguintes resultaram em um processo criativo e elaborador incansável, tem seu primeiro momento de refluxo em 1925, data da primeira redação do poema, retocado para a publicação no "Ciclo de Maria", de Remate de Males (1930). Esse refluxo vai imprimir-se na expressão da subjetividade lírica e no modo de lidar com as formas poéticas. Um sentimento de elevação, de maturidade, que pode, como em certo momento vai, encaminhar-se para a indiferença elevada cujo resultado maior será a composição dos "Poemas da Negra" e "Poemas da Amiga", e na preguiça organizada de "Rito do Irmão Pequeno". Mas aqui o sentimento de elevação está recém-maturado, ainda imbuído da energia empenhada no pragmatismo nacional e no sentimento religioso da vida, muito ativos e implicados mutuamente na década de 1920. A elevação em seu primeiro momento, então, tem de ser disciplinada pela sugestão da imersão na tarde e pela forma meditativa. Essa posição da subjetividade encontra sua forma mais adequada no poema meditativo romântico, feito de decassílabos brancos. Esse momento de sua obra poética, como aliás ela toda, diga-se de passagem, pode ser acompanhada na correspondência com Manuel Bandeira. Aí, em carta de 12 de dezembro de 1925, Mário diz querer fazer: “O poema poesia construído com pensamento condicionando o lirismo que tem de ser enorme (senão não transparece) o mais formidável que puder porém 
duma ardência como que escondida porque inteiramente interior". ${ }^{289}$ A adoção da forma consagrada obedece a necessidades profundas do momento expressivo e da evolução da subjetividade poética de Mário de Andrade. Trata-se de disciplinar o lirismo em um momento de refluxo do combate literário, de um novo momento de elevação e maturidade. Sua escolha se pauta por necessidades internas de expressão de sua obra poética e das premissas mariodeandradianas de sinceridade e destino, de que decorre a lógica estrita da organização de sua obra poética.

Desse modo, a tarde que abre os versos de "Louvação da Tarde" é o correlato poético da primeira tarde realmente sentida pelo poeta em sua atividade poética. E do distanciamento que a tarde gera, desse ardente lirismo interior, disciplinado pelo pensamento, decorre a adequação da escolha, a forma romântica. A prova disso é a naturalidade contínua da dicção, a ausência da sensação de artifício, que agradou mesmo um Manuel Bandeira pouco simpático ao decassílabo branco romântico. ${ }^{290}$

Para expressar a disciplina do pensamento, Mário lançou mão de um expediente novo, ao que tudo indica uma invenção sua na história da poesia moderna: ${ }^{291}$ o passeio meditativo feito de carro. Um "forde" passeia entre a natureza e os decassílabos brancos. Contudo, sem qualquer elogio futurista à máquina, ela, a "maquininha", é harmonizada com a natureza:

O doce respirar do forde se une

Aos gritos ponteagudos das graúnas,

(versos 20-21)

E os versos seguintes tornam explícita a função disciplinadora da máquina:

Aplacando meu sangue e meu ofego.

São murmúrios severos repetidos

Que me organizam todo o ser vibrante

Num método sadio. Só no exílio

\footnotetext{
${ }^{289}$ MORAES, Marco Antônio (Org.). Correspondência Mário de Andrade \& Manuel Bandeira, cit., p. 262.

${ }^{290}$ MORAES, Marco Antônio (Org.). Correspondência Mário de Andrade \& Manuel Bandeira, cit., p. 226.

${ }^{291}$ CANDIDO, Antonio. O poeta itinerante, cit., p. 265-267, que acompanho de perto nesse momento da exposição.
} 
Do seu silêncio os ritmos maquinares

Sinto metodizando, regulando

O meu corpo. E talvez meu pensamento...

(versos 23-29)

Antonio Candido notou a sutileza harmonizadora do neologismo "maquinares", que funde em uma palavra o elemento maquinal do radical morfológico da palavra e o elemento natural do morfema "-ares", analógico a "cavalares", "muares". ${ }^{292}$ A disciplina sobre o lirismo vai atuar num sentido mais profundo na composição do poema, revelando um momento excepcional da obra poética de Mário, pois, com essa disciplina, o poema vai abrir-se para o devaneio intelectualmente controlado, para o sonho dirigido:

Tarde macia, pra falar verdade:

Não te amo mais do que a manhã, mas amo

Tuas formas incertas e estas cores

Que te maquilham o carão sereno.

Não te prefiro ao dia em que me agito,

Porém contigo é que imagino e escrevo

$\mathrm{O}$ rodapé do meu sonhar, romance

Em que o Joaquim Bentinho dos desejos

Mente, mente, remente impávido essa

Mentirada gentil do que me falta.

Um despropósito de perfeições

Me cerca, e em grata sucessão de casos,

Vou com elas vivendo uma outra vida:

(versos 46-58)

Trecho fundamental do poema, em que a tarde fecha a sua função de sagração e distanciamento, que passam a funcionar sob a direção do sonho. ${ }^{293} \mathrm{O}$ momento único e excepcional desse poema na obra poética de Mário se deve ao fato de ele ser um devaneio controlado, um sonho dirigido. Ora, em uma obra cuja constante estrutural é o dionisíaco, surpreende essa aparição de um momento apolíneo. Nietzsche, que reviveu

\footnotetext{
${ }^{292}$ CANDIDO, Antonio. O poeta itinerante, cit., p. 266-267.

293 Joaquim Bentinho: "personagem caipira de Cornélio Pires, o mentiroso monumental do livro Estrambóticas aventuras de Joaquim Bentinho, o queima campo (1925)" (CANDIDO, Antonio. O poeta itinerante, cit., p. 271).
} 
na modernidade o significado desses dois deuses da arte grega, afirma: "Eis o verdadeiro desígnio artístico de Apolo: sob o seu nome reunimos todas aquelas inumeráveis ilusões da bela aparência que, a cada instante, tornam de algum modo a existência digna de ser vivida e impelem a viver o momento seguinte". ${ }^{294}$ O medium dessas inumeráveis ilusões de bela aparência é o sonho: "Eis o estado apolíneo de sonho, no qual o mundo do dia fica velado, e um novo mundo, mais claro, mais compreensível, mais comovedor do que o outro e, no entanto, mais ensombrecido, em incessante mudança, nasce de novo aos nossos olhos". ${ }^{295}$ Contrariamente à embriaguez dionisíaca, que vimos em "Louvação Matinal" e que reaparecerá em "Noturno de Belo Horizonte", é sob o signo do sonho apolíneo que "Louvação da Tarde" se estrutura.

Esse sonho apolíneo vai se desenvolver em três temas, que ocupam três momentos consecutivos no poema: o sonho da saúde e do amor realizado (versos 5991); o sonho das viagens e do conhecimento do Brasil (versos 92-113); e o sonho de uma vida materialmente abastada (versos 116-135). Em todos os temas, o sonho adquire feição brasileira. No primeiro tema, da saúde e do amor realizado, mais brasileiro do que as "específicas doenças paulistanas" é a disposição amorosa do eu lírico, ${ }^{296}$ em que a renúncia amorosa tem implicações de classe e sobrepõe as implicações cívicas dos amorosos ao potencial de arrebatamento do amor paixão. É um tópico do ciclo "Tempo de Maria”, que já vimos. Deixarei o segundo tema por último, pois ele é central nesta análise. O terceiro tema tem de brasileiro o que já apontou Antonio Candido sobre a prosperidade material que o poeta almeja, é a "prosperidade econômica expressa nos termos paulistas dos anos Vinte, com base na lavoura do café e na pecuária do civilizado gado caracu". ${ }^{297}$ A saúde, o amor e a prosperidade aparecem no sonho dirigido não como deveriam ser na realidade, caso o poeta pudesse moldar o mundo à sua feição, antes aparecem como aquilo que, habitando o momento do devaneio, deixa escoar o excesso de vida do poeta, criando uma ilusão ativa, que, uma vez terminada, revitaliza o poeta para a sua felicidade, para "dirigir sarado a concordância da vida com o meu destino". É um modo de a poesia mais subjetiva atuar na consecução de seu pragmatismo nacional.

\footnotetext{
${ }^{294}$ NIETZCHE, Friedrich. O nascimento da tragédia ou helenismo e pessimismo. São Paulo: Companhia das Letras, 2007. p. 141.

${ }^{295}$ NIETZCHE, Friedrich. O nascimento da tragédia ou helenismo e pessimismo, cit., p. 59.

296 Questão estudada no Capítulo III, no tópico "Renúncia".

${ }^{297}$ CANDIDO, Antonio. O poeta itinerante, cit., p. 274.
} 
Os modos de plenitude da vida subjetiva - saúde, amor, riqueza - são iluminados exemplarmente pela disposição apolínea. Criam a bela aparência, fazem a vida parecer digna de ser vivida. O sonho cumpre a sua função no equilíbrio necessário a uma vida ativa. Porém, há um tema ao qual a bela aparência parece furtar-se, criando uma fissura no equilíbrio apolíneo. Esse tema é o Brasil. Os temas anteriores são elaborados no sonho pelo acréscimo imaginário ao que a realidade nega, mas todos são compostos de elementos existentes no mundo, passíveis de a imaginação compor como plenitude. Contudo, o conhecimento do Brasil não é levado pelo sonho dirigido a uma plenitude que derive da organização imaginária de um potencial existente. É necessário reproduzir o trecho:

Livre dos piuns das doenças amolantes,

Com dinheiro sobrando organizava

As poucas viagens que desejo... Iria

Viajar todo esse Mato Grosso grosso,

Danado guardador da indiada feia,

E o Paraná verdinho... Ara, si acaso

Tivesse imaginado no que dava

A Isidora, não vê que ficaria

$\mathrm{Na}$ expectativa pança em que fiquei!

Revoltoso banzando em viagens tontas

Ao menos o meu sul conheceria,

Pampas forraginosos do Rio Grande

E praias ondejantes do Iguaçu...

Tarde, com os cobres feitos do teu ouro,

Paguei subir pelo Amazonas... Mundos

Desbarrancando, chãos desbarrancados,

Aonde no quiriri no mato brabo

A terra em formação devora os homens...

Este refrão dos meus sentidos... Nada

Matutarei mais sem medida, oh tarde,

Do que esta pátria tão despatriada! ${ }^{298}$

(versos 92-112)

\footnotetext{
${ }^{298}$ Pium é sinônimo de borrachudo; Isidora é outro nome para a Coluna Prestes, baseada no nome de um dos seus líderes, o general Isidoro Dias; quiriri é palavra tupi que significa silêncio.
} 
"Sem medida"... Aparece uma fissura na plenitude apolínea, e, como consequência lógica, o dionisíaco desponta no começo da estrofe seguinte, prontamente abafado:

\author{
Vibro! Vibro! Mas constatar sossega \\ A gente. Pronto sosseguei.
}

(versos 113-114)

Assim, o "forde" retoma o caminho de volta, e o poeta começa o sonho de prosperidade sem fechar o sonho da nação. Notável é que novamente o elemento dionisíaco surge em um momento crítico. Enquanto o sonho se dirige pelas regiões a conhecer, ele se mantém como posição apolínea do espírito, com a bela aparência se moldando na medida em que a imagem se mostra. Enquanto Centro-Oeste e Sul povoam a imaginação do poeta, não há crise. Esta aparece quando o poeta vai recompor a experiência vivida. O rio Amazonas tem na obra de Mário a conotação da "civilização ideal" brasileira. ${ }^{299}$ Entretanto, o cenário da civilização ideal, que fecharia no sonho o círculo começado no Oeste, passando pelo Sul e fechando no Norte, se mostra convulso. "A terra em formação devora os homens", a terra não é ainda humanizada, o homem não apenas não lhe deu feição como é devorado por uma terra, que devora tanto ele quanto a si mesmo. O Brasil não somente é incompleto como também se nega a completar-se no sonho dirigido apolíneo. O sonho não basta, o Brasil é um enigma, seria preciso resolver a quadratura do círculo. Por isso, sem se completar, o Brasil vira tema recorrente e insistente de meditação. $\mathrm{O}$ aspecto de teimosia pode ser observado na escolha da palavra, o "matutar", que deriva de "matuto" e guarda as conotações de ignorante e desconfiado, mas teimoso em querer saber o que não consegue.

O momento de impulsão dionisíaca no poema é um parêntesis, da maior importância, mas um parêntesis, pois no poema não é pelo matutar que o Brasil será solucionado. A união de subjetividade e nação na linguagem do poema, mediada pela tarde e pelo sonho dirigido apolíneo, vai solucionar a questão pelo elemento religioso. A

\footnotetext{
${ }^{299}$ Como ele expõe in loco: "Por enquanto, o que mais me parece é que tanto a natureza como a vida destes lugares foram feitos muito às pressas, com excesso de castroalves. E esta pré-noção invencível, mas invencível, de que o Brasil, em vez de se utilizar da África e da Índia que teve em si, desperdiçou-as, enfeitando com elas apenas a sua fisionomia, suas epidermes, sambas, maracatus, trajes, cores, vocabulários, quitutes... E deixou-se ficar, por dentro, justamente naquilo que, pelo clima, pela raça, alimentação, tudo, não poderá nunca ser, mas apenas macaquear, a Europa. Nos orgulhamos de ser o único grande (grande?) país civilizado tropical... Isso é o nosso defeito, a nossa impotência. Devíamos pensar, sentir, como indianos, chins, gente de Benin, de Java... Talvez então pudéssemos criar cultura e civilização próprias. Pelo menos seríamos mais nós, tenho certeza" (ANDRADE, Mário de. O turista aprendiz. Belo Horizonte: Itatiaia, 2002. p. 60).
} 
"mentirada gentil do que me falta" neste poema não é um fim em si mesmo, mas um caminho. Com a mentirada gentil propiciada pela tarde, e sua condescendência puxapuxa, o poeta escoa o excesso de vitalidade. Esse escoamento do excesso na tarde gera uma revitalização do espírito. Em termos religiosos, o que se opera é um "segundo nascimento". Novamente e pela última vez, é o poema já citado de Wordsworth que deixa mais explícito o que no poema de Mário está mais ou menos implícito:

My soul, though yet confined to earth,

Rejoices in a second birth!

Parte IV (versos 17-18)

A função da tarde e a função do sonho apolíneo é a purificação do sujeito lírico, nessa religiosidade laica que estamos seguindo na poesia de Mário de Andrade. O êxtase do dia e o delírio matinal da virtude chegam na tarde carregados dos trabalhos do dia, de combates, de trabalhos vários, de discussões em várias direções. O dia chega nesse momento religioso da tarde carregado das impurezas da vida diária do homem ativo, do sujeito lírico empenhado no pragmatismo nacional. $\mathrm{Na}$ tarde, como pudemos acompanhar, há um ritual de distanciamento, de sonho dirigido, que, juntos, operam a purificação da subjetividade lírica. Essa purificação é simbolicamente um "segundo nascimento" do sujeito lírico, incensado e renovado. É com essa subjetividade lírica limpa que o poeta sai da tarde e entra na noite.

\section{Breviário Laico: III. Noite}

Por fim, com a chegada da noite, entramos no "Noturno de Belo Horizonte", poema de Clã do jabuti. ${ }^{300}$ Logo de início, na leitura dos dois primeiros versos, pode-se perceber a natureza da noite que habita o poema:

Maravilha de milhares de brilhos vidrilhos,

Calma do noturno de Belo Horizonte...

300 Publicado anteriormente na revista Estética n. 3 (1925). Os três volumes dessa revista foram republicados em edição fac-similar: Estética 1924/1925. Rio de Janeiro: Gernasa, 1974. 
O primeiro verso é uma explosão de sonoridades, de "r" e "lh" que se repetem, criando um clima de festa. Não se sabe se os brilhos são das luzes da cidade, do céu estrelado ou de alguma propriedade sobrenatural da noite, produtora de "maravilhas". Porém, em vez de sabermos de onde vêm tantas luzes, o verso seguinte nos puxa para a calma e a sensação de silêncio de uma noite vasta e vazia. É quase um verso triste de poema melancólico... Contudo, o poema será construído na mais necessária interdependência dessas duas situações poéticas: os milhares de brilhos e a solidão mais isolada do sujeito lírico. É nesse contexto que a noite, separada de acontecimentos empíricos, de circunstâncias humanas, pode dar seu rendimento mais genuíno. A noite aqui não é cenário onde coisas acontecem, ela é o próprio acontecimento, pois a noite, tal como sedimentada na memória popular e na mitologia clássica, é o espaço que faz a intersecção do nosso mundo com o universo de "seres estranhos e poderosos". Novamente, como em "Louvação da Tarde", o tempo é mudado em espaço, o que evoca a presença do sagrado. Segundo o Dicionário do folclore brasileiro, de Câmara Cascudo, a noite:

Mantém no espírito popular sua impressão de mistério. Para as populações do interior do Brasil, as horas da treva são sinistras, e o mundo se povoa de seres estranhos e poderosos. Muitas tradições clássicas da Grécia são correntes, assimiladas nas versões cristãs. A mais conhecida é que não se devem pronunciar nomes malditos, nem praguejar, porque acontece o que se sugeriu, e o diabo ocorre ao chamamento, pois é seu domínio a noite escura. [...] O respeito que os gregos e os romanos tinham pela Noite, filha do Caos, irmã e esposa de Érebo, era complexo e cheio de minúcias e cerimônias. As entidades terríveis de infinito poder tinham nascido da Noite, e algumas sem união carnal, como Moira (o Destino), Átropos (morte), Hipnos (sono), os Sonhos, Momo, a Miséria, as três parcas, as Hespérides, Nêmesis, Apaté (a fraude), a Connoite. [...] Como em qualquer parte do mundo, durante a noite, aparecem os fantasmas, almas do outro mundo, luzes espantosas, gritos, gemidos, penitências estranhas, animais fabulosos, todo o cortejo apavorante, que vive nas trevas da noite. ${ }^{301}$

A citação tem de ser necessariamente longa, pois é amplamente explicativa dos significados que a noite adquire no poema de Mário: universalmente simbólica, ela é a porta de entrada de mundos estranhos e fabulosos, de conjurações feitas pela pronúncia de palavras e espaço de rituais de transformação mágica. Por isso, a ausência de acontecimentos circunstanciais no poema torna a noite algo mais substancial em seu

${ }^{301}$ CASCUDO, Câmara. Dicionário do folclore brasileiro. Rio de Janeiro: Ediouro, s/d. p. 615. 
poder simbólico, e a sequência da primeira estrofe, começada pelos versos já citados, produz esse afastamento da empiria do espaço do poema:

O silêncio fresco desfolha as árvores

E orvalha o jardim só.

Larguezas.

Enormes coágulos de sombra.

O polícia entre rosas...

Onde não é preciso, como sempre...

Há uma ausência de crimes

Na jovialidade infantil do friozinho.

Ninguém.

O monstro desapareceu.

Só as árvores árvores do mato-virgem

Pendurando a tapeçaria das ramagens

Nos braços cabindas da noite.

(versos 3-15)

Note-se como o policial deslocado, o "polícia", é afastado do poema: "o monstro desapareceu". Outro afastamento mais discreto ocorre na passagem: "Há uma ausência de crimes/Na jovialidade infantil do friozinho", que dialoga com o poema "Noturno", de Paulicéia desvairada, cujo verso inicial é "Luzes do Cambuci pelas noites de crime...". O poeta está afastando essa noite agitada, cheia de pessoas e desejos eróticos da metrópole real. Tanto a noite simbólica quanto o sujeito lírico neste início de poema estão substancialmente puros, pois só assim eles vão ativar suas potencialidades profundas.

Os três versos finais dessa primeira estrofe, cujo ritmo de versos livres entrecortados compõe o ritmo ao mesmo tempo calmo e festivo, são um dos pontos altos de alcance poético do Mário de Andrade do começo dos anos 1920, bem como do primeiro Modernismo de um modo geral. No poema, sua função é fechar a apresentação da noite na primeira estrofe, com a eliminação de todo o circunstancial, inclusive a malha urbana, em um percurso ascendente, do mato e das arvores através de sua ramagem até a mais escura noite. Mas a precisão na escolha das palavras e das imagens poéticas dá a essa passagem a feição de culminação de um ideal poético, e faz a ponte da análise interna do poema para a sua significação histórica dentro da poesia 
modernista. Destaco principalmente o verso final "Nos braços cabindas da noite", 302 com seu acento forte na palavra de origem africana, de uso coloquial no nordeste brasileiro. A imagem de acolhimento e a sonoridade forte dão a expressão ao mesmo tempo brasileira e poética ao verso. O aproveitamento das sugestões poéticas da pele negra, que aparecerão de novo nos "Poemas da Negra", criam aqui uma imagem mítica e acolhedora, de uma noite noturna, pesada e escura, e, no entanto, acolhedora. Pela função que exerce no poema, fechando um andamento inicial, em um poema ambicioso e de grande significação - elemento interno que amplifica a significação do verso -, talvez se possa dizer que este é o mais perfeito dos versos "brasileiros" da obra poética de Mário nos anos 1920.

A força poética desse verso, uma espécie de resumo da manifestação poderosa do poema, pode ser lida, nesse momento de minha análise, como um índice da impressão causada pelo poema em poetas como Manuel Bandeira e Carlos Drummond de Andrade. Antes, entretanto, essa passagem poética reverbera outro diálogo, interno ao Modernismo de São Paulo. O emprego da expressão "mato-virgem" aponta para o debate com Tarsila do Amaral e Oswald de Andrade nessa época. ${ }^{303}$ Esse longo poema de Mário de Andrade, com mais de 400 versos, foi composto em 1924, publicado na revista Estética n. 3 em 1925 e recolhido, praticamente sem modificações, no livro Clã do jabuti, de 1927. Um pouco antes de sua composição, em 1923, Mário de Andrade escreve em carta a Tarsila de Amaral, então em Paris com Oswald, ambos tomando contato e lições com a vanguarda francesa, principalmente o cubismo: “Abandona Paris! Tarsila! Tarsila! Vem para a mata-virgem, onde não há arte negra, onde não há também arroios gentis. Há MATA VIRGEM. Criei o matavirginismo. Sou matavirgista. Disso é que o mundo, a arte, o Brasil e minha queridíssima Tarsila precisam". 304 O crítico Vinícius Dantas, em texto específico sobre esse diálogo a três, chamado "Entre 'A Negra' e a Mata Virgem", estuda em detalhe o modo como se deu esse diálogo, com suas implicações de classe e posição dentro do Modernismo. O objetivo de Dantas é a

\footnotetext{
${ }^{302}$ Cabinda: "Dizem cambinda no Brasil, região ao norte de Angola, entre o rio Zaire [...] e o Atlântico. É de vastíssimo prestígio o vocábulo no Nordeste brasileiro. Cabinda, sambinda, talqualmente Congo e Guiné, foi sinônimo do escravo africano. Cambindas eram também denominados os grupos dançantes de negros que folgavam pelo Recife em préstito, até a porta da Matriz, depois convergindo, funcionalmente, para o Carnaval, no ritmo solene dos desfiles fascinantes dos maracatus" (CASCUDO, Câmara. Dicionário do folclore brasileiro, cit., p. 209).

${ }^{303}$ Debate que é exposto, comentado e interpretado em seus resultados por DANTAS, Vinícius. Entre "A Negra" e a Mata Virgem. Novos estudos. São Paulo, n. 45, jul.1996.

${ }^{304}$ Carta de 13 de outubro de 1923 (AMARAL, Aracy (Org.). Correspondência Mário de Andrade \& Tarsila do Amaral. São Paulo: Edusp/IEB, 2001. p. 79).
} 
revisão crítica da obra de Oswald, e o seu ponto de chegada é a percepção de que a formulação da "poesia pau-brasil" é fruto de um esforço coletivo desses três artistas, interpretado e formulado especificamente por Oswald. ${ }^{305}$ Duas coisas interessam nessa discussão quando olhadas pelo lado mariodeandradiano: a recuperação da expressão "mata virgem" nesse poema ambicioso e a imagem da negra no último verso da primeira estrofe. Procurei cruzar as datas e as referências ao quadro de Tarsila e do poema de Mário, para ver se houve interinfluência entre eles. Tarsila pinta "A Negra" em 1923, em Paris, mas os únicos quadros dessa temporada (1923-1925/1926) a que Mário tem acesso são de Léger e Picasso, que ele compra por intermédio de Tarsila. O que Mário pede, em 7 de janeiro de 1925, é um livrinho de poemas de Cendrars, que Tarsila está ilustrando. Esse livrinho, chamado Le formose, tem o desenho na capa de "A Negra". Porém, em correspondência com Bandeira, Mário anuncia em 19 de maio de 1924 a ideia de um "Noturno de Belo Horizonte", e o poeta pernambucano-carioca já recebe e comenta o poema em 10 de outubro do mesmo ano. Em outras palavras, o poema de Mário é posterior ao quadro, mas não o conhece nem foi influenciado por ele, pelo menos até segunda ordem. O que houve foi, retomando o argumento de Vinícius Dantas, a interpretação pessoal de Mário, de um esforço conjunto dos três artistas paulistas. Isso também vale se pensarmos em Pau-Brasil, fórmula sintética e luminosa da relação entre vanguarda e realidade brasileira. O "Manifesto da Poesia Pau-Brasil" foi publicado no Correio da manhã em 18 de março de 1924, ou seja, poucos meses antes da concepção do "Noturno de Belo Horizonte". Porém, os poemas propriamente ditos de Oswald, como diz Vinícius Dantas, “mesmo que por essa época alguns poemas estivessem esboçados, sua escrita levará todo o ano de 1924, só chegando a seu termo em meados do ano seguinte". ${ }^{306} \mathrm{O}$ que quer dizer que, se houve influência, foi do "Manifesto", mas, nesse caso, o poema de Mário será mais uma resposta, uma formulação pessoal do "Manifesto da Poesia Pau-Brasil" do que uma tomada de posição oswaldiana. Note-se mesmo que, como sentimento mais geral de brasilidade, a expressão oswaldiana "pau-brasil”" foi aceita integralmente por Mário. Ela aparece na "Advertência" de Losango cáqui, datada de 1924: "o meu sentimento possivelmente pau-brasil e romântico", e em carta a Tarsila de $1^{\circ}$ de dezembro de 1924: "Estou

\footnotetext{
305 DANTAS, Vinícius. Entre "A Negra" e a Mata Virgem, cit., p. 102. Há, nas p. 103-108, um desenvolvimento do que pode ser "mata virgem", de acordo com uma série de textos teóricos de Mário sobre arte brasileira.

${ }^{306}$ DANTAS, Vinícius. Oswald de Andrade e a Poesia. Novos estudos. São Paulo, n. 30, p. 196, jul. 1991.
} 
inteiramente pau-brasil e faço uma propaganda danada do paubrasilismo". 307 Como sentimento geral, a adesão é inconteste; como prática poética, a diferença é flagrante. Assim foi sentido pelos grandes interlocutores poéticos de Mário, Manuel Bandeira e Carlos Drummond de Andrade.

O jovem Drummond, grande admirador da inteligência artística de Mário, mas renitente quanto ao nacionalismo em poesia, comenta o "Noturno de Belo Horizonte" em carta de 24 de dezembro de 1924. O poema surte efeito, Drummond o considera "seguramente o maior esforço da poesia nacional". 308 O poeta mineiro ainda escreve: "Ele me fez crer que você tem razão, por isso que suas ideias nacionalistas o conduziram de maneira lógica a um poema tão rico de expressão e intenção, em que o sentimento da terra se confunde com o mais puro e desinteressado lirismo". 309 É interessante notar que, um ano depois, Drummond não recebe bem as pretensões de pioneirismo da "poesia pau-brasil" de Oswald, sobre a qual escreve um artigo para o jornal A Noite. Muito influenciado por Mário, Drummond toma partido: “A grande tolice do meu amigo Oswald de Andrade é imaginar que descobriu o Brasil. Absolutamente não descobriu tal. O que ele fez foi descobrir-se a si mesmo". 310 Estamos ainda diante de um Drummond em processo de formação, modernista apaixonado e mariodeandradiano convicto, mas cujo caminho, entretanto, podemos observar em que linhas foi sendo traçado, e sabemos a que ponto muito alto ele chegou. A opinião de Bandeira era muito parecida com a de Drummond. Em carta de 10 de dezembro de 1924, Bandeira saúda o "Noturno de Belo Horizonte" como "o mais belo poema brasileiro!". ${ }^{311}$ A correspondência com Bandeira permite acompanhar com mais detalhe a recepção e o efeito do poema de Mário, bem como sua relação com a poesia pau-brasil na história do primeiro Modernismo. Em carta de 2 de abril de 1925, Bandeira retorna ao poema: "Você descobriu o grande poema brasileiro. Todas essas

\footnotetext{
307 AMARAL, Aracy (Org.). Correspondência Mário de Andrade \& Tarsila do Amaral, cit., p. 87 e 89. Mário escreveu uma resenha par a o livro Pau-Brasil, de Oswald, em setembro de 1925, que não chegou a publicar. Esse texto foi publicado em BATISTA, Marta Rossetti; LOPEZ, Telê Porto Ancona; LIMA, Yone Soares de. Brasil: $1^{\circ}$ tempo modernista - 1917/29. Documentação. São Paulo: IEB, 1972. Nele, Mário escreve: "Pau-brasil é rótulo condescendente e vago significando para nós iluminadamente a precisão de nacionalidade" (p. 231).

${ }^{308}$ SANTIAGO, Silviano (Org.). Carlos \& Mário. Correspondência de Carlos Drummond de Andrade e Mário de Andrade, cit., p. 80.

${ }^{309}$ SANTIAGO, Silviano (Org.). Carlos \& Mário. Correspondência de Carlos Drummond de Andrade e Mário de Andrade, cit., p. 80.

310 Trecho do artigo de Drummond reproduzido em: SANTIAGO, Silviano (Org.). Carlos \& Mário. Correspondência de Carlos Drummond de Andrade e Mário de Andrade, cit., p. 166.

${ }^{311}$ MORAES, Marco Antônio (Org.). Correspondência Mário de Andrade \& Manuel Bandeira, cit., p. 130.
} 
coisas da terra que você diz tão amendoim-torradamente [...], eu sufocava de dizer. Não sabia como, Você achou como". ${ }^{312}$ E lembre-se de que neste momento poético de Bandeira estão em gestação os poemas de Libertinagem. ${ }^{313}$ Quando recebe o livro PauBrasil, Bandeira tem uma apreciação mais justa do que Drummond, mas mantém sua posição em relação ao "Noturno de Belo Horizonte" e demais poemas brasileiros de Mário, como afirma em carta de 13 de setembro de 1925: "Oswald mandou-me o PauBrasil. [...] O que está dentro é bom, empregando a técnica Kodak de Cendrars. [...] O livro tem coisas deliciosas, do realista Oswald observador irônico. É o que eu chamo o melhor Oswald. Ele sente e critica deliciosamente o Brasil, mas no fundo é pouco Brasil. Pau-Brasil é a tradução de Bois du Brésil. Acho você mais Ibirapitanga". ${ }^{314} \mathrm{Na}$ carta seguinte, de 19 de setembro de 1925, Bandeira retorna ao assunto com mais ênfase, reiterando a influência de Cendrars sobre Oswald, que de fato "não tem importância, pois a técnica é admirável, tem caráter clássico e serviu maravilhosamente às necessidades de expressão do Oswald", mas abordando a questão da brasilidade e da originalidade, assim se manifesta:

Se falei nisso [...] foi porque me aporrinha essa coisa de bancar o inovador em cima da gente. As únicas coisas que não se parecem com os poemas europeus na poesia brasileira de agora são o "Noturno (de Belo Horizonte)", "Tarde, te quero bem" e outras coisas suas, ainda que precisa-se dizer que você não faria nunca se não fossem os europeus. Você é profundamente original, pessoal, brasileiro e barra-fúndico, mas a tudo isso chegou por uma seriíssima, atormentadíssima, dolorosíssima e sublimemíssima cultura europeia modernista. [...]

Por isso, Mário, tenho essa confiança em você. Do ponto de vista brasileiro só você me satisfaz. Eu disse ao Oswald: "Você sente e critica deliciosamente o Brasil mas não é o Brasil; quem é Brasil é o Mário. Você observa, Mário vive isso que você observa. O poeta é ele”. 315

\footnotetext{
312 MORAES, Marco Antônio (Org.). Correspondência Mário de Andrade \& Manuel Bandeira, cit., p. 195. "Amendoim-torradamente" refere-se ao poema de abertura do Clã do jabuti, "O Poeta come Amendoim".

${ }^{313}$ Ver poemas de Bandeira “O Cacto", "Mulheres", "Não Sei Dançar" e "Pensão Familiar”, publicados na revista Estética n. 3, edição em que sai o "Noturno de Belo Horizonte", e essa passagem do mesmo Bandeira em carta de 26 de junho de 1925: "Acho mesmo que convém que nos imitemos, que nos plagiemos, que nos influenciemos para firmar cada vez mais essa característica racial que já é patente e bem definida" (MORAES, Marco Antônio (Org.). Correspondência Mário de Andrade \& Manuel Bandeira, cit., p. 219).

${ }^{314}$ Ibirapitanga é a palavra tupi para "pau-brasil" (MORAES, Marco Antônio (Org.). Correspondência Mário de Andrade \& Manuel Bandeira, cit., p. 238).

${ }^{315}$ MORAES, Marco Antônio (Org.). Correspondência Mário de Andrade \& Manuel Bandeira, cit., p. 241. "Tarde, te quero bem" é como Bandeira chamava "Louvação da Tarde".
} 
Essa pequena história da fortuna crítica entre poetas de "Noturno de Belo Horizonte" e de Pau-Brasil tem como finalidade apontar para um pedaço da história interna da poesia brasileira modernista, e, sem desconhecer o mérito enorme da formulação poética de Oswald, mostrar como dentro dela o "Noturno de Belo Horizonte" aparece como um dos poemas fundamentais, senão o mais fundamental, da década de 1920, do período anterior à “poesia em 1930”, e que foi o poema brasileiro preferido de Manuel Bandeira e Carlos Drummond de Andrade, o que não é pouca coisa.

Resta tentar explicar qual o motivo de fascínio desse poema. Havíamos parado no final da primeira estrofe, momento em que a bela imagem ascendente do matovirgem, da tapeçaria das folhagens e dos "braços cabindas da noite" fechava a imagem maior de uma noite substancialmente pura e acolhedora, a que corresponde um sujeito lírico igualmente puro. Essa será a plataforma da qual o sujeito lírico começa uma observação de largo fôlego, que vai tomando corpo ao longo do poema. Em primeiro lugar, esse eu lírico vê na nova capital uma "luta pavorosa entre florestas e casas..." (verso 16), luta em que o poder telúrico da mata autóctone, uma espécie de forma mítica da mata-virgem, revolta-se contra a arquitetura postiça de uma civilização postiça que os mineiros querem na cidade. Pela extensão do poema, não se pode fazer uma análise minuciosa, nem ao menos uma descrição passo a passo das visões desse eu lírico, sempre composta de vivos achados poéticos, pois isso levaria o leitor ao fastio e não seria possível manter um foco constante. Antes, quero me deter em momentos estruturais fortes, que visam à motivação poética profunda de que as visões do "Noturno de Belo Horizonte" são geradas. Ao longo de seus mais de 400 versos, a diversidade dos caminhos e imagens que o poema percorre é registrada em primeiro lugar pelo ritmo festivo, franco e entrecortado do verso livre; em segundo lugar, por versos-chave que marcam as passagens entre visões de intenção diferente. A primeira marcação ocorre no verso já citado que abre a segunda estrofe:

Que luta pavorosa entre floresta e casas...

A noite, portadora de seres estranhos e poderosos, começa a se abrir à visão do poeta. Construções urbanas e a natureza telúrica se personificam. O foco do poema se define: $\mathrm{o}$ que faz a mediação entre a noite e o eu lírico é a alucinação. Por meio de alucinações, vão surgindo as visões de que o poema se compõe. E, assim que a natureza telúrica 
vence e depõe a civilização postiça, o poema recebe uma nova marcação, um desenvolvimento da alucinação, com os versos:

\author{
E o noturno apagando na sombra o artifício e o defeito \\ Adormece em Belo Horizonte \\ Como um sonho mineiro.
}

Tem festas do Tejuco pelo céu!

(versos 48-52)

À alucinação vêm juntar-se o sonho e a festa, completando o foco alucinação-sonhofesta, que dará o tom do poema até o seu momento final. O poder poético desse foco é praticamente ilimitado, e seu perigo maior é justamente a extrapolação desse poder, em ondas sucessivas de visões desconexas, que perdem a vontade de descobrimento - a intenção hermenêutica - que a justaposição de imagens tem nesse primeiro momento do Modernismo brasileiro. A astúcia hermenêutica de um foco tão poderoso reside na capacidade de ordená-lo a partir de dentro. Não é mais o caso do sonho dirigido apolíneo, presente em "Louvação da Tarde", pois aqui estamos no centro do dionisismo mariodeandradiano. Mas como controlar a embriaguez do ritmo e da festa, a vertigem da alucinação? A forma usual de Mário resolver o dionisismo nos pontos de grande tensão de seus poemas é a dança de palavras, a "constante dionisíaco-coreográfica", notada por Bastide e lastreada pelo próprio Mário. ${ }^{316}$ Em "Noturno de Belo Horizonte", porém, a solução do foco alucinação-sonho-festa não será uma coreografia de significantes, será antes religiosa: o controle do dionisismo por uma coreografia ritual. Os versos-chave, então, não registram somente as transições entre caminhos e visões diversas, eles marcam, nesse percurso, as diferentes fases de uma coreografia ritual.

O sujeito lírico do poema, em estado puro como a noite, é um sujeito capaz de participar do ritual como um recipiente que recebe em si a totalidade das visões e caminhos dessa alucinação-sonho-festa, dessa coreografia ritual. Assim, esvaziado de suas determinações, ele começa a se preencher com as criações da noite. Mas não é um sujeito passivo, dominado por uma força que lhe é externa, é um sujeito ativo, capaz de organizar a linguagem e os procedimentos da coreografia ritual. O modo como o sujeito lírico organiza a alucinação-festa-sonho é pelo procedimento de conjurações. O poeta conjura, entre as forças estranhas e poderosas da noite, aquelas que vão participar do

${ }^{316}$ Ver Capítulo I, nota 124. 
ritual. A primeira força conjurada é a força da história, que segue aos últimos versos citados: as estrelas do céu passam a iluminar a história colonial de Minas, um "bulício de multidões matizadas", em que aparecem nobres, emboabas, carijós, espanhóis, baianos, negros, e para enfatizar a atmosfera alucinatória da visão, comparecem a "ViaLátea" e "os planetas em pessoa". O poder desse foco de alucinação-sonho-festa é reforçado em outra marcação forte do poema, como a reiterar o poder do dionisismo de reconfigurar mundos no espaço mítico da noite:

\author{
Estrelas árvores estrelas \\ E o silêncio fresco da noite deserta. \\ Belo Horizonte desapareceu \\ Transfigurada nas recordações.
}

(versos 68-71)

A conjuração da história colonial é entremeada de descrições, comentários e uma historinha, a do menino que ajuda o cego na estação de trem, pedindo esmola em nome de Nosso Senhor da Boa-Viagem (versos 98-117). Essas histórias intercaladas no poema têm uma função específica, a que voltarei em um momento posterior. Por ora, a história do menino faz a ponte para a segunda conjuração do sujeito lírico: a conjuração do espaço. Com mais um verso-chave - o que inicia a estrofe -, esse lugar propício ao ritual, Minas Gerais, é todo evocado a partir de seus rios:

\footnotetext{
Minas Gerais de assombros e anedotas...

Os mineiros pintam diariamente o céu de azul

Com os pincéis das macaúbas folhudas.

Olha a cascata lá!

Súbita bombarda.

Talvez folha de arbusto,

Ninho de teneném que cai pesado,

Talvez o trem, talvez ninguém...

As águas se assustaram

E o estouro dos rios começou.
}

(versos 118-127)

Com esse cenário, meio irreverente, meio mítico, os rios vão trazer todo o espaço de Minas para dentro do poema: Rio das Mortes, Paraopeba, Paraibuna, Araçuí e São 
Francisco. Com os rios vêm os remeiros cantadores, que desembarcam o poeta na cidade, e história e espaço se unem na conjuração poética do "Noturno de Belo Horizonte". A dupla conjuração completada, o poeta refaz sua própria experiência mineira (versos 184-229), com irreverência e comentários, até chegar a outros versoschave, que farão a transição para outro traço fundamental do poema:

Alegria da noite de Belo Horizonte!
Há uma ausência de males
Na jovialidade infantil do friozinho.
Silêncio brincalhão salta das árvores,
Entra nas casas desce as ruas paradas
E se engrossa agressivo na praça do Mercado.

(versos 230-235)

O vento que vai entrar nesse silêncio trará a lembrança de mais uma história mineira, dos "despenhadeiros assombrados do Rola-Moça", e o poeta conta em um belo poema em redondilha maior, que lembrou a Manuel Bandeira o lied de Goethe ou Uhland, ${ }^{317}$ a história do casal que foi casar do outro lado da serra do Rola-Moça e, na volta, ao cair da noite, em alegria nupcial, o passo em falso do cavalo joga noiva e cavalo despenhadeiro abaixo, no que é prontamente seguida pelo noivo (versos 246-292). Essa história e a do menino que pede esmolas são completadas por uma terceira, em prosa corrida - no meio do poema - sobre o coronel Antônio de Oliveira Leitão, "de orgulhosa nobreza vicentina", que esfaqueou a filha, porque ela flertava, hipoteticamente, com algum plebeu. O coronel foi julgado e decapitado na Bahia, e a mulher reuniu a riqueza da família e mandou construir uma igreja para as almas do marido e da filha (entre os versos 323 e 324). São histórias intercaladas no interior do poema, mas que participam da sua concepção e estruturação. A diversidade das formas chama a atenção à versatilidade do poeta. A primeira história é narrada em versos livres prosaicos, a segunda em forma de lied, e a terceira em prosa corrida, sem quebrar o ritmo e a atitude do espírito que animam o poema. Outra característica dessas histórias é a ausência de caráter edificante. A história do menino, mais próxima da edificação, é mais poética do que edificante, e as duas outras histórias de edificante nada têm, bem como se aproximam do "causo" popular, de experiências extraordinárias que ficam

317 "Balada da 'Serra do Rola-Moça' só encontra parelha em Goethe ou Uhland" (MORAES, Marco Antônio (Org.). Correspondência Mário de Andrade \& Manuel Bandeira, cit., p. 134). 
gravadas na memória do povo. É essa sedimentação que o poema aproveita para seus propósitos. O objetivo dessas histórias inseridas é operar uma terceira e última conjuração: a do povo brasileiro. Esse objetivo é apontado pelo verso 331:

Mas não há nada como histórias pra reunir numa mesma casa...

Anterior a esse verso que expõe o objetivo das histórias, há uma convocação enumerativa de todos os brasileiros, identificados por estado e costumes. Esta última conjuração: "Vem, gente, vem ver o noturno de Belo Horizonte" (verso 307), já faz a transição das conjurações de tempo, espaço e povo para o momento maior do ritual do poema. O poema começa a perder a medida, a organização poética começa a ceder a impulsos discursivos, que saem do poema para a atuação direta na vida. Sujeito lírico e linguagem começam a entrar em transe. Esse transe inicial é ainda atenuado pela história do coronel Leitão e pelo término da terceira conjuração. Mas do último verso citado em diante, o edifício poético desmorona em favor da pregação do amor e da fraternidade na pátria e no universo. Essa etapa não deve enganar o leitor, que pode estar imaginando que o poeta perdeu a mão, que Mário não resistiu a seu verbalismo característico ou que enxertou uma pregação na marra a despeito do poema. Ao contrário, esse trecho final é a culminação da organização do foco de alucinação-sonhofesta, da organização da embriaguez dionisíaca: feitas as conjurações, sujeito lírico e poema entram em transe sacrificial. O sacrifício aparece aqui como característica formal. O sacrifício em favor de uma fraternidade brasileira e universal - mas principalmente brasileira - é um sacrifício simbólico do sujeito lírico que se configura formalmente como sacrifício da linguagem do poema, que deixa de ser poema para se transformar em pregação. Como manifestação material do sacrifício simbólico, é o poema que é sacrificado em sua linguagem em favor da fraternidade brasileira. $\mathrm{O}$ fato de o "poet's poet" de nosso primeiro Modernismo se transformar em pregador não passou desapercebido. Drummond comenta que gostou "ampla, vastamente" do poema, considerando poesia da melhor qualidade. Mas continua: "Só não é poesia (pelo menos assim o creio) o trecho em que você prega o nacionalismo universalista, e que podia figurar num discurso de 15 ou 19 de novembro. Mas o resto, quero dizer, quase todo o 
poema, é esplêndido". ${ }^{318}$ O que Drummond, estritamente poeta, não percebeu, é que justamente esse trecho é o ponto de chegada do apostolado nacionalista de Mário, é a manifestação em poesia do argumento: "acredite que um sacrifício é lindo". 319 E esse sacrifício, sendo o ponto alto do pragmatismo nacionalista de Mário, quer dizer, um objetivo laico, reproduz poeticamente o sacrifício de Cristo, pois o poema morre de amor pelos homens, como se lê nessa passagem:

\author{
Não prego a guerra nem a paz, eu peço amor! \\ Eu peço amor em todos os seus beijos, \\ Beijos de ódio, de cópula ou de fraternidade \\ Não prego a paz universal e eterna, Deus me livre! \\ Eu sempre contei com a imbecilidade vaidosa dos homens \\ E não me agradam os idealistas. \\ E temo que uma paz obrigatória \\ Nos fizesse esquecer o amor \\ Porque mesmo falando de relações de povo e povo \\ O amor não é uma paz \\ E é por amor que Deus nos deu a vida... \\ O amor não é uma paz, bem mais bonito que ela \\ Porque é um completamento!...
}

(versos 346-359)

Nesse momento específico do poema, o que age é o amor cristão, o modelo é Cristo. Mas o significado mítico que engloba o poema todo é dionisíaco, é o ciclo morteressurreição. No fim do poema já há um indício dessa ressurreição, pois a cidade dorme,

\footnotetext{
${ }^{318}$ SANTIAGO, Silviano (Org.). Carlos \& Mário. Correspondência de Carlos Drummond de Andrade e Mário de Andrade, cit., p. 80.

${ }^{319}$ SANTIAGO, Silviano (Org.). Carlos \& Mário. Correspondência de Carlos Drummond de Andrade e Mário de Andrade, cit., p. 51. Mário de Andrade faz uma resenha da revista Estética n. 3, em que o poema foi publicado pela primeira vez, para outra revista, a mineira A Revista, em seu n. 3, de 1926. Aí, Mário comenta o próprio poema "Noturno de Belo Horizonte", e assim se manifesta quanto ao final do poema: "Ao ler o Noturno a gente tem o prazer de um vegetal que sentisse as próprias raízes. O final do poema não tem a mesma força poética do resto. Me parece que se deu ahi, um resfriamento intelectual. As ideas são muito puras e muito frias. A atmosfera é outra. O ar é rarefeito. Respira-se mal. Mas não será preciso dizer que a visão cíclica de Mário exige aquele final que não quebra a unidade da sua poesia" (ANDRADE, Mário de. Estética, $3^{\circ}$ Número. Rio 1925. In: ANDRADE, Carlos Drummond de; MOURA, Emílio; ALMEIDA, Martins de; CANEDO, Gregoriano. A Revista. Belo Horizonte, 1925/1926. Edição fac-similar. São Paulo: Metal Leve, 1978). Não sei determinar o que Mário quer dizer especificamente com "visão cíclica" em sua obra nesses anos 1924-1925; contudo, a própria expressão se coloca automaticamente no campo de significações do mito e, se lembrarmos da contemporaneidade entre a expressão e a defesa do sacrifício nas cartas a Drummond, podemos aproximá-lo do ciclo morteressurreição operado pelo sacrifício.
} 
Mas os poros abertos da cidade

Aspiram com sensualidade com delícia

$\mathrm{O}$ ar da terra elevada.

(versos 400-402)

E os últimos versos trazem o ar e a água como purificação final:

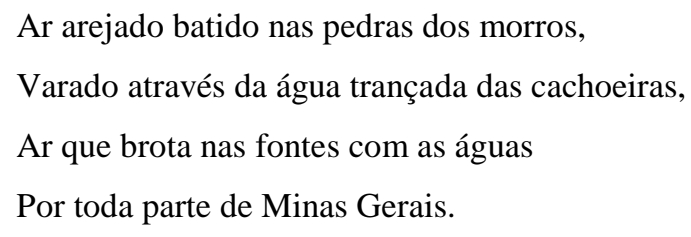

(versos 403-406)

Mas a que se deve esse sacrifício? Como elemento fundamental da esfera do religioso, do sagrado, o sacrifício tem a função de apaziguar a violência, de impedir o surgimento de conflitos. ${ }^{320}$ A violência sacrificial resume em si todas as violências potenciais, eliminando com isso a violência dos homens entre si, e estabelecendo a harmonia de uma comunidade:

Il y a pourtant un dénominateur commun de l'efficacité sacrificielle, d'autant plus visible et prépondérant que l'instituition demeure plus vivante. Ce dénominateur c'est la violence intestine; ce sont les dissensions, les rivalites, les jalousies, les querelles entre proches que le sacrifice prétend d'abord éliminer, c'est l'harmonie de la communauté qu'il restaure. ${ }^{321}$

Cito a passagem porque no trecho de Girard, além de elucidar a questão do sacrifício, a apresentação do "denominador comum" parece uma descrição exata da República Velha. É esse, com efeito, o universo que o poema habita, enfrentando uma questão histórica com as armas do sagrado: eis o alcance, para bem e para mal, do sentimento religioso da vida na poesia de Mário de Andrade. Sendo um poema modernista, ele participa da esfera do sagrado. O poema está pelo próprio sacrifício criando o Brasil fraterno. É o próprio Mário que diz em carta a Drummond de 10 de novembro de 1924: "Nós temos que dar ao Brasil o que ele ainda não tem e por isso até

\footnotetext{
${ }^{320}$ GIRARD, René. La violence et le sacré. Paris: Hachette, 1972. p. 27.

321 "Há, portanto, um denominador comum da eficácia sacrificial, tão mais visível e preponderante quanto mais a instituição ainda está viva. Esse denominador é a violência intestina; são as dissensões, as rivalidades, os ciúmes, as querelas entre próximos que o sacrifício pretende eliminar em primeiro lugar, é a harmonia da comunidade que ele restaura" [tradução livre] (GIRARD, René. La violence et le sacré, cit., p. 19).
} 
agora não viveu, nós temos que dar uma alma ao Brasil e para isso todo sacrifício é grandioso, é sublime. E nos dá felicidade. Eu me sacrifiquei inteiramente". ${ }^{322}$ E o Brasil "não viveu" pela ausência de uma finalidade comum compartilhada, por um tipo de igualdade fundamental que ordenasse e desse sentido aos problemas e conflitos da nação. Nesse quadro ideal, a "alma" do Brasil, a constituição do sujeito social bem individuado e a integridade reflexionante de sujeito lírico e linguagem literária se formariam em homologia. Ou seja, trata-se do ideal de uma modernidade que cumprisse suas promessas no ambiente brasileiro sem violentar as características locais. Por isso, o sacrifício de Mário em sua poesia, possuindo a ambiguidade de toda solução mítica, não é regressivo em relação à realidade brasileira que pretende solucionar. Para comprovar esse argumento, basta um golpe de vista no estado de coisas a que o poema se opunha em seu momento histórico específico, e que se consolidou como traço estrutural da vida brasileira. É conhecida a ausência do elemento fraterno na sociabilidade brasileira, uma sociedade que conhece em minúcias a noção de verticalidade social, sem ter a de horizontalidade. Esse "insolidarismo social”323 é uma herança visível da história política brasileira. Se pensarmos que a solidariedade em contexto europeu é principalmente um fruto de pequenas organizações religiosas mais democráticas ou de uma educação política coletiva, com possibilidade de participação social, veremos que a sociedade brasileira simplesmente desconhece esses mecanismos. A primeira organização ideológica da história brasileira é a Contrarreforma, que cobre quase toda a história colonial inconteste; nossa independência se deu sob égide do Absolutismo monárquico de base escravista; e nossa República é baseada em Comte, o primeiro intelectual definitivamente reacionário na França depois da Revolução. Em outras palavras, o Brasil sempre esteve antenado com a última palavra em autoritarismo da história europeia. Isso do ponto de vista da história política. Do ponto de vista da história social, por sua vez, destaca-se a instituição mais duradoura da história brasileira, a escravidão, que, abolida depois de quase quatro séculos, já havia formado o padrão da sociabilidade brasileira e vive até hoje como herança no modo de pensar e agir do corpo social brasileiro. Com isso, temos, nas palavras de Evaristo Morais Filho, ao historiar o tema,

\footnotetext{
${ }^{322}$ SANTIAGO, Silviano (Org.). Carlos \& Mário. Correspondência de Carlos Drummond de Andrade e Mário de Andrade, cit., p. 51.

${ }^{323}$ MORAIS FILHO, Evaristo. O problema do sindicato único no Brasil: seus fundamentos sociológicos. São Paulo: Alfa-Omega, 1978. p. 315. Na conclusão desse livro há um histórico da percepção da falta de solidariedade na vida brasileira por viajantes, filósofos, historiadores e sociólogos - de que minha exposição se aproveita.
} 
"uma verdadeira constante, que não se cansam os autores de mostrar no caráter do povo brasileiro: a falta de sentimento de cooperação de solidariedade social, de aproximação durável e profunda em associações voluntárias". 324 É num engajamento fraterno e nacionalista, de inflexão religiosa, que Mário de Andrade se opõe a esse estado de coisas, a esse legado da história brasileira, e tenta solucioná-lo pela imersão da forma poética modernista tão profundamente na realidade brasileira a ponto de poder sacrificar a forma poética pela nação. Igualmente do ponto vista da subjetividade lírica, ela se abre para a absorção de todas as características da nação e, principalmente, do ideal fraterno, para que ele seja sacralizado no processo sacrificial.

$* * *$

Todo procedimento simbólico, mítico ou religioso não se esgota no momento em que ele originalmente existiu, mas se renova sempre que o ritual for novamente cumprido. Como Cristo "morre e ressuscita" todo domingo na missa, como Dionísio "morre e retorna" todos os anos na mudança das estações, e como toda obra artística revive quando é novamente contemplada. Assim, o "breviário laico" da poesia de Mário de Andrade que montei neste capítulo não se esgota na contemplação desse dia religioso e sagrado, como se ele fosse um único dia, como se ele fosse um destino histórico que, uma vez cumprido, só pudesse ser retomado pela memória. Isso distingue fundamentalmente esses poemas de significado mítico-religioso do significado histórico de "A Meditação sobre o Tietê", em que a "tristeza que timbra um caminho de morte" é um destino simbólico e biográfico. Ao contrário, "Louvação Matinal”, "Louvação da Tarde" e "Noturno de Belo Horizonte" são poemas simbólicos e míticos. O dia desse "breviário laico" pode ser qualquer dia ou todos os dias, e sempre será o mesmo. Essa participação no mítico-religioso mostra uma das fronteiras que a poesia modernista brasileira pôde habitar e mesmo ultrapassar. Na outra ponta, essa poesia enfrentou e configurou seus materiais de modo inovador e experimental, com alta consciência artística, mesmo quando retomou uma forma consagrada, como em "Louvação da Tarde". Nesse sentido, um poeta modernista conseguiu viver o Brasil em sua poesia sem fazer concessões formais a algum tradicionalismo ideológico. E se ideologicamente a religião e o sacrifício fazem parte do molde familista e católico do paternalismo

\footnotetext{
${ }^{324}$ MORAIS FILHO, Evaristo. O problema do sindicato único no Brasil: seus fundamentos sociológicos, cit., p. 312.
} 
brasileiro, no sentimento religioso da vida da poesia de Mário essa matriz é rompida e reconfigurada. Sacrifício e fraternidade não ocorrem em favor da autoconservação de um molde familiar regressivo, que se impõe sobre uma sociedade desestruturada. Esse molde familiar é transposto para a nação, mas não é transposto sob a égide da autoridade patriarcal - sua posição depõe a figura paterna do topo das relações fraternas e a coloca horizontalmente de acordo com o modelo do materno. ${ }^{325}$ Nesse sentido, Mário de Andrade é menos paternalista do que maternalista. Sendo uma posição discutível em si, em que entram idealismo subjetivo, sublimação da posição social e transferência homossexual, o fato é que ela reestrutura e renova na forma poética a visão do Brasil, tendo função hermenêutica e alcance estético próprios, além da revelar as dificuldades e os limites da solidariedade e da fraternidade na sociedade brasileira. $\mathrm{O}$ que distingue o maternalismo do paternalismo é a ausência de violência em sua natureza, no modo de lidar com o real e com a organização da vida. Enquanto o paternalismo, como derivação abrandada do patriarcalismo, é um modo sutilmente violento de verticalização social, o modelo maternalista de Mário é fundamentalmente uma forma de horizontalidade. No entanto, o maternalismo não está alheio à violência de uma sociedade como a brasileira. Ao contrário, a figura do poeta maternalista faz convergir sobre si a violência social existente ou latente, e busca eliminá-la pelo sacrifício. O resultado é uma poesia em que flui uma concepção não autoritária de Brasil, e dispõe de uma série de sortilégios - com o sacrifício como sortilégio principal - para criar na forma artística um Brasil libertado, consciente de si e autodeterminado. Nesse quadro, é importante enfatizar que a perspectiva do materno não dirige esse Brasil libertado, como algum tipo de ideia-totem, antes o propicia, eliminando-se no sacrifício. É desse modo que um poema como "Noturno de Belo Horizonte" faz sacrifício de si mesmo enquanto poema. A perfeição artística não o seduz, sua função não é ser o poema perfeito, mas propiciar poemas perfeitos. É nessa lógica que o poema desentrava a linguagem brasileira e contribui para os poemas de Manuel Bandeira de Libertinagem; é nessa lógica que o poema convence o jovem poeta Drummond a se ocupar em poesia e fora dela dos problemas brasileiros. Mário dispõe do mito, mas não para investir-se do poder do mito e exercê-lo, o que o tornaria um fascista, mas para

\footnotetext{
${ }^{325}$ Materno tal qual idealizado por Mário, e não a matriarca real, que pode ser, no mais das vezes, apenas o patriarca de sexo trocado e acrescido de sutilezas, como a dona Glória do romance Dom Casmurro, de Machado de Assis. Uma aproximação possível é a da extrapolação amorosa do maternalismo de Mário com a "realidade sem complexos" do matriarcado de Pindorama, presente no Manifesto Antropófago (1928), de Oswald de Andrade.
} 
desentravar uma matéria sufocada, para romper as barreiras da vida postiça e cega na arte e na vida social brasileira. Uma vez cumprida sua função, o mito deixa de existir, ele é um instrumento, um mal necessário para criar uma vida mais livre e mais justa.

Esse foi o ideal principal da poesia e da obra de Mário na década de 1920. Mesmo à época, já coexistia, ao lado desse empenho civilizatório - da ideia do Brasil possível -, as possibilidades regressivas, presentes em seus poemas como manifestações raras, mas pungentes, de profunda melancolia, o outro rio, o futuro rio Tietê de "A Meditação sobre o Tietê". ${ }^{326}$ Nas décadas de 1930 e 1940, a falência da disposição sacrificial faz o dionisismo do poeta ganhar configurações diferentes, mais amargas, mais sofridas. O que ocorre, então, é a impossibilidade do sacrifício positivo, e uma crescente sensação de inutilidade começa a se apossar do poeta. O resultado é o surgimento de disposições destrutivas, que se encaminham para o desejo de um engajamento social mais político.

\footnotetext{
${ }^{326}$ Assim, para citar alguns exemplos, a parte final de "Minha Loucura", ao final de "As Enfibraturas do Ipiranga", de Paulicéia desvairada, a "Toada sem Álcool", de Losango cáqui, e o "Acalanto do Seringueiro", de Clã do jabuti. Remate de Males, fechando a década, já está dividido entre as disposições de 1920 e as novas disposições desiludidas de 1930/1940. Pode-se, ainda, acrescentar a esse quadro o "brilho inútil das estrelas", em que Macunaíma decide habitar, dando a um livro tão alegre um fecho de infinita tristeza.
} 


\title{
CAPÍTULO V - O ENGAJAMENTO DIFÍCIL
}

\author{
Parece que tem momentos nesta vida dura em que \\ a gente se revolta, não é porque queira decididamente \\ se revoltar, mas porque uma força maior move a gente \\ e se fica sem capacidade mais pra não se revoltar.
}

Mário de Andrade. O café

A conhecida "Ode ao Burguês" traz no título, à primeira vista, uma intenção social explícita. Fazendo do "burguês" um alvo para ódio e desqualificação, o poema nega as convenções sociais como um todo, pois o burguês do poema não representa somente uma classe, mas todo um código de comportamento e valores morais. Alinhase ideologicamente, desse modo, com a poesia de vanguarda europeia, que se separou da norma burguesa, abrindo-se ao potencial estético, comportamental e social de formas não burguesas e antiburguesas. Como esquema geral, então, esse ataque ao burguês reproduz a atitude inicial da vanguarda em toda a Europa, em que arte de vanguarda e posição política de esquerda pareciam se identificar naturalmente. ${ }^{327}$ Contudo, essa afinação do poema de Mário de Andrade com a atualidade estética e ideológica da vanguarda ainda traz as marcas de uma forma importada. O poema é uma aclimatação paulista da "poesia do grito" do expressionismo alemão. Nessa poesia, a subjetividade lírica se hipertrofia, procura rechaçar totalmente a sociedade pelo mergulho no Eu, e seu ideal é a negação total, "o grito puro". ${ }^{328}$ No expressionismo alemão, essa negação total propicia inovações poéticas diversas, como a exploração do grotesco urbano, de intenção infamante e blasfema, do pathos social, da desarticulação da linguagem e do verso. A nossa "Ode ao Burguês" incorpora a eloquência destrutiva dos poemas expressionistas, mas está distante das suas inovações imagéticas e metafóricas mais

\footnotetext{
327 "No decurso da Primeira Guerra e antes de Estaline, as opiniões política e esteticamente avançadas conjugavam-se; a quem, na altura, começava a despertar, a arte parecia-lhe a priori ser o que de nenhum modo era historicamente: a priori politicamente de esquerda" (ADORNO, Theodor W. Teoria estética. Lisboa: Edições 70, 2008. p. 381). No Modernismo brasileiro, esse "a priori" durou de 1922 a 1926, quando o Modernismo começa a virar à direita com a "revolução da Anta" e o "Verde-amarelismo" em São Paulo e com a revista Festa, no Rio. A consolidação de um Modernismo à direita tem seu último capítulo na virada católica de Murilo Mendes, com a publicação com Jorge de Lima, em 1935, de Tempo e eternidade. Desde então, a poesia radical-reacionária de Murilo é um dos fatos mais curiosos da poesia brasileira moderna.

${ }^{328}$ ADORNO, Theodor W. Expressionismus und künstlerische Wahrhaftigkeit. Apud ALMEIDA. Jorge de Almeida. Crítica dialética e verdade em Theodor Adorno. Música e verdade nos anos vinte. São Paulo: Ateliê Editorial, 2007. p. 27.
} 
fortes, em que os resultados sociais da cultura burguesa são lançados à face do leitor. Mário explora uma versificação vibrátil, livre e gritada, inserindo diálogos irônicos, e obedecendo ao ritmo psicológico do Eu. Porém, a característica mais específica do poema nesse quadro geral é a sua função descritiva. Ao contrário da adesão do expressionismo alemão ao que não é burguês, incluindo o aristocrático, extirpando a burguesia da poesia, a "Ode ao Burguês" sente a necessidade de passar o "burguêsaristocrata" paulista em revista, como se, para poder negá-lo completamente, fosse antes necessário identificá-lo. Antes de a ciência social brasileira surgir e se deparar com a definição problemática de uma burguesia brasileira, o poema de Mário enfrenta a mesma questão. ${ }^{329}$ A colocação do problema entrelaça uma questão que é ao mesmo tempo estética e social: a quem a vanguarda expressionista se opõe quando chega a São Paulo? Quem é o burguês brasileiro? O que o poema entrevê é a identificação do burguês com o aristocrata. Essa identificação gera dois tipos sociais solidários e complementares: o nouveau riche aristocratizado e o aristocrata decadente. A mesma questão será desenvolvida em maiores detalhes por Oswald de Andrade na peça $O$ rei da vela, um pouco mais de dez anos depois. Em "Ode ao Burguês”, a identificação não é desenvolvida e permanece em germe, porque o objetivo do poema é a expressão da subjetividade lírica hipertrofiada e revoltada, a "poesia do grito" expressionista. O ódio, ecoado no título "ode", é o verdadeiro tema do poema, e o que chama a atenção é o fato de um tema expressionista gerar uma descrição de um tipo social. Ressalte-se igualmente a necessidade de a poesia de vanguarda gerar uma hermenêutica da matéria social pressuposta. $\mathrm{O}$ ataque ao comportamento burguês vai alvejar características que fazem parte da moral burguesa clássica: o cálculo do "burguês-níquel", de "relógios musculares", que "algarismam as manhãs", o decoro dos "temperamentos regulares" de religiosidade hipócrita; e alvos que fazem parte de uma conspicuous consumption de classe decadente: o francês e o piano, a necessidade de joias quando se "morre de fome". Contra esse "burguês-aristocrata", o ódio tira sua energia de um ideal não burguês de vida, principalmente de um contato livre com a natureza, com a "vida dos nossos setembros”, quando “O êxtase fará sempre Sol!”. A função destrutiva desse ódio, que paradoxalmente gera uma hermenêutica social, vai ter seu ponto de chegada em uma vida livre, mas de implicações vagas, em um tipo de primitivismo da vida natural.

\footnotetext{
329 Como apresentação do problema e revisão da categoria "burguês" na história brasileira, ver FERNANDES, Florestan. Questões preliminares de importância interpretativa. A revolução burguesa no Brasil. São Paulo: Globo, 2006.
} 
Da comparação de "Ode ao Burguês" com a poesia expressionista alemã salta aos olhos o desconhecimento que o poema de Mário apresenta dos efeitos destrutivos da ética burguesa sobre a vida social e a constituição da subjetividade. A subjetividade lírica do expressionismo é sobretudo uma subjetividade socialmente acossada, que tem no Eu seu último refúgio antes de ser presa pela engrenagem social. Nesse sentido, o primitivismo de uma vida natural de "Ode ao Burguês" revela promessas de um mundo em que ainda há a coexistência de uma vida burguesa com a pré-burguesa, isto é, a vida meio provinciana da São Paulo de então, com sua burguesia incipiente e com uma vida social pouco administrada. O lugar social dessa subjetividade lírica a que a vida social não dá vértebras mas tampouco acossa, está mais evidente em outro poema de Paulicéia desvairada, "Colloque Sentimental". O título evoca o poema homônimo de Verlaine, que fecha seu livro Fêtes galantes. Do poema de Verlaine, Mário aproveita a estrutura, em que a apresentação de um ambiente é seguida por um diálogo fortuito, cheio de significados evocadores, terminando com um tom melancólico. Pensando nesse poema e em "Ode ao Burguês", pode-se notar o ecletismo das formas poéticas de vanguarda adotadas por Mário em seu livro de 1922. Se a "Ode" aproveita a forma da "poesia do grito" do expressionismo alemão, "Colloque Sentimental" segue a trilha da vertente verlainiana da vanguarda, secundária em relação aos movimentos baseados em manifestos, mas de presença constante na poesia de então. De Verlaine, por meio do simbolismo belga, chegamos ao "penumbrismo", ${ }^{330}$ movimento poético imediatamente anterior à vanguarda, presente na sentimentalidade vaga de Apollinaire e Reverdy, e forte no Brasil, entrando no Modernismo pela poesia de Ribeiro Couto e, principalmente, do primeiro Manuel Bandeira. ${ }^{331}$ Diversas modalidades da vanguarda internacional convergem, então, na relação do eu lírico com a cidade de São Paulo em Paulicéia desvairada. Ao operar com várias estéticas de vanguarda, o livro de Mário de 1922 correria o risco de perder a unidade e transformar-se em uma coleção eclética de estilos. No entanto, Mário transforma um elemento externo, a aclimatação de diversas estéticas, em um elemento interno: a subjetividade multiplicada. O que dá unidade e coerência ao livro, e impede que ele seja somente uma coleção de estilos heterogêneos é a relação de uma subjetividade lírica sistematicamente multiplicada com a matéria local da cidade de São Paulo, cuja modernização em curso lhe conferia lastro de

\footnotetext{
${ }^{330}$ Conhecida também é o termo de sua versão italiana, o "creposcularismo".

331 GOLDSTEIN, Norma. Do Penumbrismo ao Modernismo: o primeiro Bandeira e outros poetas significativos. São Paulo: Ática, 1983.
} 
universalidade. Assim, a multiplicidade do sujeito lírico é um modo atualizado esteticamente de conhecer-se a si mesmo e, simultaneamente, um modo de acertar seus ponteiros com a nova metrópole brasileira, que também se multiplicava. Essa relação de conhecimento que possui a subjetividade lírica de Mário em relação a si mesma e à cidade em Paulicéia desvairada acrescenta à sua função estética uma função hermenêutica complementar. Entendida a lógica das diversas estéticas nesse livro de Mário, podemos voltar ao penumbrismo. O seu aproveitamento é dirigido pela ironia em dois níveis: pelo aproveitamento urbano e público de uma poesia ultrassubjetivista, e pela introdução do tema social no poema. Suas duas estrofes iniciais apresentam o sujeito em situação urbana, com os sentimentos subjetivos mesclados à descrição modernista do bairro de Higienópolis. Nessa ambientação da subjetividade, o teor dos versos modernistas é principalmente moral, como se lê na primeira estrofe:

\footnotetext{
Tenho os pés chagados nos espinhos das calçadas...

Higienópolis!... As Babilônias dos meus desejos baixos...

Casas nobres de estilo... Enriqueceres em tragédias...
}

Mas a noite é toda um véu-de-noiva ao luar!

(versos 1-4)

A sentimentalidade penumbrista é casada ao procedimento de montagem futuristacubista, amplificando o potencial sensível do ambiente urbano, criado pelo conhecido verso harmônico de "Prefácio Interessantíssimo": pela justaposição de sintagmas que constroem um sentido complexo pela desagregação da sintaxe e da morfologia normativas. No caso, a mistura de procedimentos de vanguarda e sentimentalidade penumbrista rompe, por um lado, o subjetivismo excessivo do penumbrismo, e, por outro, subjetiviza as técnicas de vanguarda. Além disso, o passo a mais na elaboração poética de Mário é que esse procedimento mesclado apresenta uma má consciência moral. Essa má consciência moral se torna uma matéria local em si mesma, do ponto de vista da constituição social da subjetividade, e unifica os procedimentos e linhagens diversas do poema em um problema central. O desenvolvimento poético do dilema da má consciência social estrutura e dá sentido à diversidade de linguagens utilizada. Assim, uma vez entendido o sentido da estruturação heterogênea, podemos desenvolver o lugar social dessa subjetividade lírica. Esse lugar social se explicita no diálogo: 
- Cavalheiro... - Sou conde! - Perdão.

Sabe que existe um Brás, um Bom Retiro?

- Apre! Respiro... Pensei que era pedido.

Só conheço Paris!

- Venha comigo então.

Esqueça um pouco os braços da vizinha...

- Percebeu, hein! Dou-lhe gorgeta e cale-se.

O sultão tem dez mil... Mas eu sou conde!

- Vê? Estas paragens trevas de silêncio...

Nada de asas, nada de alegria... A Lua...

A rua toda nua... As casas sem luzes...

E a mirra dos martírios inconscientes...

- Deixe-me pôr o lenço no nariz.

Tenho todos os perfumes de Paris!

- Mas olhe, em baixo das portas, a escorrer...

- Para os esgotos! Para os esgotos!

- ... a escorrer,

Um fio de lágrimas sem nome!

(versos 15-31)

Para uma leitura do lugar social do sujeito lírico nesse diálogo, será necessário aceitar provisoriamente o interesse do pieguismo que escorre por essas linhas e cujo resultado propriamente poético é fraco. A forma se enfraquece ao dispor de lugarescomuns exteriores e convencionais, que caricaturizam as posições sociais: rico frívolo e pobre sofredor. O seu interesse maior é a documentação do modo como o sujeito lírico mariodeandradiano se relaciona com os sujeitos sociais da matéria local paulista. Em “Colloque Sentimental", o contato do eu lírico já não é com um "burguês" odiado e repelido, mas com um tipo aristocrático de Higienópolis com quem o eu lírico aceita dialogar cordialmente, e seu meio de comunicação não é o ataque, mas o diálogo. O 
setor social em que esse eu lírico dialoga é o da aristocracia, o da burguesia-aristocrática paulista, o que deixa claro a esfera de pertencimento do sujeito e da linguagem poética. No entanto, esse pertencimento está pejado de reprovações morais, seja do ponto de vista do eu nas referências bíblicas dos dois primeiros versos, seja do ponto de vista social no diálogo. O poeta esboça a crítica católica do capitalismo, que tem implicações tão ou mais obscurantistas que a própria lógica do capitalismo, mas o seu funcionamento no ambiente paulista ganha matizes. Sendo o catolicismo oficial apenas um setor das esferas dirigentes no Brasil, ${ }^{332}$ a retomada por Mário de Andrade do catolicismo mais complexo da análise da consciência e da igualdade de todos perante Deus adquire inesperada função crítica do ponto de vista laico. Com isso, o sujeito lírico vai estabelecer uma relação problemática de adesão a duas classes sociais. O poeta se distancia de sua esfera de pertencimento, cobrindo o aristocrata de ridículo, mas é ele o seu interlocutor, e a incursão de ambos pelos então bairros pobres proletarizados do Brás e do Bom Retiro parece ter a intenção de levar a cabo uma reforma moral do aristocrata, entroncando na modalidade bem brasileira do paternalismo esclarecido. $\mathrm{O}$ poeta, dirigido pela moralidade cristã, deseja unir as duas pontas da sociedade, a aristocrática e a miserável, que, ativando os valores da fé, do amor e da caridade, construiriam um mundo melhor para os corpos na terra e para os espíritos no céu. Há sobejas razões para que essa interpretação de um Mário católico, reformista e paternalista prevaleça, e o poema parece justificá-la. Porém, quero argumentar que essa interpretação apresenta uma fissura e abre a possibilidade de outra, que não vai substituí-la, mas conviver com ela, estabelecendo a difícil e problemática dualidade das convicções sociais de Mário. O que abre essa outra interpretação é a enorme tolice que caracteriza o aristocrata em questão. Despaisado, conspícuo e priápico, seria necessário um milagre para reformar moralmente o nosso conde, milagre que o poeta não tenta realizar. Antes, o que acontece é uma comoção do eu lírico diante da miséria. Nesse caso, conviveria com o paternalismo esclarecido uma desidentificação de classe. Nesse outro polo da dualidade de posições sociais, a má consciência, desidentificada da classe dirigente a que deveria fazer a justificação e apologia, se volta à outra classe, social e moralmente rebaixada, criando um germe de populismo modernista. Essa condição do intelectual de desidentificar-se da classe que deveria representar e justificar, e gerar um populismo pela solidariedade com os desqualificados foi o que gerou, no caso russo,

\footnotetext{
${ }^{332}$ Sobre o funcionamento da Igreja Católica no Brasil durante a República Velha, ver MICELI, Sérgio. A elite eclesiástica brasileira: 1890-1930. São Paulo: Companhia das Letras, 2009.
} 
uma intelligentsia transformadora. ${ }^{333} \mathrm{O}$ que ocorre nesse diálogo de "Colloque Sentimental" é um germe somente, e, do ponto de vista coletivo, constitui uma exceção no primeiro Modernismo. O que se deve notar, entretanto, é a inquietação do sujeito lírico de Paulicéia desvairada quanto a seu lugar social, e o seu empenho hermenêutico em mapear a matéria local em que a subjetividade lírica se desdobra. Sendo ao mesmo tempo paternalismo esclarecido e indício de intelligentsia a que o Modernismo de 1920 não podia fazer eco, a posição solitária nesse sentido de Mário acirra sua inquietação social na medida em que vai definindo o papel nacionalista de sua poesia.

\section{Estranhamento Cordial}

Cedo Mário de Andrade vai mudar seu interlocutor, ou diversificá-lo, pela sua imersão progressiva na esfera da cultura popular, principalmente na música e na linguagem. Para esse novo desenvolvimento de linguagens e interlocutores poéticos, foram fundamentais sua imersão em estudos de cultura popular e a descoberta da diversidade geográfico-cultural do Brasil. Desse esforço se desdobram as "viagens de descobrimento", que vão de 1923 ao fim de 1927: Rio de Janeiro, Minas Gerais, Amazônia, Nordeste. O resultado é uma mudança de interlocução, que tira os olhos da metrópole paulista e percorre o carnaval carioca, Minas colonial, a nova Belo Horizonte, o rio Amazonas e a paisagem geográfico-cultural do Nordeste. Fruto desse esforço é o livro Clã do jabuti. Sua produção não decorre diretamente de todas as viagens - Amazônia e Nordeste foram visitados depois do livro escrito -, mas viagens e poemas do Clã compõem o mesmo esforço de criar uma totalização do Brasil por meio da recuperação e elaboração de sua cultura popular filtrada por um espírito artístico e moderno (mas não necessariamente erudito). Esse populismo de linguagem, temas e formas não nasce de uma projeção de anseios de intelectual sobre um povo idealizado, mas se desenvolve em contato com os materiais artísticos da cultura popular: toada, moda, acalanto, samba, lenda, coco. Além dessa recuperação criteriosa de formas

\footnotetext{
333 “... o divórcio em países de capitalismo tardio e periférico entre classes dominantes e subalternas, dá, muitas vezes, origem a outro divórcio no interior do primeiro grupo. Esse divórcio é entre as classes dominantes e aqueles que deveriam ser seus ideólogos, os 'homens cultos', que não se sentem inteiramente à vontade em tal papel. Cria-se, assim, um grupo, ou melhor, a impressão da existência de um grupo, na maior parte dos casos proveniente das classes dominantes, mas que se sente deslocado delas, algo como a intelligentsia russa" (RICUPERO, Bernardo. Caio Prado Jr. e a nacionalização do marxismo no Brasil. São Paulo: Departamento de Ciência Política da Universidade de São Paulo/Fapesp/Editora 34, 2000. p. 52).
} 
populares, há ainda o poema longo nacionalista e o objet trouvé da vida nacional e popular. ${ }^{334}$ Como forma, o poema longo nacionalista é um modo de abarcar a heterogeneidade e a diversidade da vida brasileira por uma sensibilidade ativa e modernizante. Seu objetivo é uma síntese nacional e subjetiva, a totalização de um Brasil original e moderno, capaz de integrar com feição própria o concerto universal das nações. Assim são "O Poeta come Amendoim”, "Carnaval Carioca" e "Noturno de Belo Horizonte". ${ }^{335} \mathrm{O}$ objet trouvé é aqui a formalização poética de instantâneos observados, como "Viuvita", ou um instantâneo da sensibilidade, um objet trouvé da própria vida subjetiva em contato com o nacional e o popular. Este é o caso do "Descobrimento", o primeiro dos "Dois Poemas Acreanos":

\begin{abstract}
Abancado à escrivaninha em São Paulo
$\mathrm{Na}$ minha casa da rua Lopes Chaves

De sopetão senti um friúme por dentro.

Fiquei trêmulo, muito comovido

Com o livro palerma olhando pra mim.
\end{abstract}

Não vê que me lembrei lá no norte, meu Deus!, muito longe de mim,

$\mathrm{Na}$ escuridão ativa da noite que caiu,

Um homem pálido, magro de cabelo escorrendo nos olhos

Depois de fazer uma pele com a borracha do dia,

Faz pouco se deitou, está dormindo.

Esse homem é brasileiro que nem eu...

Um instantâneo da sensibilidade entreabre um prisma nacional: a distância, a diferença, a incomunicalidade dos homens que se igualam sob o adjetivo "brasileiro". A composição poética desse instantâneo é um tipo de poesia pau-brasil subjetivada, de

\footnotetext{
${ }^{334}$ Populismo nacional e popular do folclorismo da poesia modernista da década de 1920, e não populismo nacional-popular como se deu no Brasil na cultura geral da década de 1950 e início dos anos 1960.

335 O desenvolvimento dessa forma não é pleno e pacífico. "Carnaval Carioca" precisa ultrapassar o poema e ser um convite à sensorialidade biográfica e amorosa, como expus no Capítulo III desta tese; "Noturno de Belo Horizonte" lança mão do rito e do sacrifício para alcançar uma totalização, como expus no Capítulo IV. Note-se, porém, a estrutura lógica, de intenção artística e criteriosa do poema longo nacionalista de Mário, que se distingue dos poemas longos mais frouxos, que fazem apenas a mimese da vida popular ou da história colonial em poesia. Forma frouxa e tediosa que proliferou sob os mais diversos matizes artísticos e ideológicos na poesia nacionalista entre 1925 e 1929. Principalmente, distingue-se o poema longo nacionalista de Mário das grandes apologias da história colonial presentes em Guilherme de Almeida, Raça (1925); Ronald de Carvalho, Toda a América (1926); Cassiano Ricardo, Martim Cererê (1928); e Jorge de Lima, Poemas (1927) e Novos poemas (1929).
} 
versos livres que mesclam o prosaico e o poético. Há também uma fina utilização da linguagem popular como expressão dos movimentos da espontaneidade psicológica em expressões, adjetivação e sintaxe. Assim a função poética da expressão "de sopetão", fazendo vibrar os versos prosaicos anteriores e abrindo a poeticidade do terceiro verso, com seu "sopetão" rítmico; o "livro palerma", cujo adjetivo devolve ao prosaico a expressão que começava a se sentimentalizar; as elipses sintáticas de fala conversada no primeiro verso da segunda estrofe; e o comparativo popular "que nem" na chave de ouro modernista que fecha o poema, ironizando a chave de ouro, de certo modo inovando-a, e fechando o susto, que é o assunto do poema. Um susto da igualdade entre homens tão diferentes.

O segundo dos poemas acreanos, o "Acalanto do Seringueiro", aproveita um fato circunstancial do primeiro poema, "a noite ativa que caiu", para tentar elaborar um acalanto para o seringueiro. Antes de prosseguir à análise desse poema, é útil ter em mente que o seringueiro não era um assunto poético novo na década de 1920. As décadas anteriores tiveram uma corrente de nacionalismo ufanista em forma parnasiana, cujo ilustre antecessor era "O Caçador de Esmeraldas", de Olavo Bilac. Os temas nacionais proliferaram, gerando verdadeiros mapas poético-cívicos de geografia e história do Brasil. Exemplos selecionados um pouco ao acaso iluminam o panorama: Batista Cepelos em Os bandeirantes (1906, obra refundida e modificada para a $3^{\text {a }}$ edição de 1911), prefaciado por Olavo Bilac, segue os bandeirantes e todos os temas possíveis de orgulho nacional; Humberto de Campos, em sua obra poética que se inicia em 1904 e entra pela década de 1930, desenvolve um extenso temário nacional, da geografia do Norte e da história pátria; a musa cívica aparece em Vicente de Carvalho, em poemas como "Fugindo ao Cativeiro" e "A Partida da Monção", ambos de Poemas e canções (1912); mesmo o militante anarquista José Oiticica tem um grupo de poemas sobre o trabalho no Brasil em forma de sonetos parnasianos em Sonetos, $2^{\mathrm{a}}$ Série (1918); ${ }^{336}$ o nacionalismo ufanista mais cafeeiro desponta em Juca mulato (1917), de Menotti del Picchia; e no mesmo ano de 1922, um Ricardo Gonçalves lança Ipês, de temário regionalista caipira, publicado e prefaciado por Monteiro Lobato. ${ }^{337}$ O problema

\footnotetext{
336 São eles "Os Portos", “Os Seringais", “Os Canaviais” e “As Minas” (OITICICA, José. Sonetos. 2a Série (1911-1918). Maceió: Linotypia da Casa Ramalho, 1919. p. 164-167).

337 A melhor antologia de poesia "pré-modernista", em que se encontram esses poetas citados, entre muitas outras vertentes poéticas do período, é a de Fernando Góes (Panorama da poesia brasileira. $O$ Pré-modernismo. Rio de Janeiro: Editora Civilização Brasileira, 1960. v. V). Mais um exemplo de nacionalismo cívico e ufanista de então é o fato de o Tratado de versificação de Bilac e Guimarães Passos
} 
de toda essa produção, em maior ou menor grau presente em todos os poemas, é que ela enfatiza os defeitos do Parnasianismo no Brasil: o tema poético como pretexto para o preciosismo verbal e uma sentimentalidade piegas e domingueira, gerando uma espécie de poemário cívico para a educação das crianças e deleite da família brasileira. Foi, no entanto, essa modalidade arquiprovinciana da vida mental brasileira que garantiu a vitória rápida do Modernismo nacionalista - uma vez vencida a resistência às formas da vanguarda - e que esgotou seu potencial crítico em pouco mais de cinco anos e favoreceu as vertentes ideológicas e conservadoras do Modernismo nacionalista. ${ }^{338}$ Do ponto de vista, então, da relação entre forma literária e história das ideias, seria de grande relevância um estudo das continuidades entre o ufanismo parnasiano e o nacionalismo modernista, para se avaliar também o teor e o alcance dos momentos em que há ruptura ideológica, e quais são suas consequências formais. O que importa aqui para este trabalho é, sem perder de vista esse quadro mais amplo, especificamente o prisma de soluções formais e ideológicas em torno da figura do seringueiro. Anteriores ao poema de Mário há, ao menos, dois poemas sobre o seringueiro que mereceram participar da antologia citada de Fernando Góes: "O Seringueiro", de Humberto de Campos, e "Os Seringais", de José Oiticica. As soluções parnasiano-acadêmica e parnasiano-anarquista vão auxiliar na apreciação da solução modernista-hermenêutica de Mário de Andrade.

No poema de Humberto de Campos, o seringueiro é um continuador da empresa “civilizatória" colonial que remonta a Anchieta:

(1910) só trazer exemplos poéticos da história da poesia brasileira, ver BILAC, Olavo; PASSOS, Guimarães. Tratado de versificação. Rio de Janeiro: Livraria Francisco Alves, 1944.

${ }^{338}$ Penso no período entre o "Manifesto da Poesia Pau-Brasil" e a Pau-Brasil (1924-1925), de Oswald, e no ensaio "A poesia em 1930", de Mário, período abertamente nacionalista, em um espírito programático de temas e posição da sensibilidade. O Modernismo nacionalista conservador começou cedo, com o Verde-amarelismo, a Anta, seguidos pelo Integralismo e pelo renouveau catholique nacional, culminando no nacionalismo autoritário do Estado Novo. A vitória rápida do Modernismo nacionalista surpreendeu Mário: "Confesso que quando me pus trabalhando pró-brasilidade complexa e integral (coisa que não se resume como tantos imaginaram no trabalho da linguagem) confesso que nunca supus a vitória tão fácil e o ritmo tão pegável. Pegou. Eu estava disposto a dedicar minha vida pro trabalho. Bastaram uns poucos de anos" (Carta a Drummond de 28 de fevereiro de 1928 em SANTIAGO, Silviano (Org.). Carlos \& Mário. Correspondência de Carlos Drummond de Andrade e Mário de Andrade. Rio de Janeiro: Bem-TeVi, 2002. p. 321). 


\section{O Seringueiro}

O homem perdido na solidão abso-

luta, vai procurar o bárbaro, levando a escolta única das dezoito balas da sua

Winchester carregada. - EUCLIDES DA

CUNHA. À margem da História, pág. 83.

Profano Anchieta que um mau sonho afaga,

Para que o rito não se extinga ou quebre,

Entras a selva, em que teu ser se apaga,

E ergues, como teu templo, o teu casebre.

No inverno, quando o seringal se alaga,

Não se vê na missão quem não celebre,

Com hóstias de quinino, e boca em praga,

A missa arquilitúrgica da Febre.

És missionário sem burel e estola;

Tens na mão a semente das cidades

Que semeias sem Cristo e sem Loyola.

Basta, para um sermão, que a flecha sifle...

- Como são convincentes as verdades

Dos dezoito Evangelhos do teu rifle!...

A conclusão racional, que a forma tradicional do soneto tradicional pede, faz o poeta trair-se e desideologizar-se involuntariamente: evangelho e rifle fazem a mesma metáfora sempre que alguma população indígena obstrui nosso caminho mercantil. É de um cômico interessante esse vislumbre da verdade histórica pela necessidade de uma chave de ouro. Contudo, à parte esse final, a intenção do poema é laudatória, dentro da esfera parnasiana de preciosismo formal e adesão ao discurso oficial. O seringueiro é transformado em uma mistura de bandeirante e jesuíta, permitindo que o poeta espalhe o vocabulário histórico-religioso pelo poema, e ao mesmo tempo obedeça à epígrafe de Euclides da Cunha, que parece presidir à concepção do poema. A necessidade da elaboração pomposa da forma parnasiana se casa com um sentido heroico da história 
brasileira, construindo a lógica formal e ideológica do civismo oficialista de nossa República Velha.

A mesma elaboração pomposa pretende adquirir outro significado no poema de José Oiticica:

\section{Os Seringais}

Longe, na vastidão do Amazonas enorme,

Crescem, fartas de seiva, as héveas colossais!

Terra grande e ignorada, onde a guariba dorme

E uma raça de heróis percorre os seringais.

Florestas, rios! Sempre o verdor uniforme

De matas e o fulgor de águas plenas e iguais...

E ninguém que proteja essa terra e a transforme,

Fazendo-a, terra sã, produzir muito mais.

Escravo da savana, infernado da Hileia,

Sem destino, sem pão, sem leis, sem lar, sem trato,

Trabalha o seringueiro, estranho ao seu país.

É o drama silencioso, a remota epopeia

Do povo do sertão que, no Brasil ingrato,

Vive desamparado, oprimido e infeliz.

Uma das infelicidades do poema é a escolha do verso alexandrino, o que o torna ainda mais solene do que os decassílabos de Humberto de Campos. Mas é em suas infelicidades estéticas que reside o interesse do soneto. Esse anarquista de vida inteira, militante ativo, tenta inserir um conteúdo social em sua poesia. O resultado, contudo, é um mau conteúdo social e uma forma parnasiana pífia. A solução canhestra pode ser observada na rima "Hileia/epopeia", que fariam o eco do heroísmo do seringueiro. Mas os dois termos, o científico "hileia" e o clássico "epopeia", são antípodas do significado dos tercetos, em que a "raça de heróis" dos quartetos se transforma em trabalhador entregue ao próprio destino, “desamparado, oprimido e infeliz". Em outras palavras, é um poema feito de desencontros formais e ideológicos, de grandes incoerências, mas cuja leitura interessa. Tentando obedecer à coerência formal parnasiana e à coerência social da militância, o poema acaba por adquirir uma incoerência formal e uma 
incoerência ideológica. O poema faz o elogio de heróis pobres-diabos, e de uma natureza magnífica e à deriva. E, no entanto, o interesse de manter o padrão de uma forma poética ao mesmo tempo que se atinava para uma realidade nova que se configurava no Brasil, revela pertinência inesperada. O que faltava a Oiticica era uma atitude acurada quanto à forma poética, que devia ser questionada pela nova realidade; $\mathrm{e}$ uma atitude acurada em relação à nova realidade, que escapava do raio de significados de uma forma poética determinada.

Com essa conclusão, estamos encaminhados para uma questão central que reaparece em "Acalanto do Seringueiro", de Mário de Andrade. Muito provavelmente, nosso poeta não leu os dois poemas acima reproduzidos e, se leu, nada os evoca em seus "Dois Poemas Acreanos". O que é significativo, como disse acima, é verificar a continuidade ou a ruptura entre o ufanismo parnasiano e o nacionalismo modernista por meio de um caso específico. Em relação ao tema do seringueiro há uma grande ruptura. Mário vai demonstrar poeticamente toda a acuidade que falta a José Oiticica, bem como tomar o partido oposto do colonialismo de Humberto de Campos. Em primeiro lugar, Mário não vai enquadrar o seringueiro em um grande sopro histórico de dimensões épicas e amazônicas. Ele vai tentar conhecer o seringueiro como uma pessoa comum, brasileiro que nem ele, mas do outro lado, em termos geográficos e sociais, desse Brasil comum. Com isso, as liberdades no uso da linguagem popular ganham um sentido social, um sentido de comunicação entre classes. Mas respeitando a acuidade artística dessa comunicação, Mário não vai dispor o verso livre cheio de potencialidade de conversa coloquial, mas a forma poética popular por excelência, a canção em redondilha maior. ${ }^{339}$ Mário de Andrade respeita a cristalização da cultura popular e vai afinar seu poema em uma linguagem que possa abarcar as liberdades modernistas de linguagem e o ritmo popular da canção. O uso do verso livre seria aqui deslocado, pois socialmente ele era propriedade de um círculo restrito de intelectuais com acesso à

\footnotetext{
${ }^{339}$ Há sobre a relação entre o verso livre e o verso metrificado essa interessante reflexão de Mário: "O verso-livre adquiriu hoje definitivamente direitos de existência. É a terceira métrica; levou meio-século para implantar-se. Mas não creio se fique nele. Sendo o mais primitivo dos meios de versejar, é ao mesmo tempo o mais erudito. Requer a rica educação das elites. Não se popularizará. O povo, a grande maioria dos ledores (sempre povo) pede aquela rítmica fácil, em que a volta das mesmas medidas e a regular coincidência dos acentos ajudam a compreensão, despertam a memória e embalam sensualmente" (ANDRADE, Mário de. Blaise Cendrars [1924]. In: EULALIO. Alexandre. A aventura brasileira de Blaise Cendrars: ensaio, cronologia, filme, depoimento, antologia, desenhos, conferências, correspondência, traduções. 2. ed. rev. e ampl. por Carlos Augusto Calil. São Paulo: Edusp/Fapesp, 2001. p. 392).
} 
vanguarda internacional, e seu uso repetiria, em forma modernista, o equívoco de Humberto de Campos e José Oiticica em forma parnasiana.

Assim, nas últimas páginas de Clã do jabuti, o poeta vai desenvolver uma forma para abordar o seu interlocutor mais radicalmente oposto. Se em Paulicéia desvairada o contato social se dá basicamente com o tipo social com quem o poeta convive, de quem o poeta sabe virtudes e vícios, e, principalmente, sabe que linguagem usar para a comunicação, em "Acalanto do Seringueiro", o interlocutor é o tipo social mais distante possível. O seringueiro habita a região mais nova e longínqua do país, no trabalho menos amparado pela cidadania moderna, e cuja atividade mental lhe era completamente desconhecida. Por isso, a disposição do eu lírico passa de crítica ou esclarecida a uma atividade de descobrimento.

Agora, em relação a "Colloque Sentimental”, é o próprio eu lírico que precisa reconhecer a outra ponta, neste caso geográfica, do todo brasileiro. O reconhecimento é mais complexo, pois o poeta vê na desigualdade a igualdade, no caso, o pertencimento nacional. Junto ao conhecimento, contudo, há um estranhamento. Em Mário, a possibilidade de vencer o estranhamento é o afeto, como se lê no início do poema:

\footnotetext{
Seringueiro brasileiro,

$\mathrm{Na}$ escureza da floresta

Seringueiro, dorme.

Ponteando o amor eu forcejo

Pra cantar uma cantiga

Que faça você dormir.
}

A mediação desse contato é o sentimento, o "ponteando o amor". Esses versos iniciais ainda colocam o poema entre a disposição hermenêutica e a atitude paternalista. A possibilidade de vencer o estranhamento pelo amor, uma solução sintética e rápida de um estranhamento cordial, levaria o poema para a órbita de um paternalismo renovado, modernista. Amando o seringueiro abandonado, o poeta reativaria a compaixão cristã e seu lugar social formaria com a bondade misericordiosa de espíritos que são elevados espiritual e socialmente. Caso seguisse esse caminho, Mário usaria a acuidade formal em função de uma justificação ideológica, fazendo um movimento muito habilidoso em direção ao Modernismo conservador. No entanto, o afeto e o sentimento no poema têm seus limites, e num momento muito alto da expressão poética mariodeandradiana, o problema da comunicação, a sua impossibilidade, é descoberto e trazido para a 
linguagem, tornando propriamente poética uma experiência profundamente enraizada no solo histórico-social brasileiro:

\footnotetext{
Que dificuldade enorme!

Quero cantar e não posso,

Quero sentir e não sinto

A palavra brasileira

Que faça você dormir...
}

Não achar a "palavra brasileira" é o maior feito e o maior alcance da linguagem do poema. A desconexão entre os homens brasileiros, sua incapacidade de fraternidade ou de mobilização por um ideal comum passa a ser o assunto do poema. O poema obedeceu inicialmente a uma intuição, fruto da sensibilidade de poeta e dos estudos folcloristas, e sentiu a distância entre seu eu lírico e o seringueiro. Porém, ele agora faz aceder intelectualmente à consciência o que é provavelmente o tema central do pensamento sobre o Brasil, das "interpretações do Brasil": a dificuldade de sua integração social. Em termos de uma década e meia depois da publicação desse poema, o que aqui é "a pesada profundidade sob a canção sem peso", ${ }^{340}$ vai se tornar o núcleo da reflexão das grandes "interpretações do Brasil". Como fazer com que uma justaposição desagregada se torne uma integração nacional? Com respostas diferentes, Gilberto Freyre em Casa-grande \& senzala (1933), Sérgio Buarque de Holanda em Raízes do Brasil (1936) e Caio Prado Jr. em Formação do Brasil contemporâneo (1942) se perguntam a mesma coisa: qual é a palavra brasileira que pode unir os homens e pacificar a sensação generalizada de insignificância. De uma perspectiva moral, é como se perguntassem: será um dia possível, no Brasil, dormir o sono dos justos? Desde então, essa questão não deixou de ter validade. Mário, no acalanto que estamos acompanhando, trouxe à consciência a intuição de uma vida coletiva desagregada no centro mesmo de seu grande esforço de unificação folclórica. A sequência do poema é praticamente um estudo poético da distância entre os homens unidos formalmente pela nacionalidade comum. A primeira resposta é uma intenção hermenêutica:

\footnotetext{
340 “A sombra não tem nenhum poder sobre a imagem da vida que retorna a si mesma, mas somente ela confere ao sonho, como última lembrança de sua deformação, a pesada profundidade sob a canção sem peso" (ADORNO, Theodor W. Palestra sobre lírica e sociedade. Notas de literatura I. São Paulo: Duas Cidades/Editora 34, 2003. p. 71).
} 
Como será a escureza

Desse mato-virgem do Acre?

Como serão os aromas

A macieza ou a aspereza

Desse chão que também é meu?

Nosso poeta não sabe e não sente a "palavra brasileira" porque ele não conhece o Brasil. Não se pode unificar no sentimento ou no conceito algo que não se sabe o que é. Se essa consideração, que deveria ser óbvia, já tem efeito inquietante em contexto brasileiro, nosso poeta quer ir além, pois sua experiência intelectual tem de ser complementada pela experiência sensorial. Só o estudo não lhe basta:

\footnotetext{
Que miséria! Eu não escuto

A nota do uirapuru!...

Tenho de ver por tabela,

Sentir pelo que me contam,

Você, seringueiro do Acre,

Brasileiro que nem eu.
}

Nessa "hermenêutica sensorial" já entra uma erótica do conhecimento, estrutural em Mário de Andrade, que em outro contexto vimos na análise de "Carnaval Carioca", no Capítulo III. A defesa da sensorialidade como modo de conhecimento na poesia de Mário possui um aspecto dúbio, de vida imediata sem mediação do poético, que desfaz a universalidade do conhecimento no prazer que se consuma no ato. Mas igualmente, esse prazer nas coisas esgarça a forma poética, dota-lhe de uma sobrecarga de elementos eróticos, que dão relevo aos objetos poéticos. O que Mário chama de sua "pansexualidade", 341 que provavelmente é um modo de transferência da homossexualidade, se infunde na hermenêutica de sua poesia e produz um efeito duplo: particulariza sensorialmente o objeto, ameaçando o conhecimento por uma erótica autorreferente; e potencializa o relevo dos objetos, aumentando seu poder de torná-los poeticamente inteligíveis ao leitor. A poesia de Mário normalmente deixa essa ambiguidade no limite - conhecimento erótico e erótica do conhecimento -, de certa forma particularizando demais a pesquisa poética, mas igualmente imergindo como

\footnotetext{
${ }^{341}$ Em carta a Oneyda Alvarenga de 14 de setembro de 1940. Apud CASTRO, Moacir Werneck de. Mário de Andrade: exílio no Rio. Rio de Janeiro: Rocco, 1989. p. 90. Ver análise de "Girassol da Madrugada" no Capítulo III desta tese.
} 
ninguém na matéria brasileira, constituindo poderoso instrumento de conhecimento. A erótica do conhecimento tem um momento forte no contato físico do eu lírico com o seringueiro:

Seringueiro, seringueiro,

Queria enxergar você...

Apalpar você dormindo,

Mansamente, não se assuste,

Afastando esse cabelo

Que escorreu na sua testa.

O restante da estrofe vai abandonar o conhecimento pelo toque e enumerar o que o poeta sabe do seringueiro: "baixinho, desmerecido, pálido", ao mesmo tempo "cabra resistente". A imagem de um trabalhador rural comum se delineia sem idealização, trazendo a lucidez da visão realista à erótica do conhecimento. Nesse sentido, o elemento erótico na hermenêutica poética de Mário não perverte a lucidez pelo erotismo. Caso fizesse isso, poderia criar uma poesia feita de taras, como "A Morte da Índia", de Augusto Frederico Schmidt, em que o "outro", a índia, é simples receptáculo dos desejos obscuros do sujeito lírico. Mas a erótica em "Acalanto do Seringueiro" faz o caminho do fraterno, do "amor-de-amigo", como dirá no fim do poema. Essa demanda de fraternidade, tentativa de vencer a distância pelo conhecimento afetivo, vai recuperar modos possíveis de identificação:

\footnotetext{
Fomos nós dois que botamos

Pra fora Pedro II...

Somos nós dois que devemos

Até os olhos da cara

Pra esses banqueiros de Londres...

Trabalhar nós trabalhamos

Porém pra comprar as pérolas

Do pescocinho da moça

Do deputado Fulano.
}

Descontada a identificação retrospectiva em relação a Pedro II, que é um modo mistificador de identificação, o restante dos versos é de um despojamento e lucidez social que lembram Brecht. As maneiras pequeno-burguesas do eu lírico, que também 
trabalha, embora seja "poeta do sul", cria um traço de união inédito na poesia brasileira. O sujeito lírico da poesia brasileira, concebido de maneira geral, não se identifica com o trabalhador pelo trabalho comum. E, além desse traço de união inédito, note-se a ausência de pieguismo na concepção de trabalho. Poeta e seringueiro trabalham coletivamente, assumem dívidas coletivamente, para gerar uma riqueza apropriada particularmente. A observação despojada da realidade e que busca traços de fraternidade chega a poetizar involuntariamente a crítica da economia marxista (!). É desses vislumbres simples e pertinentes que a canção se compõe, gerando o fascínio que a tornou uma espécie de unanimidade da crítica. ${ }^{342}$ No entanto, o poeta ainda sente que mesmo a fraternidade do trabalho não gera os vínculos desejados:

\footnotetext{
Porém nunca nos olhamos

Nem nos ouvimos e nem nunca

Nos ouviremos jamais..

Não sabemos nada um do outro,

Não nos veremos jamais!
}

O modo popular da dupla negação adquire uma solenidade inaudita, como se tentasse manter a lucidez na sensação dolorida de uma fraternidade que mal é pressentida e já se evola. A possibilidade de uma intelligentsia, em germe no poema "Colloque Sentimental", mostra-se aqui impossível, pois o poeta não sente uma possibilidade efetiva de comunicação e adesão à esfera popular, embora a desejasse ardentemente. Se o reformismo da classe dominante foi descartado pela atitude de mudança do interlocutor, também este não é acessível. Entre uma classe dominante incorrigível e uma base popular inalcançável, o poeta desespera e sua solução é autocrítica, como se lê na estrofe que segue:

\footnotetext{
Seringueiro, eu não sei nada!

E no entanto estou rodeado

Dum despotismo de livros,
}

\footnotetext{
${ }^{342}$ Um crítico bastante frio em relação ao Modernismo como Nestor Victor, escreve: “o 'Acalanto do Seringueiro' [...] parece-me que é o mais capaz de ser compreendido e admirado pelo geral dos leitores" (VICTOR, Nestor. Mário de Andrade [1928]. Os de hoje. São Paulo: Cultura Moderna, 1938. p. 357). Na outra ponta, o poema despertou entusiasmo particular de Drummond: "Eu aperto a mão que compôs o 'Acalanto do seringueiro' - notável” (SANTIAGO, Silviano (Org.). Carlos \& Mário. Correspondência de Carlos Drummond de Andrade e Mário de Andrade, cit., p. 307).
} 
Estes mumbavas que vivem

Chupitando vagarentos

O meu dinheiro o meu sangue

E não são gosto de amor...

Me sinto bem solitário

No mutirão da sabença

Da minha casa, amolado

Por tantos livros geniais,

"Sagrados" como se diz...

E não sinto os meus patrícios!

E não sinto os meus gaúchos!

Seringueiro, dorme...

E não sinto os seringueiros

Que amo de amor infeliz!...

Com a impossibilidade de uma palavra que propicie a comunicação do poeta com o seringueiro, é o próprio fundamento intelectual do poeta que entra em xeque. Monta-se então uma dicotomia: conhecimento pelo livro e conhecimento pelo amor, o que põe no centro da questão a função da cultura na sociedade brasileira, segundo a visão desse poema. A cultura, "despotismo de livros", isola e não une, seu sentido é antifraterno. A intransitividade da cultura, da literatura, do homem de letras ou mesmo do intelectual engajado em relação aos trabalhadores brasileiros - afinal, o seringueiro nada mais é do que uma modalidade extrema do proletariado rural brasileiro - revela, pelo negativo, o funcionamento incompleto da cultura, mesmo da mais progressista, no Brasil.

Se o seringueiro não pode ser alcançado pelo poeta, o próprio poeta não tem fundamento na vida brasileira. Se não há a palavra que universalize a humanidade do poeta, palavra que "torne manifesto algo de não distorcido", 343 é o próprio ideal de lírica que se torna questionável no Brasil. A não imediatidade do sentimento de humanidade entre os homens brasileiros repõe de forma drástica uma herança colonial: a divisão social entre homens que são considerados homens, de acordo com o padrão da civilização, e homens que são considerados coisas, objetos não humanos. O que o poeta revela, de modo especificamente poético, é a persistência da herança escravista no Brasil pós-abolição. Essa herança nasce fundamentalmente de uma sociedade baseada em homens animalizados, como diz um analista da obra de Caio Prado Jr.: "O principal,

\footnotetext{
${ }^{343}$ ADORNO, Theodor W. Palestra sobre lírica e sociedade, cit., p. 66.
} 
e pior, impacto da escravidão é negar ao trabalhador sua humanidade". ${ }^{344}$ Os "restos e relações escravistas ou semiescravistas" se mantêm, tornando-se uma espécie de ética arraigada e traço psicológico fundamental. Esse "modo de ser" brasileiro ao mesmo tempo compõe e resulta de uma matriz prática: "O que de mais importante se mantém da grande exploração é uma certa maneira de se tratar o trabalhador, identificado como praticamente o equivalente a um instrumento de trabalho. Dessa forma, o assalariado, que veio substituir o escravo com a abolição, encontrou o mesmo ritmo produtivo e estrutura econômica que existiam na época anterior". ${ }^{345}$ Como poesia, o "Acalanto do Seringueiro" surpreende esse estado de coisas justamente porque seu propósito é outro. O poeta não quer desvendar as fraturas de uma sociedade pouco humana, seu objetivo é estender e complementar uma humanidade profundamente sentida e mesmo transbordante. Partindo de um propósito de amor universal, o que se lhe depara é a impossibilidade de comunicação, a inexistência de uma linguagem que torne os homens reconhecíveis e comunicáveis. O que se afigura impossível é justamente a característica fundamental da universalidade da poesia lírica: ser a expressão individual de uma corrente coletiva subterrânea. ${ }^{346}$ Bloqueado o caminho da comunicação pela linguagem poética, o poeta vai buscar a integração por caminhos mágico-míticos:

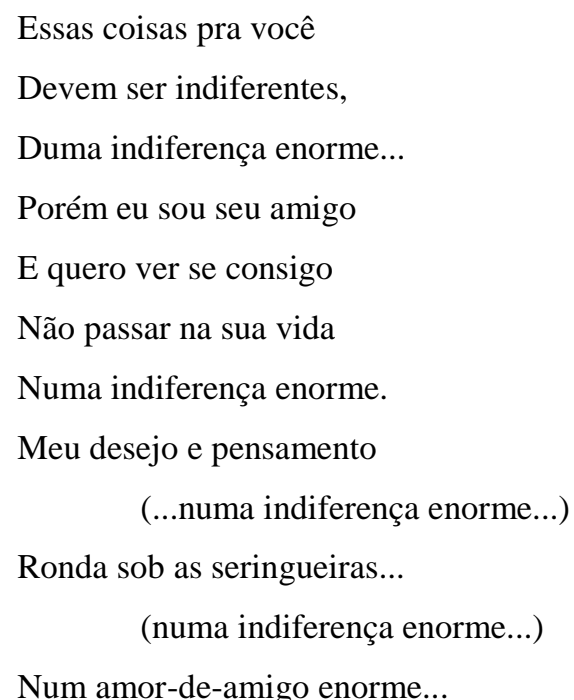

Seringueiro, dorme!

\footnotetext{
${ }^{344}$ RICUPERO, Bernardo. Caio Prado Jr. e a nacionalização do marxismo no Brasil, cit., p. 143.

${ }^{345}$ RICUPERO, Bernardo. Caio Prado Jr. e a nacionalização do marxismo no Brasil, cit., p. 186. E ainda: "O principal efeito dos resíduos escravistas é impedir a integração da maior parte da população brasileira à vida nacional" (p. 186).

346 "Uma corrente subterrânea coletiva é o fundamento de toda lírica individual" (ADORNO, Theodor W. Palestra sobre lírica e sociedade, cit., p. 77).
} 
Num amor-de-amigo enorme

Brasileiro, dorme!

Brasileiro, dorme.

Num amor-de-amigo enorme

Brasileiro, dorme.

Brasileiro, dorme.

Brasileiro... dorme...

Brasileiro... dorme...

Esse é o final do poema. A tentativa de superar a "indiferença enorme" oferece ao poeta, por um paradoxo, a fórmula exata das relações sociais brasileiras, que se dão "numa indiferença enorme". O achado poético se infiltra pelos versos, impedindo que o "amor-de-amigo enorme" o supere. A impossibilidade de resolução fraterna pelo meio lógico-racional da linguagem, mesmo pela lógica particular da linguagem poética, vai aflorar na linguagem a solução mágico-mítica. Os versos das duas estrofes finais já não são mais um acalanto, são a busca de uma integração anestésica, no caminho da fusão mágica. A repetição constante de "brasileiro, dorme" no ritmo balouçante da redondilha vai gerar uma hipnose. A solução se dá no âmbito das divindades míticas Hypnos e Morfeus, cuja família é completada por Tânatos. A hipnose e o sono, aparentadas à morte. É como se o poeta, finalmente, criasse uma igualdade brasileira pela hipnose, o que já não é mais uma fraternidade, mas uma fusão mágica. Poeta e seringueiro podem, enfim, se juntar em uma anestesia hipnótica. Assim, o "Acalanto do Seringueiro" é um acalanto solidário da solidariedade impossível. A identificação nacional se abriga no torpor da hipnose e no sono. É quase uma igualdade nacional na morte. A morte, a hipnose e o sono: onde todos os brasileiros se encontram e confraternizam. No fundo, é um tristíssimo poema da impossibilidade, uma "canção do impossível". Ela esgota o estranhamento cordial e o exaspera, chegando a um ponto de saturação, que antecede a ruptura. 


\section{Culpa e Autodestruição}

As dificuldades de comunicação com o "outro" presentes nos dois "Poemas Acreanos" são incorporadas na forma de "O Carro da Miséria", longo poema feito e refeito por Mário, cujas redações fundamentais datam de fim de 1930 e fim de 1932 , com uma revisão em 1943. Dentre os poemas de Mário, ele forma, com alguns poemas da seção "Grão Cão de Outubro", de A costela do Grã Cão, o grupo de poemas menos convidativo à análise e interpretação crítica. E a fortuna crítica sobre "O Carro da Miséria" quase inexiste, sendo composta apenas de curtos comentários, como os de Lafetá e José Paulo Paes. ${ }^{347}$ Os únicos comentários longos que fazem a exegese do poema e, de certa forma, o tornam interpretável, são textos do próprio Mário de Andrade: um "Ensaio de interpretação" incompleto e uma longa carta a Carlos Lacerda, de 5 de abril de $1944 .{ }^{348}$ A partir das palavras do poeta, é possível uma tentativa de aproximação de "O Carro da Miséria", pois a maior dificuldade que o poema apresenta é o fato de ele ser construído com um tipo de hermetismo especificamente mariodeandradiano, de base psicológica, que para expressar movimentos antagônicos e simultâneos da consciência do poeta, utiliza, em maior ou menor grau, palavras que não significam nada. Como o próprio poeta diz em "Ensaio de interpretação de 'O carro da Miséria": "eu botei mesmo, no poema, elementos que não querem dizer coisíssima nenhuma, que proposital, voluntária e... inconscientemente nada significam, não tem sentido interpretável". ${ }^{349}$ Mesmo assim, o afastamento da crítica mariodeandriana de uma explicação mais detalhada é tanto mais grave pelo fato de o poema em questão ocupar o centro do conflito sociopolítico do sujeito lírico de Mário. Nesse contexto, uma análise exaustiva, ou mesmo totalizadora em sentido acadêmico, seria aqui impossível, pois, para tentar esgotar o fenômeno poético que é "O Carro da Miséria", poema constituído de 16 partes, de tamanho irregular, variando de 2 a 56 versos, precisaríamos de uma tese inteira só sobre ele. O que pretendo fazer, então, nas linhas que seguem é uma abordagem de perspectiva, um corte transversal no poema, para

\footnotetext{
347. LAFETÁ, João Luiz. 1930: a crítica e o modernismo. São Paulo: Duas Cidades/Editora 34, 2000. p. 209 e PAES, José Paulo. Sobre "O Carro da Miséria". Revista do Instituto de Estudos Brasileiros, n. 36. São Paulo: IEB, 1994.

${ }^{348}$ Ambos reproduzidos em PAES, José Paulo. Sobre "O Carro da Miséria", cit.

${ }^{349}$ ANDRADE, Mário de. Projeto de ensaio de interpretação. In: PAES, José Paulo. Sobre "O Carro da Miséria”, cit., p. 177.
} 
entender o desenvolvimento das percepções do sujeito lírico mariodeandradiano sobre o seu lugar social.

Como um modo de o poeta tentar engajar a forma modernista na realidade social brasileira, viemos acompanhando suas relações com um "outro": o burguês, o aristocrata, o seringueiro, tendo em conta a diferença de peso de cada uma dessas alteridades em sua poesia. Em nenhum desses momentos, o eu lírico alcança uma transitividade social, cujo resultado na subjetividade lírica é tanto mais agudo quanto mais ela é ansiada, como vimos em "Acalanto do Seringueiro". Agora, destituído de uma alteridade social possível, ${ }^{350}$ surge uma alteridade mais drástica: a alteridade no interior da própria subjetividade. $\mathrm{O}$ poeta percebe em si mesmo um antagonismo de consciência. Em termos formais, a consciência em conflito explode em uma pluralidade de manifestações. Há, ao longo do poema, uma variedade de formas poéticas, disposições e situações do eu lírico, modos da sensibilidade, soluções de linguagem diversas e interessantes em si mesmas, ${ }^{351}$ mas não será possível acompanhá-las em uma análise tradicional: verso a verso, parte a parte, deduzindo o todo e, então, resignificando as partes. Os problemas que abordarei são os da solução geral da linguagem, da lógica poética e da forma do eu em seu conflito sociopolítico.

A dificuldade de comunicação poética com uma alteridade vai ser não apenas um tema mas também a forma de um hermetismo estético, da dificuldade de encontrar o ponto exato em que o engajamento é possível. A formalização poética de uma linguagem intransitiva leva à deformação da linguagem, como se o poema expusesse uma configuração geral deformada, anômala. ${ }^{352}$ Essa anomalia da linguagem, que a seu modo organiza um mundo constituído de anomalias que se apresentam e se multiplicam, tem um referencial subjetivo que o próprio poeta indica quando fala do "assunto do poema":

\footnotetext{
${ }^{350}$ A alteridade será talvez possível no plano amoroso, como vimos nos "Poemas da Negra", mas ainda assim, essa transitividade é perpassada por um sentimento de consolação - que já é uma desistência de transitividade social - e de uma existência espectral dos amantes, de uma essencialidade incorpórea.

${ }^{351}$ Por exemplo, em relação ao conflito social: há soluções amorosas (parte I), soluções utópicas (parte XV), momentos de revolta (parte XII), momentos de desistência (parte VIII), momentos de autocrítica (parte XIII). Há disposições da sensibilidade: confessionais (parte I), distanciamento e autocrítica (parte VIII), autoironização (parte V). As perspectivas formais também mudam, usando formas do verso livre confessional ou corrosivo na maior parte do poema, formas populares como o coco (parte II) e o cordel (parte III), formas da canção (parte XIV).

${ }^{352}$ No curto comentário sobre o poema de LAFETÁ, João Luiz. 1930: a crítica e o modernismo, cit., p. 209, ele fala de "destruição sistemática da linguagem". Nesse comentário, a linguagem problemática do poema é apontada com acerto, mas a rapidez com que o crítico conclui que o poeta faz uma síntese bemsucedida de projeto estético e projeto ideológico afasta o centro problemático do poema em favor do argumento de seu livro.
} 
E esse assunto do poema, que agora vai esclarecer o sentido dele todo e de numerosos versos e mesmo partes inteiras dele, é a luta do burguês gostosão, satisfeito das suas regalias, filho-da-putamente encastoado nas prerrogativas da sua classe, a luta do burguês pra abandonar todos os seus preconceitos e prazeres em proveito de um ideal mais perfeito. Ideal a que a inteligência dele já tinha chegado por dedução, lógica e estudo, e que a noção moral aprovava e consentia, mas a que tudo o mais nele não consentia, não queria saber. Simplesmente porque estava gostoso. ${ }^{353}$

O problema da linguagem, linguagem que em poesia é uma forma de organizar a subjetividade e o mundo, tem aqui como "assunto" a consciência de classe. ${ }^{354}$ Mais propriamente, a linguagem documenta o conflito em um processo de mudança de aliança de classes do poeta, dos "prazeres, preconceitos e prerrogativas" de sua classe burguesa ao "ideal mais perfeito" comunista. É o próprio Mário de Andrade o "burguês gostosão" do trecho citado. Em termos de luta política, a princípio, o raciocínio de Mário nessas linhas parece um pouco turvo. Em primeiro lugar pelo direcionamento moral das questões, em que o burguês, mais do que classe dominante, é um "maucaráter”, e o comunismo, em vez de ser uma conclusão lógica das contradições sociais, é um "ideal mais perfeito", quase se diria uma obra de arte social. No entanto, essa aparente falta de clareza política é o reflexo de uma formação social gelatinosa na base e de um conflito de interesses restritos e personalistas no topo. Explorando um pouco mais o texto interpretativo do próprio Mário, ele diz que a motivação do poema foi a decepção idêntica e consecutiva com duas revoluções, a de 1930 e a de 1932, que transparece em "O Carro da Miséria" no verso da parte XVI, "Não foram esses heróis heróis revolucionários". Não é o caso aqui de refazer a história dessas revoluções, mas de acompanhar como Mário as sentiu e entendeu, e como ele formalizou poeticamente esse conflito. Em relação à Revolução de 30, ele relata em carta a Lacerda sobretudo seu sofrimento pelo lado familiar e de decepção com amigos. ${ }^{355}$ Mas sobre a Revolução

\footnotetext{
${ }^{353}$ ANDRADE, Mário de. A Carlos Lacerda. In: PAES, José Paulo. Sobre “O Carro da Miséria”, cit., p. 181.

354 Sobre a diferença de "assunto" e "tema" em poesia, ver ANDRADE, Mário de. Castro Alves [1939]. Aspectos da literatura brasileira. Belo Horizonte: Itatiaia, 2002. "O assunto, em poesia, tem de ser o que é a melodia infinita em música, um elemento geral e genérico, dentro do qual os movimentos do ser vagueiam entre descaminhos, encruzilhadas, quedas em abismos, vagabundagens de sentimentos, ideias, juízos. Ao passo que o tema em poesia é a restrição do assunto a um ponto só da sua caminhada, da mesma forma que em música é um elemento curto retirado da melodia” (p. 140).

${ }^{355}$ ANDRADE, Mário de. A Carlos Lacerda. In: PAES, José Paulo. Sobre "O Carro da Miséria”, cit., "Eu sofrera muito do lado 'família' com a revolução" (p. 179).
} 
de 32, que literalmente invadiu a vida pessoal do poeta, ele faz uma observação sobre o engajamento das classes sociais nela, em carta a Drummond, que vale a pena transcrever:

Não esqueço que o voluntariado podia ser maior, que a classe proletária, tanto rural como urbana, deu pouca contribuição militarista. Dos quase duzentos mil operários de fábrica paulistas, muitos trabalhados pelo comunismo, a contribuição de voluntários pra guerrear não foi mínima, foi nula. Mas toda a gente aceitava fabricar engenhos de guerra. Os comunistas partidários que querem fazer da guerra paulista um movimento exclusivamente burguês mentem por pragmatismo, no seu já famoso pragmatismo que no Brasil se transformou notoriamente em licença pra todas as safadezas. A pequena burguesia, assimilável ao proletariado, com a única diferença de ganhar por mês o pão que o proletariado ganha por dia, a pequena burguesia, que tem seus ideais pouco acima de pão e dormida, entrou com violência sentida na guerra. ${ }^{356}$

Se evidentemente não se pode entender a Revolução de 32 como um combate em favor dos interesses do proletariado, e de se tratar de fato de um conflito oligárquico-burguês, a ausência de uma resposta clara e objetiva da práxis proletária, que interpretasse e se posicionasse de maneira convincente diante de um conflito de proporções nacionais, e aproveitasse a época agitada para aumentar seu raio de ação sociopolítica, mostra as deficiências de visão, organização e atuação dos representantes da classe operária nesse momento da história brasileira. Havia classes bem definidas, como o comentário de Mário demonstra, mas a história brasileira de então não se movimenta pela luta de classes, mas pela luta de interesses no topo, a que o proletariado organizado assiste "pragmaticamente". Nesse quadro, a lucidez do intelectual burguês que era Mário de Andrade perde os pontos de apoio para uma reflexão crítica de longo alcance e um posicionamento político à esquerda. Contudo, o que se monta na obra de Mário nesse momento é uma dualidade entre pensamento e atuação. Se o pensamento busca entender analiticamente as contradições sociais e amarga psicologicamente seus efeitos, a atuação é de completa adesão à causa paulista, de caráter emocional como foi, mas de natureza enfática. Assim, estamos diante de uma ambivalência de biografia e obra que é preciso ultrapassar. Se biograficamente Mário se entrega à causa paulista, quase como

\footnotetext{
${ }^{356}$ Carta de 6 de novembro de 1932. SANTIAGO, Silviano (Org.). Carlos \& Mário. Correspondência de Carlos Drummond de Andrade e Mário de Andrade, cit., p. 425. Não encontrei documentação sobre a interpretação proletária da Revolução de 32. A mais ampla documentação dos interesses das classes nesse período de 1930-1937 está em CARONE, Edgard. A segunda República (1930-1937). São Paulo: Difel, 1974.
} 
em um dionisismo político, num transe de participação política em sua comunidade paulista, em "O Carro da Miséria" não há adesão a causa alguma, mas um longo e doloroso processo de mutilação psicológica e destruição da linguagem. São dois transes de sentido diferente: o transe participativo do homem e o transe autodestrutivo da obra. O primeiro explica-se pela solidariedade a familiares e amigos, já o segundo é preciso explicar com mais detalhes.

Destituído dos componentes sociais ${ }^{357}$ que propiciariam uma reflexão materialista propriamente dita, e sem querer abandonar um pensamento crítico e fraterno, Mário vai moralizar e internalizar essas questões. Ele se lança, assim, como "suplente de um sujeito social", "358 ausente, o sujeito social revolucionário. A decepção com as revoluções deixam claro ao poeta que as classes que as lutam não estão à altura de sua exigência, que seria necessária outra força histórica, mais justa, capaz de realizar um "ideal mais perfeito". Nesse sentido, o que parece entendimento turvo da luta política se mostra como o esclarecimento possível diante de uma situação social ela própria turva. No entanto, esse movimento de suplência do sujeito mariodeandradiano, adesão revolucionária no plano da imaginação, se choca com a lucidez quanto à própria posição no processo histórico, como um sujeito histórico determinado e preso no jogo de interesses das classes do topo. Nesse nível, ele é um sujeito histórico "emparedado" em sua condição de classe, o que o poeta sente em outros poemas como um isolamento enorme. "O Carro da Miséria", então, dentro do que pôde ser sondado do projeto de interpretação do próprio poeta e de suas implicações, responde a esse movimento da consciência simultâneo e antagônico, de crítica histórica e reconhecimento de si como parte da história criticada. ${ }^{359}$ Daí o hermetismo e as deformações que o poeta impõe aos seus versos. Podemos agora verificar a presença dessas questões na parte I do poema:

\footnotetext{
357 Chamo de "componentes sociais" as organizações de grupos e de classes bem definidas que participassem de um conflito e de um processo histórico-social inteligíveis. São "componentes sociais" que estavam claras, em outro contexto, para o Lukács de História e consciência de classe, cuja primeira edição é de 1922.

358 Adapto para meus propósitos uma expressão que está em ADORNO, Theodor W. O Artista como Representante. Notas de literatura I, cit., p. 164. Nesse texto do filósofo sobre Valéry, ela significa o "homem completo e indiviso", o "sujeito completo" no qual "a sina da cega individuação fosse cancelada".

359 "Como criação, como formação e existência eu sou burguês 'da pior burguesaria"” (ANDRADE, Mário de. Projeto de ensaio de interpretação. In: PAES, José Paulo. Sobre "O Carro da Miséria”, cit., p. 178).
} 
O que que vêm fazer pelos meus olhos tantos barcos

Lenços rompendo adeuses presentinhos

Cherangas na terra-roxa das estações um grito

Um grito não um gruto

Que me faz esquecer a miséria do mundo pão pão

O que que vem fazer na minha boca um beijo

A mulher da Bolívia agarrando

Um penacho de viúvas restritas

Restritas não restrutas

Que o papagalo repassa e põe na vida...

Ah... caminhos caminhos caminhos errados de séculos...

Me sinto o Pai Tietê. Dos meus sovacos

Saem fantasmas bonitões pelos caminhos

Penetrando o esplendor falso da América.

Dei-vos minas de ouro vós me dais mineiros!

Glória a Cícero nas vendinhas alterosas

Com a penugem dos pensamentos sutis

Feito ninho de guaxe

O passado atrapalha os meus caminhos

Não sou daqui venho de outros destinos

Não sou mais eu nunca fui eu decerto

Aos pedaços me vim - eu caio! - aos pedaços disperso

Projetado em vitrais nos joelhos das caiçaras

Nos Pirineus em pororoca prodigiosa

Rompe a consciência nítida: EU TUDOAMO.

Ora vengan los zabumbas

Tudoamarei! Morena eu te tudoamo!

Destino pulha alma que bem cantaste

Maxixa agora samba o coco

E te enlambuza na miséria nacionar

Há uma dualidade estrutural que atravessa essa primeira parte, que já contém em si parte substancial do "assunto" do poema. Algumas referências poéticas são palpáveis e 
prestam-se ao estudo da relação forma-conteúdo, outras são expressões-palavras, como disse o poeta, ${ }^{360}$ e podem ser analisadas em sua "fenomenologia", no papel que desempenham no poema, mas não possuem imanência poética, elas são indícios formais de significados que vivem na psicologia do poeta, na forma da subjetividade, e não na forma do poema. As duas estrofes iniciais fazem parte desta última característica. "Barcos, adeuses, presentinhos, charangas, terra-roxa, beijos, mulher da Bolívia, viúvas, papagalo" são palavras e imagens que podem ser exaustivamente estudadas em suas implicações, sugestões e significados, sem que se modifique o fato fundamental de que no poema elas são índices da consciência dilacerada, que é o significado essencial dos versos. $^{361}$ As palavras são menos palavras do que gestos psicológicos. Em sua significação geral, o gesto psicológico dessas duas estrofes iniciais é o espírito de "voume embora", ou "voumemborismo", 362 que Mário identificou em seu ensaio "A poesia em 1930", um estado de espírito de poetas que, "incapazes de achar a solução, surgiu neles essa vontade amarga de dar de ombros, de não se amolar, de partir pra uma farra de libertações morais e físicas de toda espécie". ${ }^{363}$ Mas a presença desse estado de espírito no início de "O Carro da Miséria" é sentida com espanto, expresso na expressão popular "o que que vem fazer". Não só a consciência participante de Mário rejeita intuitivamente essa vida de libertações morais e físicas, que, no entanto, é essencialmente a sua, pela suas "prerrogativas de classe", como imprime a rejeição na desarticulação da linguagem: "um grito não um gruto", "restritas não restrutas". A deformação, repetida como um leitmotiv estruturante, é a revelação dessa simultaneidade: a realidade da vida imoral e o grito de desespero da consciência moral. A terceira estrofe, mais lógica em sua estruturação poética, faz a suma da realidade do "burguês gostosão": por caminhos errados, bonitão, penetrando o esplendor falso da América. São esses versos que Manuel Bandeira chama de "enormes e admiraveíssimos". ${ }^{364}$ De fato, essa imagem de um espectro mítico se engalanando na

\footnotetext{
360 "Está claro que certas palavras, certos vocativos, por mais que eu me psicanalise, não consigo descobrir donde me vieram, 'viúvas', 'a mulher da Bolívia', por exemplo. Mas vibram como palavras, são expressões-palavras que me parecem sugestivas e por isso deixei elas assim mesmo" [grifo meu] (ANDRADE, Mário de. A Carlos Lacerda. In: PAES, José Paulo. Sobre "O Carro da Miséria”, cit., p. 182).

361 "Charanga" é a antiga banda militar formada por instrumentos de sopro; "papagalo", ao que parece, é a forma latinizada-deformada de "papagaio".

${ }^{362}$ Termo usado por CAMILO, Vagner. Drummond: da rosa do povo à rosa das trevas. São Paulo: Ateliê Editorial, 2001. p. 86.

363 ANDRADE, Mário de. A Poesia em 1930 [1931]. Aspectos da literatura brasileira, cit., p. 42

${ }^{364}$ Carta de 21 de janeiro de 1933. In: MORAES, Marco Antônio (Org.). Correspondência Mário de Andrade \& Manuel Bandeira, cit., p. 549. Mário mais de uma vez repete o elogio recebido quando diz
} 
riqueza falsa da América, em expressão solene com breves quebras coloquiais é um primor de elaboração poética. Note-se, então, essa característica do "transe de inspiração"365 que está na base do poema: ele participa a um tempo de uma linguagemíndice, sem significação imanente, e de uma linguagem poética finamente elaborada, de extraordinária imanência, em um todo em que essas partes se justapõem para gerar uma mutilação poética generalizada. Mutilação que já aparece formulada na quarta estrofe, mescla de expressões-palavras e significações poéticas. Nessa estrofe, a confusão dos quatro primeiros versos convive com a lucidez do restante da estrofe. O espírito de "vou-me embora" sofre um refluxo, e a consciência participante aflora. Mas nesse refluxo, a mutilação se mostra no corpo. A dilaceração da consciência entre os Pirineus europeus e as caiçaras nacionais reaparece, por sua vez, produzindo a bela imagem dual de pedaços de corpo que caem e estão projetados em vitrais. A dilaceração do corpo no chão e da alma nos vitrais inicia a mais desenvolvida das formulações dionisíacas de Mário: corpo e alma se dilaceram, como se morressem, em seguida entram em uma convulsão telúrica, a "pororoca prodigiosa", e renasce na consciência nítida que rompe: "EU TUDOAMO", de um enfático engajamento social unanimista. O ciclo morteressurreição do dionisismo é seguido passo a passo, com palavras e imagens poéticas precisas. Um momento alto da poesia de Mário, sem dúvida. E a consciência nítida, que na verdade é a consciência nítida da imersão no mito, dissolve-se em música e dança, que, por sua vez, são a expressão poética, segundo Mário, do seu engajamento. O poeta afirma que a "ideia-refrão básica" do conflito do poema é: "Ora vengan los zabumbas/Mas eu não quero estes zabumbas", ${ }^{366}$ que pode ser traduzida mais ou menos como: "Que venha a explosão da revolução social/Mas eu não quero essa explosão". As palavras em espanhol trazem um tipo de deformação ao verso, em que "zabumba" é a expressão-palavra para o engajamento comunista. E segue a explicação do poeta: "Porque 'zabumba'? A explicação é facílima em mim: é a constância coreográficodionisíaca que atravessa toda a minha poesia, e pra qual o Roger Bastide já chamou a atenção. Em todos os grandes momentos extasiantes, na dor ou na alegria, eu 'me

que, segundo Manuel Bandeira, “'O Carro da Miséria' contém alguns dos versos mais bonitos que já inventei" (ANDRADE, Mário de. Projeto de ensaio de interpretação. In: PAES, José Paulo. Sobre "O Carro da Miséria", cit., p. 177).

${ }^{365}$ Expressão de José Paulo Paes. (Sobre "O Carro da Miséria", cit., p. 176).

${ }^{366}$ ANDRADE, Mário de. A Carlos Lacerda. In: PAES, José Paulo. Sobre "O Carro da Miséria", cit., p. 181. "Zabumba" pode significar bumbo, ou cuíca. Na continuação do texto, Mário escreve que "acerta a mão" dessa "ideia-refrão básica” só "na XVa parte: ‘Estes zabumbas eu quero!”” (p. 181). 
dissolvo em dança". ${ }^{367}$ Dos muitos significados dessa passagem, quero chamar a atenção para o fato de "zabumba" ser simultaneamente a dissolução no dionisíaco e a decisão pelo engajamento social. Dado o entroncamento insolúvel da matéria históricobiográfica do poeta que expusemos mais acima, a sua solução na obra poética é $a$ ativação do mito para que a participação social faça sentido. A solução mítico-mágica do poema, então, é menos uma idiossincrasia do poeta do que uma solução formal que nasce da necessidade do poeta de organizar e dar sentido a uma matéria históriconacional crispada. Uma vez reconhecida a originalidade da solução que Mário de Andrade dá ao "assunto" do poema, e que perpassa com diferentes matizes todas as suas dezesseis partes, será necessário ainda chamar a atenção para uma forma particular dessa solução mítico-engajada. A fórmula "EU TUDOAMO” da primeira aparição do mito dionisíaco é um momento excepcional de êxtase, uma explosão que desafoga o sofrimento horrível que motiva o poema. Porém, esse engajamento unanimista, ${ }^{368}$ que remonta à herança pré-modernista e dos inícios do Modernismo de Mário, é insuficiente, e ela não voltará mais no poema. Ao contrário, o ciclo morte-ressurreição está presente no poema todo em três níveis: da linguagem, da subjetividade lírica e da significação geral do poema. Nos três níveis há mutilações e destruições, cuja promessa de renascimento está necessariamente implicada, como provam os dois últimos versos do poema (em que a Tia Miséria pode parir a "nossa exatidão"). De particular importância é entender o modo como esse dionisismo se dá no nível da subjetividade lírica, e essa configuração pode ser analisada em duas partes do poema, na parte VIII e na parte XIII.

\section{VIII}

Nas ondas do mar eu vou

Tenho medo de morrer

Si eu soubesse que morria

Nas ondas no mar não ia.

\footnotetext{
${ }^{367}$ ANDRADE, Mário de. A Carlos Lacerda. In: PAES, José Paulo. Sobre "O Carro da Miséria”, cit., p. 181-182.

368 "Unanimismo" é um termo criado por Jules Romains, que seguiria uma linhagem poética de democracia universal e amor fraterno entre os homens. Ligada ao surgimento do verso livre, sua história acompanha o fio Victor Hugo-Whitman-Jules Romains-Émile Verhaeren e exerce influência significativa na poesia modernista de Apollinaire, ver Capítulo I desta tese, p. 47.
} 
Geme por sobre mim

O grande torpe esfacelado

Âncoras caem feito lágrimas

Do meu amor que se acabou

Mergulho no ão do vendaval.

... toda essa multidão de caminhos malditos

Por onde puxo o Carro da Miséria feito boi

Eu boi? Eu cobra! não! que eu sou gaúcho

Cuera na dignidade e na zangueza!

Viúvas restritas restrutas restritas

Venham amostrar a obrigação do poeta

Que range e come as próprias tíbias do naufrágio

Venham escutar o canto das jangadas

E a tropilha em rancor cegar meus gritos

Traíras velozes rombos infinitos

Maravilhas de Europa e arranhacéus...

No fundo eu choro como um mamote safado

No fundo eu choro como um safadíssimo chupim.

Viúvas restritas viúvas da Bolívia

Venham explicar a obrigação do poeta

Assanhadas coitadinhas dessas madres

Por me encontrarem constipado.

Como é natural do mito, ele retorna ciclicamente, e a configuração de linguagem e significados da parte I está presente novamente na parte VIII: do sentimento de "vou-me embora" à imersão no conflito de consciência, e desse conflito à autodilaceração. Contudo, a subjetividade, em vez do despedaçamento que inicia o mito dionisíaco da parte I do poema, assume aqui formulação mais drástica. A má consciência do intelectual burguês que puxa o "Carro da Miséria" assume um ponto de lucidez inédita na poesia brasileira até então, e sem compaixão ou condescendência consigo, passa à autoagressão. Observamos um sujeito lírico com sentimento de culpa, e que resolve esse sentimento pela agressão a si mesmo, o "héautontimourouménos", ou "o algoz de si 
mesmo", trazido para a lírica moderna por Baudelaire. ${ }^{369}$ Em vez do "eu em pedaços" e da "pororoca prodigiosa", encontramos o "mamote safado" e o "safadíssimo chupim", que o poeta declara ser. O refluxo do espírito de "vou-me embora" encontra um poeta que adquire consciência de si e se odeia, que se percebe e se rejeita. O desenvolvimento desse aspecto na última estrofe é o sarcasmo, que desenvolve a lógica de mutilação do poema, em que mesmo a autoagressão não se completa porque é mutilada pelo sarcasmo. A formulação dolorosa de autoagressão e sarcasmo reaparece na parte XIII:

\section{XIII}

Enquanto o mundo for mundo

Enquanto o sal for compra-e-venda

Enquanto a vida vier com injeção de éter

Enquanto o poeta tiver

Vetiver cabeça tronco e membro

Os milagres farão chuvas de astros nos sonhos

O amor há-de ser tudo e a carícia dos pratos

Além de alimentar despertará prazer...

Chorar é bom, rir bim, raivar é bão pão pão

Mas im miu páito as núvoas dus absentos

Não puderão tir mais dulçuras de mulatras

Nem o soave gimir das brises do caqueiral.

Torpe é a cidade. Um desejo sombrio de estupro

Um desejo de destruir tudo num grito

Num grito não num gruto

E dar um beijo na mão de quem trabalha...

E si o Fulano for maneta?

Ora brinque-se senhor adevogado

Diga adeus e vá pro Diabo que o carregue

Que eu também já vou saindo

Pro galo poder cantar.

\footnotetext{
${ }^{369}$ Ver poema "Le Héautontimouroménos", de Baudelaire. Sobre a configuração dessa questão em Drummond, ver CAMILO, Vagner. Drummond: da rosa do povo à rosa das trevas, cit., especificamente o item 6 da Parte III: Drummond Héautontimorouménos: Culpa Social.
} 
O privilégio do éter, do sonho, da comida cariciosa e do prazer: modos exemplares do "burguês gostosão" da primeira estrofe são passados por um travo crítico na segunda, em que a deformação da linguagem dá a nota de sofrimento na renúncia das prerrogativas de classe. A perspectiva é autoirônica, e o poeta se vê com sarcasmo e se tinge de ridículo. Mas na estrofe seguinte há um crescendo de violência, de uma violência que adquire conotação sexual predatória e se dirige para fora do poeta, para a cidade. A destruição da cidade seria contrabalançada pelo "beijo em cada mão que trabalha...". Até aqui, o poema faria ideologicamente uma regressão, pois a crítica ganharia uma conotação de paternalismo católico, contra a corrupção do mundo e pela santidade do trabalho. “Abençoados os humildes...". E a destruição, de um dionisismo mítico-engajado, agressivo e purificador, se passaria para uma sagrada destruição católica, derrubando a Babilônia e levantando Jerusalém. Porém, ao contrário disso, e aumentando a voltagem do sarcasmo, a blague da última estrofe segue a lógica de mutilação do poema e desmorona o edifício do paternalismo católico, que de edificante se transforma em ridículo. Os sentimentos sarcásticos e agressivos se expandem pelos versos como um contágio, de que mesmo o poeta é portador, e ele mesmo deve sair de cena, para o "galo poder cantar", símbolo da nova aurora, do mundo novo a surgir, seja mítico-dionisíaco, seja político-revolucionário - ou os dois, pela lógica do poeta. A simultaneidade da consciência que ao mesmo tempo participa da ordem burguesa que critica assume um tom radical e se submete a um processo autodestrutivo. Para atingir a solução mítico-engajada, que no plano do mito permite o "EU TUDOAMO", no plano histórico-social será necessário que a existência da subjetividade lírica do poeta, com toda a história social nela cristalizada e que ela pressupõe, seja posta em perspectiva, compactada em todo o seu significado, e sofra uma expiação destrutiva. O sentido radical do dionisismo de Mário de Andrade produz uma visão da história brasileira em que ela não pode ser transformada, modificada ou revolucionada sem que passe por um rigoroso processo destrutivo e expiatório, propriamente purificador, para que possa viver uma nova vida. E esse processo destrutivo não se faz por um elemento vindo de fora, mas por uma tensão apreendida no movimento do processo histórico. A linguagem do poeta, suas imagens e referências, bem como suas disposições de espírito, são construídas com elementos brasileiros, estão inseridas, ainda em negativo, no ciclo do nacionalismo modernista. O processo de destruição é uma depuração da própria experiência de si e do Brasil, e surge ainda como possibilidade de formação, como o 
sonho da boa individuação, mas formulado de maneira intrincada e radical: o potencial de reflexividade brasileira que lateja sob o sentido predatório e cego de nossa história só poderia vir à tona se rompesse com todos os pressupostos que a constituem, incluído o que dela já é parte constitutiva do poeta. Esse potencial de reflexividade, então, é um tipo de efeito colateral, uma anomalia que se abre entre um ciclo e outro de nossas modernizações reacionárias, e que, por sua própria fugacidade, assume uma feição convulsiva, agônica, pois mal ela pode ser vislumbrada e já começa a se tornar distante e opaca. $^{370}$ A esse espectro de reflexividade, o poeta vai dar visibilidade, paradoxalmente, pelo mito - o que explica que o dionisismo e o sacrifício em sua poesia surjam da própria matéria brasileira, e não de uma imposição exterior.

A última revisão de "O Carro da Miséria” ocorre no fim do ano de 1943, o que o coloca na vizinhança das últimas produções poéticas de Mário. Além da cronologia, há a afinidade do espírito autocrítico em busca de um engajamento social válido presente no poema e nas obras de Mário dos anos 1942-1945. Da perspectiva da continuidade dos problemas poéticos, devemos observar que o último capítulo desse engajamento difícil está em "A Meditação sobre o Tietê". Aqui, o sentido expiatório e destrutivo percorre todo o poema, que expõe em detalhes o sufocamento do potencial renovador, crítico e transformador da poesia de Mário por uma força mítica, poderosa e cega - o mana da história brasileira. ${ }^{371} \mathrm{O}$ sentimento que o poeta tem de si próprio em "A Meditação sobre o Tietê" recupera a cisão da consciência exposta em "O Carro da Miséria”, mas já não é uma percepção da má consciência, do reconhecimento de si como alguém que simultaneamente odeia e participa da situação odiada. A cisão é sentida como um fator da realidade brasileira: é esta que afasta a identidade autocriada do poeta da identidade que lhe é imposta de fora, dispersando o projeto de uma vida conscientemente criada e reafirmando uma vida cegamente vivida sob um impulso irracional. Esse movimento poético-reflexivo pode ser lido nos versos da "Meditação":

\footnotetext{
${ }^{370}$ Para se ter em mente o peso desse problema, podemos notar que algo dessa mesma ordem ocorre, segundo Rodrigo Naves, em um momento decisivo da obra de Volpi. Analisando o quadro Bandeirinhas "primavera", de meados da década de 1960, o crítico escreve: "Por fim, se estabelece um presente na obra de Volpi. Ele se mostra de relance e sua intensidade tem a marca da extinção. O presente carece de organicidade e apenas desmonta em manifestações contingentes, fadadas a uma vida breve" (NAVES, Rodrigo. Anonimato e singularidade em Volpi. A forma difícil. Ensaios sobre arte brasileira. São Paulo: Editora Ática, 2001. p. 194).

${ }^{371}$ Ver Capítulo I desta tese.
} 
E eu mesmo me reconstituí árduo na dor

Por minhas mãos, por minhas desvividas mãos, por

Estas minhas próprias mãos que me traem,

Me desgastaram e me dispersaram por todos os descaminhos,

Fazendo de mim uma trama onde a aranha insaciada

Se perdeu em cisco e polem, cadáveres e verdade e ilusões.

Mas porém, rio, meu rio, de cujas águas eu nasci,

Eu nem tenho direito mais de ser melancólico e frágil,

Nem de me estrelar nas volúpias inúteis da lágrima!

Eu me reverto às tuas águas espessas de infâmias,

Oliosas, eu, voluntariamente, sofregamente, sujado

De infâmias, egoísmos e traições. E as minhas vozes,

Perdidas do seu tenor, rosnam pesadas e oliosas,

Varando terra a dentro no espanto dos mil futuros

(versos 40-53)

Esses versos descrevem o fracasso do poeta que quis se "purificar no barro dos sofrimentos dos homens" (v. 39). Há um percurso não linear de autodescrição desse trecho. O poeta nasceu das águas do rio, ele foi gerado nas águas do contágio, nas águas da história brasileira. No entanto, passou por um processo de autocriação reflexiva, a se reconstituir na dor dos homens. Dessa reconstituição, cujo sinal na obra de Mário é o Amazonas, o rio da história brasileira a ser construída, nasce o poeta do Modernismo, principalmente o do Modernismo nacionalista, que deseja sacrificar-se pela renovação da poesia, da literatura, da cultura e da história brasileiras. Contudo, nesse sacrifício, o poeta exercia duas funções: a vítima sacrificial e o sacrificador. Ele era ao mesmo tempo vítima e agente da história brasileira por vir. Esse é o ciclo de sua poesia da década de 1920. De 1930 em diante, o poeta começa a se ver destituído da condição de agente do sacrifício e passa a se perceber como parte de uma história a que ele não tem controle nem acesso. Desse sentimento, surge o conflito de consciência que explode em "O Carro da Miséria", e o "algoz de si mesmo" ainda é uma última tentativa de o poeta direcionar o próprio sacrifício, agora em negativo, passando do dionisismo alegre de 1920 ao dionisismo expiatório de 1930-1940. Essa autorrejeição expiatória ecoa forte ainda nos versos da "Meditação", em que o poema se nega o privilégio da lamentação e da autocondescendência. O que muda em "A Meditação sobre o Tietê" é que o poeta 
não é mais o sacrificador, ele não é mais agente, mas somente a vítima sacrificial. Porém, não a vítima sacrificial do Brasil por vir, mas a vítima sacrificial da modernização conservadora, da renovação que repõe o Brasil de sempre, numa paradoxal conservação de um ritmo destrutivo e cego. A astúcia de Mário nessa grande meditação é transformar seu sacrifício em um rito cuja enunciação pertence à vítima, o que impede o sacrificador de negligenciá-la. A esse rito responde a solenidade do verso livre-versículo do poema, construído com o próprio potencial renovador da matéria brasileira que está sacrificando. Nessa autodescrição não linear, então, o poeta nasce da história brasileira, purifica-se buscando purificá-la, percebe-se como parte da sujeira a ser purificada e se rejeita, até se declarar vencido, definitivamente sujado pelas águas do rio. No entanto, todo esse processo de uma grande derrota é documentado pela pesquisa da matéria e das formas brasileiras, criando uma espécie de recolhimento e compactação da experiência brasileira como um todo, podendo dispô-la e dispor a si mesmo segundo sua potencialidade latente de renovação. Assim, o complexo dionisíaco-sacrificial é uma solução mítica que responde à potencialidade da própria matéria brasileira, cujas desconexões, desajustes e desconcertos - com suas implicações de dominação histórica e de classe - como que clamam por uma redenção, uma maneira de se socorrer no mito para livrar-se de um mundo calamitoso.

\author{
$* * *$ \\ Ôh, doce amiga, é certo que seríamos felizes \\ Na ausência deste calamitoso Brasil!... \\ ("Poemas da Amiga", parte V, versos 20-21)
}




\title{
CONCLUSÃO - ACUMULAÇÃO POÉTICA, POSIÇÃO POLÍTICA E O SENTIDO DO MODERNISMO
}

\author{
Tudo que à noite perdemos \\ se nos confia outra vez. \\ Drummond. "Passagem da Noite"
}

Uma tendência constante da poesia de Mário de Andrade é, como vimos, extrapolar os limites da formalização poética, desejando tornar a poesia algo mais do que apenas poesia. Uma série de sortilégios é utilizada pelo poeta para alcançar esse fim: a dança de palavras, o regressus ad uterum, a filia, a hipnose, a mutilação destrutiva e autodestrutiva, e, mais importante de todos, o sacrifício, que abre o ciclo dionisíaco morte-ressurreição. Esses sortilégios não são temas, assuntos, símbolos, imagens ou qualquer outro elemento de que a poesia é constituída e de que se nutrem suas possibilidades. Antes, eles abalam a própria natureza da poesia lírica, que rompe suas limitações e passa a funcionar como uma verdadeira magia. Não são poucas as ameaças regressivas de uma ruptura tão grande com a secularização da arte e de uma imersão tão profunda no mito. De procedimentos parecidos se alimentaram algumas das piores ideologias, artísticas e não artísticas, do século XX. Por isso, tomado em abstrato, apenas como procedimento e separado de sua fenomenologia, esse movimento da poesia mariodeandradiana se torna obscuro e abstruso, incompreensível ou apenas parcialmente compreensível, aberto a todas as possibilidades de julgamento, laudatório ou condenador, mas sempre incompleto. O que, a meu ver, esclarece esse movimento de junção de poesia e magia é o entendimento da sua causa motivadora e do seu sentido. Com essas duas questões em vista, pode-se entender melhor a sua significação. O que se propôs ao longo deste trabalho, então, foi mais uma tentativa daquele velho exercício crítico de relacionar dialeticamente texto e contexto. O que muda, ou que tentei mudar, foi trazer para essa relação texto-contexto algumas estruturas profundas da história, da sociedade e da literatura brasileira. Dessa perspectiva, um mesmo motivo estrutural profundo, que é acessado por uma reflexão histórico-filosófica, age simultaneamente no ritmo histórico, na organização social e na estruturação formal da obra literária. Age simultaneamente, mas o modo como essa ação é percebida e configurada pode ser muito diverso, e suas possibilidades são infinitas. Assim, a impossibilidade de formação do sujeito - de ser idêntico a si mesmo para poder ser solidário ao outro - é resolvida pelo 
poeta Mário de Andrade com o apelo à magia. Roger Bastide, que elaborou algumas das mais finas observações sobre sua poesia, conclui seu texto sobre Mário com as palavras: “Compreende-se então por que Mário de Andrade é poeta. É que ele foi condenado à poesia. Cercado de ausências, viu-se forçado ao sortilégio e à magia de transformar todas essas obscuras ausências em presenças luminosas". ${ }^{372}$ Diferentemente dos anseios de plenitude do sujeito poético da poesia europeia moderna, que busca dissolver a individuação não emancipada ${ }^{373}$ integrando-se no orfismo mallarmeano ou no vitalismo rimbaudiano (para falar somente em duas vias da moderna poesia europeia), o que o sujeito poético mariodeandradiano deseja é reconhecer-se e, reconhecendo-se, buscar a fraternidade. Desse modo, não se trata em sua poesia dos constrangimentos e superações do sujeito que existe de facto, individuado pela sociedade moderna, mas da inquietude de quem busca ser um sujeito de jure, uma busca de poder exercer as prerrogativas de um sujeito moderno. Essa não individuação do sujeito brasileiro é a sua ausência fundamental, geradora de muitas outras ausências. Ausência que serviu de base, na poesia modernista e fora dela, a muita adesão a mitos de direita, que supriam a ausência com um totem-restaurador: o Integralismo (que não se perca pelo nome), a poesia em Cristo (que era uma "restauração", com o lema "restaurar a poesia em Cristo"), e, no plano social, o Estado forte, supridor de ausências fundamentais, simultaneamente autoritário e paterno. Em Mário, sua magia e seu sortilégio visaram ser uma solução fraterna da ausência, guardando sempre uma posição mais à esquerda, que se acirrava e se tornava explícita no último período de sua obra. A principal formulação "à esquerda" de Mário é o seu dionisismo sacrificial: o seu doar-se plenamente para a liberdade de outrem, ou, em sua versão posterior, a destruição purificadora de todos os pressupostos oprimentes da existência, destruição necessária para um renascimento "libertado" das coisas, dando inflexão materialista ao ciclo morte-ressurreição do dionisismo. Essa versão destruidora da história brasileira tal qual configurada até então, essa necessidade de purificação e libertação da matéria sufocada, esse ódio ao que é oprimente e deprimente vai ter continuidade em uma flor que nasce do ódio, rompe o asfalto e dá a

\footnotetext{
${ }^{372}$ BASTIDE, Roger. Mário de Andrade [1940]. Poetas do Brasil. São Paulo: Edusp/Duas Cidades, 1997. p. 80.

${ }^{373}$ Lembrando que o processo de individuação e subjetivação na história europeia moderna ocorreu de modo contraditório, pois as potencialidades de emancipação do sujeito foram freadas e progressivamente tolhidas em favor da autoconsevação do indivíduo para as finalidades da sociedade industrial. Esse percurso dialético da subjetividade é descrito em ADORNO, Theodor W.; HORKHEIMER, Max. Dialética do esclarecimento. Rio de Janeiro: Jorge Zahar, 1985. Principalmente no Excurso I: Ulisses ou Mito e Esclarecimento.
} 
poucos uma esperança mínima. Estou falando da recuperação dos dilemas da poesia mariodeandradiana por Drummond em A rosa do povo. Evidente na década de 1920, o laço entre Carlos Drummond de Andrade e Mário de Andrade nos quinze anos posteriores é menos observado pela crítica de poesia brasileira. ${ }^{374}$ Parte do problema se deve à publicação recente das cartas de Drummond a Mário, ocorrida somente em $2002,{ }^{375}$ parte se deve à constituição formalista e universalizante (mais generalizante do que universalizante, a bem dizer) da crítica de poesia brasileira. Na formação do nosso cânone de poesia moderna, esquematicamente falando, Drummond figura como central, capaz de abarcar os grandes dilemas do homem moderno, enquanto a poesia de Mário de Andrade (e Mário costuma ser lembrado somente como autor de Paulicéia desvairada) faria parte da história documental da modernidade brasileira, sem maiores ressonâncias. As ausências brasileiras, sentidas também pela crítica de poesia, são supridas por esta por um formalismo de aspiração universalizante, quase sempre à reboque de alguma teoria europeia ou norte-americana, que lhe daria lastro de atualidade mundial e relevância local. ${ }^{376} \mathrm{O}$ que se perde nessa história da crítica da poesia brasileira em litígio com a própria poesia brasileira é a ruptura dos laços internos, por vezes muito frágeis, que a constituem. Contrariamente a isso, podemos ver que a relação de Drummond e Mário, nos últimos anos de vida deste, e principalmente em 1944, retoma o vigor da década de 1920, mas agora em outro plano. ${ }^{377}$ Do nível da estética modernista passou-se à reflexão estético-política sobre a poesia. Mas, ainda aqui, Drummond se vê espelhado e, de certa forma, amparado por Mário: "Eu me sinto justificado nas suas obras completas; me sinto também explicado e realizado. Acho que você foi grande por si mesmo, pela força própria e pelo suor do seu trabalho, mas um

\footnotetext{
374 Tampouco a relação entre a poesia dos dois é muito estudada nesse momento inicial de nosso Modernismo, um dos raros estudos é "Drummond e Mário de Andrade", em GLEDSON, John. Influências e impasses. Drummond e alguns contemporâneos. São Paulo: Companhia das Letras, 2003. Proponho nesse argumento uma descrição panorâmica de uma questão central da constituição da nossa crítica, panorama em que não figuram, logicamente, as gratas exceções que formam o pequeno grupo de nossas melhores obras de crítica literária.

${ }^{375}$ SANTIAGO, Silviano (Org.). Carlos \& Mário. Correspondência de Carlos Drummond de Andrade e Mário de Andrade. Rio de Janeiro: Bem-Te-Vi, 2002.

${ }^{376}$ Sobre isso, SCHWARZ, Roberto. Nacional por Subtração. Que horas são? São Paulo: Companhia das Letras, 2006.

${ }^{377}$ Esse diálogo, pela evidência do poema "Mário de Andrade desce aos Infernos", de A rosa do povo, é comentado panoramicamente por todos os que se debruçam pelo conjunto do livro de Drummond de 1945. A pertinência desse diálogo, contudo, é raramente notada. Ela está mais presente, entretanto, em SIMON, Iumna Maria. Drummond: uma poética do risco. São Paulo: Ática, 1978. p. 109-114. Também Vagner Camilo retoma esse diálogo, pensando nas posturas de Drummond no pós-guerra, ver CAMILO, Vagner. Drummond: da rosa do povo à rosa das trevas. São Paulo: Ateliê Editorial, 2001. p. 58-62.
} 
pouco dessa grandeza se espalha por todos nós e nos engrandece também". 378 E especificando melhor a admiração por Mário naquele exato momento da vida intelectual e política brasileira, Drummond conclui: “Ah! Mário, cada vez admiro mais a sua inconformidade e o seu nojo feroz dessa felicidade barata... A sua conferência sobre o modernismo e o prefácio ao Otávio de Freitas Lima são duas metralhadoras". ${ }^{379}$ Essas são palavras sobre o significado histórico e ideológico da obra de Mário de Andrade dentro do Movimento Modernista como um todo. Sobre a relação propriamente poética que Drummond estabelece com Mário a essa altura, há carta de 18 de julho de 1944: "sua poesia é para mim um ponto de partida para novas procuras e novos achados", e conclui:

Peço-lhe ardentemente que continue a mandar-me os versos que for fazendo, pois se me interessa muitíssimo tudo que você faz, os versos mais do que qualquer coisa, pela solidão da poesia entre nós, pela necessidade que eu sinto de ver uma grande força como você resolvendo os problemas de nós todos. Não se esqueça deste seu amigo também insatisfeito e perplexo (já não são mais aqueles sentimentos infelizes de vinte anos atrás, liquidados por sua crítica arrasadora e por um largo trabalho de análise da minha parte) são outros, o que você pode bem avaliar; chego a me convencer que eles me honram um pouco, pelo que têm de empenho. ${ }^{380}$

Mário exerce, então, uma dupla influência em Drummond: como um poeta que se coloca problemas estéticos e busca resolvê-los, ou seja, como um poeta-técnico, e como um amigo-formador, capaz de agir sobre a própria constituição humana do amigo, ambos capazes de se autoavaliar e, ao mesmo tempo, compartilhar uma humanidade comum e gratuita. Desse modo, é letra e espírito de Drummond que se sentem vinculados a Mário de Andrade, e que em dado momento visam a uma sintonia poética em que se harmonizam o empenho de Drummond e o legado poético e humano de Mário.

\footnotetext{
${ }^{378}$ Carta de 9 de dezembro de 1944. SANTIAGO, Silviano (Org.). Carlos \& Mário. Correspondência de Carlos Drummond de Andrade e Mário de Andrade, cit., p. 536.

${ }^{379}$ SANTIAGO, Silviano (Org.). Carlos \& Mário. Correspondência de Carlos Drummond de Andrade e Mário de Andrade, cit., p. 537. Os textos citados por Drummond são "O Movimento Modernista" e "Segundo Momento Pernambucano", ambos publicados em ANDRADE, Mário de. Aspectos da literatura brasileira. Belo Horizonte: Itatiaia, 2002. Sobre esse último texto, Drummond se enganou na escrita do nome do autor do livro prefaciado, que é Otávio de Freitas Júnior. Sobre o significado de "O Movimento Modernista", ver a interpretação dada nesta tese no Capítulo I.

380 SANTIAGO, Silviano (Org.). Carlos \& Mário. Correspondência de Carlos Drummond de Andrade e Mário de Andrade, cit., p. 507-508.
} 
A falta de justa apreciação da poesia e da posição de Mário de Andrade poeta no Movimento Modernista pela crítica literária brasileira é notada pelo próprio Drummond, em carta de 19 de maio de 1942, sobre o aparecimento do livro Poesias (1941) de Mário:

... a emoção que foi para mim a leitura de suas Poesias [1941]. [...] me assombrou a importância da sua poesia, assim reunida em livro único, que mostra bem a sua força lírica, às vezes um pouco esquecida diante da variedade da sua obra de ensaísta. Acho que sua obra poética está guardada para uma aceitação futura integral, tanto mais quanto nela é mínima a porção capaz de obter agrado fácil e imediato. Descobri que você esta só no meio de vários poetas, só pelas suas preocupações especiais, pela sua realização própria, pela complexidade de sua pena poética. Nenhum índice mais impressionante da fragilidade da crítica brasileira de poesia do que o comportamento dela diante de você poeta. Parece que você permanecerá intato e puríssimo para o gosto e a compreensão amadurecida da gente que há de vir... ${ }^{381}$ [grifo meu].

Drummond avalia duplamente a importância de Mário: objetivamente como poeta modernista, por suas preocupações especiais, realização própria e complexidade da pena poética, conforme se depreende desta última citação; subjetivamente como poeta modelo do próprio Drummond, exemplo de humanidade e postura intelectual, e alguém que propõe problemas fundamentais e os resolve à sua maneira, o que é um ponto de partida para novas resoluções. Esta última avaliação de Drummond se pode depreender das citações anteriores. A minha proposta de análise é a de que, entre 1942-1945, o diálogo renovado dos dois poetas faz com que o sentido geral da poesia de Mário seja apreendido e incorporado por Drummond em sua reflexão e composição poética, e cujo resultado é uma estrutura profunda que se apresenta em seu livro de 1945, A rosa do povo. Essa estrutura profunda de que falei é o sentido de uma destruição purificadora, que é um modo específico de Drummond apreender o ciclo dionisíaco morteressurreição que orienta a obra de Mário. Aqui é preciso distinguir entre a noção de influência e a noção de problemas herdados e compartilhados. Se, de certa forma, Mário pode influenciar Drummond no uso de algumas técnicas e imagens ou no uso do poema longo, por exemplo, essas “influências" são algo muito pouco relevante diante da reflexão autônoma de dois grandes poetas sobre problemas que interessam a ambos e

${ }^{381}$ SANTIAGO, Silviano (Org.). Carlos \& Mário. Correspondência de Carlos Drummond de Andrade e Mário de Andrade, cit., p. 474-475. Sobre a importância de Mário na formação de Drummond há também a crônica Suas Cartas [1944], recolhida em ANDRADE, Carlos Drummond de. Confissões de Minas [1944]. Prosa seleta. Rio de Janeiro: Nova Aguilar, 2002. 
cujas realizações trazem de modo pouco explícito, mas com importância decisiva, a marca do diálogo. Drummond incorpora o sentido da poesia mariodeandradiana porque passa a compartilhar desse sentido por meio de uma avaliação autônoma e reflexiva de si mesmo, da poesia de Mário, da história brasileira e de suas potencialidades de significação. A conotação subalterna do par influenciadorinfluenciado é aqui totalmente eliminada. Drummond, por questões de idade e de posição dentro do Modernismo, herda os problemas e soluções legados por Mário, o que não só aumenta a importância do poeta paulista em relação ao mineiro como, pelo reverso dialético, aumenta a importância de Drummond em relação à obra de Mário, que passa a avaliá-la rigorosamente na medida mesma em que a toma para si. Desfeita uma possível confusão entre influência e diálogo crítico, é necessário expor de que maneira o sentido da poesia de Mário converge para A rosa do povo. O quadro geral desse sentido poético pode ser apreendido no fato de que, no livro de Drummond de 1945, uma humanidade verdadeira só é possível se ela surgir de uma destruição purificadora: as palavras precisam extinguir suas afinidades sedimentadas (como "sono" e "outono", de "Consideração do Poema") ou sua referencialidade elementar em "Procura da Poesia"; a flor de "A Flor e a Náusea" nasce não somente do asfalto mas também do ódio e do ímpeto incendiário do sujeito lírico ("Pôr fogo em tudo, inclusive em mim", "meu ódio é o melhor de mim"), e mesmo a famosa orquídea antieuclidiana de "Áporo" só se forma, desatando o seu labirinto, após um movimento descendente de cavar a terra e adquirir ciência do "enlace de noite, raiz e minério" do "país bloqueado". Em "Nosso Tempo", a solução quanto a um mundo de "absoluta corrupção"382 é assim expressa pelo poeta: "com suas palavras, intuições, símbolos e outras armas/promete ajudarla destruí-lo" [grifo meu]; um mundo parecido, feito de temor e violência, em "Morte do Leiteiro", é redimido pela morte de um inocente e o reconhecimento de culpa do assassino, em que a aurora surge da mistura do leite e do sangue; e, ainda na circunscrição temática da violência do tempo presente, o poeta deposita suas esperanças, no cenário da Segunda Guerra Mundial, na "cidade destruída” Stalingrado, como dizem os versos: "pois que entre as ruínas/outros homens surgem, a face negra de pó e de pólvora,/e o hálito selvagem da liberdade". No plano da consciência subjetiva, após a imersão noturna da consciência em "Passagem da Noite", em que o processo noite-amanhecer do tempo é análogo ao processo expiação-ressurgimento da vida, há

\footnotetext{
${ }^{382}$ Expressão de John Gledson (Poesia e poética de Carlos Drummond de Andrade. São Paulo: Duas Cidades, 1981. p. 167).
} 
em "Uma hora em mais outra" a definição mesma do procedimento nos versos finais: "pois a hora mais bela/surge da mais triste"; da consciência subjetiva à consciência da alteridade, o poeta figura o surgimento do mundo dos homens iguais - ou equânimes pela sua própria mutilação e morte nas mãos do "irmão vingador" em "Movimento da Espada"; e passando da consciência da alteridade para a consciência do poeta como indivíduo, sujeito participante do espaço público, é ainda da eliminação do indivíduo público historicamente determinado, do regresso a uma irredutível solidão, que surge a possibilidade do conhecimento do outro e da fraternidade, como escreve o poeta em "América". Na esfera amorosa, a paixão alimentada pelo mundo mercantil em "O Mito" só é desfeita quando o poeta desarma o "mito" de fulana "de burguês sorriso/e de tão burro esplendor" e se aventura na composição - hipotética - de um amor que também seja fraternidade. Já no plano da família, especificamente da figura do pai, é ainda na noite, na noite do tempo e da consciência, o lugar por excelência da expiação em A rosa do povo, ${ }^{383}$ que é possível o entendimento por meio do diálogo com o pai: “Guardavas talvez o amor/em tripla cerca de espinhos//Já não precisas guardá-lo./No escuro em que fazes anos,/no escuro,/é permitido sorrir". Ainda o tema da morte passa pelo crivo expiação-ressurgimento, pois a morte do poeta em "Os Últimos Dias" pode ser encarada de modo mais sereno a partir da conclusão: "vida aos outros legada", e da morte de outro poeta, Mário de Andrade, surge em "Mário de Andrade desce aos Infernos", a "rosa do povo", título do livro de poemas de Drummond, que o poeta Mário de Andrade "nas trevas, anunciou" [grifo meu]. Todo esse complexo temático - linguagem, tempo presente, consciência subjetiva, consciência social, amor, família e morte - é exposto nos poemas citados como ciclo dionisíaco completo: morte-ressurreição ou expiaçãoressurgimento. Em outro grupo de poemas, esse ciclo dionisíaco não se completa, ou porque é travado e padece as consequências do bloqueio - o fardo do país bloqueado -, ou porque as suas possibilidades de realização são muito frágeis, e Drummond configura uma espécie de dionisismo fragilizado ou dionisismo em potência. Poemas que desenvolvem uma condição em que há um bloqueio da possibilidade do ciclo dionisíaco são: “O Medo", que tematiza um dos próprios elementos principais que travam o aspecto superador do dionisismo; "Vida Menor", que idealiza uma vida

\footnotetext{
383 Chaplin, por exemplo, em "Canto ao Homem do Povo Charlie Chaplin" traz a esperança porque, vestido de negro ("A noite banha a sua roupa"), ele traz a face branca ("E a lua pousa/em teu rosto"), e da radicalização desse contraste da noite mais densa e do branco mais claro surgem os olhos e a boca ("sorrir, aurora, para todos").
} 
involutiva, reduzida ao mínimo essencial; 384 "Resíduo", cuja senda poética é a vida feita do contágio de elementos heterogêneos e da manutenção do que deveria ser superado: “Oh, abre os vidros de loção/e abafa/o insuportável cheiro da memória"; a desolação de "Consolo na Praia", em que a ideia de insolubilidade dos problemas se resolve em suicídio imaginado, nudez e acalanto; a prefiguração do "enterrado vivo" em "Indicações"; e a persistência do passado, do rio da história brasileira sedimentada em “Onde há pouco falávamos", na imagem de um antigo piano. A latência do dionisismo se apresenta em "Anoitecer", em que o poeta imerge na hora mais triste sem vislumbrar a hora mais bela, mas configurando as condições de seu surgimento; em "Rola Mundo", em que o aspecto destrutivo sobrepuja qualquer outro, sem que da destruição surja o elemento libertador e construtivo; em "Economia dos Mares Terrestres", cuja comunicação subterrânea se mantém latente, mas não se completa; em "Anúncio da Rosa", cujo sentido é a impossibilidade de transação comercial da rosa, que tem em potência o surgimento de uma rosa não vendável, mas que o poema não desenvolve; em "Caso do Vestido", que narra da perspectiva do materno as consequências desastrosas das veleidades sexuais do patriarca, abrindo outra perspectiva sobre os modos de dominação e suas consequências no Brasil; ${ }^{385}$ e, por fim, em “O Elefante”, um de seus exemplos mais belos, em que a dificuldade de agir solidariamente e a exposição da fragilidade das possibilidades do $e u$ já contêm em latência a necessidade do mito (do mito dionisíaco) para criar o mundo da solidariedade efetiva. A enumeração de poemas das últimas três páginas, apesar de longa, não pretende ser exaustiva. Sua intenção é apenas o mapeamento das linhas gerais de uma dialética interna à obra. Não há espaço para estudar detidamente as questões fundamentais que se desdobram dessa descrição de linhas gerais que se espalham pelos poemas, quais sejam, a presença simultânea no livro de Drummond de 1945 do ciclo dionisíaco completo e do ciclo incompleto, bem como suas consequências. Porém, cabe aqui a tentativa de acompanhar como Drummond concebe o anunciador da "rosa do povo", concepção esta presente no próprio livro, em "Mário de Andrade desce aos Infernos", e que pode servir de

\footnotetext{
${ }^{384}$ Lafetá notou a proximidade de sentimento interior entre "Vida Menor", de Drummond, e "Rito do Irmão Pequeno", de Mário de Andrade (LAFETÁ, João Luiz. Figuração da intimidade. São Paulo: Martins Fontes, 1986. p. 206-207).

${ }^{385}$ Note-se a proximidade da adesão à perspectiva do materno em "Caso do Vestido" e da fraternidade antipatriarcal de Mário, que tentei estudar nas linhas finais do Capítulo IV desta tese. Uma perspectiva do masculino sobre a mesma questão de "Caso do Vestido" pode ser lida em "A Partida", de Vinícius de Moraes, publicado em Poemas, sonetos e baladas (1946).
} 
introdução a um estudo mais detalhado, cuja realização dependerá da confirmação da relevância real da perspectiva e das vicissitudes do porvir.

\section{Presença de Mário de Andrade}

A princípio, o sentimento da perda do amigo em "Mário de Andrade desce aos Infernos", poema longo dividido em quatro partes, pouco ou nada deixa entrever da absorção por Drummond de um projeto poético ou do sentido de uma obra poética como a de Mário de Andrade. O título e a primeira estrofe ecoam o mito de Orfeu, cultor de Dionísio, que tocava sua lira de tal modo que maravilhava as feras e a natureza como um todo, e que desceu ao Hades para trazer de volta sua amada morta, Eurídice. Mas, diferentemente do mito, aqui é o próprio poeta que morre. Assim, o significado da primeira parte do poema é eminentemente de homenagem, de tornar perene o amigo, em uma obra mais perfeita do que a natureza:

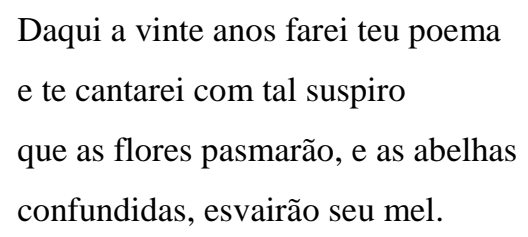

Parte I (versos 1-4)

São versos antes amorosos do que analíticos. O poema ideal de Drummond é pautado por aquele amor-amizade que era o mais alto ideal humano de Mário: a filia. ${ }^{386} \mathrm{~A}$ reunião de forças necessárias dispõe o poema como projeto futuro, nesses verbos no futuro do indicativo que marcam cada verso. A estrofe em versos livres é organizada fundamentalmente pelos verbos no futuro e pelas imagens de uma natureza sobrepujada. O suspiro mais que humano, realizado no poema, desorientará a natureza, porque seu princípio ordenador será superior, de uma beleza mais rara do que a das flores, e uma doçura mais sedutora que a do mel. Das hipérboles dessas imagens que descrevem a ação do poema futuro pode-se depreender certa analogia entre a natureza do poema e a natureza de seu inspirador. O poema sobrepuja a natureza porque Mário de Andrade significa um princípio ordenador mais elevado. O poeta paulista não somente pode encantar e reordenar a natureza (conforme veremos adiante) como é portador do ideal

${ }^{386}$ Ver Capítulo III desta tese. 
mais elevado: a formação humana levada a cabo com rigor e carinho, em uma alquimia rara de Bildung goethiana ${ }^{387}$ e filia. Contudo, as urgências do momento, sejam as demandas participativas da época, seja a necessidade de externar a dor da perda, fazem com que o canto realize-se no agora, carregando as marcas da sua imediatidade:

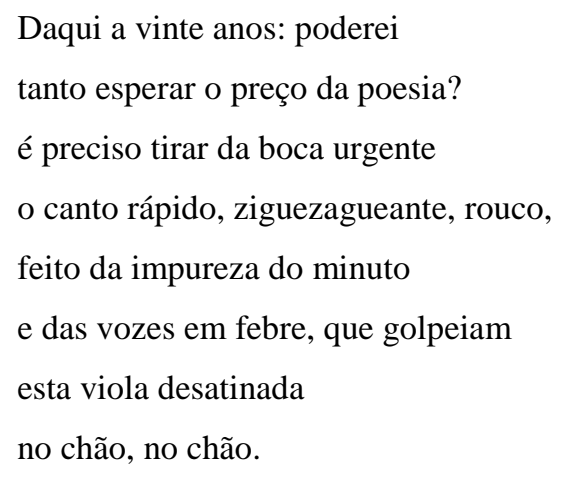

Parte I (versos 5-12)

Se não é o tempo ainda da filia, é certamente o tempo de outro traço mariodeandradiano essencial: a sinceridade. A "impureza do minuto" ordena a expressão, de um verso livre rápido, que assume quase uma forma de delírio da dor, composto de rapidez, movimentos desorientados ("ziguezagueantes"), vozes em febre, queda, golpes na viola "no chão" - sintagma repetido três vezes, duas nesse verso e uma no início da parte II. Essa primeira parte é composta de um dramatismo intenso; porém, o que deve chamar a nossa atenção são os traços mariodeandradianos que a compõem: ideal elevado da filia, demanda de sinceridade total, transe (delírio da dor) - uma extroversão sem censura do movimento subjetivo, incaracterístico da subjetividade lírica tímida de Drummond. Inicialmente, então, não se trata de absorção do projeto poético ou do sentido da obra poética de Mário, mas de uma incorporação no próprio poema de características profundas do homem e de sua poesia.

Algo da lucidez característica de Drummond retorna na natureza reflexiva e descritiva da parte II:

\footnotetext{
387 “Eis o conceito goethiano de 'Bildung', de 'formação': a transformação do caos de experiências e conhecimentos em uma estrutura orgânica” (CARPEAUX, Otto Maria. História da literatura ocidental. Rio de Janeiro: Edições O Cruzeiro, 1961. v. IV, p. 1.619).
} 
No chão me deito à maneira dos desesperados.

Estou rigorosamente noturno, estou vazio, esqueço que sou um poeta, que não estou sozinho, preciso aceitar e compor, minhas medidas partiram-se, mas preciso, preciso, preciso.

Rastejando, entre cacos, me aproximo. não quero, mas preciso tocar pele de homem, avaliar o frio, ver a cor, ver o silêncio, conhecer um novo amigo e nele me derramar.

Porque é outro amigo. A explosiva descoberta ainda me atordoa. Estou cego e vejo. Arranco os olhos e vejo. Furo as paredes e vejo. Através do mar sanguíneo vejo. Minucioso, implacável, sereno, pulverizado, é outro amigo. São outros dentes. Outro sorriso. Outra palavra, que goteja.

A lucidez desses versos não é consequência de uma diminuição da dor da perda, que não há, mas da observação que Drummond faz de si mesmo, do processo analítico interno ao próprio dilaceramento subjetivo. $\mathrm{O}$ verso livre se torna mais longo e mais pausado, sua natureza é mais descritiva, como se o poeta buscasse mapear seu próprio sofrimento. O primeiro verso é modelar nesse sentido: "No chão me deito à maneira dos desesperados". Seu significado é extremamente doloroso, mas sua dicção é mais sóbria. Como se o poeta ardesse em chama fria, ele consegue perscrutar-se, e tenta fazer seu trabalho de luto, de reconhecimento da perda e necessidade de comunicar-se. Na segunda estrofe, essa parte II faz uma espécie de dionisismo em miniatura, pois o poeta retoma a lucidez depois de fazer a constatação mais terrível: "Estou rigorosamente noturno, estou vazio". O que pode compor e comunicar quem está rigorosamente noturno e vazio? Ainda aqui, em um tipo de "realismo psicológico", 388 Drummond vai compor a documentação de seu próprio processo de retomada de consciência, de consciência da própria existência e condição de poeta, da necessidade de comunicação. Todo o restante da segunda estrofe é um documento psicológico do trabalho de luto, de sentimento de perda, perda da própria capacidade poética ("minhas medidas partiram-

\footnotetext{
${ }^{388}$ Ver Capítulo II desta tese.
} 
se”) e do propósito de seguir adiante ("mas preciso, preciso, preciso"). Prosseguindo o "realismo psicológico", algo da natureza de Mário de Andrade continua sendo apresentada na terceira estrofe. A necessidade de um novo amigo, alcançado, hipoteticamente, por meio de um percurso dilacerante ("rastejando, entre cacos"), revela a importância do amigo perdido. Ele era $o$ amigo, incomparável e superior, o amigo ideal. A quarta estofe retoma o frenesi da parte I, com sua enumeração de imagens dilacerantes. Como em novo transe, o novo amigo é alcançado por um processo de despedaçamento e recomposição, em outro transporte dionisíaco. O trabalho de luto, de aceitação da perda e aceitação de um novo amigo, ainda é feito, nessa parte II, pela incorporação de procedimentos mariodeandradianos: o realismo psicológico e o ciclo despedaçamento-recomposição do dionisismo. Mas aqui a dicção drummondiana, lúcida e analítica, filtra e absorve esses procedimentos, com exceção do clímax da última estrofe. O amigo perdido reaparece agora, na parte III, recomposto com lucidez e calma, portador de um sentido humano, reconhecido por Drummond em sua existência biográfica e, por contiguidade, em sua prática poética:

\footnotetext{
O meu amigo era tão

de tal modo extraordinário,

cabia numa só carta,

esperava-me na esquina,

e já um poste depois

ia descendo o Amazonas,

tinha coletes de música,

entre cantares de amigo

pairava na renda fina

dos Sete Saltos,

na serrania mineira,

no mangue, no seringal,

nos mais diversos brasis,

e para além dos brasis,

nas regiões inventadas,

países a que aspiramos,

fantásticos,

mas certos, inelutáveis,

terra de João invencível,

a rosa do povo aberta...
} 
O metro se uniformiza na redondilha maior, verso popular por excelência, com algumas quebras de metro por questões de ênfase, como o segundo verso aumentado (a não ser que se faça a redução fonética "extrordinário"), a redondilha quebrada "dos Sete Saltos" e o verso "fantásticos". A escolha do metro certamente evoca o projeto de Mário de Andrade de imersão na pesquisa da cultura popular, da música popular e do folclore. Possui também o ritmo da redondilha uma naturalidade maior para o ouvido, o que talvez tenha a intenção de reverberar a musicalidade do amigo, seus "coletes de música”. O que habita o ritmo fluente da redondilha são características de Mário, características que logo nos dois versos iniciais já se apresentam como prodígios: "O meu amigo era tão/de tal modo extraordinário". "Extraordinário" em si já veicula um conteúdo de algo a mais: extra-ordinário. Esse "algo a mais" tem um intensificador inicial "tão", que já monta uma hipérbole: “tão extraordinário". Mas Drummond, para não deixar dúvida sobre os prodígios do amigo, agrega mais um intensificador: "tão de tal modo extraordinário", transformando a redundância gramatical em caracterização de um tour de force. ${ }^{389}$ As propriedades desse tour de force, dessa capacidade de prodígios, compõem a enumeração dos versos seguintes até o fim dessa parte. Mais importante do que a soma das características é o padrão de movimento que elas descrevem. Entre o verso 3 "cabia numa só carta" e o verso 13 "nos mais diversos brasis", o que Drummond descreve é o movimento da subjetividade desdobrada. ${ }^{390} \mathrm{O}$ amigo presente na correspondência, o visitante de Belo Horizonte, o viajante pelo Brasil, o pesquisador de música e poeta musical são características que compõem uma capacidade de movimento, um poder de mobilidade que se afigura sobre-humano, por isso as imagens ganham tonalidades surrealistas como os "coletes de música" e o pairar "na renda fina/dos Sete Saltos". ${ }^{391}$ Os elementos do projeto poético de Mário estão igualmente descritos: a pedagogia modernista, a subjetividade desdobrada, a música, as viagens pelo Brasil. O leitor provavelmente está sentindo falta da dança (a não ser pela sutil evocação do nome "Sete Saltos"), mas é justamente ela que, não enunciada nos versos, os está presidindo de modo mais profundo. O movimento dançante da subjetividade

\footnotetext{
${ }^{389}$ Ver Capítulo II desta tese.

${ }^{390}$ Ver Capítulo II desta tese.

391 "Sete Saltos" provavelmente se refere ao rio Sete Saltos, localizado no planalto paranaense. Essa imagem certamente evoca o trecho final de "Noturno de Belo Horizonte": "Ar arejado batido nas pedras dos morros,/Varado através da água trançada das cachoeiras" (versos 403-404), que Drummond elogia em carta de 30 de dezembro de 1924: "Encontro, por exemplo, no fim [do poema], uma 'água trançada das cachoeiras' que tem vida própria" (SANTIAGO, Silviano (Org.). Carlos \& Mário. Correspondência de Carlos Drummond de Andrade e Mário de Andrade, cit., p. 80). Sobre o diálogo Mário-Drummond a respeito de "Noturno de Belo Horizonte", ver Capítulo IV desta tese.
} 
mariodeandradiana entre os elementos estáveis de sua obra poética enunciados nos versos de Drummond desvenda-lhes o seu sentido mais profundo: não a adequação da subjetividade ao Brasil real, tal qual está constituído historicamente, mas a transposição de seus elementos criteriosamente escolhidos para outro plano: "nos mais diversos brasis,/e para além dos brasis,/nas regiões inventadas,/países a que aspiramos,/fantásticos”. A dança de Mário de Andrade, nos versos dessa parte III, faz o transporte dionisíaco dos brasis observados aos brasis inventados, do Brasil real ao Brasil possível. O próprio movimento de descobrimento das características do Brasil e da sua assunção em um país novo, inventado, descreve o percurso do dionisismo e seu ciclo morte-ressurreição. Nenhum dos pontos em que a subjetividade passa e se reconhece (esquina, Amazonas, Sete Saltos, serrania mineira, mangue, seringal) se perde, porque eles vão ser recompostos no país inventado a que se aspira. O elemento imaginativo: "regiões inventadas" e o elemento participativo "países a que aspiramos" são unidos ${ }^{392}$ pelo sentido prodigioso do dionisismo, e seu ciclo morte-ressurreição, ou expiação-ressurgimento. Por isso, esses países não são apenas "fantásticos", são também "certos, inelutáveis/terra de João invencível”. "João" é inegavelmente uma referência ao elemento popular. ${ }^{393}$ Assim, o sentido mítico do dionisismo não se encerra no prodígio do mito, ele se mistura com um projeto histórico-social, com o ciclo morteressurreição, que é uma analogia da liquidação do Brasil classista e surgimento de um Brasil igualitário, país descrito por Drummond no poema "Cidade Prevista": "território de homens livres/que será nosso país/e será o país de todos". ${ }^{394} \mathrm{O}$ sentido poético e histórico-social do dionisismo, elaborado por Mário e recuperado por Drummond, é um alinhamento da poesia modernista à esquerda, trabalhando poeticamente pela destruição do mundo capitalista, principalmente em sua versão brasileira, e recomposição do mundo com os seus elementos redimidos, reconstruídos no ritmo de

\footnotetext{
${ }^{392}$ A união de imaginação e ação como plataforma da poesia moderna já se encontra, pela via da ironia crítica, em Baudelaire, nos versos de "Le Reniement de Saint Pierre': “- Certes, je sortirai, quant à moi, satisfait/D'un monde où l'action n'est pas la soeur du rêve".

${ }^{393}$ Parente do "Homem Zangado, o herói de coração múltiplo,/O justiçador moreno, o esmurrador com mil punhos [...] Ele tem uma estrela de verdade bem na testa/Ele tem um corisco no sapato/E um coração humano no lugar do coração", herói revolucionário da obra de Mário O Café, de que Drummond provavelmente não tinha conhecimento (Os versos citados estão em ANDRADE, Mário de. Poesias completas. Edição crítica de Diléa Zanotto Manfio. Belo Horizonte: Itatiaia; São Paulo: Edusp, 1987. p. 442).

${ }^{394}$ Aliás, a composição de "Cidade Prevista" é das que mais explícita e significativamente dialoga com a obra de Mário. Dos versos citados, é interessante notar o que vem antes, quando Drummond exorta outros poetas a recolherem suas palavras: "Cantai esse verso puro, que se ouvirá no Amazonas,/na choça do sertanejo/e no subúrbio carioca,/no mato, na vila $\mathrm{X}$, no colégio, na oficina,/território de homens livres/que será nosso país/e será pátria de todos" (versos 15-23).
} 
uma humanidade livre, e adequados a ela ${ }^{395}$ Desse modo, o diálogo poético de Mário e Drummond gerou uma "acumulação poética" de temas, formas, procedimentos, mas igualmente de reflexão e entendimento poético do mundo - do mundo brasileiro especificamente, mas não só -, e essa acumulação de formas e reflexões implicava a consecução de uma humanidade livre - sobretudo de um Brasil libertado, mas não só -, bem como alinhava a poesia modernista à esquerda do processo histórico. Essas posições, por sua vez, davam um sentido estético e político ao Modernismo: a necessidade de destruição do Brasil real para a construção do Brasil libertado, "terra de João invencível". Entendo que é esse percurso que aflora no último verso da parte III: "a rosa do povo aberta...”. O símbolo exposto nesse verso é um símbolo poético de luta social, não há dúvida, mas, igualmente, há um significado mais interno à história da poesia modernista, em que "a rosa do povo aberta" é a obra poética de Mário de Andrade germinando o livro de Drummond de 1945, A rosa do povo. O dionisismo que rege como estrutura profunda a obra poética de Mário de Andrade se projeta em outro plano e reaparece na história da poesia modernista, em que a obra de Mário de Andrade morre e renasce em A rosa do povo.

Assim, a parte III faz a absorção completa do projeto poético e do sentido da obra poética de Mário. Já a parte IV desenvolve mais extensamente a qualidade e a natureza desse projeto poético e do sentido dessa obra poética que foram absorvidos. Essa última parte é a mais longa do poema. Nela, a importância, a posição, o valor e os resultados da poesia e da figura de Mário de Andrade são pesados e avaliados por um sujeito lírico que já retornou a si mesmo e apaziguou, pelo ciclo dionisíaco interno ao poema, a perda do amigo. A inquirição inicial dessa parte já repõe a lucidez drummondiana e parte de seu ceticismo:

\footnotetext{
A rosa do povo despetala-se,

ou ainda conserva o pudor da alva?

É um anúncio, um chamado, uma esperança embora frágil, pranto infantil no berço?

Talvez um ai de seresta, quem sabe.

Mas há um ouvido mais fino que escuta, um peito de artista que incha,
}

\footnotetext{
${ }^{395}$ Esse o sentido presente em "Carta a Stalingrado": "Os telegramas cantam um mundo novo/que nós, na escuridão, ignorávamos./Fomos encontrá-lo em ti, cidade destruída,/na paz de tuas ruas mortas mas não conformadas,/no teu arquejo de vida mais forte que o estouro das bombas,/na tua fria vontade de resistir" (versos 11-16), complementado por esses versos iniciais de "Telegrama de Moscou": "Pedra por pedra reconstruiremos a cidade./Casa e mais casa se cobrirá o chão./Rua e mais rua o trânsito ressurgirá" (versos 1-3).
} 
e uma rosa se abre, um segredo comunica-se, o poeta anunciou,

o poeta, nas trevas, anunciou.

Parte IV (versos 1-7)

O poema retoma nessa parte o verso livre fluente de "Nosso Tempo", composto do ritmo livre da subjetividade que observa o mundo e a si mesma, dispondo de ritmos curtos, médios, largos e muito largos. Nessa rítmica, a dor dilacerante está de certa forma mitigada, suspensa na flor que foi anunciada e se abriu. O surgimento dessa rosa, contudo, não se investe das certezas mandatórias de muita poesia engajada anterior e posterior ao livro de Drummond. Ao contrário do posterior engajamento nacionalpopulista e do engajamento marxista ortodoxo, Drummond não confiava que a revolução viria porque adquiriu um tipo de certeza ético-teórica, como se, ao descobrir que a luta de classes existe, que o proletariado é uma classe universal e que a injustiça é a base do sistema capitalista, dessa descoberta nasceria logicamente e sem dificuldade o mesmo mundo justo acessado pela reflexão. Contrário, igualmente, ao curioso engajamento posterior da vanguarda concretista, que confiava que a libertação tautológica da linguagem pela linguagem por si só inaugurava o mundo completamente libertado, como se a liberdade fosse somente um ato de linguagem (embora também o seja). Sem, então, incorrer na confiança desses movimentos da década de 1950 e 1960, Drummond julgava o elemento revolucionário como uma esperança muito frágil, que só poderia ser acessada pela reflexão rigorosa e que só se realizaria por um igualmente frágil equilíbrio entre sentimento, pensamento e ação, que, de sua parte, seria um equilíbrio frágil mas realmente figurado em sua poesia de A rosa do povo. Essa introdução histórica e contextual do problema visa entender por que, encerrada a parte III de "Mário de Andrade desce aos Infernos", quando a rosa do povo se abre, ela inicia a parte IV do poema sendo indagada sobre sua qualidade, seu teor, seu poder de comunicação e permanência. Os dois primeiros versos como que perguntam: a rosa mariodeandradiana está pronta a florescer ou já perdeu sua validade? Não tenho como saber se Drummond chegou a ler o poema "A Meditação sobre o Tietê", em que uma "flor" surge da mais funda dor de Mário na superfície das águas imundas do Tietê. ${ }^{396}$ De

\footnotetext{
${ }^{396}$ Mário morreu em fevereiro de 1945, Drummond publicou A rosa do povo em dezembro do mesmo ano. Nesse meio tempo, o poema esteve na posse de Antonio Candido, que o publicou em 1945 em Lira paulista seguida de O carro da miséria (São Paulo: Livraria Martins, 1945). Consultei Antonio Candido por telefone do dia 22/02/2011 sobre a possibilidade (ou não) de Drummond ter lido o poema. Antonio Candido afirmou não saber nada a respeito. Disse que não havia enviado o poema a Drummond nem o livro depois de publicado, e que não lembrava o mês de publicação. A passagem da "flor" de "A
} 
qualquer forma, a correspondência entre os poetas de 1943-1945 já contém no pensamento de Mário um engajamento agônico, que poderia ser entendido como "um anúncio, um chamado, uma esperança embora frágil, pranto infantil no berço”. A conclusão de Drummond nessa primeira estrofe refaz de certa forma o percurso da parte III: o projeto e o sentido da obra de Mário são captados por "um ouvido mais fino que escuta, um peito de artista que incha" e "um segredo comunica-se". Novamente, há uma transmissão subterrânea entre a obra de Mário e A rosa do povo. A continuidade dessa parte IV de certa forma completa o ciclo dionisíaco apresentado na parte III, e Drummond recompõe o amigo Mário ao entrar em sua casa. A princípio, aparecem os objetos que compõem a casa de Mário, objetos de colecionador, objetos de pesquisador, que se transformam em forças anímicas, caracterizando os prodígios do amigo:

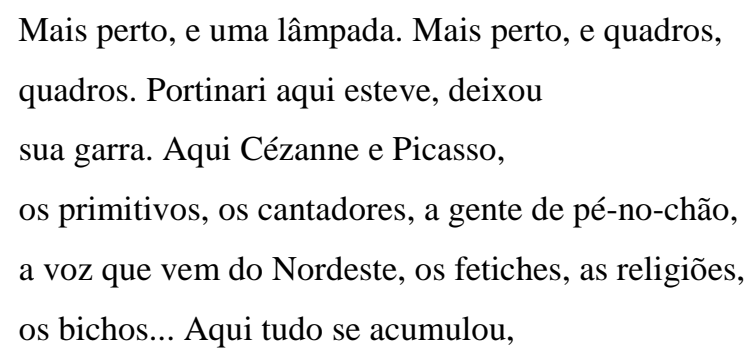

Parte IV (versos 8-13)

Dos objetos e forças anímicas, Drummond passa a sua experiência pessoal dessa casa:

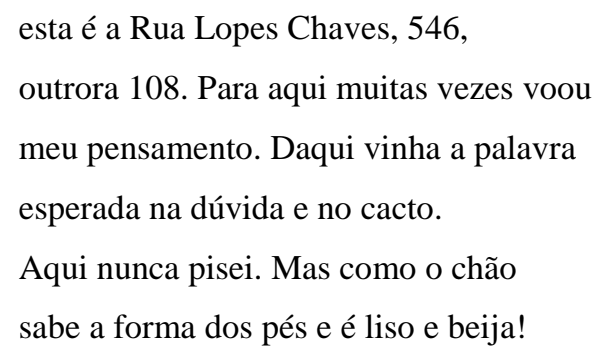

Parte IV (versos 14-19)

O poeta portador de prodígios é também o amigo da palavra certa, quase se diria a palavra mágica, que mais de uma vez orientou a poesia e a vida pessoal do poeta de

\footnotetext{
Mediação sobre o Tietê" ao livro de Drummond é intuída por José Emílio Major Neto quanto ao poema "Áporo" (MAJOR NETO, José Emílio. A Lira Paulistana de Mário de Andrade: a insuficiência fatal do outro. 2007. Tese (Doutorado em Teoria Literária e Literatura Comparada) - Faculdade de Filosofia, Letras e Ciências Humanas da Universidade de São Paulo, São Paulo, 2007. p. 55-56, nota 65).
} 
Minas. ${ }^{397}$ Mas a recomposição da casa de Mário, com seus prodígios e sua fraternidade acolhedora e crítica, não são observados apenas na relação Mário-Drummond, e sim no alto ideal de filia que fez Mário de Andrade ocupar uma posição central e germinadora no Modernismo brasileiro:

Todas as brisas da saudade balançam a casa, empurram a casa, navio de São Paulo no céu nacional, vai colhendo amigos de Minas e Rio Grande do Sul, gente de Pernambuco e Pará, todos os apertos de mão, todas as confidências a casa recolhe, embala, pastoreia.

Os que entram e os que saem se cruzam na imensidão dos corredores, paz nas escadas, calma nos vidros, e ela viaja como um lento pássaro, uma notícia postal, uma nuvem pejada. Casas ancoradas saúdam-na fraternas:

Vai, amiga!

\footnotetext{
397 Copio aqui, escolhidas como amostras, e não demonstração exaustiva, algumas observações de Drummond sobre a importância de Mário em sua vida e obra. Sobre o nacionalismo literário e a aceitação da vida, em carta de 6 de fevereiro de 1925: "Você, com duas ou três cartas valentes acabou o milagre. Converteu-me à terra. Creio agora que, sendo o mesmo, sou outro pela visão menos escura e mais amorosa das coisas que me rodeiam. Respiro com força. Berro um pouco. Disparo. Creio que sou feliz!" (SANTIAGO, Silviano (Org.). Carlos \& Mário. Correspondência de Carlos Drummond de Andrade e Mário de Andrade, cit., p. 95); sobre o casamento e a vida pessoal, em carta e 19 de julho de 1925: "Nenhuma palavra me comoveu tanto ao longo da minha aventura (porque foi uma aventura, e complicadíssima) como aquela de sua carta: 'Antes de ser artista, seja homem'" (Idem, p. 131), complementada por essas palavras de 6 de outubro de 1925: "Pode acreditar que associei o nome de você à ideia da minha felicidade doméstica, e que se não sou de todo uma peste de marido, em grande parte devo a você. [...] Você é para mim aquilo que o diabo da retórica já estragou: o anjo do lar. Sem o passadismo das duas asas brancas, acho que a imagem é boa e explica bem o papel realmente paternal que você desempenha na minha intimidade" (Idem, p. 145); como referência humana e literária, em carta de 18 de maio de 1930: "sempre procurei e encontrei em você o amigo mais forte, o disciplinador e o encorajador" (Idem, p. 375); além da orientação sobre o modo de relacionar o engajamento político e a posição e artista, como escreve Drummond em seu diário no dia 16 de fevereiro de 1945: "Carta de Mário de Andrade, infeliz com o que viu e ouviu no Congresso de Escritores em São Paulo. Concluiu que o destino do escritor há de ser a torre de marfim dentro da qual trabalhe - o que não quer dizer não-meimportismo nem artepurismo. Guardar e meditar suas palavras: 'O intelectual, o artista, pela sua natureza, pela sua definição mesma de não conformista, não pode perder a sua profissão, se duplicando na profissão de político. Ele pensa, meu Deus! e a sua verdade é irrecusável para ele. Qualquer concessão interessada pra ele, pra sua posição política, o desmoraliza, e qualquer combinação, qualquer concessão o infama. É da sua torre de marfim que ele deve combater, jogar desde o cuspe até o raio de Júpiter, incendiando cidades. Mas da sua torre. Ele pode sair da torre e ir botar uma bomba no Vaticano, na Casa Branca, no Catete, em Meca. Mas sua torre não poderá ter nunca pontes nem subterrâneos.'//No meio de tantas paixões fáceis e tanta intelectualidade abdicante, Mário preserva o seu individualismo consciente, que lhe dá mais força para exercer uma ação social que os intelectuais-políticos praticam de mau jeito e sem resultado" (ANDRADE, Carlos Drummond de. O observador no escritório. Prosa seleta. Rio de Janeiro: Nova Aguilar, 2003. p. 973).
} 
Não te vás, amiga...

(Um homem se dá no Brasil mas conserva-se intato,

preso a uma casa e dócil a seus companheiros

esparsos.)

Parte IV (versos 20-36)

Com uma imagem surrealista, Drummond faz a casa de Mário despegar-se do chão e alçar voo no ar como um barco aéreo: "navio de São Paulo no céu nacional”. O processo metamórfico tem uma intenção totalizante, pois une o mundo das águas ("navio"), o mundo da terra ("casa") e o mundo do ar ("céu"). E esse complexo de imagens prodigiosas, de matriz surrealista, deriva de uma consequência da morte do poeta: "as brisas da saudade". O fim da vida de Mário ativa no poema de Drummond novamente o ciclo dionisíaco morte-ressurreição, pois é da morte do poeta que surgem as brisas da saudade que alçam sua casa ao ar e definem a posição do poeta no Modernismo brasileiro. ${ }^{398}$ Seguindo o percurso surrealista, a casa colhe os amigos através do Brasil: todo o processo metonímico exprime uma conotação de acolhimento: "casa" por "o homem dentro da casa", "colher" como ato natural de aproveitar o que está maduro, verbo que se contrapõe, implicitamente, a outros que conotariam alguma violência, como "ceifar" ou "arrebatar", e "amigos" por intelectuais, pintores, poetas, romancistas ou qualquer pessoa que se interessasse pela vida mental do momento presente. Por ser, então, Mário de Andrade um homem cujos prodígios comportam, por um lado, o alto ideal fraterno da filia e, por outro, a mais coerente organização intelectual do Modernismo brasileiro, ele exerce uma precedência isenta de violência: "todas as confidências a casa recolhe,/embala, pastoreia". E a calma da casa acolhedora é descrita em seus corredores, escadas, vidros, em sua qualidade de "lento pássaro", carta ("notícia postal"), "nuvem pejada", que passa saudando as casas "ancoradas". Num parêntese, que muda ligeiramente o tom da estrofe, sem cortar a sua fluência, Drummond muda o foco das metamorfoses surrealistas para a descrição de um processo subjetivo de Mário: sua capacidade simultânea de doação e autopertencimento, de enraizar-se em uma casa e estar espalhado por seus companheiros esparsos.

\footnotetext{
398 "Em sua dissolução, tudo o que é humano torna-se manifestação visível, e o que é mítico remanesce apenas como essência" (BENJAMIN, Walter. As Afinidades eletivas de Goethe. Ensaios reunidos: escritos sobre Goethe. São Paulo: Duas Cidades/Editora 34, 2009. p. 22).
} 
Seguindo o processo de perda e reaparição de Mário, de morte real e ressurreição mítico-dionisíaca no plano da poesia, à imagem surrealista da casa-navio voador se sucede novamente a consciência do corpo do morto, da dor da perda:

\author{
Súbito a barba deixou de crescer. Telegramas \\ irrompem. Telefones \\ retinem. Silêncio \\ em Lopes Chaves.
}

Agora percebo que estamos amputados e frios.

Não tenho voz de queixa pessoal, não sou

um homem destroçado vagueando na praia.

Muitos procuram São Paulo no ar e se concentram,

aura secreta na respiração da cidade.

É um retrato, somente um retrato,

algo nos jornais, na lembrança,

o dia estragado, como uma fruta,

um véu baixando, um ríctus,

o desejo de não conversar. É sobretudo a pausa oca

e além de todo o vinagre.

Parte IV (versos 37-51)

A primeira estrofe citada é composta de versos curtos e abruptos, depois da primeira frase do primeiro verso. Os enjambements de certa forma despedaçam os versos, criando um ambiente de ruídos sem sentido e silêncio seco. Do aparecimento luminoso do poeta em sua casa-navio voador, retornamos ao sujeito lírico de Drummond, sentindo de início a mutilação coletiva da perda de Mário e, em seguida, ressentindo subjetivamente a morte. Com exceção do enjambement do segundo para o terceiro verso da segunda estrofe citada, os demais versos são juízos inteiros, cada vez mais secos e sentidos, em que o poeta, na imagem final da "pausa oca/e além de todo vinagre", retorna ao estado "rigorosamente noturno, vazio" da parte II do poema. Passando à última estrofe do poema, citada a seguir, podemos captar o ritmo cíclico do poema, composto de uma sequência de ciclos dionisíacos de morte-ressurreição. Dessa situação "rigorosamente noturna", em "pausa oca”, na última estrofe, Mário retorna pela última vez no poema: 
Mas tua sombra robusta desprende-se e avança.

Desce o rio, penetra os túneis seculares

Onde o amigo marcou seus traços funerários

Desliza na água salobra, e ficam tuas palavras

(superamos a morte, a palma triunfa)

tuas palavras-carbúnculo e carinhosos diamantes.

Parte IV (versos 52-57)

O poder mítico do ciclo dionisíaco é aqui descrito literalmente: ao descer o rio da morte, as palavras que permanecem revivem o poeta: "superamos a morte, a palma triunfa". O fato de ficarem as palavras dá a medida de que é essencialmente o poeta que Drummond está revivendo, poeta que é também um correspondente e um homem de pensamento, cuja essência final é a palavra em seu estado mais precioso: a poesia. $\mathrm{O}$ verso final, com suas "palavras-carbúnculo e carinhosos diamantes", merece particular atenção. A palavra "carbúnculo", em "estado de dicionário", significa: 1. Pedra de cor avermelhada, abrasiva; 2. Doença: infecção extensa profunda da pele e dos tecidos subjacentes; e etimologicamente: carvãozinho, pedra preciosa, areia vermelha, enfermidade. ${ }^{399}$ A pluralidade de significações, principalmente de acordo com sua etimologia, consegue apreender com muita perspicácia a própria multiplicidade da obra poética de Mário de Andrade. Deve-se notar que cada um dos significados de "carbúnculo" traz em si uma face da poesia mariodeandradiana: carvãozinho, pedra preciosa e areia vermelha são significados que se ligam ao modo como Mário concebe a natureza sacrificial de sua obra, o "incêndio puro do amor", como diz em "A Meditação sobre o Tietê": "Porque os meus gestos e os meus ritmos nascem/Do incêndio puro do amor..." (versos 288-289). ${ }^{400}$ São faces do processo incendiário: a areia vermelha, a pedra preciosa avermelhada, abrasiva, e a consequência do processo, os carvõezinhos. A essa face sacrificial, "carbúnculo" contém outro aspecto fundamental: a infecção, o contágio. Não somente as águas do Tietê são as águas imundas do contágio mas também a vítima sacrificial precisa sujar-se com as doenças da comunidade, para eliminar dela a violência, o que unifica as posições de vítima sacrificial e bode

\footnotetext{
${ }^{399}$ HOUAISS, Antônio; VILLAR, Mauro de Salles; FRANCO, Francisco Manoel de Mello. Dicionário Houaiss da língua portuguesa. Rio de Janeiro: Objetiva, 2007. p. 621.

400 "Só existe uma virtude, com que a Fé se confunde, é Charitas, vermelha, incendiada de amor" (ANDRADE, Mário de. O banquete. Belo Horizonte: Itatiaia, 2004. p. 63).
} 
expiatório. ${ }^{401} \mathrm{Com}$ as águas sujas do Tietê e a relação vítima sacrificial-bode expiatório, ainda estamos no plano da especulação (embora não seja sem fundamento, espero), pois não sabemos se Drummond leu a grande "Meditação" até esse momento nem se realmente intuiu a relação entre sacrifício e contenção da violência contagiosa. O que sabemos é que Drummond sempre notou na poesia do amigo uma presença constante de elementos não poéticos, elementos da vida e do pensamento que Mário, "alma apostólica" (sem ironia), teria urgência em comunicar. ${ }^{402}$ Como se Mário contaminasse a pureza da poesia com a impureza da vida. ${ }^{403}$ "Palavras-carbúnculo" são, então, próprias de uma poesia infectada com a impureza da vida, mas purificadas pelo incêndio sacrificial do amor, incêndio do qual essas palavras trazem os resíduos de areia vermelha, pedra preciosa abrasada e carvãozinho. Como o famoso “áporo", "carbúnculo" também é uma palavra-processo, uma palavra que capta a natureza da obra poética de Mário de Andrade como processo e movimento. Mas, uma vez encerrado o processo, com a morte do amigo ("súbito a barba parou de crescer"), ${ }^{404} \mathrm{o}$ resultado do complexo dionisíaco-sacrificial de morte-ressurreição se completa e ficam os "carinhosos diamantes", que é a imagem da obra poética de Mário concebida em seu conjunto e coerência. Nesses versos finais: “... e ficam tuas palavras/(superamos a

\footnotetext{
401 "Todos os rancores espalhados por mil indivíduos diferentes, todos os ódios divergentes, vão daí por diante convergir para um indivíduo único, a vítima emissária" [grifo do original] (GIRARD, René. La violence et le sacré. Paris: Hachette, 1972. p. 122). O capítulo de Girard fala especificamente sobre Édipo ("Édipo e a vítima emissária") e seu papel sacrificial. A expressão "bode expiatório" é usada algumas páginas antes da citação feita acima: "Seu papel [de Édipo] é o de um verdadeiro bode expiatório humano" [tradução livre] (p. 119).

${ }^{402}$ Como diz Drummond em carta de $1^{\circ}$ de janeiro de 1931: "Você me parece ceder por vezes à ânsia de comunicar coisas urgentes que estão passando no seu íntimo e que não são propriamente poesia. Coisas que dariam provavelmente um discurso... Em suma, você é muito universal demais para ser apenas poeta e há porções respeitáveis do seu ser que reagem contra a poesia no instante mesmo em que ela está se elaborando. Eu considero a poesia uma limitação, boa ou má não vem ao caso, e a linguagem em que é menos fácil aos homens se comunicarem, porque é a linguagem que poucos falam e mesmo esses não a possuem permanentemente. E você, alma apostólica (perdoe o adjetivo pois não acho outro), coração numerosíssimo e transbordante de humana ternura, tem tanto que comunicar aos outros! É natural que sua linguagem seja às vezes um pouco turva e inquieta" (SANTIAGO, Silviano (Org.). Carlos \& Mário. Correspondência de Carlos Drummond de Andrade e Mário de Andrade, cit., p. 401). Ver no Capítulo IV o contexto dessa passagem.

${ }^{403}$ É interessante lembrar que Mário chamava a poesia de Drummond e Bandeira de "puro, sem mistura". Ver resenhas de Alguma poesia, de Drummond, e Libertinagem, de Bandeira: ANDRADE, Mário de. Puro, sem mistura. Diário Nacional. São Paulo, 22 de junho de 1930. Reproduzido em ANDRADE, Mário de. Táxi e crônicas no Diário Nacional. Belo Horizonte: Itatiaia, 2005. p. 179-180.

${ }^{404}$ Sobre esse verso, interessante notar a única coisa que Manuel Bandeira comentou sobre o poema: "A propósito do seu poema sobre o Mário (de Andrade)... A barba do cadáver cresce" (ANDRADE, Carlos Drummond de. O observador no escritório, cit., p. 979). Bandeira escreveu sobre a morte de Mário: "A Mário de Andrade, Ausente", publicado em Belo belo (1948). Nessa passagem do poema de Drummond está a única diferença considerável entre a primeira versão do poema e a última (consulta na edição da Nova Aguilar de 2002): na primeira versão: "Telefones/retinem. Silêncio da barba. Silêncio/em Lopes Chaves”. A parte grifada por mim foi excluída da última versão.
} 
morte, a palma triunfa)/tuas palavras-carbúnculo e carinhosos diamantes", Drummond capta o processo de destruição purificadora operada pela obra de Mário de Andrade, processo em que a superação da morte - ciclo dionisíaco - envolve palavras-carbúnculo purificadas em carinhosos diamantes. Esse processo de destruição purificadora unifica o esforço de reflexão poética e o entendimento poético do mundo que rege como estrutura profunda a variedade de formas de que se constitui a obra poética de Mário de Andrade e $A$ rosa do povo de Drummond. Desse modo, os processos de reflexão subjetiva e poética são tão importantes quanto a acumulação de processos técnicos e formais na constituição de um conjunto de obras poéticas coerentes, o que, no contexto aqui apresentado, configura um dos modos de formação da poesia modernista brasileira. Essa reflexão subjetiva e poética presente na obra dos poetas não deixa de ter enorme importância pelo fato de ser menos visível do que os procedimentos técnico-formais. ${ }^{405}$ Aliás, é da análise e interpretação conjunta e dialética de ambos - reflexão e técnica poética - que a crítica pode tirar seus melhores resultados. Enfim, a reflexão poética sobre a matéria histórica brasileira chegava à solução de que somente uma destruição purificadora, seja pelo ciclo dionisíaco morte-ressurreição, seja pelo processo expiaçãoressurgimento, seria capaz de libertar as potencialidades de vida livre da linguagem, da arte, da vida mental e da vida social. Essa solução poético-mítica se apresenta também como uma hermenêutica histórica e leva a uma politização necessária, a uma posição política dos poetas Mário e Drummond para a oposição, alinhando-os, mais por lógica poética do que por convicção política, à esquerda, e dando esses poetas coerência a uma série de poemas fundamentais, orientavam a poesia modernista brasileira em um sentido crítico e radical.

${ }^{405}$ Essa distinção pode ser aproximada ao que Walter Benjamin chama de "teor factual" e "teor de verdade" nas obras literárias (BENJAMIN, Walter. As Afinidades eletivas de Goethe, cit., p. 12-15). 
Passaram-se os vinte anos de "Mário de Andrade desce aos Infernos", e Drummond não fez o poema cantado com tal suspiro que as flores pasmariam e as abelhas, confundidas, esvairiam seu mel. Supor que essa hipérbole da primeira estrofe do poema era apenas uma figura de retórica para elogiar o amigo morto seria uma malícia desnecessária da parte do crítico. Drummond não deixou de escrever poemas sobre o amigo: em Claro enigma (1951) há “Aniversário", sobre os cinco anos da morte de Mário, e em Lição de coisas (1961) há "Mário Longínquo". Então, por que não há o prometido poema dos vinte anos? Uma inquirição mais atenta sobre as implicações estéticas, históricas e sociais de A rosa do povo pode, talvez, esclarecer a questão. Antes, uma pequena observação sobre a concepção de conjunto usual, por parte da crítica, da obra de Carlos Drummond de Andrade. Costuma-se estudar a transformação dos estilos da poesia de Drummond (suas "fases") tendo como pano de fundo uma história estática, como se os movimentos dessa poesia se criassem e evoluíssem autonomamente a partir de si mesmos. Contudo, essa transformação de estilos, coerente como é, tem de ser entendida como um diálogo, e os interlocutores fundamentais desse diálogo são a história da poesia brasileira (e europeia, mediada pela poesia brasileira) e a história social do Brasil (e do mundo, esta mediada pela história social do Brasil). É em relação aos momentos poéticos e históricos do Brasil que o estilo do poeta vai se transformando. Desse modo, a confiança social do poeta ocorre entre 1943 e 1945, com a nova poesia social brasileira e europeia (Mário de Andrade e a poesia social inglesa de Auden, por exemplo), com o enfraquecimento progressivo da ditadura estadonovista e com a expansão do Comunismo internacional na parte final da Segunda Guerra Mundial. Da interlocução com essa poesia e com esse estágio do processo histórico é que decorre a imantação dos significados e das elaborações poéticas de $A$ rosa do povo. Trata-se de um momento favorável para que a culpa histórica da inteligência brasileira seja expiada, e os sentidos libertários da nação sejam destravados. O mito do ciclo dionisíaco ou do processo expiação-ressurgimento é uma resposta de Drummond a esse diálogo; para isso, ele absorve o projeto poético e o sentido da obra poética de Mário de Andrade que, dionisicamente, morre e renasce em A rosa do povo. Os vinte anos entre "Mário de Andrade desce aos Infernos" e o poema prometido na primeira estrofe seriam um tempo de elaboração que dependia fundamentalmente do surgimento do mundo redimido com que trabalha o livro de Drummond de 1945. O poema seria germinado pelo trabalho do tempo livre, resultante, entre outras coisas, do sacrifício de Mário; 
assim, a nova geração redimida poderia ler o canto suspirado que deslumbraria a própria natureza. Mas, como se sabe, o rio da história brasileira não mudou o seu curso, e o rio Tietê, transformado em rio de asfalto, leva, em suas novas ondas de piche, mais essa flor nas auroras represadas para o peito dos sofrimentos dos homens. ${ }^{406}$

406 "Eu recuso a paciência, o boi morreu, eu recuso a esperança./Eu me acho tão cansado em meu furor./As águas apenas murmuram hostis, água vil mas turrona paulista/Que sobe e se espraia, levando as auroras represadas,/Para o peito dos sofrimentos dos homens" ("A Meditação sobre o Tietê", versos 322326). 


\section{BIBLIOGRAFIA UTILIZADA}

Edição utilizada das poesias de Mário de Andrade

ANDRADE, Mário de. Poesias completas. Edição crítica de Diléa Zanotto Manfio. Belo Horizonte: Itatiaia; São Paulo: Edusp, 1987.

Obras de Mário de Andrade

ANDRADE, Mário de. Amar, verbo intransitivo. Belo Horizonte/Rio de Janeiro: Villa Rica, 1995.

ANDRADE, Mário de. Aspectos da literatura brasileira. Belo Horizonte: Itatiaia, 2002.

ANDRADE, Mário de. Aspectos da música brasileira. Rio de Janeiro; Belo Horizonte: Villa Rica, 1991.

ANDRADE, Mário de. Aspectos das artes plásticas no Brasil. Belo Horizonte: Itatiaia, 1984.

ANDRADE, Mário de. Contos de Belazarte. São Paulo: Círculo do Livro, s/d.

ANDRADE, Mário de. Contos novos. São Paulo: Oesp Gráfica, 1997.

ANDRADE, Mário de. Convalescença. Revista do Brasil, n. 92, ago. 1923.

ANDRADE, Mário de. Danças dramáticas do Brasil. São Paulo: Livraria Martins, s/d.

ANDRADE, Mário de. Ensaio sobre a música brasileira. São Paulo: Livraria Martins, 1962.

ANDRADE, Mário de. Entrevistas e depoimentos. Organização de Telê Porto Ancona Lopez. São Paulo: T.A. Queiroz, 1983.

ANDRADE, Mário de. Introdução à estética musical. Organização de Flávia Camargo Toni. São Paulo: Hucitec, 1995.

ANDRADE, Mário de. Macunaíma. O herói sem nenhum caráter. São Paulo: Martins, 1979.

ANDRADE, Mário de. Música de feitiçaria no Brasil. Belo Horizonte: Itatiaia, 1983.

ANDRADE, Mário de. Música, doce música. Belo Horizonte: Itatiaia, 2006.

ANDRADE, Mário de. O baile das quatro artes. Belo Horizonte, Itatiaia, 2005.

ANDRADE, Mário de. O banquete. Belo Horizonte: Itatiaia, 2004.

ANDRADE, Mário de. O empalhador de passarinho. Belo Horizonte: Itatiaia, 2002.

ANDRADE, Mário de. O turista aprendiz. Belo Horizonte: Itatiaia, 2002.

ANDRADE, Mário de. Obra imatura. Belo Horizonte: Itatiaia, 1980. 
ANDRADE, Mário de. Os filhos de Candinha. Belo Horizonte: Itatiaia, 2006.

ANDRADE, Mário de. Táxi e crônicas no Diário Nacional. Belo Horizonte: Itatiaia, 2005.

ANDRADE, Mário de. Vida literária. São Paulo: Hucitec/Edusp, 1993.

Correspondência

AMARAL, Aracy (Org.). Correspondência Mário de Andrade \& Tarsila do Amaral. São Paulo: Edusp/IEB, 2001.

ANDRADE, Mário de. Cartas de Mário de Andrade a Álvaro Lins. Rio de Janeiro: José Olympio, 1983.

FERNANDES, Lygia (Org.). 71 Cartas de Mário de Andrade. Rio de Janeiro: Livraria São José, s/d.

MORAES, Marco Antônio (Org.). Correspondência Mário de Andrade \& Manuel Bandeira. São Paulo: Edusp/IEB, 2001.

SANTIAGO, Silviano (Org.). Carlos \& Mário. Correspondência de Carlos Drummond de Andrade e Mário de Andrade. Rio de Janeiro: Bem-Te-Vi, 2002.

Obras sobre Mário de Andrade

ALMEIDA, Fernando Mendes de. Mário de Andrade. São Paulo: Conselho Estadual de Cultura, 1965.

ALVARENGA, Oneyda. Mário de Andrade, um pouco. Rio de Janeiro: José Olympio, 1974.

ANDRADE, Carlos Drummond de. Confissões de Minas [1944]. Prosa seleta. Rio de Janeiro: Nova Aguilar, 2002.

ANDRADE, Oswald de. O meu poeta futurista. Jornal do Comércio. São Paulo, 27 de maio de 1921. Apud BRITO, Mario da Silva. História do modernismo brasileiro. Rio de Janeiro: Civilização Brasileira, 1981. v. I - Antecedentes da Semana de Arte Moderna.

ATHAYDE, Tristão de. Mais vozes de perto. Estudos. Rio de Janeiro: Civilização, 1933. $5^{\text {a }}$ Série.

BANDEIRA, Manuel. Mário de Andrade [1922]. Crônicas inéditas. São Paulo: Cosac e Naify, 2008. v. 1. 
BANDEIRA, Manuel. Mário de Andrade [1931]. Crônicas da província do Brasil. São Paulo: Cosacnaify, 2007.

BANDEIRA, Manuel. Mário de Andrade e a questão da língua. De poetas e poesia. Rio de Janeiro: Livraria São José, 1957.

BANDEIRA, Manuel. Reservista poeta. Mário de Andrade: Losango Cáqui. Revista do Brasil, São Paulo, set. 1926. Republicado em: BANDEIRA, Manuel. Andorinha, andorinha. Rio de Janeiro: José Olympio, 1983.

BASTIDE, Roger. Mário de Andrade [1940]. Poetas do Brasil. São Paulo: Edusp/Duas Cidades, 1997.

CACASO (Antônio Carlos Brito). Não quero prosa. São Paulo: Editora da Unicamp; Rio de Janeiro: Editora da UFRJ, 1997.

CAMPOS, Haroldo de. Morfologia de Macunaíma. São Paulo: Perspectiva, 1973.

CANDIDO, Antonio. Lembrança de Mário de Andrade. Revista do Arquivo Municipal de São Paulo. Homenagem a Mário de Andrade. CVI, jan. 1946. Republicado em: CANDIDO, Antonio. Mário de Andrade. Poesias. Revista do Instituto de Estudos Brasileiros, n. 36. São Paulo: IEB, 1994. (Publicado originalmente na revista Clima. São Paulo, n. 8, jan. 1942.)

CANDIDO, Antonio. O observador no escritório. Rio de Janeiro: Ouro sobre Azul, 2008 .

CANDIDO, Antonio. O poeta itinerante. O discurso e a cidade. São Paulo: Duas Cidades, 1998.

CARONE, Edgard. A segunda República (1930-1937). São Paulo: Difel, 1974.

CARVALHO, Lilian Escorel. A revista francesa L'Esprit Nouveau na formação das ideias estéticas de Mário de Andrade. 2 v. 2008. Tese (Doutorado em Literatura Brasileira) - Faculdade de Filosofia, Letras e Ciências Humanas da Universidade de São Paulo, São Paulo, 2008.

CASTRO, Moacir Werneck de. Mário de Andrade: exílio no Rio. Rio de Janeiro: Rocco, 1989.

DANTAS, Vinícius. Desmanchando o naturalismo: capítulos obscuríssimos da crítica de Mário e Oswald. Novos estudos. São Paulo, n. 57, jul. 2000.

DANTAS, Vinícius. Entre “A Negra” e a Mata Virgem. Novos estudos. São Paulo, n. 45, jul. 1996. 
DASSIN, Joan. Política e poesia em Mário de Andrade. São Paulo: Duas Cidades, 1978.

FERNANDES, Florestan. Mário folclorista. Revista do Arquivo Municipal de São Paulo. Homenagem a Mário de Andrade. CVI, jan. 1946.

GÓES, Fernando. História da Paulicéia desvairada. Revista do Arquivo Municipal de São Paulo. Homenagem a Mário de Andrade. CVI, jan. 1946.

GREMBECKI, Maria Helena. Mário de Andrade e L'Esprit nouveau. São Paulo: IEB, 1969.

IVO, Ledo. Lição de Mário de Andrade [1952]. Poesia observada. São Paulo: Duas Cidades, 1978.

KNOLL, Victor. Paciente arlequinada. Esboço de uma hermenêutica do imaginário na obra poética de Mário de Andrade. São Paulo: Hucitec, 1983.

LAFETÁ, João Luiz. 1930: a crítica e o modernismo. São Paulo: Duas Cidades/Editora $34,2000$.

LAFETÁ, João Luiz. A dimensão da noite. São Paulo: Duas Cidades/Editora 34, 2004.

LAFETÁ, João Luiz. Figuração da intimidade. São Paulo: Martins Fontes, 1986.

LIMA, Luiz Costa. Lira e antilira (Mário, Drummond, Cabral) [1968]. Rio de Janeiro: Topbooks, 1995.

LINS, Álvaro. Jornal de crítica. Rio de Janeiro: José Olympio, 1943. $2^{\text {a }}$ Série. Republicado em LINS, Álvaro. Os mortos de sobrecasaca. Rio de Janeiro: Civilização Brasileira, 1963.

LOPEZ, Telê Porto Ancona. Mário de Andrade: ramais e caminho. São Paulo: Duas Cidades, 1972.

LOPEZ, Telê Porto Ancona. Mariodeandradiando. São Paulo: Hucitec, 1996.

MACHADO FILHO, Aires da Mata. Crítica de estilos. Rio de Janeiro: Agir, 1956.

MAJOR NETO, José Emílio. A Lira Paulistana de Mário de Andrade: a insuficiência fatal do outro. 2007. Tese (Doutorado em Teoria Literária e Literatura Comparada) Faculdade de Filosofia, Letras e Ciências Humanas da Universidade de São Paulo, São Paulo, 2007.

MILLIET, Sérgio. O poeta Mário de Andrade. Revista do Arquivo Municipal de São Paulo. Homenagem a Mário de Andrade. CVI, jan. 1946.

PAES, José Paulo. Sobre "O Carro da Miséria”. Revista do Instituto de Estudos Brasileiros, n. 36. São Paulo: IEB, 1994. 
PAULA, Rosângela Asche de. O expressionismo na biblioteca de Mário de Andrade: da leitura à criação. 2007. Tese (Doutorado em Literatura Brasileira) - Faculdade de Filosofia, Letras e Ciências Humanas da Universidade de São Paulo, São Paulo, 2007. PINTO, Edith Pimentel. A gramatiquinha da fala brasileira. São Paulo: Duas Cidades, 1990.

RIBEIRO, João. O Clã do Jaboti [1928]. Os modernos. Rio de Janeiro: Academia Brasileira de Letras, 1952.

ROSENFELD, Anatol. Mário e o cabotinismo. Texto/Contexto. São Paulo: Perspectiva, 1969.

SCHWARZ, Roberto. O psicologismo da poética de Mário de Andrade. A sereia e o desconfiado. Rio de Janeiro: Civilização Brasileira, 1965.

SCHWARZ, Roberto. Outra Capitu. Duas meninas. São Paulo: Companhia das Letras, 1997.

SOUZA, Gilda de Mello e. A poesia de Mário de Andrade [1988]. A ideia e o figurado. São Paulo: Duas Cidades/ Editora 34, 2005.

SOUZA, Gilda de Mello e. O tupi e o alaúde [1979]. São Paulo: Duas Cidades/Editora 34, 2003.

SOUZA, Gilda de Mello e; SOUZA, Antonio Candido de Mello e. A Lembrança que Guardo de Mário. Revista do Instituto de Estudos Brasileiros. n. 36, São Paulo: IEB, 1994.

VITOR, Nestor. Mário de Andrade [1928]. Os de hoje. São Paulo: Cultura Moderna, 1938.

Revistas modernistas

ANDRADE, Carlos Drummond de; MOURA, Emílio; ALMEIDA, Martins de; CANEDO, Gregoriano. A Revista. Belo Horizonte, 1925/1926. Edição fac-similar. São Paulo: Metal Leve, 1978.

BRITO, Mário da Silva (Org.). KLAXON - mensário de Arte moderna. Edição facsimilar (1922-23). São Paulo: Livraria Martins, 1972.

ESTÉTICA 1924/1925. Edição fac-similar. Rio de Janeiro: Gernasa, 1974.

Obras sobre o Modernismo

ATHAYDE, Tristão de. Estudos. Rio de Janeiro: A Ordem, 1927. 1ª Série. 
BATISTA, Marta Rossetti; LOPEZ, Telê Porto Ancona; LIMA, Yone Soares de. Brasil: $1^{\circ}$ tempo modernista-1917/1929. Documentação. São Paulo: IEB, 1972.

BRITO, Mário da Silva. História do modernismo brasileiro. Rio de Janeiro: Civilização Brasileira, 1997.

CARVALHO, Sérgio de. O drama impossível. O teatro modernista de Antônio de Alcântara Machado, Oswald de Andrade e Mário de Andrade. 2002. Tese (Doutorado em Literatura Brasileira) - Faculdade de Filosofia, Letras e Ciências Humanas da Universidade de São Paulo, São Paulo, 2002.

DANTAS, Vinícius. Oswald de Andrade e a Poesia. Novos estudos. São Paulo, n. 30, jul. 1991.

EULALIO. Alexandre. A aventura brasileira de Blaise Cendrars: ensaio, cronologia, filme, depoimento, antologia, desenhos, conferências, correspondência, traduções. 2. ed. rev. e ampl. por Carlos Augusto Calil. São Paulo: Edusp/Fapesp, 2001.

GOLDSTEIN, Norma. Do Penumbrismo ao Modernismo: o primeiro Bandeira e outros poetas significativos. São Paulo: Ática, 1983.

LEITE, Ligia Chiappini Moraes. Modernismo no Rio Grande do Sul. Materiais para o seu estudo. São Paulo: IEB, 1972.

RAMOS, Péricles Eugênio da Silva. O Modernismo na poesia. COUTINHO, Afrânio (Org.). A literatura no Brasil. Era modernista. São Paulo: Global, 2004. v. V.

RAMOS, Péricles Eugênio da Silva. Poesia moderna. São Paulo: Melhoramentos, 1967.

Geral

ADORNO, Theodor W. Notas de literatura I. São Paulo: Duas Cidades/Editora 34, 2003.

ADORNO, Theodor W. Teoria estética. Lisboa: Edições 70, 2008.

ADORNO, Theodor W.; HORKHEIMER, Max. Dialética do esclarecimento. Rio de Janeiro: Jorge Zahar, 1985.

ALI, Manoel Said. Versificação portuguesa. São Paulo: Edusp, 1999.

ALMEIDA, Jorge de. Crítica dialética em Theodor Adorno. Música e verdade nos anos vinte. São Paulo: Ateliê, 2007.

ANDRADE, Carlos Drummond de. O observador no escritório. Prosa seleta. Rio de Janeiro: Nova Aguilar, 2003. 
ARANHA, Luís. Cocktails. Organização de Nelson Ascher e Rui Moreira Leite. São Paulo: Brasiliense, 1989.

ARANTES, Otília; ARANTES, Paulo. Sentido da formação. Três estudos sobre Antonio Candido, Gilda de Mello e Souza e Lúcio Costa. São Paulo: Paz e Terra, 1997. BASTIDE, Roger. Brasil: terra de contrastes. São Paulo: Difel, 1973.

BENJAMIN, Walter. As Afinidades eletivas de Goethe. Ensaios reunidos: escritos sobre Goethe. São Paulo: Duas Cidades/Editora 34, 2009.

BENJAMIN, Walter. Sobre o conceito de história. Magia e técnica, arte e política. Ensaios sobre literatura e história da cultura. São Paulo: Brasiliense, 1986.

BILAC, Olavo; PASSOS, Guimarães. Tratado de versificação. Rio de Janeiro: Livraria Francisco Alves, 1944.

BOSI, Alfredo. História concisa da literatura brasileira. São Paulo: Cultrix, 1999.

CAMILO, Vagner. Drummond: da rosa do povo à rosa das trevas. São Paulo: Ateliê Editorial, 2001.

CANDIDO, Antonio. Formação da literatura brasileira. Belo Horizonte: Itatiaia; São Paulo: Edusp, 1975. 2 v.

CANDIDO, Antonio. Literatura e sociedade. Rio de Janeiro: Ouro sobre Azul, 2008.

CANDIDO, Antonio. O discurso e a cidade. São Paulo: Duas Cidades, 1998.

CARPEAUX, Otto Maria. História da literatura ocidental. Rio de Janeiro: Edições O Cruzeiro, 1961. v. I-A.

CARPEAUX, Otto Maria. História da literatura ocidental. Rio de Janeiro: Edições O Cruzeiro, 1961. v. IV.

CASCUDO, Câmara. Dicionário do folclore brasileiro. Rio de Janeiro: Ediouro, s/d. COUTINHO, Afrânio (Org.). A literatura no Brasil. São Paulo: Global, 2004. v. V Era modernista.

DAMATTA, Roberto. Sabe com quem está falando? Um ensaio sobre a distinção entre indivíduo e pessoa no Brasil. Carnavais, malandros e heróis. Rio de Janeiro: Rocco, 1997.

DUTRA, Pedro. A literatura jurídica no Império. Rio de Janeiro: Padma, 2004.

ELIADE, Mircea. Mito e realidade. São Paulo: Perspectiva, 1972.

FÉLIX, Moacyr (Org.). Violão de rua. Rio de Janeiro: Civilização Brasileira, 1962. 3 v. (Cadernos do povo brasileiro). 
FERNANDES, Florestan. Questões preliminares de importância interpretativa. A revolução burguesa no Brasil. São Paulo: Globo, 2006.

FREUD, Sigmund. Três ensaios sobre a teoria da sexualidade. Obras completas. Rio de Janeiro: Imago, 1969. v. VII.

FREUD, Sigmund. Psicologia do amor. Obras completas. Rio de Janeiro: Imago, 1972. v. XI.

FREUD, Sigmund. Psicologia de grupo e análise do ego. Obras completas. Rio de Janeiro: Imago, 1969. v. XVIII.

FREYRE, Gilberto. Casa-grande \& senzala: introdução à história da sociedade patriarcal no Brasil. Rio de Janeiro: Record, 2000.

GIRARD, René. La violence et le sacré. Paris: Hachette, 1972.

GLEDSON, John. Poesia e poética de Carlos Drummond de Andrade. São Paulo: Duas Cidades, 1981.

GLEDSON, John. Influências e impasses. Drummond e alguns contemporâneos. São Paulo: Companhia das Letras, 2003.

GOES, Fernando. Panorama da poesia brasileira. Rio de Janeiro: Editora Civilização Brasileira, 1960. v. V - O Pré-modernismo.

HAMBURGUER, Michael. A verdade da poesia: tensões na poesia modernista desde Baudelaire. São Paulo: Cosac Naify, 2007.

HEGEL, G. W. Friedrich. A poesia lírica. Estética. Lisboa: Guimarães Editores, 1993.

HEGEL, G. W. Friedrich. Fenomenologia do espírito. Petrópolis: Vozes, 2000. 2 v.

HOLANDA, Sérgio Buarque. Raízes do Brasil. São Paulo: Companhia das Letras, 1995.

HOUAISS, Antônio; VILLAR, Mauro de Salles; FRANCO, Francisco Manoel de Mello. Dicionário Houaiss da língua portuguesa. Rio de Janeiro: Objetiva, 2007.

LUKÁCS, Georg. História e consciência de classe. Estudos sobre a dialética marxista. São Paulo: Martins Fontes, 2003.

MASSI, Augusto (Org.). Artes e ofícios da poesia. Porto Alegre: Artes e Ofícios, 1991.

MEYER, Augusto. Poesias 1922-1955. Rio de Janeiro: Livraria São José, 1957.

MICELI, Sérgio. Intelectuais e classe dirigente no Brasil (1922-1945). São Paulo: Difel, 1979.

MICELI, Sérgio. A elite eclesiástica brasileira: 1890-1930. São Paulo: Companhia das Letras, 2009. 
MORAIS FILHO, Evaristo. O problema do sindicato único no Brasil: seus fundamentos sociológicos. São Paulo: Alfa-Omega, 1978.

NAVES, Rodrigo. Anonimato e singularidade em Volpi. A forma difícil. Ensaios sobre arte brasileira. São Paulo: Editora Ática, 2001.

NIETSZCHE, Friedrich. O nascimento da tragédia ou helenismo e pessimismo. São Paulo: Companhia das Letras, 2007.

OEHLER, Dolf. Quadros parisienses. São Paulo: Companhia das Letras, 1997.

OITICICA, José. Sonetos. 2a Série (1911-1918). Maceió: Linotypia da Casa Ramalho, 1919.

PASTA JR., José Antônio. Changement et idée fixe (l'autre dans le roman brésilien).

Cahier. Centre de Recherche sur les Pays Lusophones (Crepal), Paris, 2003.

PASTA JR., José Antônio. La singularité du double au Brésil. In: La clinique du speculaire dans l'oeuvre de Machado de Assis. Paris: Association Lacanienne Internationale, 2003.

PASTA JR., José Antônio. Le point de vue de la mort (une structure récurrente de la culture brésilienne). In: PENJON, Jacqueline (Org.). Voies du paysage. Representations $d u$ monde lusophone. Cahier 14 du Centre de Recherche sur les Pays Lusophones (Crepal). Paris: Presses Sorbonne Nouvelle, 2006.

PASTA JR., José Antônio. Pompéia: a metafísica ruinosa d'O Ateneu. 1990. Tese (Doutorado em Literatura Brasileira) - Faculdade de Filosofia, Letras e Ciências Humanas da Universidade de São Paulo, 1990.

PASTA JR., José Antônio. Tristes estrelas da Ursa. Macunaíma. In: AVANCINI, José Augusto; SILVA, Márcia Ivana de Lima e. Cadernos ponto \& vírgula, n. 4. Porto Alegre: Secretaria Municipal de Cultura, 1993.

PASTA JR., José Antônio. Volubilidade e ideia fixa (o outro no romance brasileiro). Tradução do original francês de Cláudio R. Duarte. Sinal de menos, ano 2, n. 4, 2010. Disponível em: <http://www.sinaldemenos.org>.

PASTA JR., José Antônio; PENJON, Jacqueline. Le rythme singulier d'une formation historique. In: PASTA JR., José Antônio; PENJON, Jacqueline (Org.). Littérature et modernisation au Brésil. Paris: Presses Sorbonne Nouvelle, 2004.

RICUPERO, Bernardo. Caio Prado Jr. e a nacionalização do marxismo no Brasil. São Paulo: Departamento de Ciência Política da Universidade de São Paulo; Fapesp; Editora $34,2000$. 
RICUPERO, Bernardo. Sete lições sobre as interpretações do Brasil. São Paulo: Alameda, 2008.

RODAPÉ - Crítica da literatura brasileira contemporânea. São Paulo: Nankin, n. 3, nov. 2004.

ROMERO, Sílvio. História da literatura brasileira. Rio de Janeiro: José Olympio, 1960. t. IV.

ROQUETTE-PINTO, Edgar. Rondônia. São Paulo: Companhia Editora Nacional, 1975.

SCHWARZ, Roberto. A poesia envenenada de Dom Casmurro. Duas meninas. São Paulo: Companhia das Letras, 1997.

SCHWARZ, Roberto. Ao vencedor as batatas. São Paulo: Duas Cidades/Editora 34, 2000.

SCHWARZ, Roberto. Que horas são? São Paulo: Companhia das Letras, 2006.

SCHWARZ, Roberto. Sequências brasileiras. São Paulo: Companhia das Letras, 1999.

SCHWARZ, Roberto. Um mestre da periferia do capitalismo. São Paulo, Duas Cidades/Editora 34, 1992.

SIMON, Iumna Maria. Considerações sobre a poesia brasileira em fim de século. Novos estudos. São Paulo, n. 55, nov. 1995.

SIMON, Iumna Maria. Drummond: uma poética do risco. São Paulo: Ática, 1978.

SPINA, Segismundo. A lírica trovadoresca. São Paulo: Edusp, 1996.

VALÉRY, Paul. Degas Dança Desenho. São Paulo: Cosac \& Naify, 2003.

VALÉRY, Paul. Oeuvres II. Paris: Gallimard, 1960.

WORDSWORTH, William. Preface to the second edition of several of the foregoing poems, published, with an additional volume, under the title of "Lyrical Ballads". The complete works of William Wordsworth. London: Macmillan and Co., 1905. 